\title{
2H-AZIRINEK ÚJ TÍPUSÚ REAKCIÓI
}

\author{
Doktori (Ph.D.) értekezés
}

\section{Angyal Anikó}

TÉMAVEZETÖK:

Dr. Kanizsai Iván Avidin Kft.

Prof. Dr. Wölfling János

tanszékvezetö egyetemi tanár

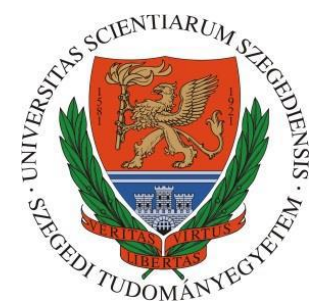

Szegedi Tudományegyetem

Természettudományi és Informatikai Kar

Szerves Kémiai Tanszék

SZTE Kémia Doktori Iskola

Szeged

2020 


\section{TARTALOMJEGYZÉK}

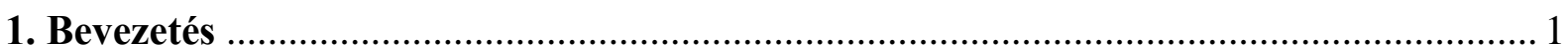

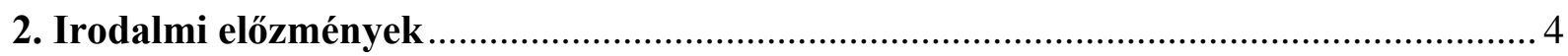

2.1. Ugi multikomponensü reakció..................................................................... 4

2.2. Ugi-Joullié háromkomponensű reakció ................................................................. 7

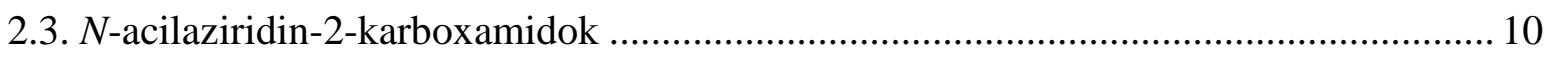

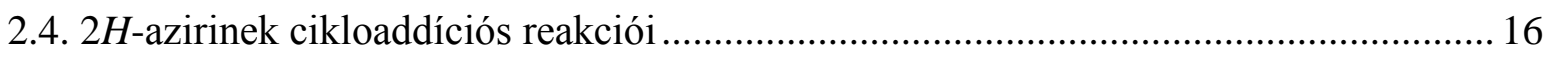

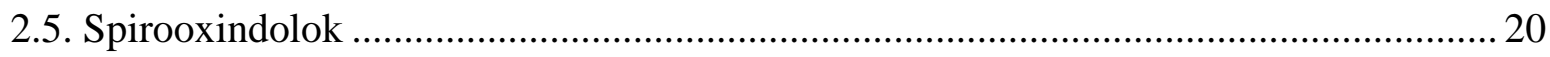

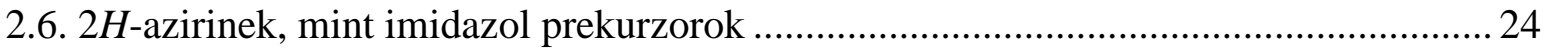

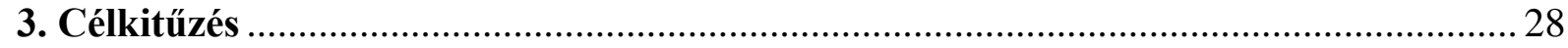

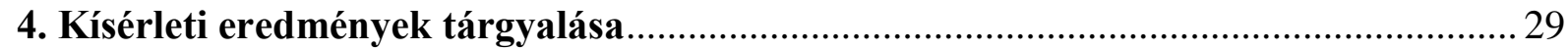

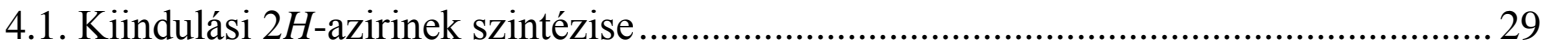

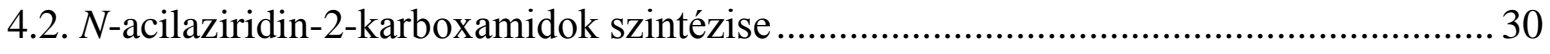

4.3. 1,3-diazaspiro[biciklo[3.1.0]hexán]oxindol vegyületek szintézise ........................... 45

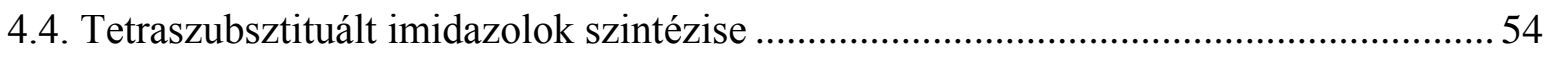

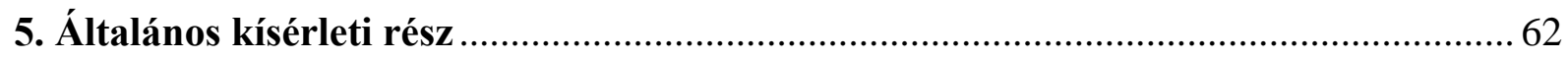

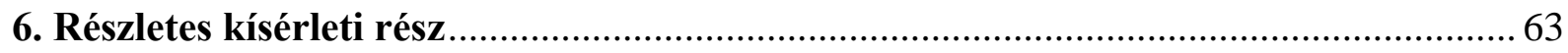

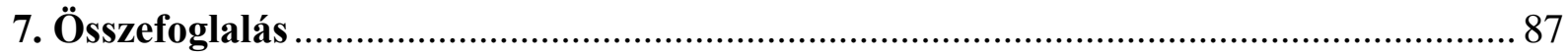

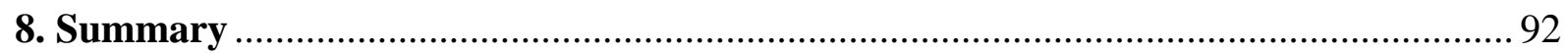

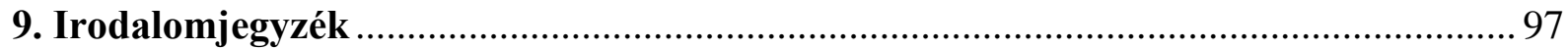

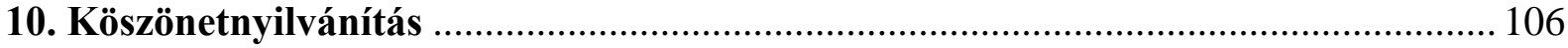

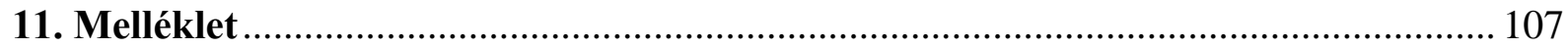




\section{RÖVIDÍTÉSEK JEGYZÉKE}

Boc

BOP

$\mathrm{Cbz}$

CDI

$\mathrm{Cp}$

DBU

DCC

DMA

DMAP

DNBA

EDC

EWG

HFIP

$\mathrm{HOBt}$

IPA

LA

MAO-N

MOM

MW

PG

PyBOP

PTSA

$\mathrm{rt}$

TBAF

TBHP

TEA

TFA

TIPS

TMS

Trt
terc-Butoxikarbonil

(Benztriazol-1-iloxi)-trisz-(dimetilamino)-foszfónium-hexafluor-foszfát

Benziloxikarbonil

$N, N$-karbonil-diimidazol

Ciklopentadienil

1,8-Diazabiciklo[5,4,0]undec-7-én

$N, N^{\prime}$-Diciklohexil-karbodiimid

$N, N$-dimetilacetamid

4-(Dimetilamino)-piridin

3,5-Dinitrobenzoesav

$N$-Etil- $N$ '-(3-dimetilaminopropil)-karbodiimid

Electron withdrawing group (elektronszívó csoport)

Hexafluor-izopropil-alkohol

1-Hidroxi-benzotriazol

Izopropil-alkohol

Lewis acid (Lewis-sav)

Monoamin-oxidáz N

Metoxi-metilén

Microwave (mikrohullám)

Protective group (védőcsoport)

(Benztriazol-1-iloxi)-tripirrolidin-foszfónium-hexafluor-foszfát $p$-Toluolszulfonsav

Room temperature (szobahőmérséklet)

Tetrabutil-ammónium-fluorid

terc-Butil-hidroperoxid

Trietilamin

Trifluorecetsav

Triizopropil-szililéter

Trimetilszilil

Trifenilmetil 


\section{Bevezetés}

A $2 H$-azirinek természetben ritkán, de előforduló stabil, háromtagú, telítetlen nitrogéntartalmú heterociklusos vegyületek. ${ }^{1,2}$ A gyürürendszer feszültségéből eredő jelentős mértékü reaktivitásuknak, valamint az ezzel összefüggő szerteágazó átalakítási lehetőségeiknek köszönhetően a szerves kémiai szintetikus eszköztár legértékesebb építőelemei közé tartoznak. ${ }^{3}$ Termikus vagy fotokémiai gerjesztéssel mindhárom kötés mentén szelektíven nyithatók, mely instabil vinilnitrén, iminokarbén vagy nitrililid intermediereket eredményez. Továbbá a nitrogénatom nemkötő elektronpárja által nukleofilként, a szénatomokon keresztül elektrofilként, az elektronban gazdag $\pi$-kötés kihasználásával cikloaddíciós reakciókban dienofilként és dipolarofilként egyaránt viselkedhetnek, lehetőséget kínálva számtalan változatos telített és telítetlen heterociklusos, illetve nyíltláncú vegyületek kialakítására (1. ábra). ${ }^{1-6}$

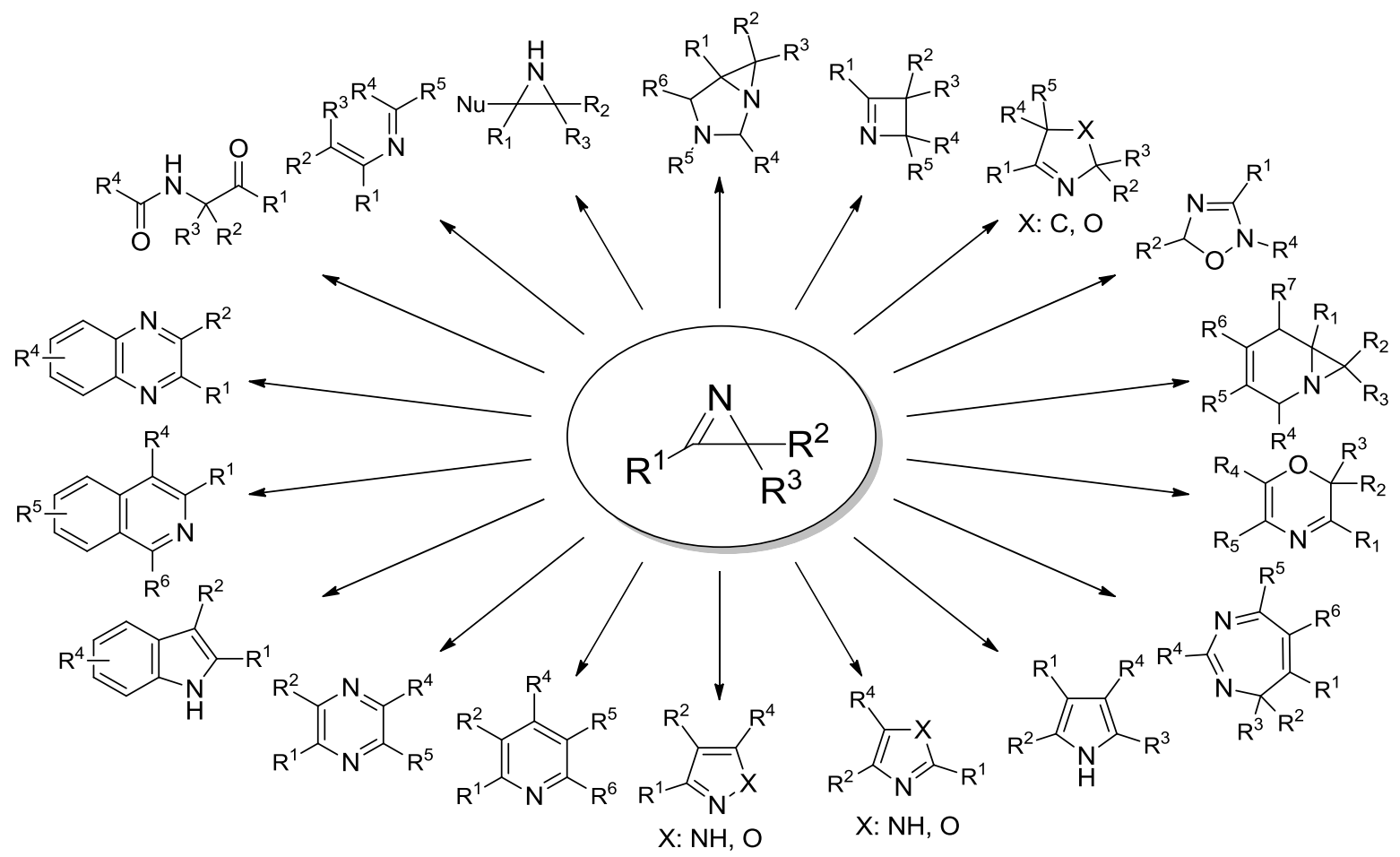

1. ábra. Néhány fontosabb, $2 H$-azirinből is elóállitható vázrendszer 
Telített származékai, az aziridinek előállítását hasonló élénk érdeklődés övezi, tekintve, hogy a különböző nukleofilekkel kiváló regio- és sztereokontroll mellett végbemenő gyürünyitási reakcióik révén számos aminszármazék, többek között $\alpha$-vagy $\beta$-aminosavak és aminoalkoholok királis prekurzoraiként szolgálnak. ${ }^{7-12}$ Emellett az utóbbi évtizedekben az aziridinek, mint tumorellenes és/vagy antibakteriális hatású végtermékek a gyógyszerkémiai kutatások fókuszába kerültek, mint számos kísérleti fázisban, illetve már klinikai alkalmazásban lévő szintetikus és természetes vegyület igazoltan farmakofór szerkezeti motívumai (2. ábra). ${ }^{13,14}$ A citotoxikus hatást alkilálószerként fejtik ki azáltal, hogy a humán vagy bakteriális DNS kettős lánca között keresztkötéseket létesítenek, mely apoptózishoz vezet.<smiles>S=P(C1CC1)(N1CC1)N1CC1</smiles>

Thiotepa<smiles>Cn1c(/C=C/CO)c(CO)c2c1C(=O)C=C(N1CC1)C2=O</smiles>

Apaziquone

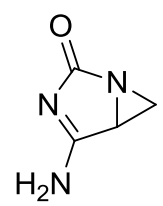

Imexon<smiles>NC(=O)c1cc(N2CC2)c([N+](=O)[O-])cc1[N+](=O)[O-]</smiles>

Tretazicar<smiles></smiles>

Mitomicin $A \quad R^{1}=\mathrm{OMe}, R^{2}=\mathrm{Me}, R^{3}=H$ Mitomicin $B \quad R^{1}=\mathrm{OMe}, R^{2}=H, R^{3}=\mathrm{Me}$ Mitomicin C $\quad R^{1}=\mathrm{NH}_{2}, R^{2}=\mathrm{Me}, \mathrm{R}^{3}=\mathrm{H}$ Porfiromicin $R^{1}=\mathrm{NH}_{2}, \mathrm{R}^{2}=\mathrm{Me}, \mathrm{R}^{3}=\mathrm{Me}$<smiles>[R]C(NC(=O)/C(NC(=O)[C@@H](OC(=O)c1cc(OC)cc2c(C)cccc12)[C@]1(C)CO1)=C1\[C@H](O)[C@H](O)[C@@H]2CN12)C(C)=O</smiles>

Azinomicin $A \quad R=H$ Azinomicin $B \quad R=C H O$

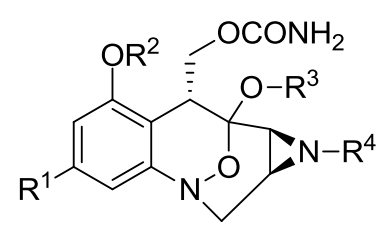

$F R-9000482 \quad R^{1}=C H O, R^{2}=R^{3}=R^{4}=H$ $F R$-66979 $\quad R^{1}=\mathrm{CH}_{2} \mathrm{OH}, R^{2}=R^{3}=R^{4}=H$ $F R-70496 \quad R^{1}=\mathrm{CHO}, R^{2}=\mathrm{Me}, R^{3}=H, R^{4}=A C$ FK-973 $\quad R^{1}=C H O, R^{2}=R^{3}=R^{4}=A C$

2. ábra. Biológiailag aktív természetes és szintetikus aziridin származékok

A szerves és gyógyszerkémiai kutatások egyik fő törekvése a nagy tagszámú és diverzitású molekulakönyvtárak hatékony felépítését kínáló módszerek fejlesztése. Ezen igénynek eleget téve az olyan sokoldalú prekurzorok, mint a $2 \mathrm{H}$-azirinek újfajta alkalmazási lehetőségeinek tanulmányozása - akár új aziridinvázas vegyületek vagy más biológiailag releváns, kiemelt jelentőségű heterociklusok szintézise céljából - ma is aktuális. 
A doktori disszertációmban a $2 H$-azirinek három, korábban ismeretlen átalakítását mutatom be (3. ábra);

(i) az Ugi-Joullié háromkomponensủ reakció $2 H$-azirinekre történő kiterjesztését, mellyel az $N$-acilaziridin-2-karboxamid vegyületcsalád egylépéses szintézise valósítható meg,

(ii) egy $2 H$-azirinek és izatinokból képzett azometin-ilidek 1,3-dipoláris cikloaddicióján (1,3-DC) alapuló háromkomponensü reakciót, mellyel egy új, aziridinnel kondenzált spirooxindol-imidazolidin vázrendszer alakítható ki, valamint

(iii) a $2 H$-azirinek és nitronok 1,3-dipoláris cikloaddiciós reakcióját, mely tetraszubsztituált imidazolok új megközelítésű szintézisét teszi lehetővé.

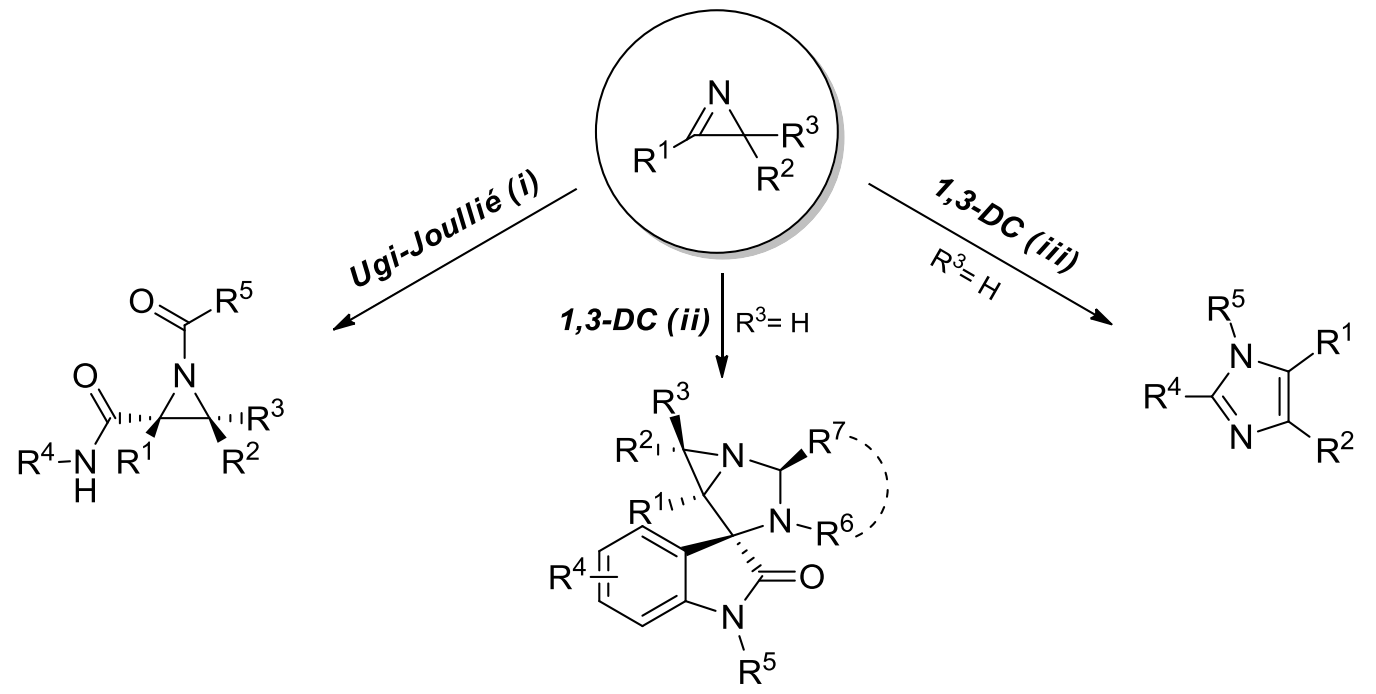

3. ábra. A $2 H$-azirinek doktori disszertációmban bemutatott új átalakításai 


\section{Irodalmi előzmények}

\subsection{Ugi multikomponensü reakció}

A multikomponensü reakciók (MCRs) olyan egyedényes eljárások, melyek három vagy több kiindulási komponens kaszkád reakcióján keresztül egy olyan új molekulát eredményeznek, melyben az összes kiindulási "építőelem" szerkezeti motívuma megtalálható. Ezen kombinatorikus szerves kémiai módszerek alkalmazásával lehetőség nyílik többlépéses, konvergens vagy lineáris szintézisek egy lépésben történő megvalósítására, nagy tagszámú, szerkezetileg komplex és diverz vegyületkönyvtárak rövid időn belüli létrehozására. ${ }^{15-18}$

Az izocianid alapú multikomponensü reakciók (I-MCRs) széles körben alkalmazott módszerek gyógyszerkémiailag releváns nyílt láncú és heterociklusos, természetes és mesterséges vegyületek szintézisére. ${ }^{19}$ Az egyik legintenzívebben tanulmányozott képviselője az Ugi négykomponensű reakció (Ugi-4CR, Ivar Ugi, 1959), ${ }^{20}$ mellyel 1 aldehidek, 2 aminok, 3 karbonsavak és 4 izocianidok kombinálásával az 5 -acilamino karboxamid származékok állíthatók elő egy új sztereogén centrum kialakulása közben (4. ábra). ${ }^{21}$ A reakció első lépésében a 6 imin képződik, melyet a 3 karbonsav aktivál. Az izocianid 7 imínium ionra történő addíciójából a 8 nitrílium köztitermék jön létre, mely a rendszerben lévő karboxilát anionnal stabilizálódva a 9 -adduktot eredményezi (A út). Végül intramolekuláris $1,4-(\mathrm{O} \rightarrow \mathrm{N})$ acilvándorlás (Mumm-átrendeződés) vezet az 5 termékhez. ${ }^{22}$ Megjegyzendő, hogy az imin elektrofil karakterének további növelésére Lewis-savak, például $\mathrm{TiCl}_{4}, \mathrm{Sc}(\mathrm{OTf})_{3}$ vagy $\mathrm{Yb}(\mathrm{OTf})_{3}$ is alkalmazhatók..$^{23,24}$ Egy alternatív reakciómechanizmus szerint a $\mathbf{7}$ imínium ionra

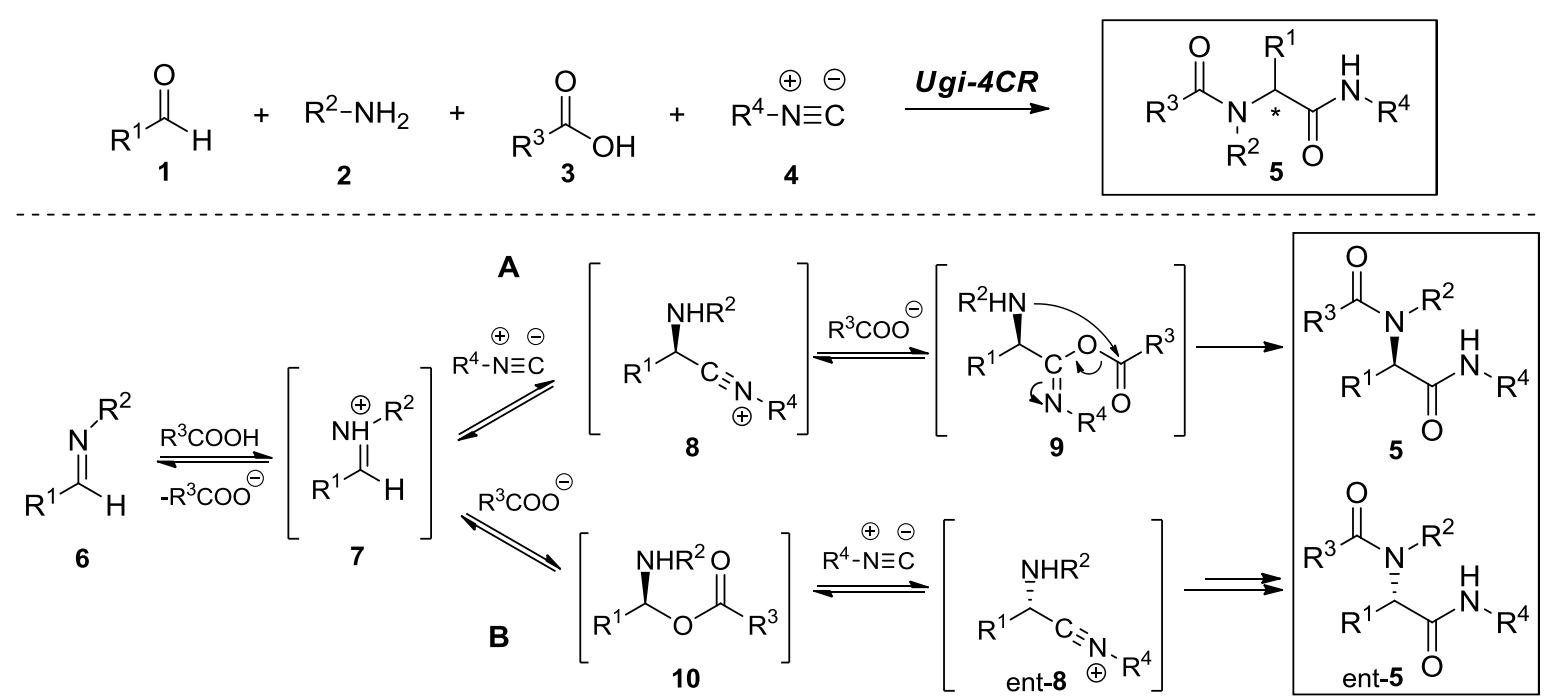

4. ábra. Az Ugi-4CR mechanizmusa 
a kevésbé térgátolt irányból a karboxilát anion is támadhat $\left(\mathbf{B}\right.$ út). ${ }^{25}$ Az így kialakuló $\mathbf{1 0}$ intermedier az izocianiddal $\mathrm{S}_{\mathrm{N}} 2$ mechanizmuson keresztül reagálva egy ellentétes konfigurációjú ent-8 nitríliumot eredményez, amely az előzőekben ismertetett reakciólépések révén az ent-5 terméket szolgáltatja.

Katalitikus enantioszelektív Ugi-4CR megvalósítására egyetlen példa ismert (2018). ${ }^{26} \mathrm{Az}$ újonnan kialakuló sztereogén centrum kontrollálását az ellentétes konfigurációjú végtermékhez vezető kompetitív $\mathbf{B}$ reakcióúton túl az imin sztereoszelektív aktiválása is nehezíti, mivel a katalizátor elektrofil centrumáért az imin mellett az erős komplexképző és nukleofil sajátságú amin komponens, valamint az Ugi-4CR által preferált poláris protikus oldószer is verseng. ${ }^{25,27}$ Ezzel szemben királis kiindulási komponensek alkalmazásával megvalósított diasztereoszelektív Ugi reakcióra több szakirodalmi példa található, azonban jelentős aszimmetrikus indukció csak királis aminokkal érhető el. ${ }^{15,21,28-30}$ Ugi $(S)$-1-fenetilamin és $(R)$-1-ferrocenil-etilamin felhasználásával az Ugi-4CR diasztereoszelektivitásának oldószer-, hőmérséklet- és koncentrációfüggését vizsgálta (5. ábra, A). A legnagyobb diasztereomer arányokat (dr) metanolban, $0{ }^{\circ} \mathrm{C}$-on, híg oldatban $(<0,05 \mathrm{M})$ érte el. ${ }^{31-34} \mathrm{Kunz}$ és kutatócsoportja királis komponensként galaktopiranozil-amin származékot vezetett be, melyet alacsony hőmérsékleten (-78 $\left.{ }^{\circ} \mathrm{C}, \mathrm{THF}\right), \mathrm{ZnCl}_{2}$ katalizátor jelenlétében, hangyasavval, alifás és aromás aldehidekkel és izocianidokkal kombinálva kiváló diasztereoszelektivitással állította elő a megfelelő $\mathbf{1 5}$ vegyületeket (5. ábra, B). ${ }^{35}$ Módszerük célja optikailag aktív $(R)$ - $\alpha$-aminosavak szintézise volt, melyet a 15 Ugi-termékek kétlépéses savas hidrolízisével - az $N$-glikozidos $\left(\mathrm{N}-\mathrm{R}^{1}\right)$ és az $N$ formil, majd az amid $\left(\mathrm{N}-\mathrm{R}^{4}\right)$ kötés hasadása révén - valósítottak meg. $N$-védett $\alpha$-aminosavak és $\alpha$-aminoészterek alkalmazásával dipeptidek nyerhetők (5. ábra, C). ${ }^{36}$ Érdekesség, hogy míg a diasztereoszelektivitást az $\alpha$-aminoészter oldallánca $\left(\mathrm{R}^{5}\right)$ nagymértékben befolyásolja, az aszimmetrikus indukcióhoz a királis savkomponens nem járul hozzá.

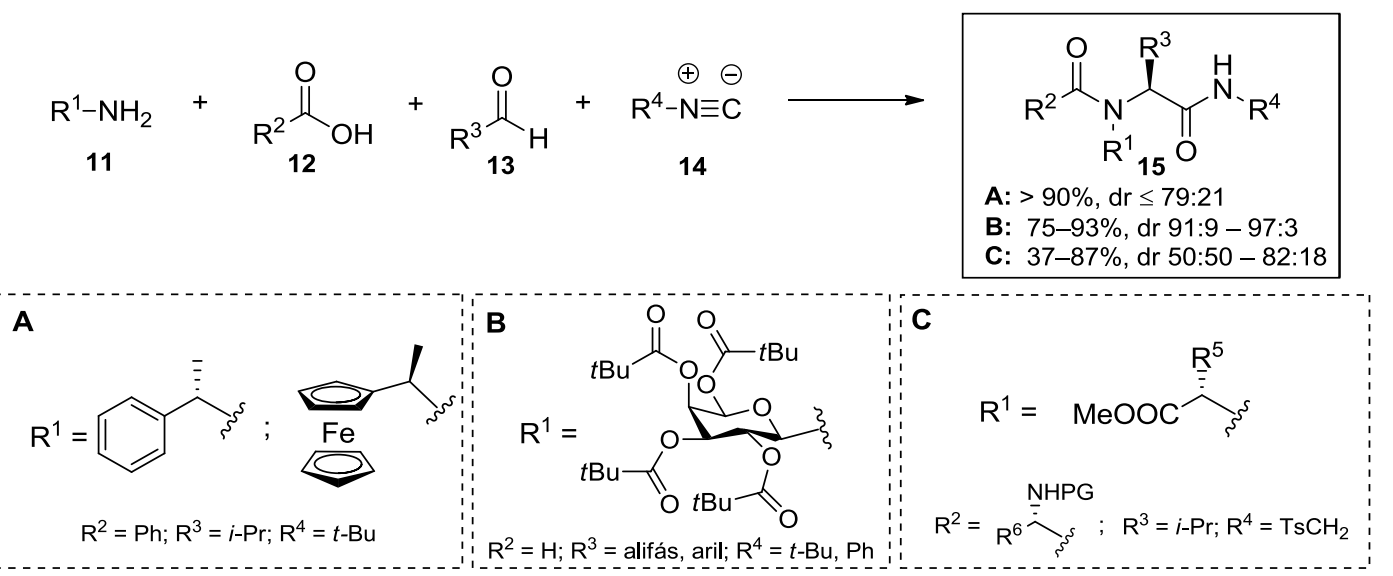

5. ábra. Diasztereoszelektív Ugi-4CR királis aminokkal 
Bifunkciós $\beta$-amino- vagy $\gamma$-keto-karbonsavból kiindulva - a nitrílium ion intramolekuláris stabilizációján alapulva - a klasszikus Ugi-reakció $\beta$ - és $\gamma$-laktámok diasztereoszelektív szintézisére is kiterjeszthető (Ugi-4C-3CR; Ugi négycentrumúháromkomponensü reakciók). Fülöp és kutatócsoportja a 16 di-exo oxanorbornén-vázas $\beta$ aminosavat különböző aldehidekkel és izocianidokkal reagáltatva a 21 triciklusos $\beta$-laktámokat állította elő (6. ábra). ${ }^{37} \mathrm{~A}$ feltételezett mechanizmus szerint a 19 nitrílium-ion intramolekuláris stabilizációját követően a héttagú 20 intermedier keletkezik, melyből Mumm-átrendeződéssel intramolekuláris gyürükontrakció vezet a $21 \beta$-laktámhoz. A reakció vizes közegben hasonló hozammal és diasztereoszelektivitással rövidebb idő alatt végbemegy, mely az átmeneti állapotok hidrogénkötésekkel megvalósuló nagyobb stabilizációjával ${ }^{38,39}$ magyarázható. A reakció alifás és aliciklusos $\beta$-aminosavakkal mono- és biciklusos $\beta$-laktámokat eredményez. ${ }^{40-}$ 42

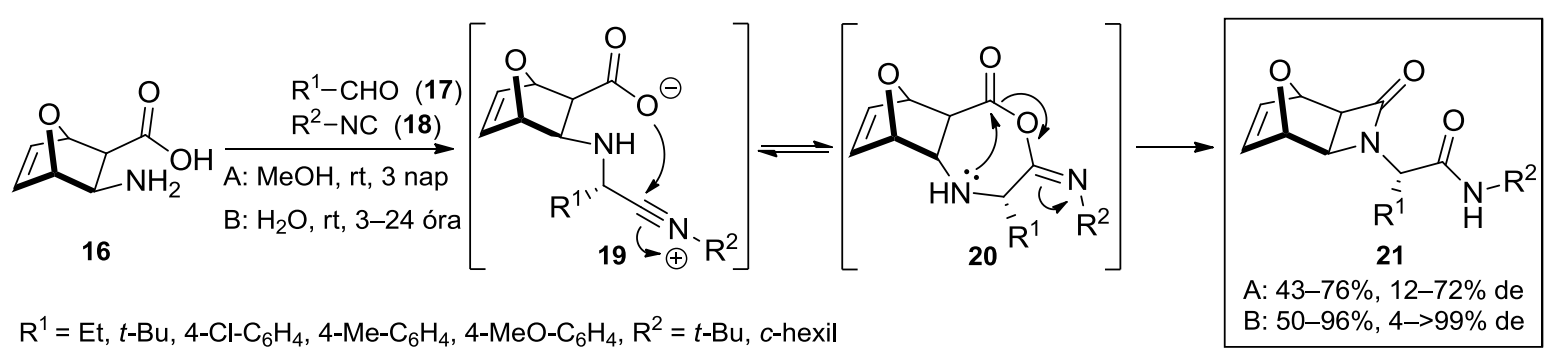

6. ábra. Diasztereoszelektív Ugi-4C-3CR $\beta$-laktám szintézis

Érdekesség, hogy $\alpha$-aminosavak esetében az intermolekuláris stabilizáció szintén végbemegy, azonban Mumm-átrendeződés és gyürüfeszült 2-oxoaziridin képződés helyett a 25 hattagú köztitermék az oldószerként jelen lévő metanollal reagálva a $26 \alpha, \alpha$ '-iminodikarbonsav származékokat adja. ${ }^{43}$ A magas hozammal és diasztereoszelektivitással lejátszódó reakció az ötcentrumú-négykomponensű Ugi-reakciók egyik példája (Ugi-5C-4CR) (7. ábra).

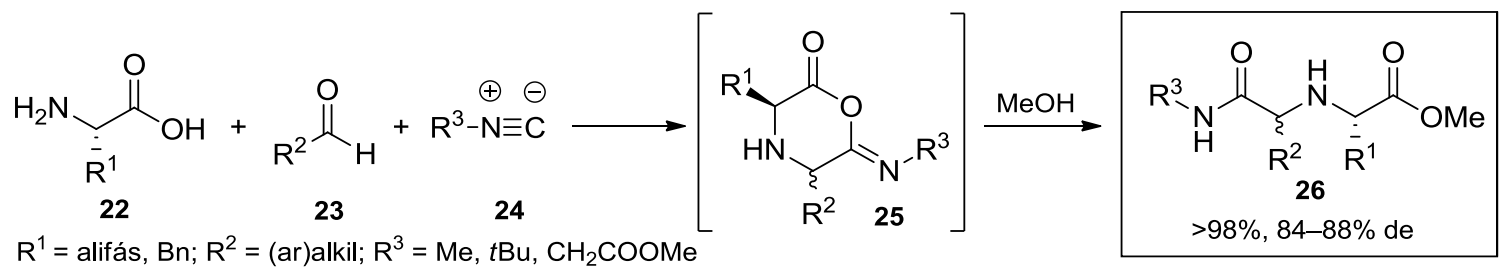

7. ábra. Diasztereoszelektív Ugi-5C-4CR $\alpha$-aminosavval

Kobayashi és kutatócsoportja a királis $\mathbf{2 7} \gamma$-keto-karbonsavakból kiindulva jó hozammal, de mérsékelt diasztereoszelektivitással a $31 \beta$-hidroxi- $\gamma$-laktámokat állította elő (8. ábra). ${ }^{44}$ Később a proteáz inhibítor omuralid totálszintézisének részlépéseként a reakció 
diasztereoszelektivitását a 27 levulinsav-származék hidroxil funkciós csoportjának védésével (nagyobb térkitöltés elérésével) jelentősen megnövelték (de >90\%). ${ }^{45,46}$

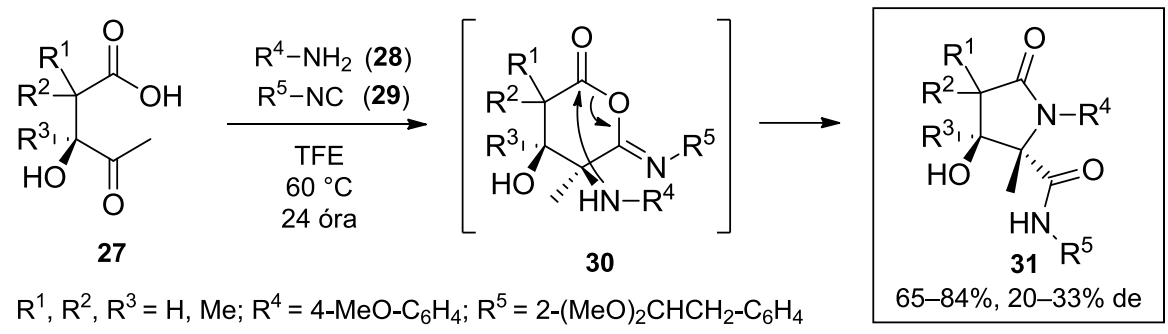

8. ábra. Diasztereoszelektív Ugi-4C-3CR $\gamma$-laktám szintézis

Megjegyzendő, hogy a nitrílium intermedier a karboxilát anion helyett inter- vagy intramolekuláris módon más $N$-, $S$-vagy $O$-nukleofilekkel is stabilizálódhat. Ezen alapulva az utóbbi évtizedekben számos módosított Ugi-reakció jelent meg, melyek változatos aromás és telített heterociklusok szintézisét lehetővé téve nagymértékben hozzájárultak az izocianid-alapú multikomponensű reakciókkal képezhető vegyületek struktúrális sokféleségének bővítéséhez. ${ }^{47}$

\subsection{Ugi-Joullié háromkomponensű reakció}

Az 1980-as évek elején Joullié pirrolin (32, n=1), 33 karbonsavak és 34 izocianidok felhasználásával a biológiailag releváns $35 \mathrm{~N}$-acilezett prolinszármazékok egy új típusú Uginégycentrumú háromkomponensű (U-4C-3CR) reakcióval megvalósított szintéziséről számolt be (9. ábra). ${ }^{48,49} \mathrm{Az}$ Ugi-Joullié néven ismertté vált reakció során a nitrílium köztitermék az eddig ismertetett példákhoz hasonlóan - a klasszikus Ugi-4CR mechanizmusát követve - karboxilátionnal stabilizálódik. A ciklusos imin reakciópartner tekintetében az irodalomban öttagú-, ${ }^{50-52}$ hattagú- ${ }^{50,53-55}$ és héttagú gyürük ${ }^{50,51,56}$ alkalmazása ismert, melyeket a legtöbb esetben gyürüs szekunder aminok in situ oxidációjával (gyakran $N$-klórozáson keresztül), laktámok redukciójával vagy aminoalkinek hidroaminálásával állítanak elő. ${ }^{57}$

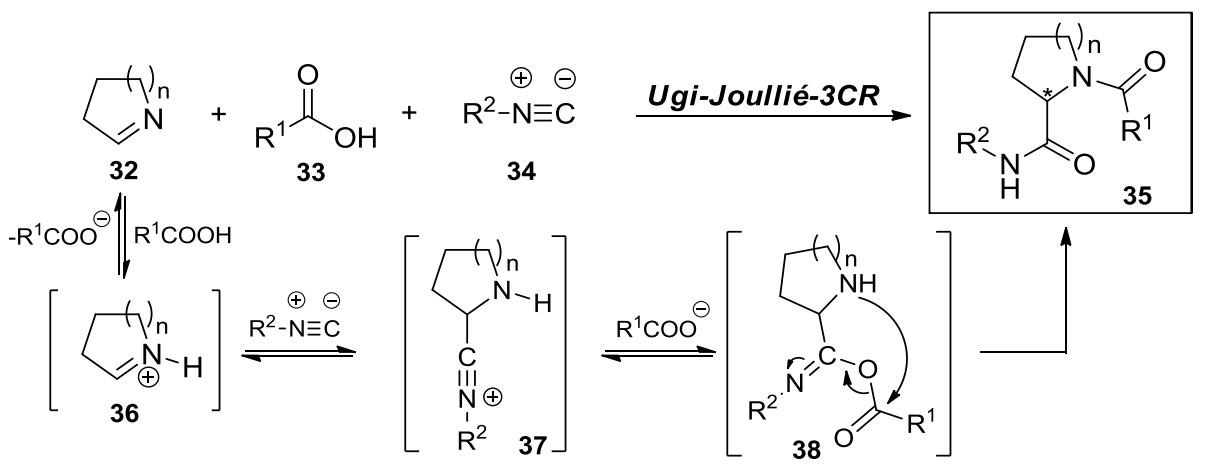

9. ábra. Ugi-Joullié-4C-3CR mechanizmusa 
A klasszikus Ugi-reakcióval szemben az Ugi-Joullié reakció apoláris oldószerekkel egyaránt kompatibilis, azonban a reakció diasztereoszelektivitását az oldószer polaritása nagymértékben befolyásolhatja. ${ }^{58}$ Orru és kutatócsoportja az optikailag aktív 41 és 42 pirrolinek, karbonsavak és izocianidok diklórmetánban történő kombinálásával egy magas hozamú és diasztereoszelektivitású Ugi-Joullié reakciót dolgozott ki (10. ábra). ${ }^{53}$ A 39 és 40 racém pirrolidin származékok biokatalitikus oxidatív deszimmetrizálásával nyert 41 és $\mathbf{4 2}$ ciklusos iminekre az izocianid addíciója a kevésbé térgátolt irányból valósult meg, transz 45 és 48 termékek képződéséhez vezetve. Megjegyzendő, hogy a nagyobb térigényü 42 pirrolin magasabb diasztereoszelektivitást eredményezett (>98\% de), míg a karbonsav és izocianid komponensek kémiai minősége a reakció sztereokémiai kimenetelét nem befolyásolta. A multikomponensü reakciók gyógyszerkémiai alkalmazhatóságát szemlélteti, hogy a szerzők a 41 pirrolinből kiindulva a hepatitisz C vírus NS3 proteáz inhibítor telaprevir 24 lépéses szintézisét Passerini3CR/Ugi-Joullié-3CR kulcslépések által 11 lépésre csökkentették. ${ }^{59}$

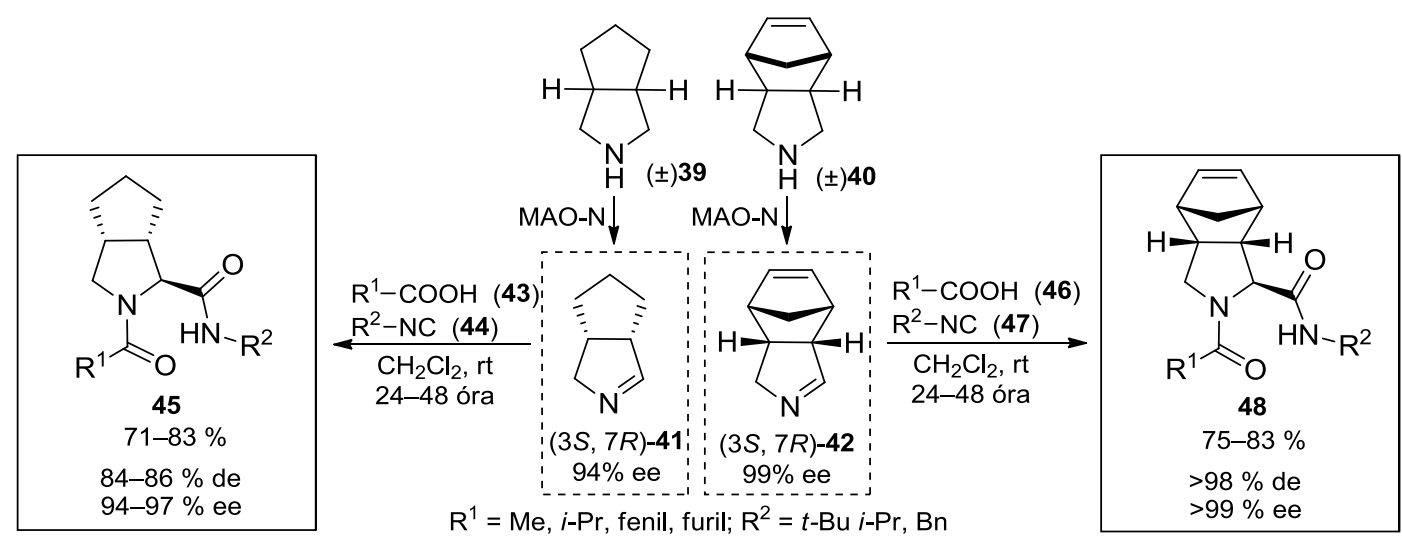

10. ábra. Diasztereoszelektív Ugi-Joullié-3CR királis pirrolinekkel

Overkleeft és kutatócsoportja az 53 L-ribóz származékból nyert 54 azidoaldehid tandem Staudinger/aza-Wittig reakciójával képzett 49 gyürüs imin, 50 karbonsavak és 51 izocianidok Ugi-Joullié reakciójával az $\mathbf{5 2}$ multiszubsztituált pirrolidin származékokat állította elő (11. ábra). ${ }^{60,61}$ Meglepő módon a reakció metanolban, additív hozzáadása nélkül ciszdiasztereospecifikus. Az izocianid térgátoltabb irányból történő addícióját a szerzők elektrosztatikus okokra vezették vissza; az imínium-ionra addícionálódó izocianidot a benziloxicsoportok TS-1 átmeneti állapot esetén stabilizálhatják. ${ }^{62} \mathrm{~A}$ reakció körülményeinek változtatása azonban szignifikáns hatással van a diasztereomer arányra. Lewis-savak (például $\mathrm{InCl}_{3}, \mathrm{ZnCl}_{2}$, $\mathrm{HgBr}_{2}$ ) hozzáadása, a hőmérséklet növelése, valamint a koncentráció csökkentése a cisz termék mellett a 52b 2,3-transz-pirrolidin képződését is eredményezi. Érdekesség, hogy a reakció apoláris oldószerekben Lewis-savak alkalmazása mellett is cisz-szelektív. 


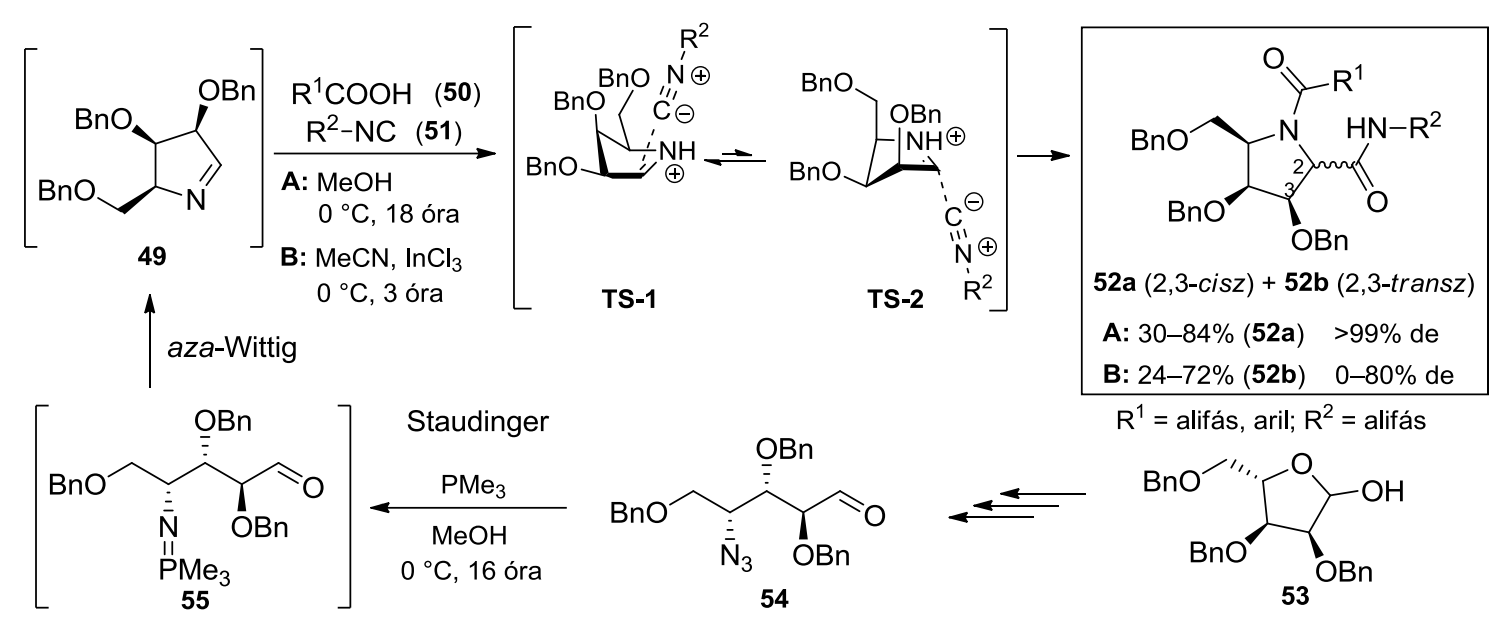

11. ábra. Diasztereodivergens Ugi-Joullié-3CR királis D-lixo-pirrolinnel

Az Ugi-Joullié reackió oldószerfüggésére egy további érdekes példa az 56 laktámból Schwartz reagenssel előállított $\mathbf{5 8}$ sziloxi-pirrolin diasztereodivergens reakciója, mely az előző példához hasonlóan apoláris oldószerekben (toluol, DKM) cisz 62 főterméket eredményez, míg a poláris hexafluor-izopropanol vagy trifluoretanol alkalmazásakor a transz 64 izomer keletkezik (12. ábra). ${ }^{58} \mathrm{~A}$ feltételezett reakciómechanizmus szerint apoláris oldószerekben az imin aktivációját követően a Coulomb kölcsönhatással stabilizált 61 kontakt ionpár jön létre, mellyel az izocianid addíciója $S_{\mathrm{N}} 2$ átmeneti állapoton keresztül a sziloxicsoport irányából valósulhat meg, cisz terméket eredményezve (12. ábra, A reakcióút). Ezzel szemben poláris közegben a szolvatáció eredményeként a $\mathbf{6 3}$ oldószer-szeparált ionpár keletkezik, mely a transz termék képződéséhez vezet (12. ábra, B reakcióút). Érdekesség, hogy a reakció diasztereoszelektivitását az izocianid kémiai minősége is befolyásolja; elektronszegény aromás izocianidokkal az alkalmazott oldószertől függetlenül a reakció cisz-szelektív.

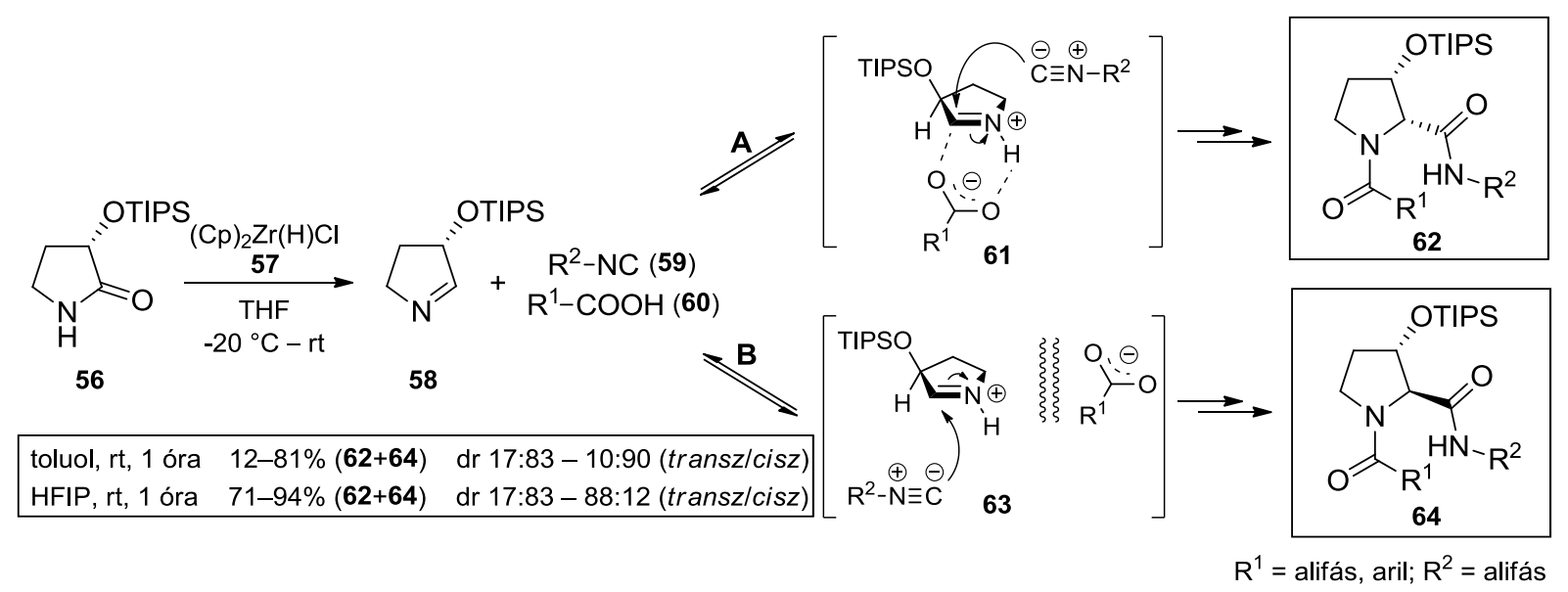

12. ábra. Diasztereodivergens Ugi-Joullié-3CR királis sziloxi-pirrolinnel 
Fontos kiemelni, hogy a szakirodalomban a farmakológiai szempontból ígéretes gyürüs aminosavszármazék $N$-acilaziridin-2-karboxamid vegyületcsalád elöállítását célzó, $2 H$-azirin alapú Ugi-Joullié reakció meglepő módon nem ismert.

\section{3. $N$-acilaziridin-2-karboxamidok}

A nem proteinogén $1 H$-aziridin-2-karbonsav (Azy) a legkisebb ciklusos aminosav. Ezen természetben ritkán előforduló ${ }^{14}$ merev alegység felhasználásával számos $N$-acilaziridin-2karboxilát és 2-karboxamid származékot állítottak elő, melyek többek között a malária, a Leishmania-fertőzés vagy az afrikai álomkór terápiáját célozva különféle humán és parazitális cisztein proteázok hatékony irreverzibilis inhibítorainak bizonyultak. ${ }^{63-74}$ (Az irreverzibilis kölcsönhatás mechanizmusa az aziridin gyürü és a fehérje aktív centrumában található cisztein oldallánc tiol funkciós csoportja között megvalósuló gyürünyitási reakción alapul. ${ }^{64}$ ) Kiemelendő, hogy Schirmeister és kutatócsoportja nagyszámú $N$-szubsztituálatlan- és $N$-acilezett aziridinil-peptidet szintetizált, melyek közül több vegyület is jelentős, esetenként nanomólos koncentrációjú papain, rodesain, klosztripain, falcipain és katepszin (cisztein proteázok) inhibítor aktivitást mutatott. ${ }^{68-74}$

Az $N$-acilaziridin-2-karboxamidok elöállítására rendkívül kevés, kizárólag többlépéses eljárások ismertek a szakirodalomban. ${ }^{75-86}$ A leggyakrabban alkalmazott szintetikus startégiák védett szerin vagy treonin aminosavakból indulnak ki, melyek során az aziridin gyürü kiépítése az aminosav hidroxil funkciós csoportjának kihasználásával, a gyürühöz kapcsolódó amid kötések kialakítása pedig hagyományos peptidkapcsolási technikákkal történik. ${ }^{78-83} \mathrm{Az}$ aminosav alapú megközelítésre egy kiváló példa a 71 Azy-csoportot tartalmazó tripeptidek ötlépéses előállítása (13. ábra). Gin és kutatócsoportja a reakciósor első lépésében a $65 \mathrm{~N}$-tritilszerin és a 66 alanin-benzilészter felhasználásával, BOP kapcsolószer segítségével a 67 dipeptidet képezte, melyböl metánszulfonát-észterré alakítást követően intramolekuláris $\mathrm{S}_{\mathrm{N}} 2$ reakcióval a $\mathbf{6 8} \mathrm{N}$-tritilaziridin intermediert nyerte. ${ }^{81,82}$ A tritil védőcsoport TFA-val történő eltávolítását követően az aziridin gyürü $N$-acilezését az első lépés során alkalmazott peptidkapcsolási módszerrel különböző Boc-védett aminosavakkal végezte. 


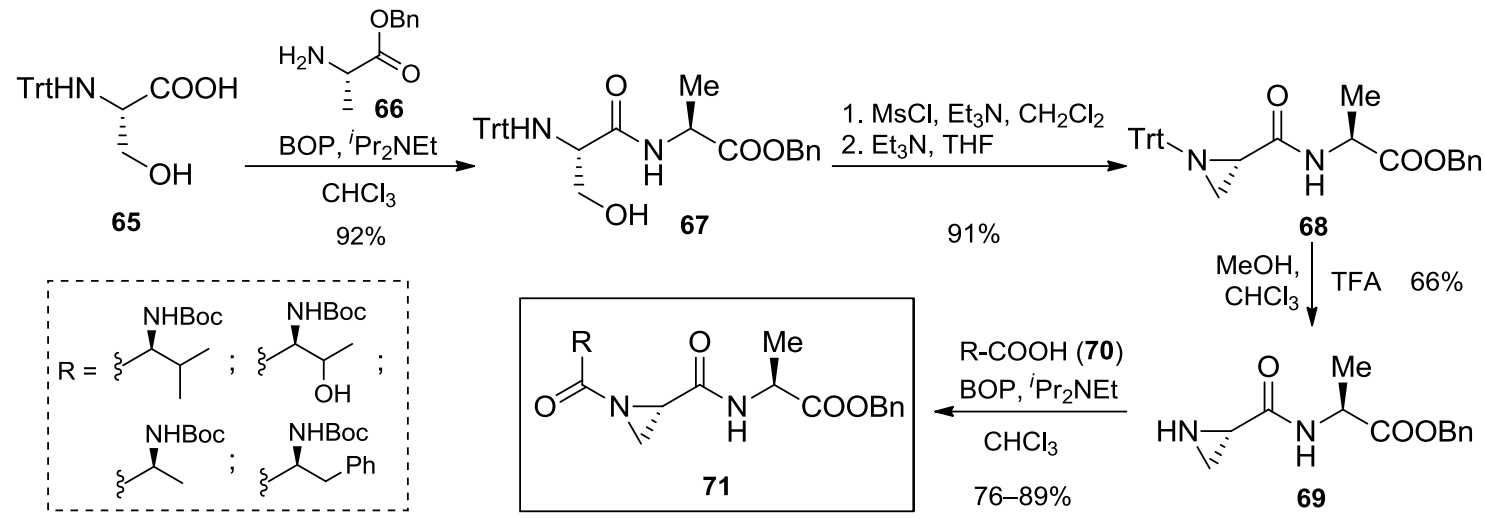

13. ábra. $N$-acilaziridin-2-karboxamidok aminosav alapú előállítása I.

Az előbb ismertetett szintetikus stratégia hátránya, hogy az aziridin egyik diverzitási pontja, a 2-karboxamid szubsztituens, az első lépésben kerül kialakításra. Spork és Donohoe a reakciólépések sorrendjén változtatva a $72 N$ - és $C$-védett szerinből kiindulva elsőként a gyürüzárást végezte el, melyet az észtercsoport reduktív debenzilezése követett (14. ábra). ${ }^{83} \mathrm{~A}$ karboxamid szubsztitensek kiépítése a $\mathbf{7 4}$ kulcsintermedierből három lépésben, klasszikus kapcsolási technikát (EDC/HOBt) alkalmazva történt.

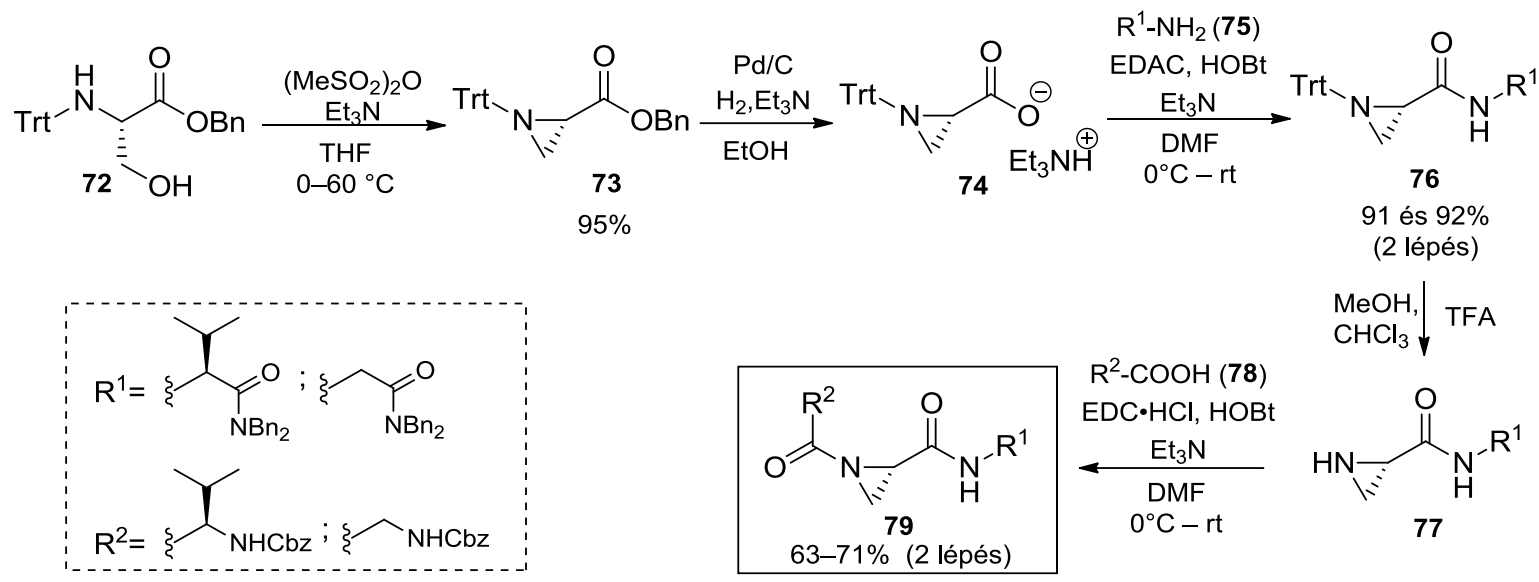

14. ábra. $N$-acilaziridin-2-karboxamidok aminosav alapú előállítása II.

Marsini és csoportja az aziridin gyürüt az enantiotiszta $80 \mathrm{~N}$-terc-butánszulfinil-ketiminészter és a $\mathbf{8 1}$ trimetilszulfoxónium jodidból nátrium-hidriddel in situ előállított dimetiloxoszulfónium-metilid aza-Corey-Chaykovsky reakciójával képezte (15. ábra). ${ }^{84} \mathrm{~A}$ magas diasztereoszelektivitással előállított $\mathbf{8 2}$ etil-aziridin-2-karboxilát származékok alkalmazhatóságát demonstrálva az egyik vegyületet ezt követően klasszikus peptidkapcsolással, majd a szulfinilcsoport savas hidrolízisével, végül egy újabb amidkötés kialakításával a $86 \mathrm{~N}$-acilaziridin-2-karboxamiddá alakította. A módszer előnye, hogy az $\mathrm{R}^{1}$ szubsztituens révén nagyobb diverzitású aziridinek előállítása valósítható meg. 


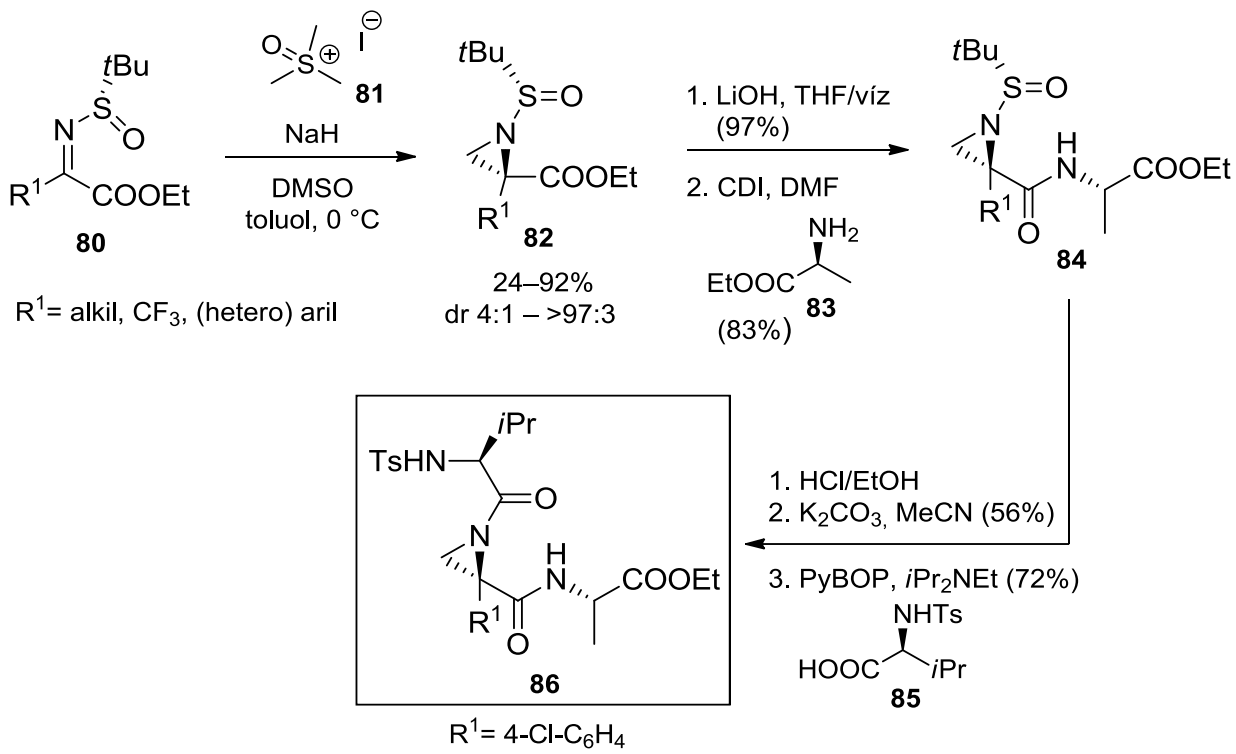

15. ábra. $N$-acilaziridin-2-karboxamidok elöállítása $N$-szulfinil-ketiminészterekből

Tardella és kutatócsoportja egy olyan alternatív szintézismódszert dolgozott ki, mellyel változatosabb szubsztitúciós mintázatú $N$-acilaziridin-2-karboxamidok nyerhetők. ${ }^{85,86}$ A 87 ciánecetsav és $88 \alpha$-aminoészter kapcsolásával képzett 89 aktív metiléncsoportot tartalmazó ciánacetamidokból különböző aldehidekkel elsőként a 91 Knoevenagel termékeket állította elő, melyeken az elektrofil aminálószer 92 noziloxikarbamáttal kálcium-oxid jelenlétében, mérsékelt-jó diasztereoszelektivitással aziridin gyürüt alakított ki (16. ábra). A céltermék $95 \mathrm{~N}$ acilaziridin-2-karboxamid származékokhoz a Boc védőcsoport eltávolítása után DCC kapcsolószerrel, egy újabb $\alpha$-aminosav egység felhasználásával jutott el.
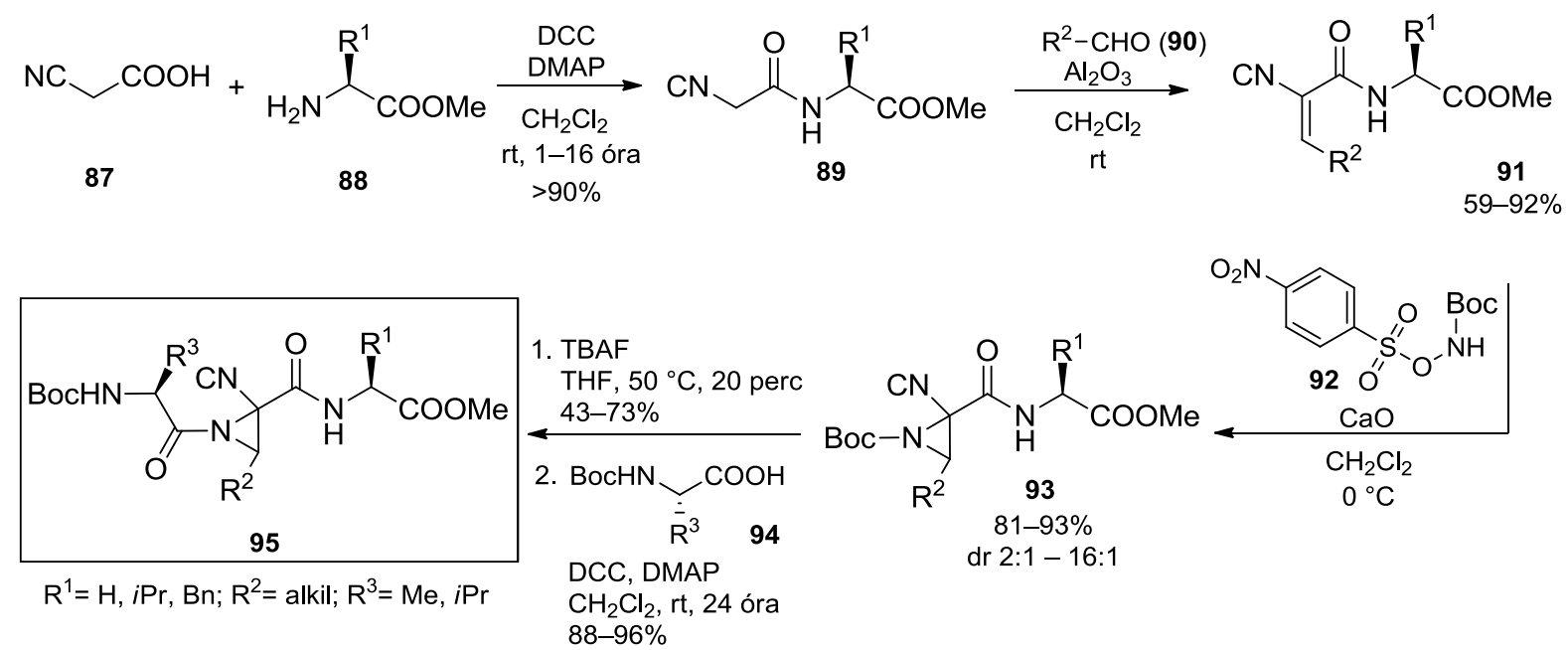

16. ábra. $N$-acilaziridin-2-karboxamidok előállítása ciánacetamidokból 
A molekulában lévő nagy gyürüfeszültségből (a ciklopropánéhoz hasonlóan 26-27 $\mathrm{kcal} / \mathrm{mol}$ ) eredően az aziridinek változatos nitrogéntartalmú vegyületek prekurzoraiként alkalmazhatók, mely különböző nukleofilekkel végbemenő gyürünyitási reakciókkal szemben mutatott fokozott reakcióképességnek köszönhető. ${ }^{1}$ A gyürüfelnyílási készséget azonban az aziridin elektronikus sajátsága jelentősen befolyásolja. Míg az $N$-szubsztituálatlan, illetve $N$ alkil-aziridinek reaktivitása viszonylag alacsony (,aktiválatlan aziridinek”), a nitrogénatomon elektronszívó szubsztituensek, úgymint acil-, szulfonil-, szulfinil-, foszforil- vagy foszfinilcsoportok jelenléte nagymértékben növelik a vázrendszer reaktivitását (,aktivált aziridinek"). ${ }^{87} \mathrm{Az}$ aktiválás főként induktív effektusra vezethető vissza, mivel a gyürüfeszültség további növekedése miatt az amidát-szerű mezomer határszerkezet (17. ábra) kialakulása nem kedvezményezett. ${ }^{13}$ Megjegyzendő, hogy a gyürünyitás a legtöbb esetben Lewis- vagy Brønstedsav katalízissel is elősegíthető. ${ }^{8,13,87}$ Nem szimmetrikusan szubsztituált aktivált aziridineknél két regioizomer képződhet, azonban a nukleofil támadás - az arilaziridinek kivételével - legtöbbször a sztérikusan kedvezőbb szénatomon valósul meg, ${ }^{13}$ melyre egy szemléletes példa a $99 \mathrm{~N}$ acilaziridin-2-karboxamid származék ecetsavanhidriddel végrehajtott gyürünyitása (17. ábra). ${ }^{88}$ Az $\mathrm{S}_{\mathrm{N}} 2$ mechanizmust követő, inverzióval járó reakció érdekessége, hogy annak ellenére, hogy a nukleofil támadás elektronikus szempontból a C-2 szénatomon várható, a gyürünyitás sztérikus okok miatt kizárólag a $\mathbf{1 0 0}$ L-allo-treonin analógot eredményezi.

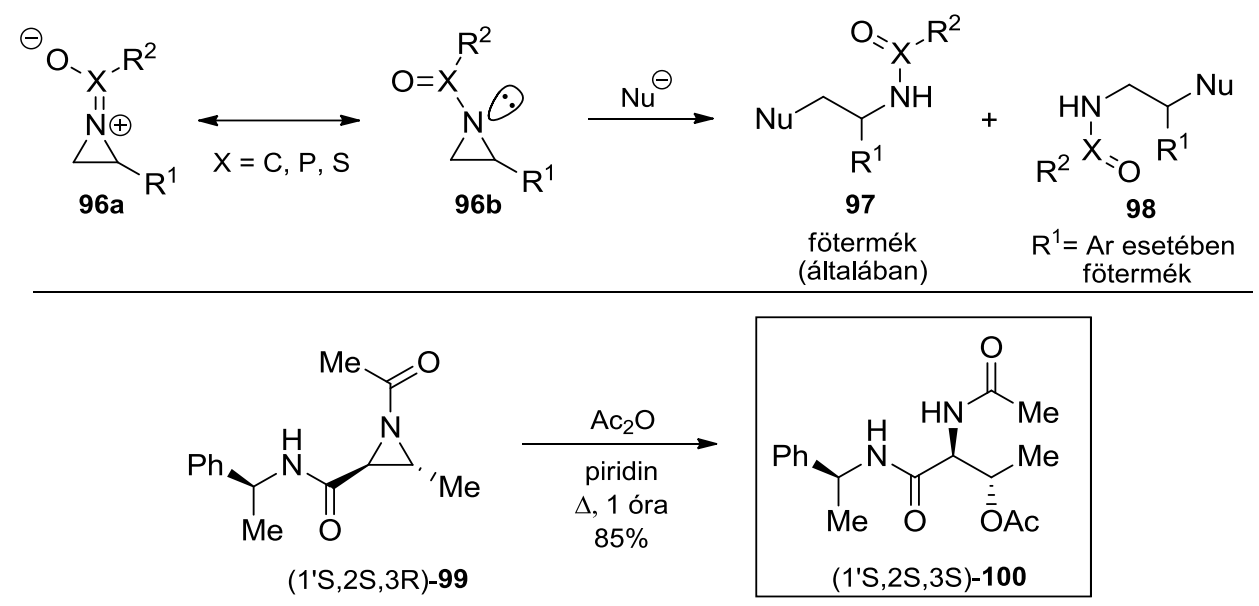

17. ábra. Aktivált aziridinek gyürünyitása

A gyürűnyitás regioszelektivitását az aziridin gyürü szubsztitúciós mintázatán és a támadó nukleofil reakciópartner kémiai minőségén túl az alkalmazott reakciókörülmények is befolyásolhatják. ${ }^{11}$ Papa és Tomasini a $( \pm)$-101 multiszubsztituált $N$-acil-aziridin vízzel történő gyürüfelnyílását vizsgálva, a reakciót $\mathrm{BF}_{3} \cdot 2 \mathrm{H}_{2} \mathrm{O}$ Lewis-sav jelenlétében, több oldószerben végrehajtva például azt tapasztalta, hogy míg diklórmetánban kiváló hozammal a $( \pm)-\mathbf{1 0 2} \alpha-$ 
hidroxi- $\beta$-aminosav származék keletkezik, dimetil-formamidban a regioizomer $( \pm)$-103 $\beta$ hidroxi- $\alpha$-aminosav analóg képződik (18. ábra). ${ }^{89}$

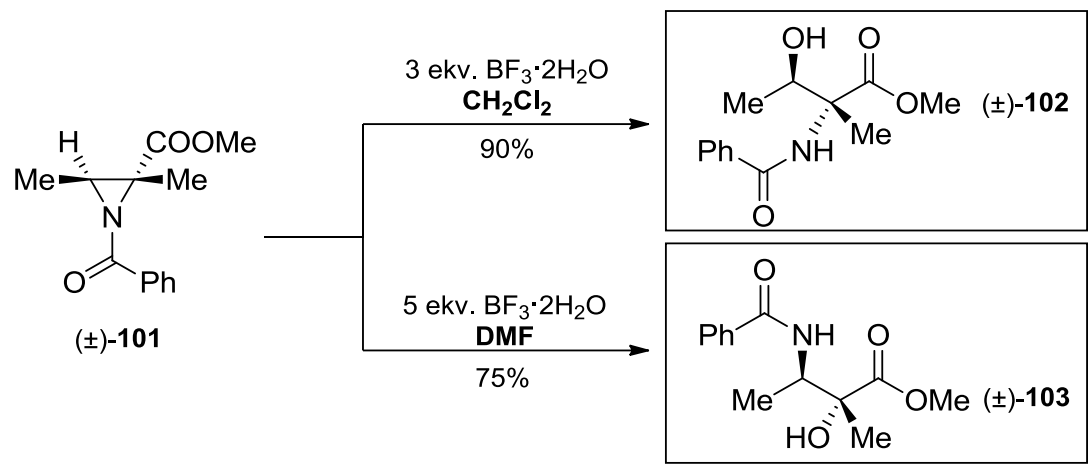

18. ábra. A reakciókörülmények hatása az $N$-acilaziridinek gyürünyitásának regioszelektivitására

Lygo a $104 \beta$-ketoészterből képzett dianionnal különböző $105 N$-acilaziridineket reagáltatva gyürüfelnyílás helyett a $\mathbf{1 0 6}$ diketoészter származékok képződését tapasztalta (19. ábra).${ }^{90}$ Ez a $\beta$-ketoészterek $C$-acilezésére alkalmas újfajta regioszelektív reakció egy szemléletes példa arra, hogy hard nukleofilek alkalmazásakor az $N$-acilaziridinek acildonorként szolgálhatnak.

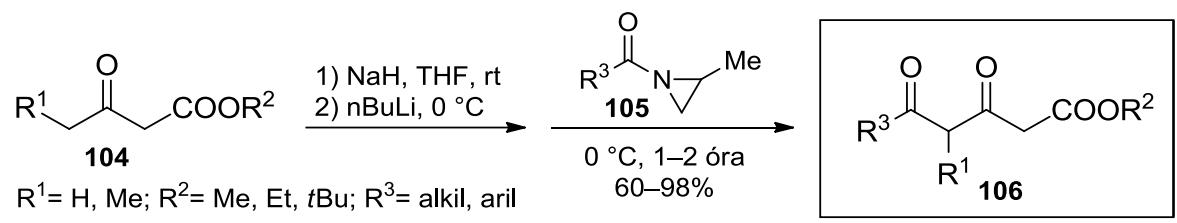

19. ábra. $N$-acilaziridinek, mint acildonorok

A változatos gyürünyitási reakciók mellett az $N$-acilaziridinek jellegzetes átalakítási lehetősége az oxazolinná történő izomerizáció, amely termikus és savas (Lewis- és Brønstedsavak) körülmények között, illetve nukleofilek (pl.: NaI, NaSCN) részvételével (Heine reakció) is lejátszódhat. ${ }^{11} \mathrm{Az}$ oxazolinná alakítás sztereospecifikus, az alkalmazott körülményektől függetlenül a konfiguráció retenciójával jár, mely a reakció mechanizmusával magyarázható. ${ }^{91-}$ ${ }^{93} \mathrm{Az}$ acetonban, acetonitrilben és a 2-propanolban hatékony ${ }^{94}$ Heine reakcióban ${ }^{95,96}$ két egymást követő, inverzióval járó $\mathrm{S}_{\mathrm{N}} 2$ reakciólépés, a jodid vagy tiocianát anionnal megvalósuló gyürünyitás, majd intramolekuláris gyürüzárás eredménye a retenció (20. ábra, A). Lewis-savak $\left(\mathrm{BF}_{3} \cdot \mathrm{Et}_{2} \mathrm{O}^{97,98}\right.$ vagy azafil $\mathrm{MgBr}_{2}, \quad \mathrm{Zn}(\mathrm{OTf})_{2}, \quad \mathrm{Sn}(\mathrm{OTf})_{2}$ és $\mathrm{Cu}(\mathrm{OTf})_{2}$ fémsók $\left.{ }^{93,99,100}\right)$ alkalmazásakor a $\mathbf{1 1 1}$ átmeneti állapoton keresztüli $S_{N i}$ mechanizmus szolgáltatja a 107 aziridinnel megegyező konfigurációjú 110 oxazolint (20. ábra, B). 


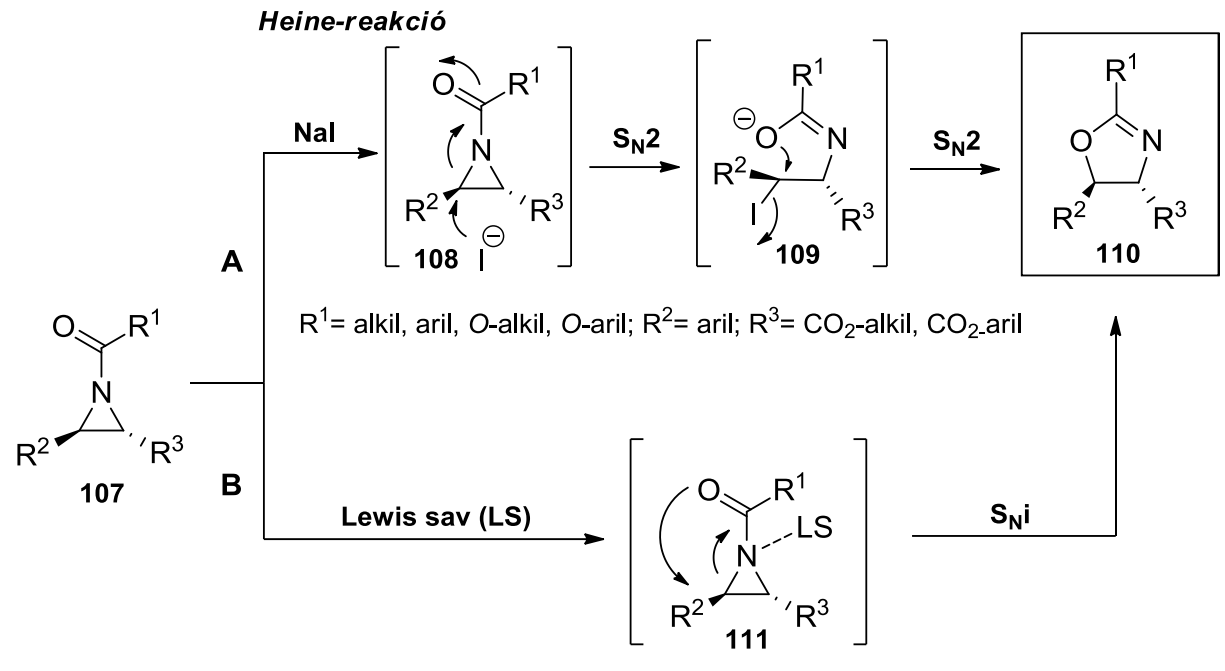

$\mathrm{R}^{1}=$ alkil, aril; $\mathrm{R}^{2}=$ alkil, aril; $\mathrm{R}^{3}=\mathrm{H}$, alkil, $\mathrm{CO}_{2}$-alkil

20. ábra. Az $N$-acilaziridinek oxazolinná történő izomerizációja

A gyürübővítés regioszelektivitását a kiindulási aziridin szubsztitúciós mintázata és az alkalmazott reakciókörülmények egyaránt befolyásolják, melyet a 112 és $115 \mathrm{~N}$-acilaziridin-2karboxamidok oxazolinná alakítása kiválóan szemléltet. Cardillo és kutatócsoportja $112 \mathrm{~N}$ acilaziridinből kiindulva különböző oldószerek és Lewis-savak felhasználásával a 113 és 114 regioizomerek változó arányú keverékét kapták, azonban míg tetrahidrofurán oldószerben egy ekvivalens $\mathrm{BF}_{3} \cdot \mathrm{Et}_{2} \mathrm{O}$ alkalmazása a 114 oxazolin képződésének kedvezett, $\mathrm{MgBr}_{2} \cdot \mathrm{Et}_{2} \mathrm{O}$ Lewissav mellett szinte kizárólag a $\mathbf{1 1 3}$ izomer keletkezett (21. ábra, A). ${ }^{101}$ Emellett jelentős oldószerhatást is tapasztaltak, mivel a tetrahidrofurán toluolra cserélése mindkét sav esetében a szelektivitás csökkenését eredményezte. Érdekesség, hogy az izopropil-csoporttal szubsztituált 115 analóg átalakítása $\mathrm{BF}_{3} \cdot \mathrm{Et}_{2} \mathrm{O}$ felhasználásával kizárólag a nem várt izomert, a 117 szin $\mathrm{N}$ acetil-hidroxileucin prekurzoraként szolgáló 116 oxazolint eredményezte (21. ábra, B). ${ }^{102}$
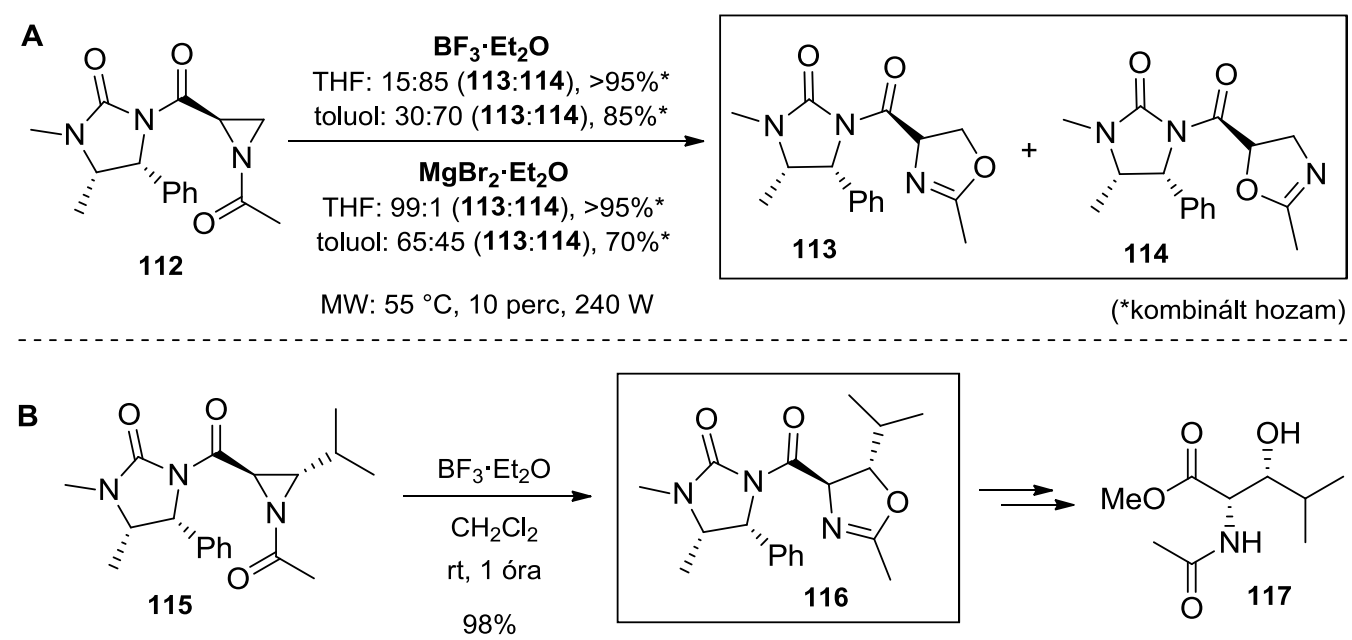

21. ábra. $N$-acilaziridin-2-karboxamidok oxazolinná történő izomerizációjának regioszelektivitása 


\section{4. $2 H$-azirinek cikloaddíciós reakciói}

A feszült gyürürendszernek és az elektronban gazdag $\mathrm{C}=\mathrm{N}$ kettős kötésnek köszönhetően a $2 H$ azirinek változatos cikloaddíciós reakciók $2 \pi$ elektron donorai. ${ }^{1,2,4,5,103,104}$ Dienofil komponensként többek között (benzo)furánnal, ${ }^{105-108}$ nyílt láncú és ciklikus diénekkel, ${ }^{107-113}$

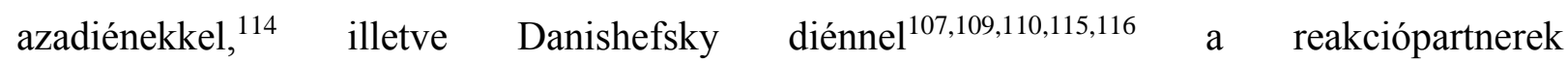
szubsztituáltságának függvényében normál és inverz elektronigényü Diels-Alder reakciókban egyaránt részt vesznek, a ( \pm -123-126 azabiciklo[4.1.0]heptán-vázas vegyületeket eredményezve (22. ábra). A [4+2]-cikloaddíciók a (benzo)furánnal végbemenő reakciók kivételével endo szelektívek, a dienofil az azirint a kevésbé térgátolt ${ }^{5}$ oldaláról közelíti meg. A Diels-Alder reakciók elektronvonzó csoportokkal 2-, illetve 3-szubsztituált azirinek esetén a leghatékonyabbak, azonban Lewis-savakkal (például $\mathrm{MgCl}_{2}, \mathrm{ZnCl}_{2}, \mathrm{YbCl}_{3}$ felhasználásával) az alkil és aril-szubsztituált azirinek reakciói elősegíthetők. ${ }^{109-111,116}$

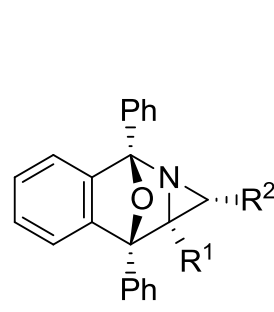

$( \pm)-123$<smiles>[R]C1NC(=O)C([R2])[C@@]2([R])C([R])N12</smiles>

(士)-125

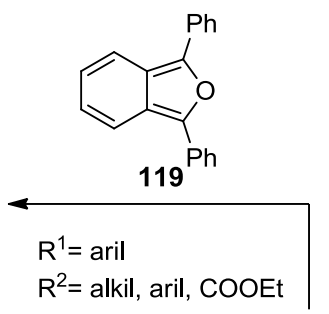

${ }^{1}{ }^{1}{ }_{R^{2}}$

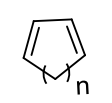

120

(Lewis-sav)

$\mathrm{R}^{1}=$ aril, aralkil, COOR,

COAr; $R^{2}=H$, alkil, aril;

$n=0-2$

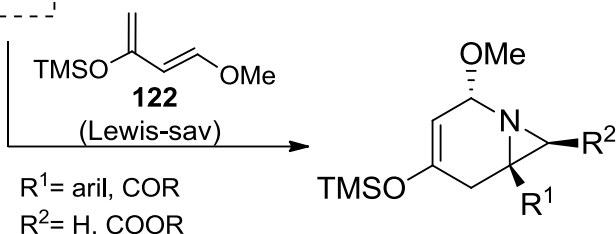

(土)-126

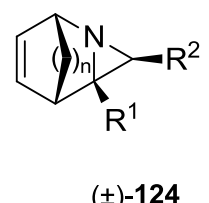

(士)-124

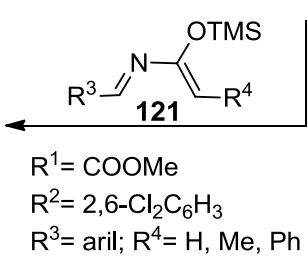

$\mathrm{R}^{3}=$ aril; $\mathrm{R}^{4}=\mathrm{H}, \mathrm{Me}, \mathrm{Ph}$

22. ábra. $2 H$-azirinek Diels-Alder reakciói

A Diels-Alder reakcióval szemben az azirinek, mint dipolarofilek 1,3-dipoláris cikloaddíciós reakciói kevésbé tanulmányozottak, csupán a következő néhány diazometán, nitriloxid és azometin-ilid dipólokkal végrehajtott átalakításuk ismert.

2H-azirinek és diazometán 1,3-dipoláris cikloaddíciójáról elsőként Logothetis számolt be. ${ }^{117}$ A 127 diszubsztituált azirin és diazometán reakciója azonban a várt 128 triazolin cikloaddukt spontán átrendeződésével a 129 allil-azid képződéséhez vezetett (23. ábra). Érdekesség, hogy a C-2-es helyzetben szubsztituálatlan azirinből keletkező 130 allil-azid egy 
újabb in situ cikloaddíciós lépésben vesz részt, a 131 4,5-dihidro-3H-pirazol származékot szolgáltatva (23. ábra). ${ }^{118}$

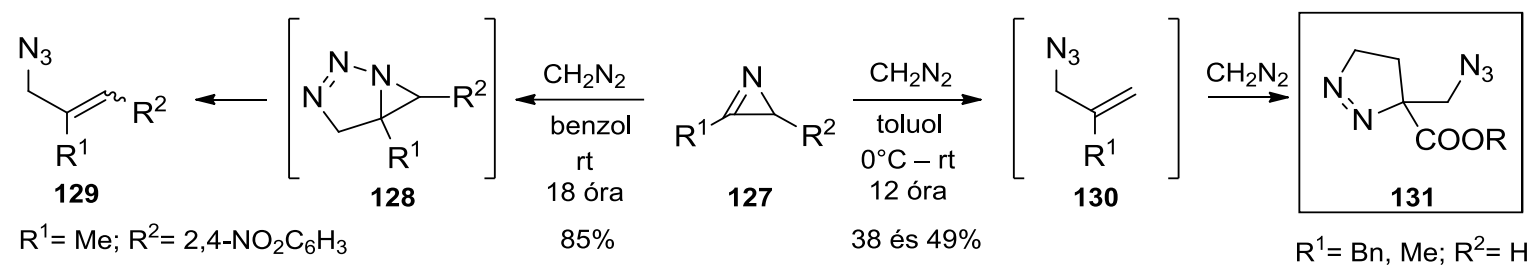

23. ábra. 2H-azirinek és diazometán 1,3-dipoláris cikloaddíciója

A nitril-oxidok $4 \pi$-elektronrendszere is részt vehet 1,3-dipoláris cikloaddícióban $2 H$ azirinnel, azonban a keletkező 134 cikloaddukt ebben az esetben is instabil, a reakciókörülmények függvényében kétféle módon rendeződik át. Míg $0{ }^{\circ} \mathrm{C}$-on egy izomerizációs lépést követő gyürüfelnyílást, majd az $\mathrm{R}^{3}$-csoport 1,2-migrációját követően a 138 karbodiimid képződéséről számoltak be, ${ }^{119}$ addig magasabb hőmérsékleten a 135 4H-1,2,4-oxadiazin képződése ismert (24. ábra). ${ }^{120}$

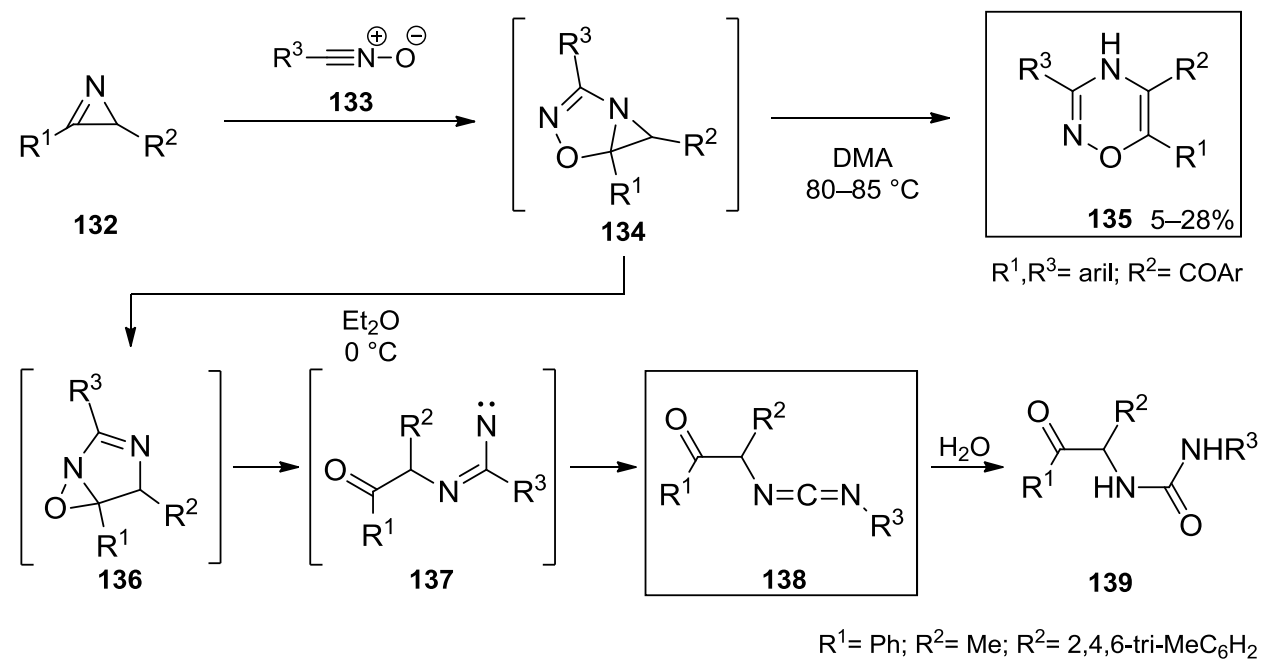

24. ábra. 2H-azirinek és nitril-oxidok 1,3-dipoláris cikloaddíciója

A változatos szintetikus alkalmazhatóságuknak köszönhetően az azometin-ilidek az egyik legintenzívebben kutatott 1,3-dipólok. ${ }^{121-125}$ Habár ismertek közöttük stabil származékok, általában in situ módon állíthatók elö ${ }^{121}$ (1) aziridinek termikus gyürűnyitásával, ${ }^{126,127}$ (2) $\alpha$ aminosavakból képzett iminek dekarboxileződésén keresztül, ${ }^{128-130}$ (3) iminium sók deprotonálásával, ${ }^{131,132} \quad$ (4) oxazolin intermedieren keresztül $^{133}$ vagy (5) szililamin származékok deszililezésével. ${ }^{134,135}$ A $2 H$-azirinekkel végbemenő 1,3-dipoláris cikloaddíciójuk egyik példája a 140 aziridinből termikus úton képzett 141 dibenzoxazepínium $\mathrm{W}$-ilid és a 142 aril-szubsztituált azirin oldószer nélküli reakciója, mely a ( \pm )-143 és $( \pm)$-144 
regioizomer cikloadduktok közel 1:1 arányú, jó hozamú, endo-szelektív képződését eredményezi (25. ábra). ${ }^{136}$

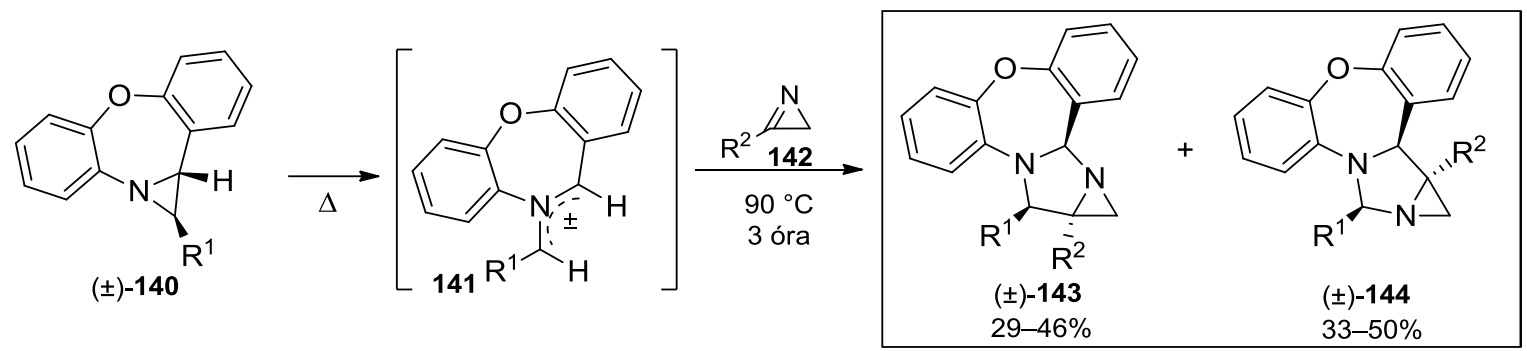

$\mathrm{R}^{1}=\mathrm{Ph}, 2-\mathrm{BrC}_{6} \mathrm{H}_{4} ; \mathrm{R}^{2}=\mathrm{Ph}, 2-\mathrm{BrC}_{6} \mathrm{H}_{4}, 4-\mathrm{NO}_{2} \mathrm{C}_{6} \mathrm{H}_{4}, 4-\mathrm{MeC}_{6} \mathrm{H}_{4}, 4-\mathrm{MeOC}_{6} \mathrm{H}_{4}$

25. ábra. 2H-azirinek és azometin-ilidek 1,3-dipoláris cikloaddíciója I.

A hasonló módon aziridinből képzett 146 azometin-ilid és a 147 2-brómazirin reakciója ezzel szemben instabil 148 cikloaddukthoz vezet, melyből konszekutív gyürübővítési, $\mathrm{HBr}$ eliminációs és aromatizációs reakciólépéseken keresztül alacsony hozammal a $\mathbf{1 4 9}$ pirimidin származék képződik (26. ábra). ${ }^{118}$

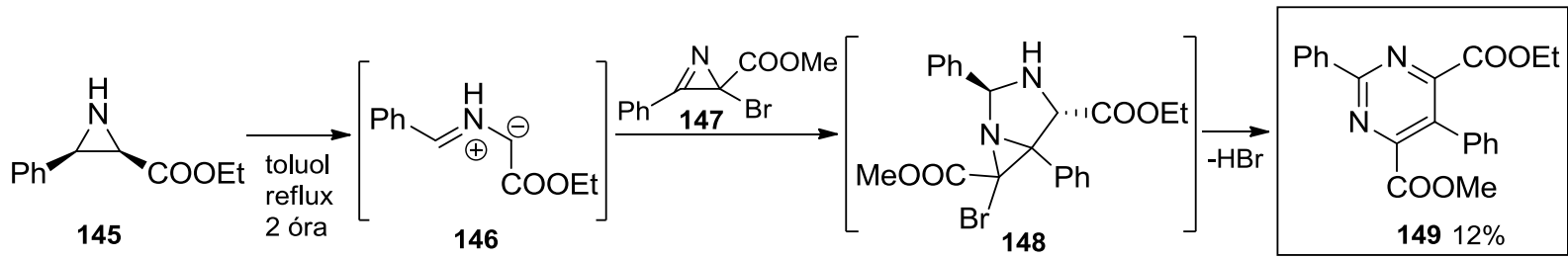

26. ábra. 2H-azirinek és azometin-ilidek 1,3-dipoláris cikloaddíciója II.

Gallagher és kutatócsoportja a 150 -laktám-vázas oxazolidinonból termikus úton képzett 151 azometin-ilid és a 152 mono-, illetve diszubsztituált $2 H$-azirinek 1,3-dipoláris cikloaddícióját vizsgálta (27. ábra). ${ }^{137}$ A reakciók - in situ dekarboxileződést követően - a $( \pm)$ 153a endo és $( \pm)$-153b exo triciklusos $\beta$-laktám származékok keverékének alacsony-közepes hozamú, regioszelektív képződését eredményezték.

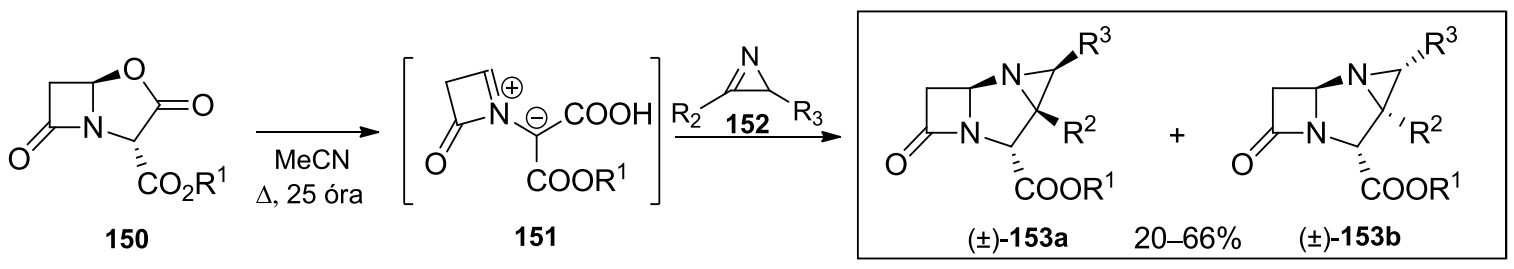

$\mathrm{R}^{1}=\mathrm{Me}, 4-\mathrm{NO}_{2} \mathrm{C}_{6} \mathrm{H}_{4} \mathrm{CH}_{2} ; \mathrm{R}^{2}=$ coome, coot-Bu, 4- $-\mathrm{NO}_{2} \mathrm{C}_{6} \mathrm{H}_{4} ; \mathrm{R}^{3}=\mathrm{H}, 2,6-$ di- $-\mathrm{ClC}_{6} \mathrm{H}_{3}, 4-\mathrm{NO}_{2} \mathrm{C}_{6} \mathrm{H}_{4}$

27. ábra. 2H-azirinek és azometin-ilidek 1,3-dipoláris cikloaddíciója III. 
Maurya és kutatócsoportja egy újszerü, látható fény vezérelt fotokaszkád katalízist dolgozott ki, mellyel az 1,3-dipoláris cikloaddíció azometin-ilid és azirin reaktánsai a 154 1,2,3,4-tetrahidro- $\beta$-karbolinból és $155 \alpha$-keto-vinilazidból $\mathrm{Ru}(\mathrm{bpy})_{3}\left(\mathrm{PF}_{6}\right)_{2}$ katalizátor jelenlétében fehér fénnyel in situ generálhatók (28. ábra, A). ${ }^{138}$ A katalizátor szerepe kettős, a 154 tercier amin azometin-iliddé oxidálásában és a 155 vinil-azid fotoszenzibilizált, 157 azirinné alakulásában egyaránt részt vesz. A cikloaddíciós lépés a várt $( \pm)$-158 $\beta$-karbolin származékokat kiváló (a legtöbb esetben teljes) regio- és diasztereoszelektivitással szolgáltatta. A szerzők a reakciót később $N, N$-dimetilanilinekre, mint azometin-ilid prekurzorokra kiterjesztve a $( \pm)-\mathbf{1 6 3}$ $N$-aril-1,3-diazabiciklo[3.1.0]hexán származékok diasztereoszelektív szintézisét is megvalósították (28. ábra, B). ${ }^{139}$
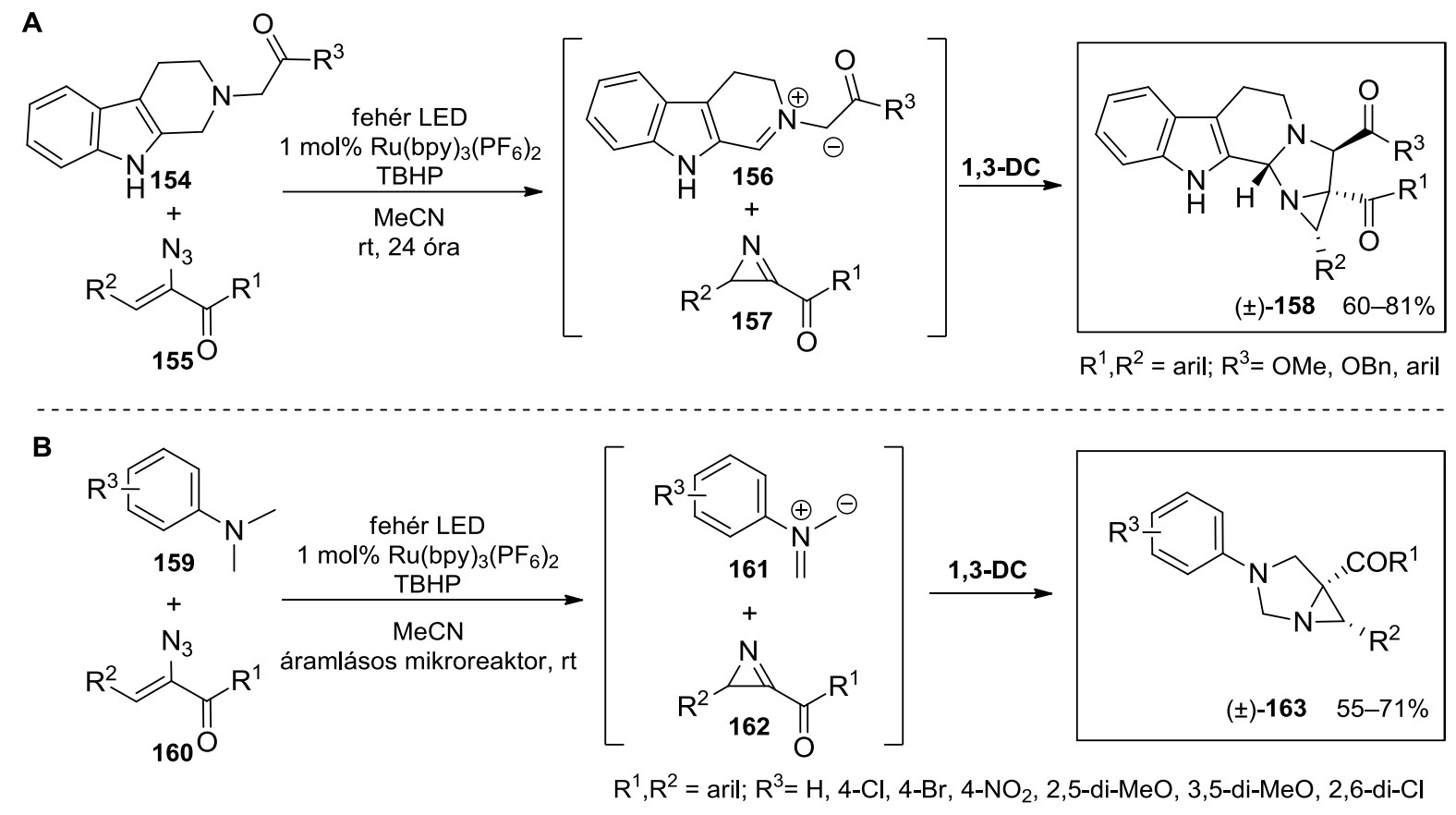

28. ábra. $2 H$-azirinek és azometin-ilidek 1,3-dipoláris cikloaddíciója IV.

Fontos kiemelni, hogy a $2 \mathrm{H}$-azirinek oxindol-alapú azometin-ilidekkel vagy nitronokkal végrehajtott 1,3-dipoláris cikloaddíciós reakcióit a szakirodalom nem ismerteti, így ezen reakciók megvalósíthatóságának tanulmányozása indokoltnak tűnt. Mivel az átalakítások egy új aziridinnel kondenzált spirooxindol vázrendszerhez, illetve tetraszubsztituált imidazolok keletkezéséhez vezettek, így a spirooxindolok jelentősége mellett a már ismert azirin alapú imidazolszintézisek áttekintése is nélkülözhetetlen. 


\subsection{Spirooxindolok}

A spirooxindol molekularész (164) amellett, hogy számos természetes alkaloid, mint például a Spirotryprostatin A (165), ${ }^{140}$ a (-)-Horsfiline (166) ${ }^{141}$ és a Mitrinermin (167) ${ }^{142}$ alapváza, kiemelt figyelemmel bír a gyógyszerkutatás területén (29. ábra). ${ }^{143-146}$ A nagyszámú, változatos farmakológiai aktivitást mutató szintetikus spirooxindolok közé tartozik többek között a maláriaellenes Cipargamin (168), ${ }^{147}$ a HDM2 antagonista MI-219 (171), ${ }^{148}$ a p53/MDM2 antagonista MI-888 (170) ${ }^{149}$ vagy a vazopresszin-2 receptor antagonista Satavaptan (169). ${ }^{150}$

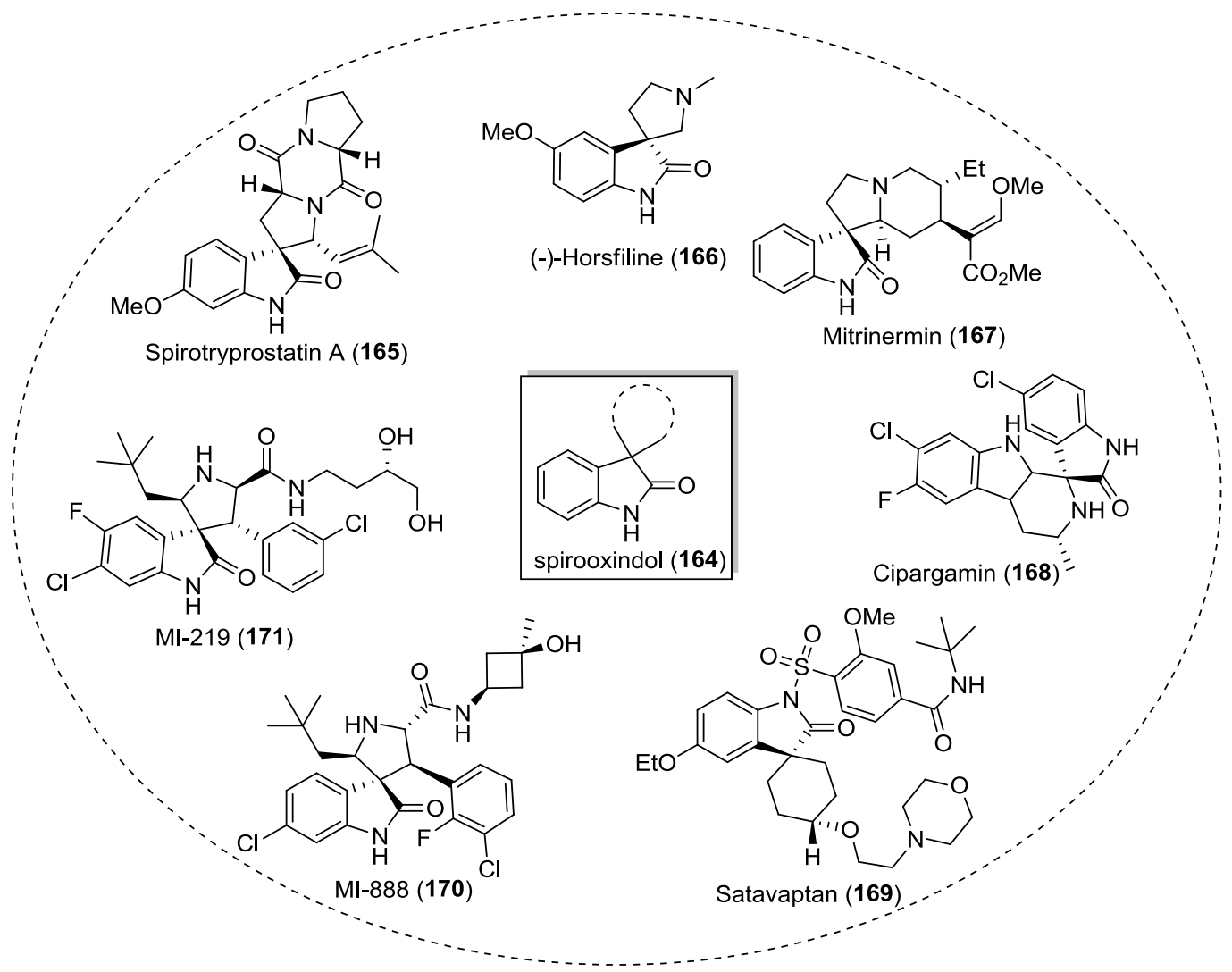

29. ábra. Néhány természetes és szintetikus spirooxindol származék

A spirooxindolok egyik leginkább tanulmányozott képviselői a spirooxindol-pirrolidinek. Ezen ígéretes biológiai potenciállal bíró vegyületcsalád szintézise leggyakrabban a $\mathbf{1 7 2}$ izatinok, $173 \alpha$-aminosavak és 175 aktivált alkének között végbemenő, dekarboxilatív kondenzációval in situ képződő 174 azometin-ilidek 1,3-dipoláris cikloaddícióján alapuló multikomponensü reakcióval történik (30. ábra). ${ }^{151-155}$ A módszer az izatinból származtatott 177 alkén dipolarofilekkel a $\mathbf{1 7 8}$ dispirooxindolok előállítására is kiterjeszthető. ${ }^{156-158}$ Az ilidképzés alternatív úton, a 179 diazoamid és 180 iminek Lewis-sav katalizált reakciójával, ${ }^{159,160}$ vagy aktív metiléncsoporttal rendelkező 181 iminből kiindulva báziskatalízissel is megvalósítható. ${ }^{161-164}$ 


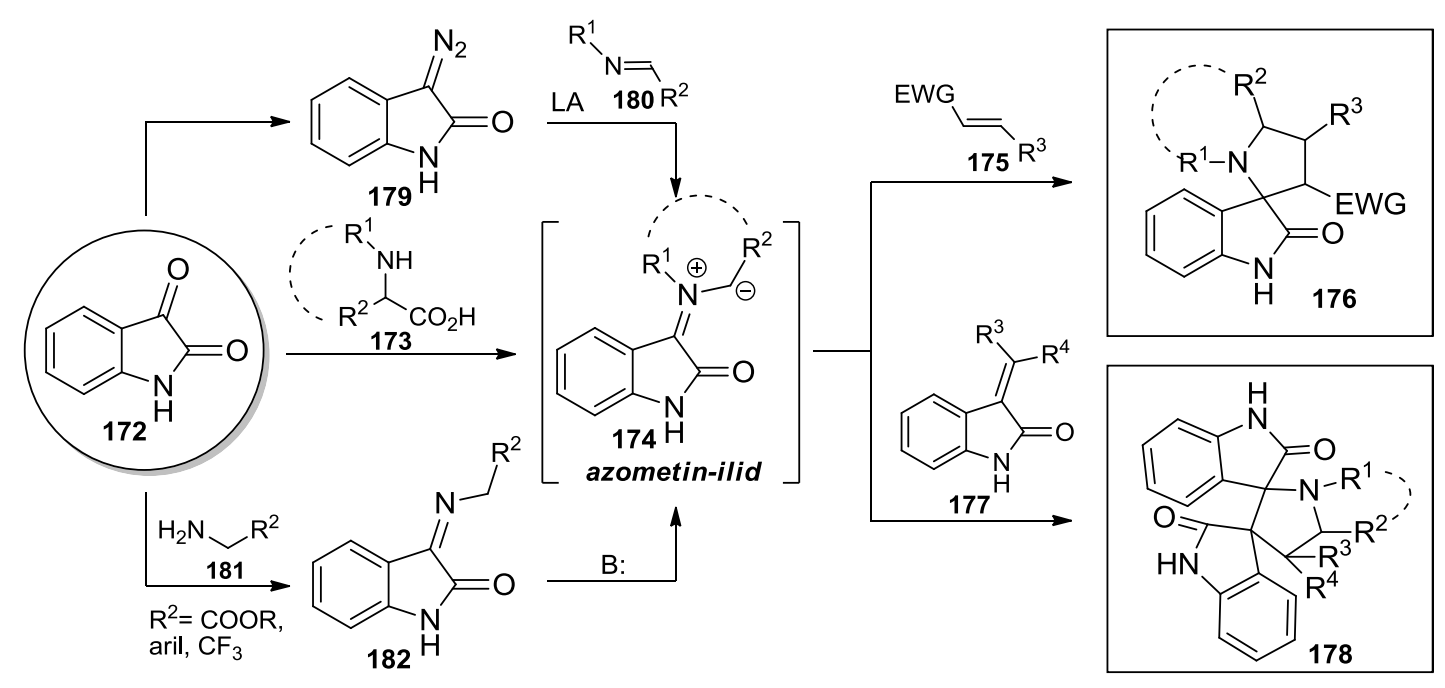

30. ábra. Spirooxindol-pirrolidinek általános előállítási módjai

Dipolarofil komponensként elektronvonzó csoporttal szubsztituált, aktivált imineket alkalmazva az előbb ismertetett szintetikus stratégiák a meglepő módon kevésbé tanulmányozott (di)spirooxindol-imidazolidinek előállitására is adaptálhatók. ${ }^{159,160,165-170}$

Az izatinból származtatott 183 ketimin a különbőző módon képzett 191 azometinilidekkel reagálva a $\mathbf{1 9 2}$ dispirooxindol-imidazolidin származékokat eredményezi (31. ábra). ${ }^{160,165,169}$ Mindhárom multikomponensủ reakció azonos regioizomerhez vezet, azonban csak az egyik eljárás („,A” reakció) biztosít teljes diasztereoszelektivitást. Megjegyzendő, hogy a termékek abszolút konfigurációját a közlemények nem, vagy nem egyértelműen ismertetik.

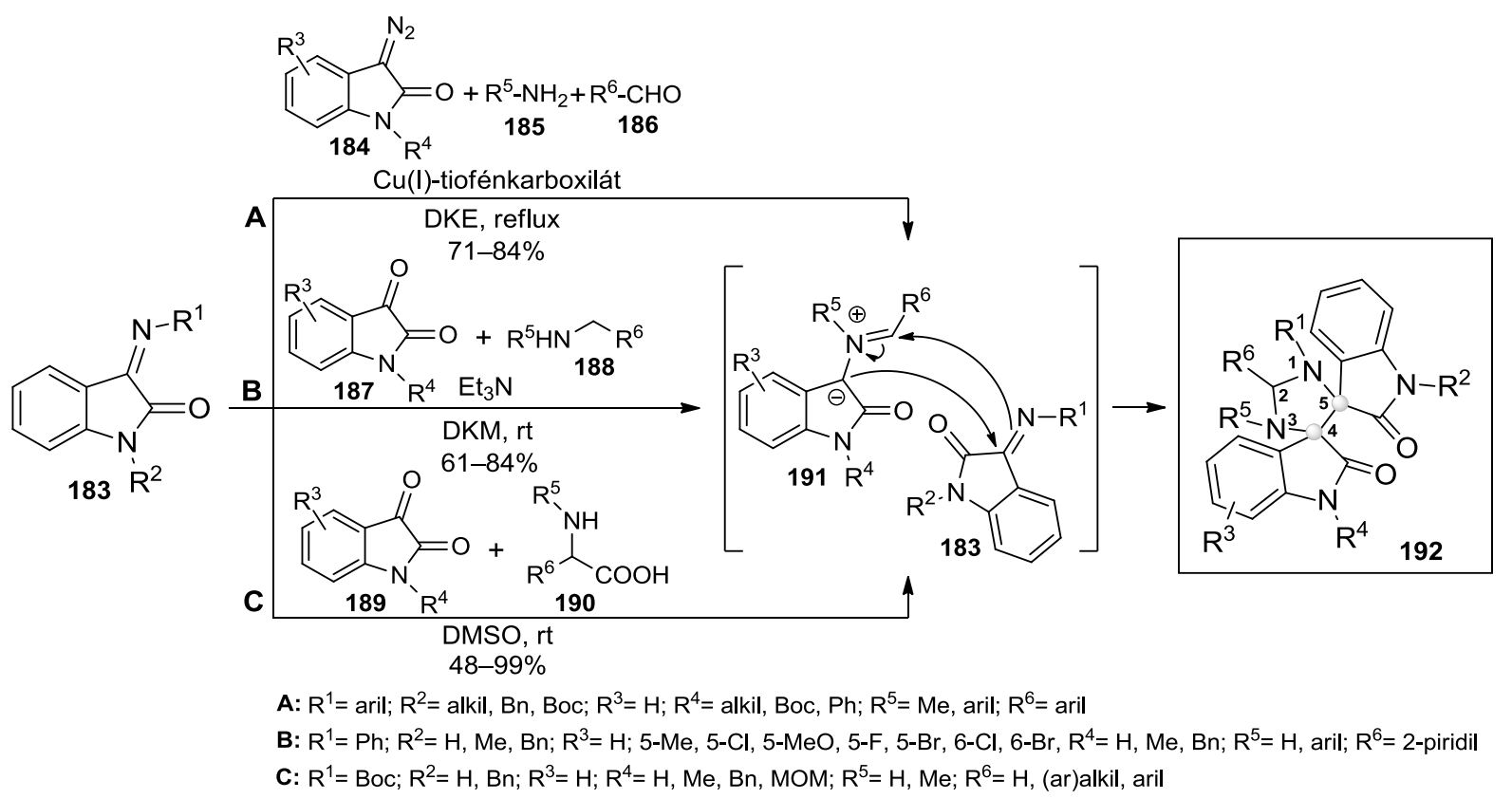

31. ábra. Dispirooxindol-imidazolidinek előállítása 
Yang és Thennarasu egyidőben fejlesztett ki egy olyan savkatalizált, 1,3-dipoláris cikloaddíción alapuló szintézismódszert, mellyel a 193 izatinok és 194 benzilaminok felhasználásával jó hozammal, teljes regio- és diaszteroszelektivitással a $( \pm)$-196 dispirooxindolimidazolidinek állíthatók elő (32. ábra). ${ }^{167,168}$ Feltételezésük szerint a cikloaddíció az izatin és amin kondenzációjából sav jelenlétében képződő 195a imin, illetve annak 1,2-prototrópia révén jelen lévő 195b azometin-ilid formája között valósul meg. A két spirooxindol molekularész az imidazolidin gyürü C-2 és C-5 pozíciójában épül ki, az előző példától eltérő regioizomert eredményezve.

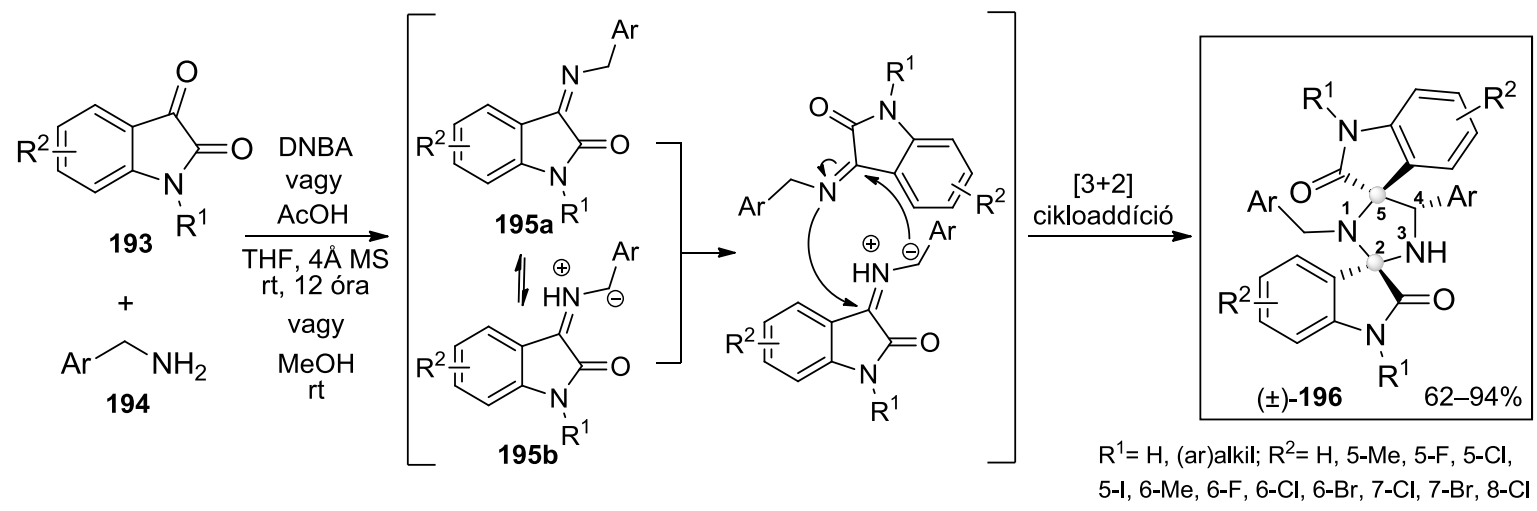

32. ábra. Regioizomer dispirooxindol-imidazolidinek előállítása

Muthusamy és kutatócsoportja a 197 diazoamid, 198 aldehid, 199 amin és 200 imin réz(I)-tiofén-2-karboxilát ( $\mathrm{Cu}(\mathrm{I}) \mathrm{TC})$ katalizált négykomponensű reakciójával, teljes kemo- és regioszelektivitással, jó hozammal a ( $( \pm)$-201 spiroindolo-imidazolidineket állította elő (33. ábra). ${ }^{159}$

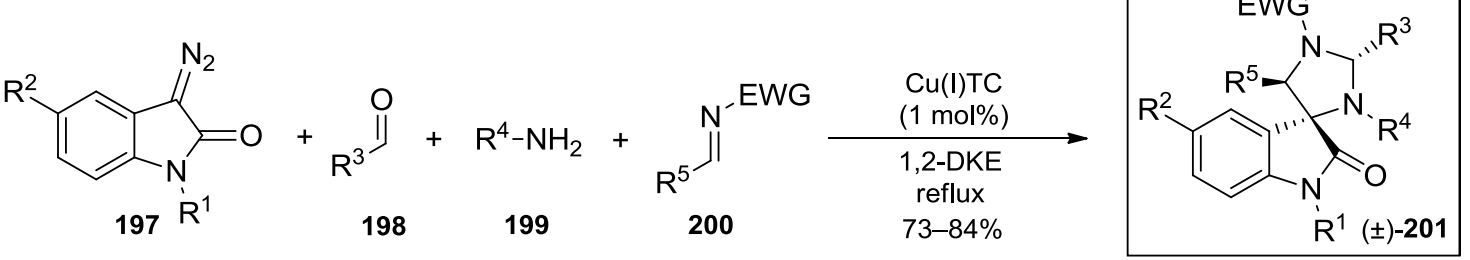

$\mathrm{R}^{1}=$ alkil, allil, Bn, Boc; $\mathrm{R}^{2}=\mathrm{H}, \mathrm{MeO}, \mathrm{Cl} ; \mathrm{R}^{3}=$ aril; $\mathrm{R}^{4}=\mathrm{Me}, \mathrm{Ph}, 4-\mathrm{Br}_{-} \mathrm{C}_{6} \mathrm{H}_{4} ; \mathrm{R}^{5}=\mathrm{Ph}, 4-\mathrm{NO}_{2}-\mathrm{C}_{6} \mathrm{H}_{4} ; \mathrm{EWG}=\mathrm{Ts}, 4-\mathrm{NO}_{2}-\mathrm{C}_{6} \mathrm{H}_{4} ; \mathrm{COOEt}$;

33. ábra. Négykomponensủ reakció spirooxindol-imidazolidinek szintézisére 
Shi és kutatócsoportja az izatinból származtatott 202 iminek, 203 aldehidek és 204 aminoészter $(R)$-205 királis foszforsav-katalizált háromkomponensü reakciójával egy olyan újfajta aszimmetrikus kemoszelektív 1,3-dipoláris cikloaddíciós módszert mutatott be, mellyel elsőként állított elő enantioszelektíven spirooxindol-imidazolidin vázegységet tartalmazó optikailag aktív vegyületeket (34. ábra). ${ }^{170}$ Meglepő módon a közepes-jó hozamokkal és magas diasztereoszelektivitással lejátszódó reakciók a nem várt 206 regioizomert szolgáltatják. A javasolt, kontroll kísérletekkel alátámasztott reakciómechanizmus első lépésében a $\mathbf{2 0 3}$ aldehid és 204 aminoészter kondenzációjával a 207a imin, illetve annak 207b azometin-ilid tautomerje keletkezik, melyek homo-1,3-dipoláris cikloaddíciója a $(R)-205$ katalizátor jelenlétében a 208 kulcsintermediert eredményezi. A 206 végtermékhez - a 207 imin/azometin-ilid képződése mellett - a 208 köztitermék és a 202 imin (R)-205 királis foszforsav katalizált enantioszelektív kaszkád reakciója vezet.

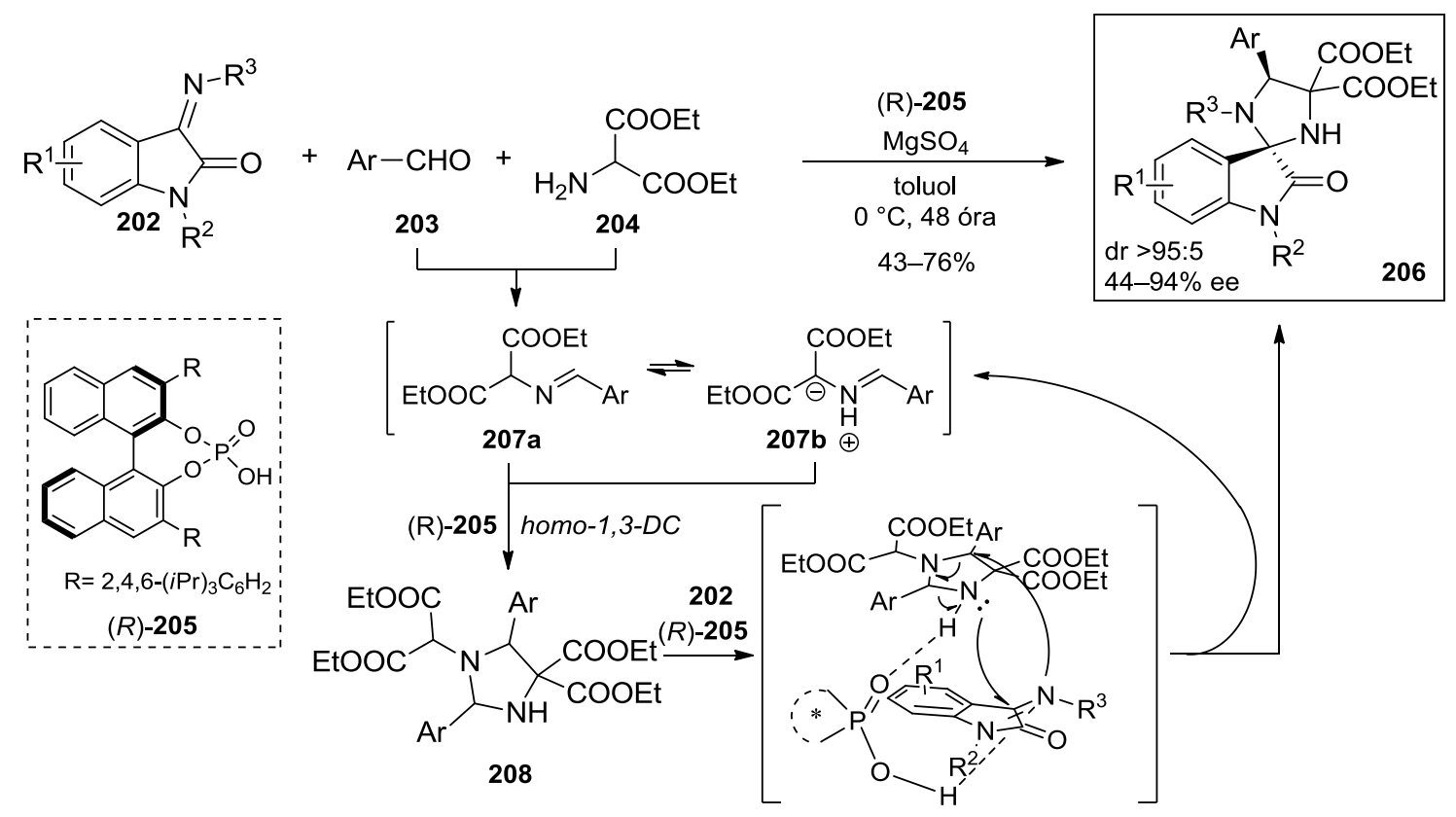

$\mathrm{R}^{1}=\mathrm{H}, 5-\mathrm{Me}, 5-\mathrm{F}, 6-\mathrm{Br}, 7-\mathrm{Me}, 7-\mathrm{F}, 7-\mathrm{Br} ; \mathrm{R}^{2}=\mathrm{Ph}, 4-\mathrm{Me}-\mathrm{Bn}, 4-\mathrm{Br}-\mathrm{Bn}, 2-\mathrm{Cl}-\mathrm{Bn}, 3-\mathrm{Cl}-\mathrm{Bn}$;

$\mathrm{R}^{3}=4-\mathrm{MeO}-\mathrm{C}_{6} \mathrm{H}_{4}, 4-\mathrm{Me}^{-} \mathrm{C}_{6} \mathrm{H}_{4}, 4-\mathrm{F}-\mathrm{C}_{6} \mathrm{H}_{4}, 4-\mathrm{PhO}-\mathrm{C}_{6} \mathrm{H}_{4}$

34. ábra. Spirooxindol-imidazolidinek aszimmetrikus előállítása 


\section{6. $2 H$-azirinek, mint imidazol prekurzorok}

Imidazolok a hagyományos szintézisstratégiák ${ }^{171,172}$ mellett a következő néhány, reakciópartnerként főként imineket felhasználó módszerrel $2 H$-azirinekből is előállíthatók. ${ }^{173}$

A $2 H$-azirinek UV-fény hatására szelektíven, a szén-szén kötés mentén nyithatók, azonban míg 230 nm-en történő besugárzással a 210 nitril-ilid képezhető, ${ }^{174-176} 350$ nm-en gerjesztve 1,4-naftalindikarbonitril (DCN) elektron-akceptor jelenlétében a 211 azaallenil gyökkation alakítható ki (35. ábra). ${ }^{177} \mathrm{Az}$ azirinek ezen tulajdonságát kihasználva Mattay és kutatócsoportja elsőként szintetizált 214 imidazol származékokat 212 2H-azirinek és 213 iminek fotokémiai reakciójával, melyet acetonitril oldószerben katalitikus mennyiségű DCN mellett valósított meg (35. ábra). ${ }^{177,178} \mathrm{~A}$ feltételezett mechanizmus szerint először a 212 azirin-ből DCN-nel in situ képzett 215 2-azaallenil gyökkation cikloaddíciós reakcióba lép a 213 iminnel, majd a képződött 216 dihidroimidazol gyökkation egy újabb elektrontranszfer és aromatizáció révén a 214 terméket szolgáltatja. Érdemes megemlíteni, hogy ez az egyetlen olyan szintézismódszer, mellyel az imidazol C-2 szubsztituensét $\left(\mathrm{R}^{2}\right)$ az azirin határozza meg.

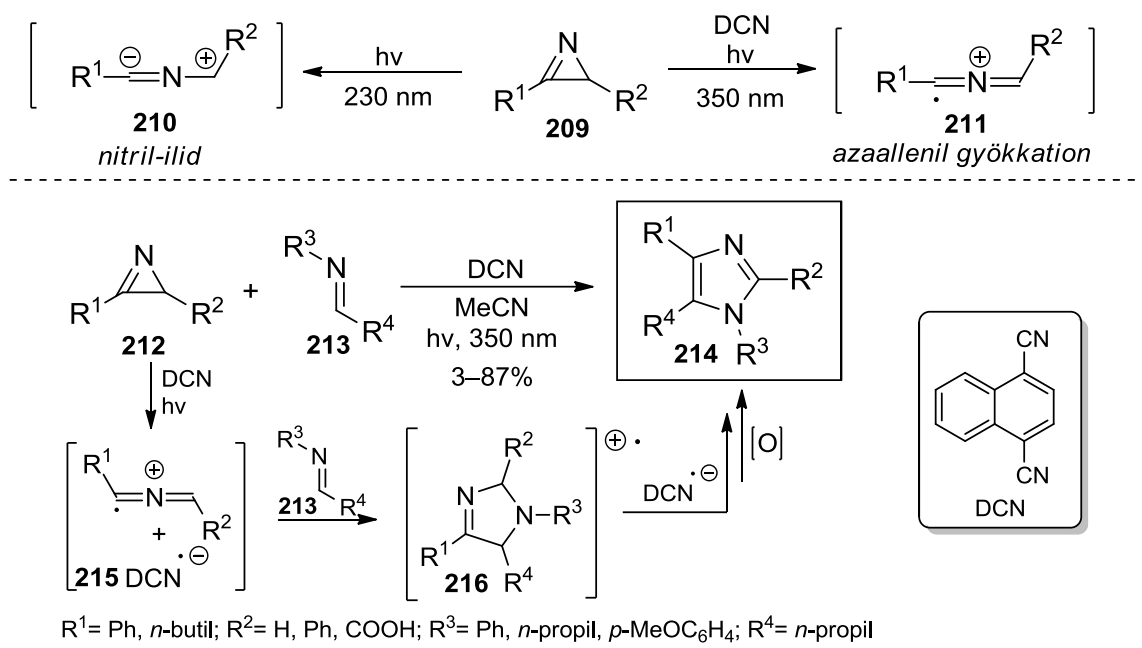

35. ábra. Imidazolszintézis $2 H$-azirinek és iminek fotokémiai reakciójával

A $2 H$-azirinek és iminek reakciója Lewis-savakkal is elősegíthető, azonban az alkalmazott promóter kémiai minősége a reakció kimenetelét nagymértékben befolyásolja. Míg a 217 azirin és 218 imin $\mathrm{FeCl}_{2}$ vagy $\mathrm{FeCl}_{3}$ katalizált reakciója - az azirin C-N kötésének homolitikus hasadásával induló gyökös mechanizmuson keresztül (36. ábra, A út) - a 219, illetve - az azirin klasszikus aktiválásán alapuló ionos mechanizmuson keresztül (36. ábra, B út) - a 220 regioizomerek keverékét eredményezi, addig $\mathrm{AlCl}_{3}, \mathrm{ZnCl}_{2}, \mathrm{ZnBr}_{2}$ vagy $\mathrm{Zn}(\mathrm{OTf})_{2}$ jelenlétében kizárólag a 220 termék keletkezik. ${ }^{179,180}$ 


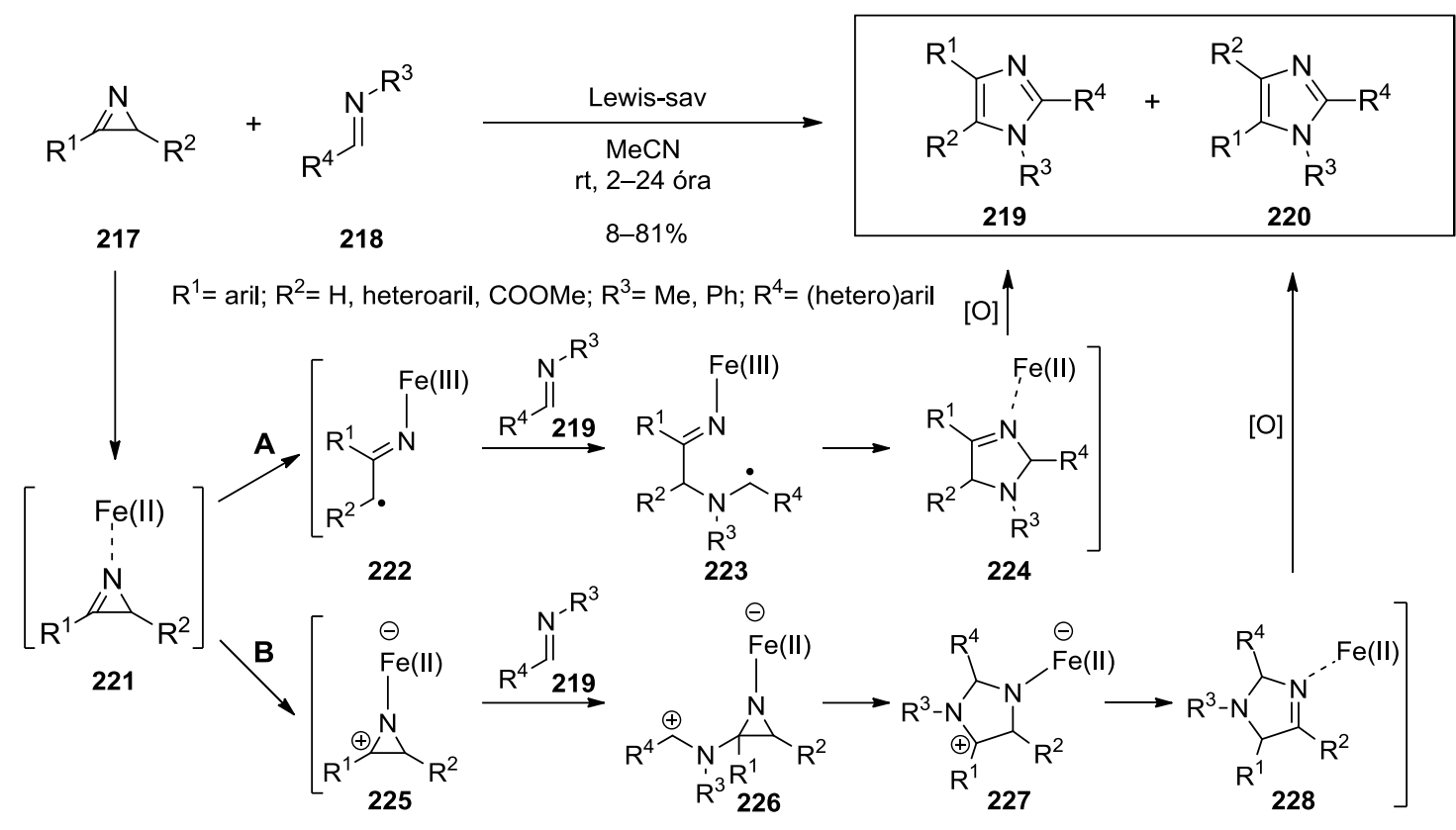

36. ábra. Imidazolszintézis $2 H$-azirinek és iminek Lewis-sav katalizált reakciójával

Multiszubsztituált imidazolok $2292 H$-azirinek, 230 aminok és 231 aldehidek háromkomponensű reakciójával is előállíthatók (37. ábra). ${ }^{181} \mathrm{Az}$ in situ iminképzésen alapuló módszer kísérleti úton igazolt érdekessége, hogy a 229 azirin és 234 imin reakcióját az aminkomponens a $\mathbf{2 3 3}$ addukt képződésén keresztül katalizálja. A nagyfokú diverzitást és teljes regioszelektivitást biztosító eljárás hátránya, hogy kizárólag erős nukleofil karakterü aminok alkalmazhatók, így a reakció anilinszármazékokkal nem megy végbe.

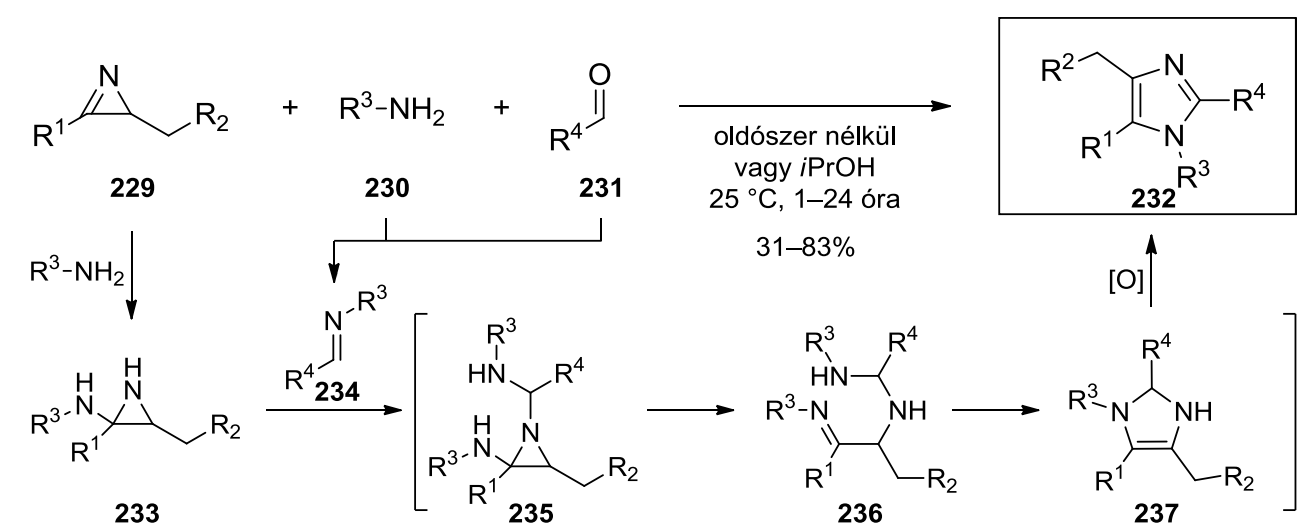

$\mathrm{R}^{1}=\mathrm{Ph}, \mathrm{Et} ; \mathrm{R}^{2}=\mathrm{COOMe}, \mathrm{OH} ; \mathrm{R}^{3}=\mathrm{Bn}$, allil, $n$-butil; $N$-COOEt-piperidin-4-il; 2-(indol-3-il)-etil; $\mathrm{R}^{4}=$ (hetero)aril, etil

37. ábra. Imidazolszintézis $2 H$-azirinek, aminok és aldehidek háromkomponensủ reakciójával

Tiwari és Mauyra a korábban már ismertetett fotokaszkád katalízist (19. oldal) a 240 imidazol származékok előállítására is kiterjesztette (38. ábra). ${ }^{182} \mathrm{Az}$ áramlásos mikroreaktorban megvalósított reakció kulcslépése a 241 imin 238 szekunder aminból, illetve a $2422 H$-azirin 239 
vinil-azidból, látható fény/[Ru(bpy $\left.)_{3}\right]\left[\left(\mathrm{PF}_{6}\right)_{2}\right] / \mathrm{TPHP}$ fotoredox rendszer segítségével történő in situ képzése, melyek addíciós reakciója, majd a keletkező 245 imidazolin intermedier oxidációja vezet a $\mathbf{2 4 0}$ imidazolokhoz. A szerzők egy másik közleményben a $\mathbf{2 4 0}$ imidazolok hagyományos, szakaszos (lombikban végrehajtott) szintézisét is ismertették, oxidálószerként $\mathrm{Ag}_{2} \mathrm{CO}_{3}$-ot alkalmazva (toluol, $90{ }^{\circ} \mathrm{C}, 12$ óra, 65-95\%). ${ }^{183}$<smiles>[R]C=C(N)C([R])=O</smiles>

238<smiles>[Te][Te]</smiles><smiles>c1ccc2c(c1)CCN1CCCC21</smiles>

241

242

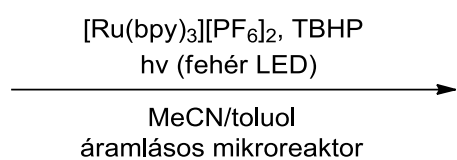

$35-72 \%$

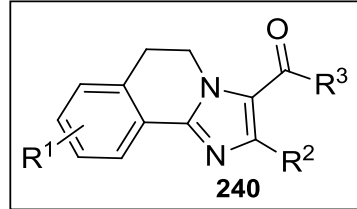

ox.

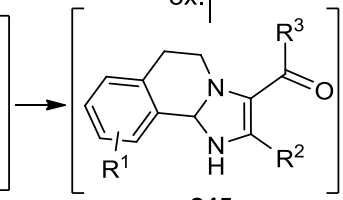

245

243

$R^{1}=H$, 4-diMeO; $R^{2}=H$, propil, aril, furil; $R^{3}=$ aril

38. ábra. $2 H$-azirinek és iminek in situ képzésén alapuló fotokaszkád katalízis imidazolok szintézisére

Az azirinen keresztüli imidazolszintézisre egy további példa a 246 vinil-azidok és 247 benzilaminok jódkatalizált oxidatív tandem-ciklizációs reakciója, mellyel a $\mathbf{2 4 8}$ aromás csoportokkal triszubsztituált imidazolok nyerhetők (39. ábra). ${ }^{184}$ A szerzők feltételezése szerint a vinil-azid termikus bomlásából képződő 249 azirin a benzilamin származék oxidációjából keletkező 251 iminnel közvetett úton, a 250 addukton keresztül lép reakcióba. A létrejövő 252 intermedier oxidációját követően ammónia távozása közben intramolekuláris ciklizáció szolgáltatja a 248 végterméket.

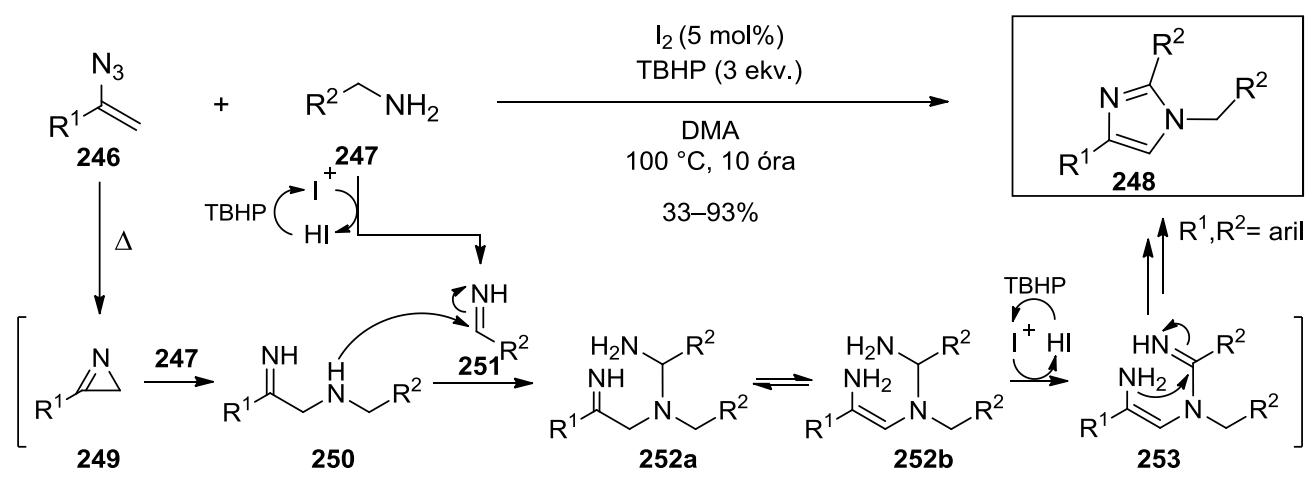

39. ábra. $2 H$-azirinek és iminek in situ képzésén alapuló jódkatalizált oxidatív imidazolszintézis

Opatz és kutatócsoportja egy kétlépéses, egyedényes módszert fejlesztett ki tetraszubsztituált imidazolok előállítására, mely az előző két példához hasonlóan az azirin és imin reakciópartnerek in situ generálásán alapul. ${ }^{185}$ Az eljárás első lépésében a 254 -aminonitril és 
255 aldehid komponensek kondenzációjával a 258 imin, míg a második lépésben a 256 izoxazol UV-fény indukált izomerizációjával a $\mathbf{2 6 0}$ acilazirin kialakítása történik (40. ábra). Az imin deprotonálódását követően nukleofil addíció, gyürüzárás, majd a 263 intermedier aziridin gyürüjének felnyílása eredményezi a 257 végterméket. Megjegyzendő, hogy ezzel a szintézismódszerrel az imidazol kiépítése oxidálószert nem igényel, mivel a megfelelő oxidációs állapot az elegánsan megválasztott, $\mathrm{CN}$ távozó csoporttal szubsztituált amin/imin révén biztosított. Az eljárás főleg aromás csoportokkal szubsztituált imidazolok előállítására alkalmas.

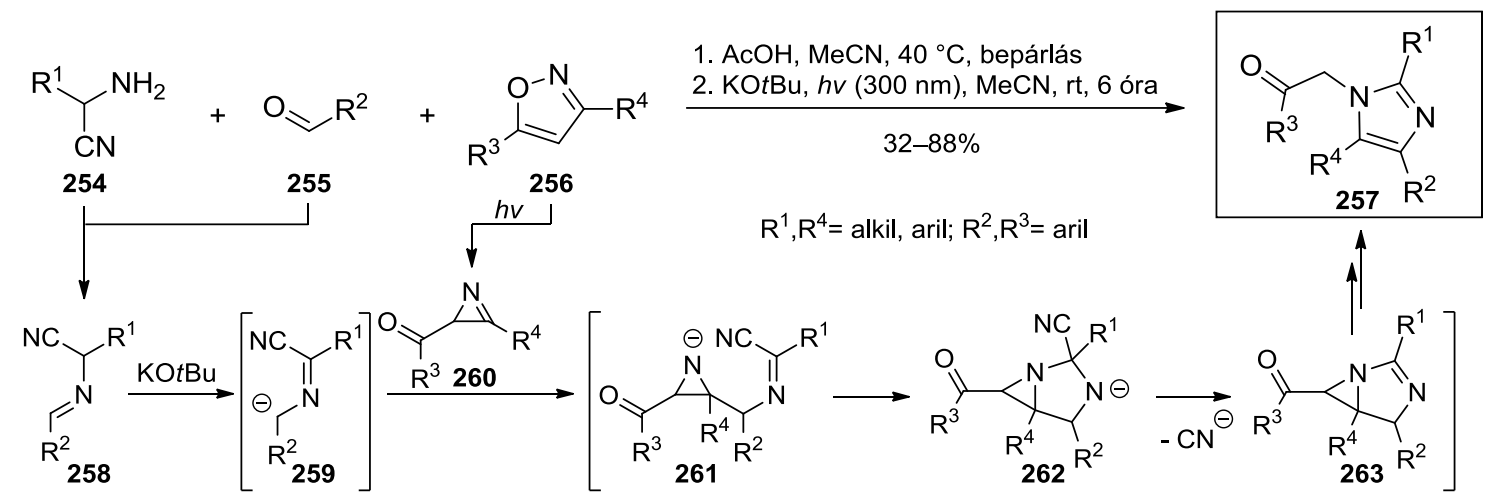

40. ábra. $2 H$-azirinek és iminek in situ képzésén alapuló háromkomponensủ imidazolszintézis

Az eddig ismertetett szintetikus stratégiák mellett imidazolok $2 H$-azirinek és imidátok reakciójával is előállíthatók (41. ábra). ${ }^{186,187}$ A Ding és kutatócsoportja által ismertetett $\mathrm{ZnCl}_{2}$ katalizált módszer során először feltételezhetően a 267 aktivált azirin képződik, melyből az imidát addícióját követően az etoxicsoport távozásával járó intramolekuláris nukleofil szubsztitúció és az aziridin gyürü felnyílása vezet a $266 N$-szubsztituálatlan imidazol végtermékhez. A reakció monoszubsztituált $\left(\mathrm{R}^{2}=\mathrm{H}\right)$ és szimmetrikusan diszubsztituált $\left(\mathrm{R}^{1}=\mathrm{R}^{2}=\mathrm{Ph}\right)$ azirinekkel teljes regioszelektivitást biztosít, azonban nem szimmetrikusan diszubsztituált azirinek regioizomer termékelegyet eredményeznek.

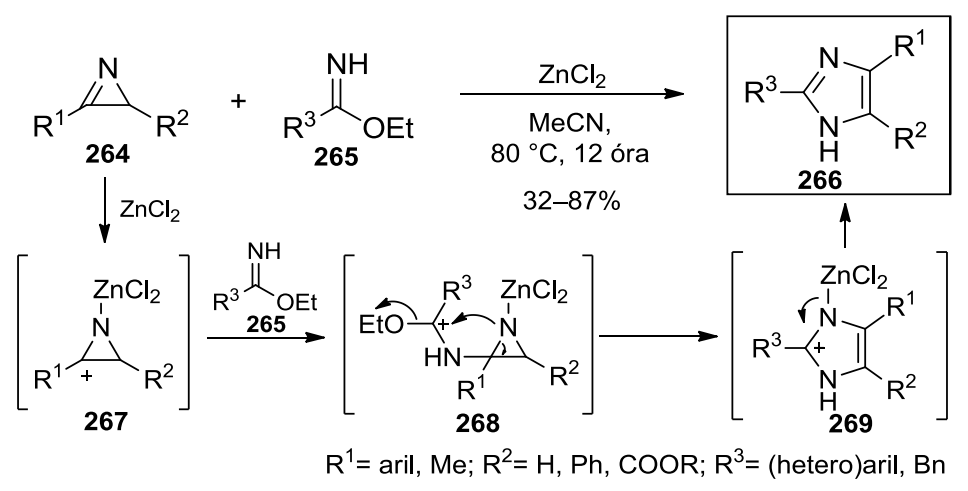

41. ábra. Imidazolszintézis $2 H$-azirinek és imidátok $\mathrm{ZnCl}_{2}$-katalizált reakciójával 


\section{Célkitüzés}

Doktori munkám célja a $2 H$-azirinek elektrofil és dipolarofil tulajdonságait kihasználó korábban ismeretlen reakcióinak megvalósítása volt. Olyan új szintézismódszerek kidolgozására és optimalizálására törekedtünk, mellyel nagy diverzitású és tetszőleges szubsztitúciós mintázatú heterociklusos vegyületkönyvtárak építhetők fel.

Elsőként az Ugi-Joullié háromkomponensű reakció $2 H$-azirinekre történő kiterjesztésével multiszubsztituált $N$-acilaziridin-2-karboxamidok egylépéses, diasztereoszelektív előállítását terveztük megvalósítani (42. ábra, A). Ezt követően a $2 H$-azirinek 1,3-dipoláris cikloaddíciós reakcióit kívántuk vizsgálni oxindol-alapú azometin-ilid és nitron dipólokkal. Az azometinilideket izatinok és $\alpha$-aminosavak reakciójával in situ terveztük elöállítani egy olyan háromkomponensű szintézis részlépéseként, amellyel egy új aziridinnel kondenzált spirooxindol-imidazolidin vázrendszer kialakulását vártuk (42. ábra, B). A $2 H$-azirinek és nitronok reakciójával egy az irodalomban még ismeretlen biciklust kívántuk előállítani, azonban a kezdeti eredmények egy új imidazolszintézis lehetőségét vetették fel (42. ábra, C).

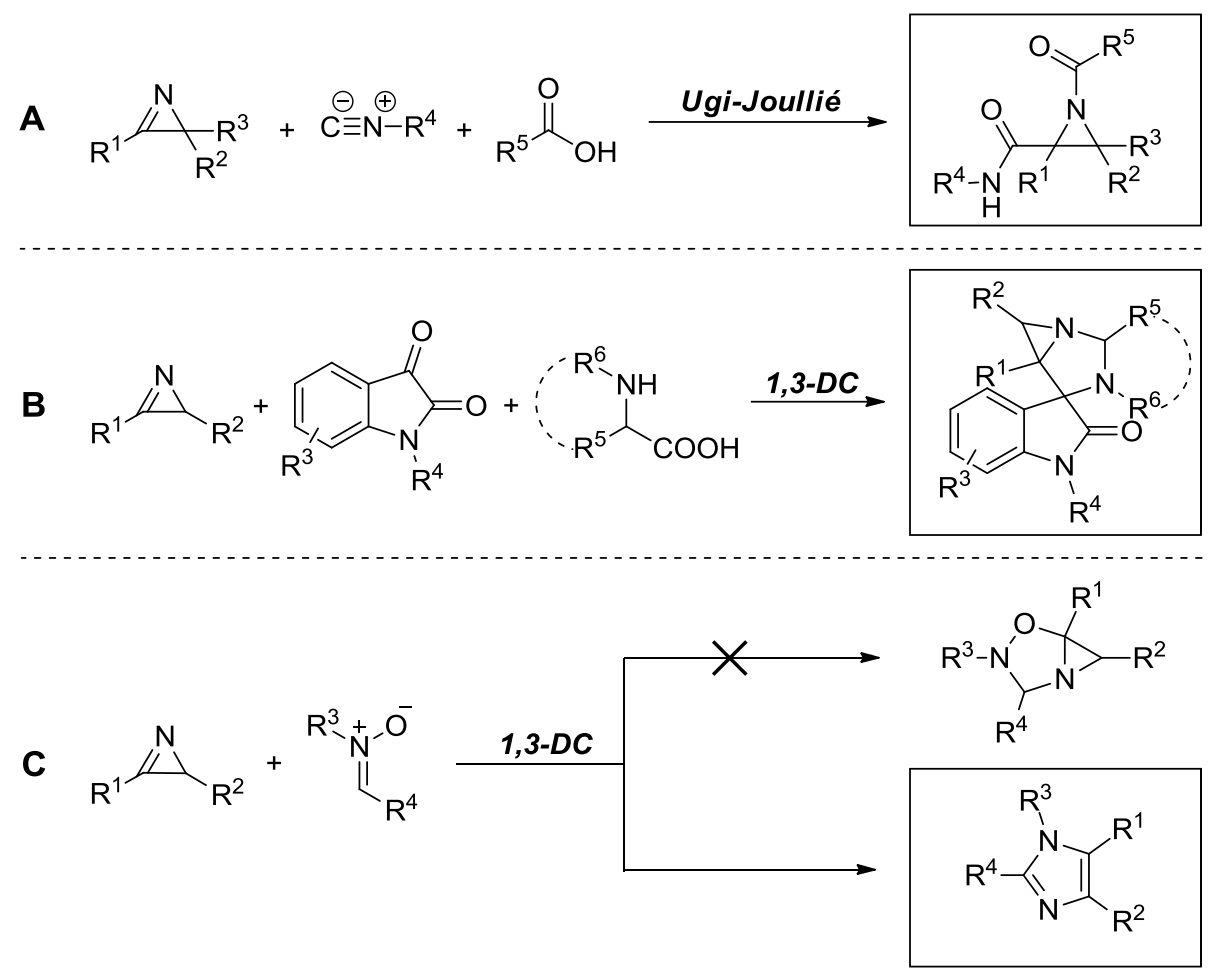

42. ábra. $2 H$-azirinek tervezett, korábban ismeretlen átalakításai

További célunk volt az előállított vegyületek szerkezetének nagymüszeres analitikai módszerekkel (NMR, HRMS) történő igazolása, valamint a reakciók sztereo- és regioszelektivitásának vizsgálata. 


\section{Kísérleti eredmények tárgyalása}

\subsection{Kiindulási $2 H$-azirinek szintézise}

A kísérleti munka során felhasznált kiindulási $( \pm)$-270a-j azirineket szubsztituáltságuk alapján ((i) alifás, (ii) aromás és (iii) C-2-es pozícióban szubsztituálatlan azirin) három eltérő, módosított irodalmi $^{188-192}$ szintézisstratégiát alkalmazva állítottuk elő. Megjegyzendő, hogy a $( \pm)-270 c$ és $( \pm)$-270d triszubsztituált analógokat az irodalomban elsőként szintetizáltuk.

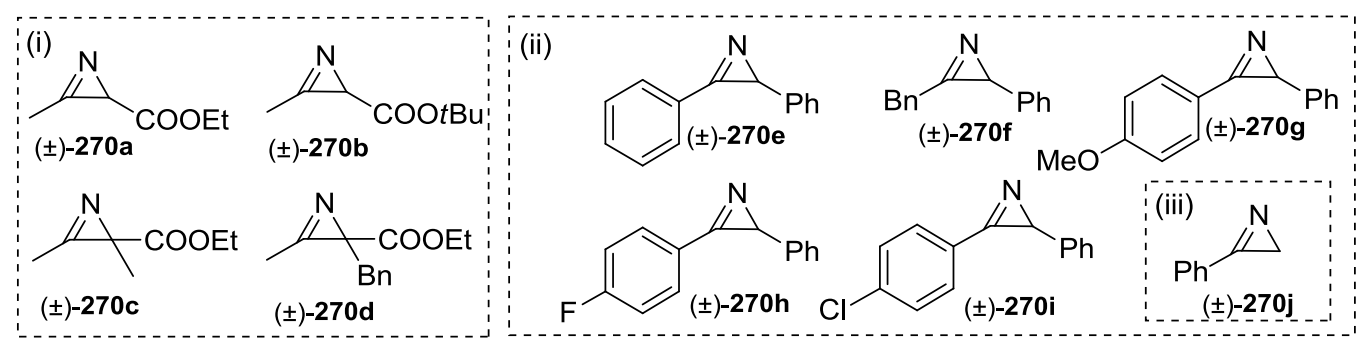

43. ábra. A kísérleti munka során felhasznált $2 H$-azirinek

A ( \pm )-270a-c $2 H$-azirin-2-karboxilátok szintéziséhez a kereskedelmi forgalomban elérhető 271a-c észterekből indultunk ki (44. ábra). A ( \pm )-270d analóg 271d kiindulási vegyületét etil-acetoacetát és benzil-bromid reakciójával nyertük. ${ }^{193}$ A 271 észtereket hidroxilaminnal a 272a-d ketoximokká alakítottuk, melyekből tozil-klorid hozzáadásával piridin jelenlétében a 273a-d ketoxim-tozilátokat képeztük. Ezt követően megfelelő erősségü bázis hozzáadásával (TEA vagy DBU) alakítottuk ki a gyürüzárt céltermékeket, melyeket vákuumdesztillációs $(( \pm)-\mathbf{2 7 0 a}-\mathbf{c})$ vagy oszlopkromatográfiás $(( \pm)-270 d)$ módszerrel izoláltunk. ${ }^{188,189}$

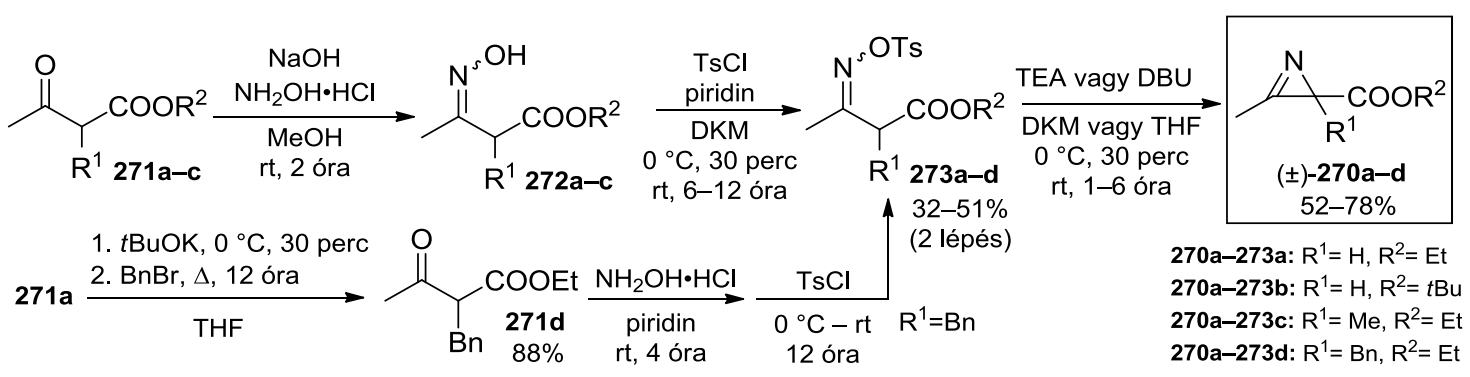

44. ábra. Alifás $2 H$-azirin-2-karboxilátok szintézise

Aromás azirinek esetében először a 274a-e ketonokból a 275a-e oximokat képeztük, majd extrakciós tisztítást követően a nyers reakcióelegyekhez metán-szulfonil-kloridot és trietilamint adtunk, melyet 30 perc kevertetés után újabb bázis, DBU hozzáadása követett (45. ábra). ${ }^{190} \mathrm{~A}( \pm)-\mathbf{2 7 0 e - i}$ azirineket oszlopkromatográfiás eljárással nyertük. 


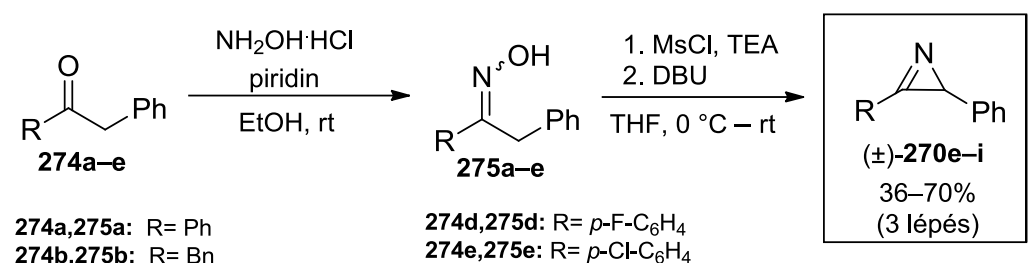

274b,275b: $\mathrm{R}=\mathrm{Bn} \quad$ 274e,275e: $\mathrm{R}=p-\mathrm{Cl}_{-} \mathrm{C}_{6} \mathrm{H}_{4}$

274c, 275c: $\mathrm{R}=p-\mathrm{MeO}-\mathrm{C}_{6} \mathrm{H}_{4}$

45. ábra. Aromás $2 H$-azirinek szintézise

A 3-fenil-2H-azirin $(( \pm)-\mathbf{2 7 0 j})$ előállítását sztirolból (276) végeztük, melyet először brómozással sztirol-dibromiddá (277) alakítottunk (46. ábra). ${ }^{191}$ Ezt követően nátrium-aziddal a 278 azidosztirolt képeztük, amely két órás forralást követően nitrogén távozása közben szolgáltatta a kívánt terméket, melyet végül vákuumdesztillációs eljárással izoláltunk.

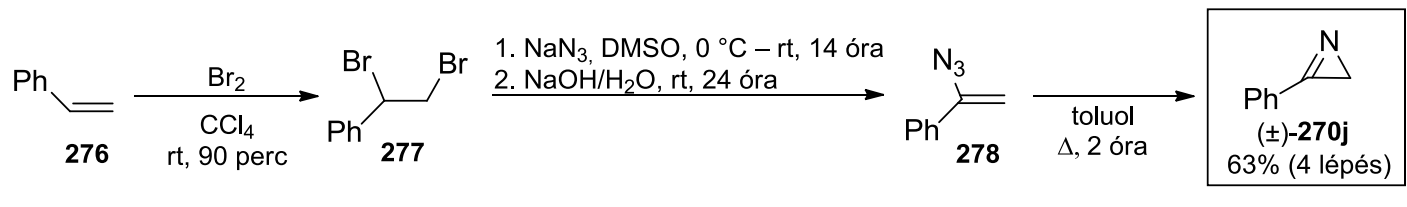

46. ábra. 3-Fenil-2H-azirin szintézise

Továbbá egy sztöchiometrikus mennyiségü kinidin jelenlétében, vízmentes toluolban, 0 ${ }^{\circ} \mathrm{C}$-on megvalósított aszimmetrikus szintézissel az etil-3-metil-2H-azirin-2-karboxilát optikailag aktív formáját $((-)-(R)-\mathbf{2 7 0 a})$ is előállítottuk, melyet 18\%-os hozammal, 72\%-os enantioszelektivitással sikerült izolálnunk (47. ábra). ${ }^{192}$
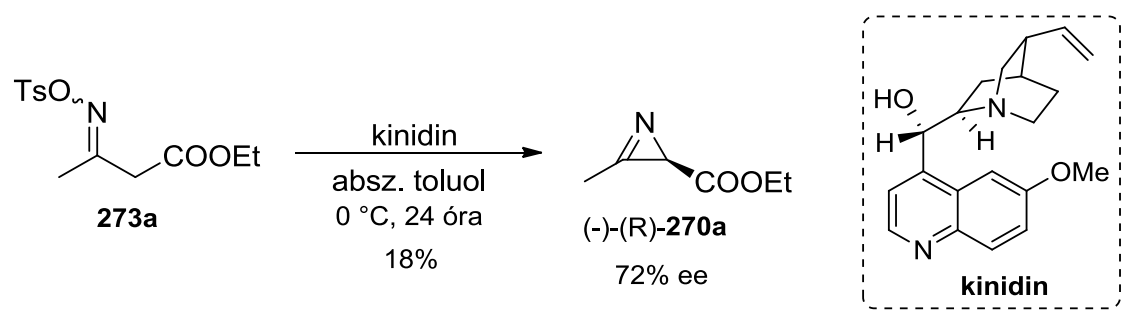

47. ábra. Optikailag aktív 270a $2 H$-azirin szintézise

\section{2. $N$-acilaziridin-2-karboxamidok szintézise ${ }^{194}$}

Az $N$-acilaziridinek szintézisére irányuló kísérleti munka első részében az ( \pm )-etil-3-metil-2Hazirin-2-karboxilát $(( \pm)-270 a)$, terc-butil-izocianid (279a) és benzoesav (280a) reakcióját tanulmányoztuk az irodalomban ismert Ugi-Joullié-3CR általános reakciókörülményei között (MeOH, toluol; rt, majd forralás). ${ }^{49,54}$ Mivel konverziót nem tapasztaltunk, így további oldószereket teszteltünk; THF-ban két nap forralást követően két Ugi-Joullié termék, a $\mathbf{2 8 1}\{1\}$ 
transz- és $( \pm) 282-\{1\}$ cisz- $N$-acilaziridin-2-karboxamid alacsony hozamú képződését figyeltük meg (1. táblázat, 1. kísérlet). Figyelembe véve, hogy az azirinek reaktivitását a Lewis-savak növelhetik, a modellreakcióban számos Lewis- és Brønsted-savat teszteltünk (1. táblázat, 2-18. kísérlet). A reakciókat HPLC-vel követtük, az egyes hozamokat az izolált ( \pm )-281 $\{1\}$ és $( \pm) \mathbf{2 8 2}$ \{1\} termékek kalibrációja révén határoztuk meg. Az alkalmazott katalizátorok többsége hatástalannak bizonyult (1. táblázat, 2-10. kísérlet) vagy alacsony-közepes aktivitást mutatott (1. táblázat, 11-17. kísérlet). Ezzel szemben a $\mathrm{ZnCl}_{2}$ kimagaslónak bizonyult, a kívánt $( \pm)-\mathbf{2 8 1}\{1\}$ és ( \pm -282\{1\} N-acilaziridineket 71\%-os összesített HPLC-hozammal szolgáltatta (1. táblázat, 18. kísérlet). A katalizátor mennyiségét változtatva (növelve vagy csökkentve) a hozam csökkenését figyeltünk meg, így az optimális katalizátor mennyiséget $25 \mathrm{~mol} \%$-ban állapítottuk meg (1. táblázat, 19. és 20. kísérlet). Emellett megfigyeltük, hogy a diasztereomer arányt sem a katalizátor minősége, sem a mennyisége jelentősen nem befolyásolja, a reakciók magas diasztereoszelektivitással a $( \pm)$-281 $\{1\}$ transz-aziridin termékhez vezetnek (87:13-94:6 dr).

1. táblázat. Lewis- és Brønsted-savak hatása az Ugi-Joullié modellreakcióra

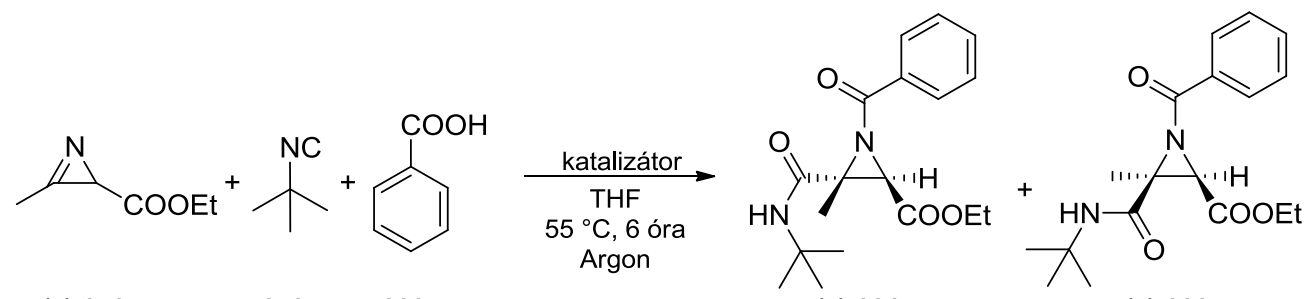

$( \pm)-270 a$

$279 a \quad 280 a$

$( \pm)-281\{1\}$

$( \pm)-282\{1\}$

\begin{tabular}{llll|llll}
\hline Kísérlet & Katalizátor & $\begin{array}{l}\text { Hozam } \\
(\mathbf{\%})^{\boldsymbol{a}}\end{array}$ & $\begin{array}{l}\mathbf{d r} \\
(\text { transz:cisz })^{\boldsymbol{b}}\end{array}$ & Kísérlet & Katalizátor & $\begin{array}{l}\text { Hozam } \\
(\mathbf{\%})^{\boldsymbol{a}}\end{array}$ & $\begin{array}{l}\mathbf{d r} \\
(\text { transz:cisz })^{\boldsymbol{b}}\end{array}$ \\
\hline $1^{c}$ & - & $8^{d}$ & $93: 7$ & 11 & $\mathrm{SnCl}_{2}$ & 12 & $92: 8$ \\
2 & $\mathrm{PTSA}$ & 0 & - & 12 & $\mathrm{FeCl}_{3}$ & 13 & $92: 8$ \\
3 & $\mathrm{HClO}_{4}$ & 0 & - & 13 & $\mathrm{In}(\mathrm{OAc})_{3}$ & 16 & $88: 12$ \\
4 & $\mathrm{In}(\mathrm{OTf})_{3}$ & 0 & - & 14 & $\mathrm{Zn}(\mathrm{OAc})_{2}$ & 20 & $90: 10$ \\
5 & $\mathrm{Mg}(\mathrm{OTf})_{2}$ & 0 & - & 15 & $\mathrm{ZnO}$ & 23 & $87: 13$ \\
6 & $\mathrm{Dy}(\mathrm{OTf})_{3}$ & 0 & - & 16 & $\mathrm{InCl}_{3}$ & 51 & $94: 6$ \\
7 & $\mathrm{InF}_{3}$ & 0 & - & 17 & $\mathrm{ZnBr}_{2}$ & 56 & $92: 8$ \\
8 & $\mathrm{CuBr}_{2}$ & 0 & - & $\mathbf{1 8}$ & $\mathbf{Z n C l}_{2}$ & $\mathbf{7 1}$ & $\mathbf{9 3 : 7}$ \\
9 & $\mathrm{CuCl}_{2}$ & 0 & - & 19 & $\mathrm{ZnCl}_{2}{ }^{e}$ & 61 & $93: 7$ \\
10 & $\mathrm{AlCl}_{3}$ & 0 & - & 20 & $\mathrm{ZnCl}_{2}{ }^{f}$ & 54 & $94: 6$ \\
\hline
\end{tabular}

Reakciókörülmények: $2 H$-azirin (0,25 mmol), terc-butil-izocianid (1,1 ekv.), benzoesav (1,1 ekv.), vízmentes THF (0,5 ml), katalizátor $(25 \mathrm{~mol} \%)$, argon, $55^{\circ} \mathrm{C}, 6$ óra.

${ }^{[a]}$ A $281\{1\}$ és $\mathbf{2 8 2}\{1\}$ izomerek összesített hozama, melyet HPLC-vel határoztunk meg. ${ }^{[b]}$ A diasztereomer arányt (dr) HPLCvel határoztuk meg (23\{1\} és $\mathbf{2 4}\{1\}$ kalibrációjával). ${ }^{[\mathrm{c}]} 48$ óra, forralás. ${ }^{[\mathrm{d}]}$ Izolált hozam. ${ }^{[\mathrm{e}]} 10 \mathrm{~mol} \%$ katalizátor mellett. ${ }^{[\mathrm{fl}} 50$ mol\% katalizátor mellett. 
A $( \pm)-\mathbf{2 8 1}\{1\}$ és $( \pm)-\mathbf{2 8 2}\{1\}$ diasztereomerek szerkezetét egydimenziós- $\left({ }^{1} \mathrm{H}-\mathrm{NMR}\right.$ és ${ }^{13} \mathrm{C}-\mathrm{NMR}$ ) és kétdimenziós NMR spektroszkópiai eljárásokkal (HSQC, HMBC és NOESY) igazoltuk. Az NMR adatok alapján a két termék ${ }^{1} \mathrm{H}$ - és ${ }^{13} \mathrm{C}-\mathrm{NMR}$ spektrumán teljes jelhozzárendelést végeztünk (48. és 49. ábra). A $( \pm)-281\{1\}$ modellvegyület esetében az alifás tartományban 0,96 ppm-nél található szingulett jel a terc-butil-izocianid (4'-C( $\left.\left.\mathrm{CH}_{3}\right)_{3}\right)$, míg az aromás tartományban 7,4-7,8 ppm között lévő jelek a benzoesav egység (5"-CH: 7,56 ppm, t; 3"-CH: 7,73 ppm, d; 4"-CH 7,46 ppm, t) beépülését jelzik (48. ábra). Emellett az aziridin vázrendszerhez tartozó $\mathrm{CH}-\left(3,53\right.$ ppm, s) és $\mathrm{CH}_{3}(1,71 \mathrm{ppm}, \mathrm{s})$ funkció, valamint az etilészter $\mathrm{CH}_{2^{-}}(4,20 \mathrm{ppm}, \mathrm{q})$ és $\mathrm{CH}_{3^{-}}(1,23 \mathrm{ppm}, \mathrm{t})$ jelei is egyértelműen azonosíthatók. A ${ }^{13} \mathrm{C}-\mathrm{NMR}$ spektrumban a fent említett részegységekhez tartozó jeleken túl a karbonilcsoportok jeleit (C-1": 174,8 ppm; C-4: 166,7 ppm; C-1': 164,5 ppm) is azonosítottuk. A minor ( \pm -282\{1\} terméknél is megtalálhatók az említett alegységek szignáljai, csupán a kémiai eltolódásokban található különbség (49. ábra).
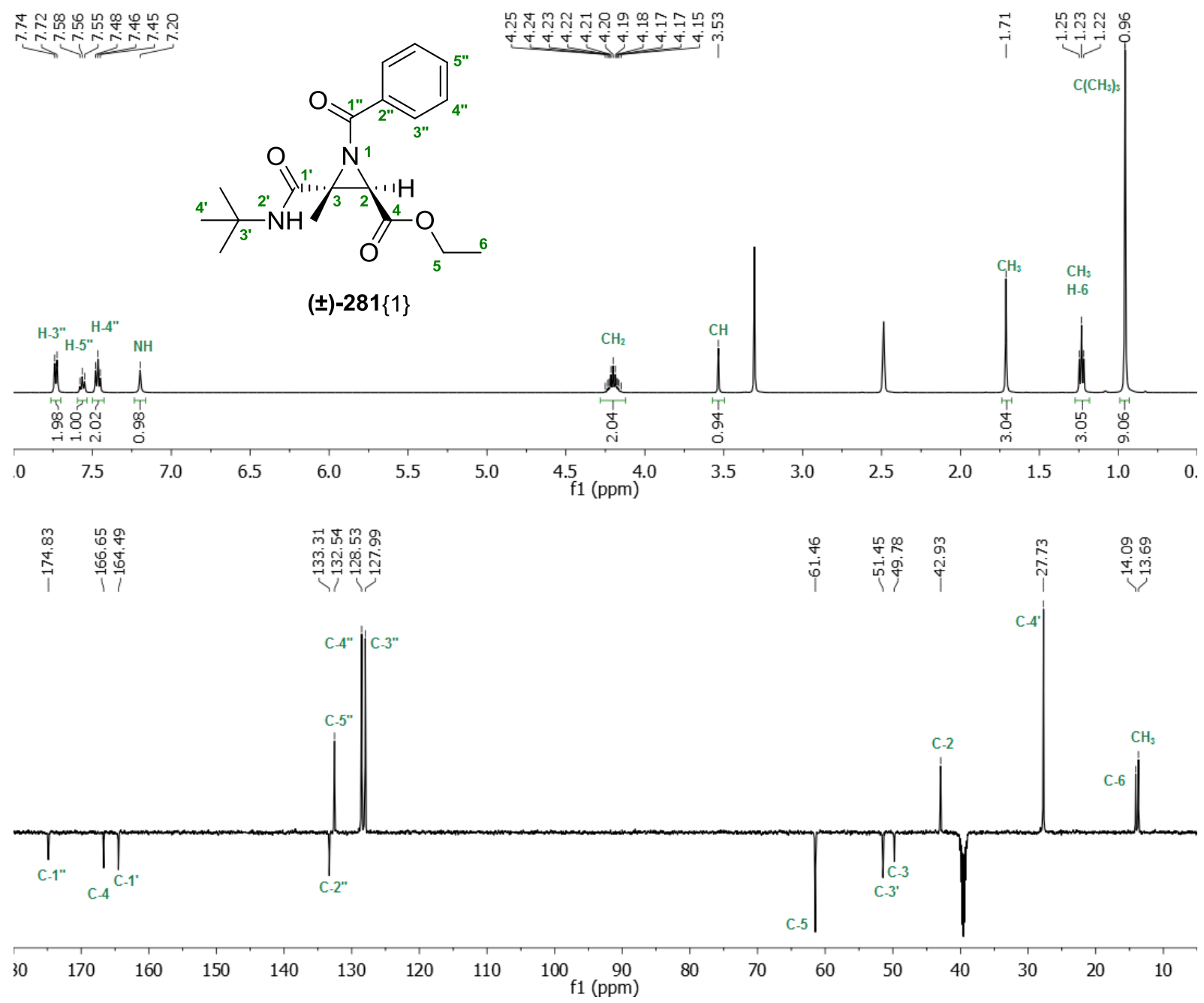

48. ábra. A ( \pm )-281 $\{1\}$ vegyület ${ }^{1} \mathrm{H}$ - és ${ }^{13} \mathrm{C}-\mathrm{NMR}$ spektrumai (DMSO- $d_{6}$ ) 


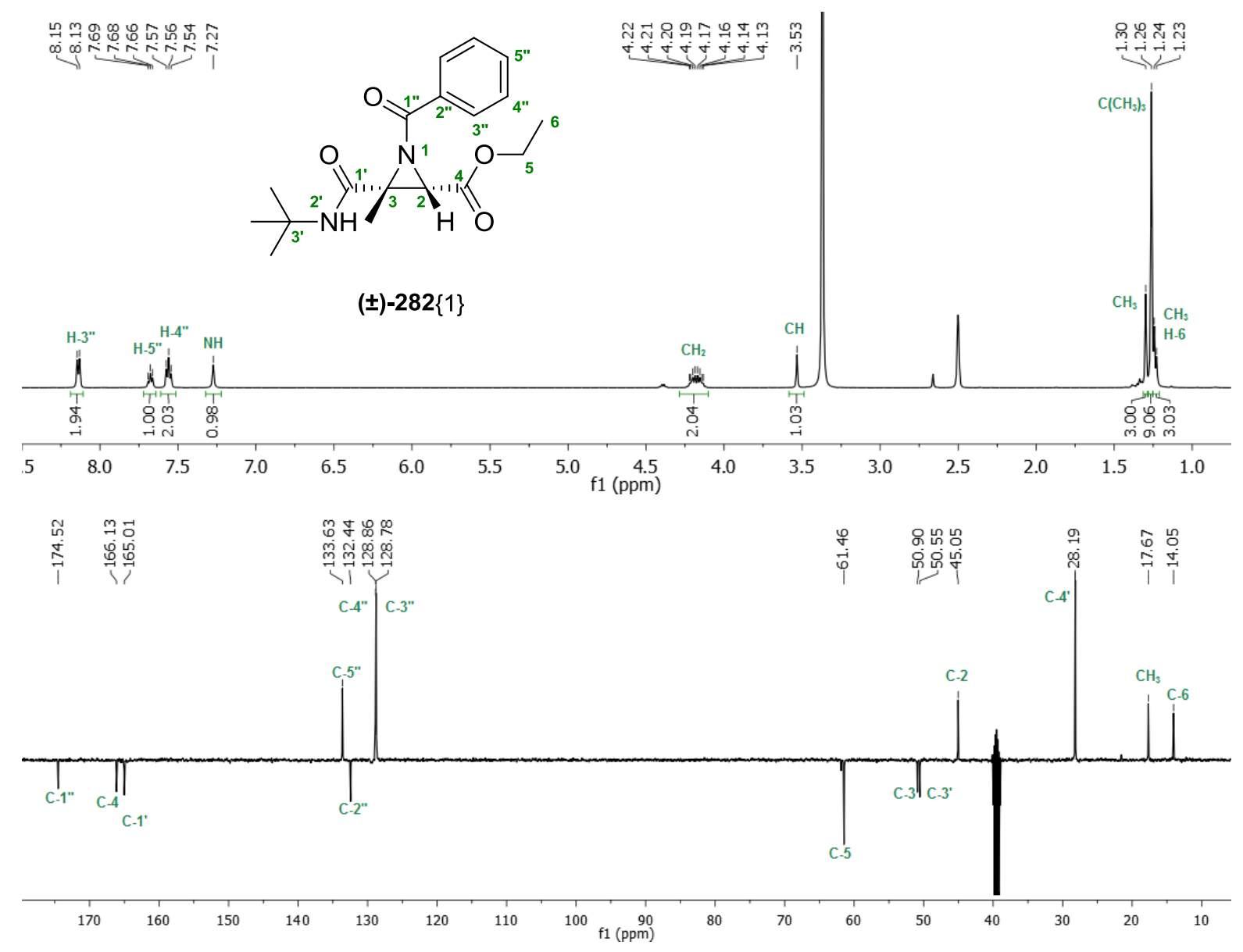

49. ábra. A ( \pm )-282 $\{1\}$ vegyület ${ }^{1} \mathrm{H}$ - és ${ }^{13} \mathrm{C}-\mathrm{NMR}$ spektrumai (DMSO- $d_{6}$ )

A diasztereomerek sztereokémiáját NOESY NMR-technikával határoztuk meg (50. ábra). A ( \pm )-281-\{1\} vegyületnél a C-3 metilcsoport protonjai és a C-2-hez tartozó észtercsoport metilén-protonjai intenzív keresztcsúcsot mutattak, a C-3 metilcsoport és a C-2 proton közötti korreláció viszont nagyságrendekkel kisebb volt, ami transz térállásra utal. Másrészről a $( \pm)-282-$ $\{1\}$ vegyületnél a C-3 metilcsoport protonjai és a C-2 hidrogén között a cisz-viszonynak megfelelő intenzív keresztcsúcsot figyeltünk meg. A keresztcsúcsok térfogati integrálja alapján a magtávolságok kvantitatív meghatározására is sor került, amely alátámasztotta az előbbi észrevételeket (a számítások alapja, hogy a keresztcsúcsok intenzitása a csatoló hidrogénatomok távolságának függvényében, $\mathrm{r}^{-6}$ hatványnak megfelelően változik).

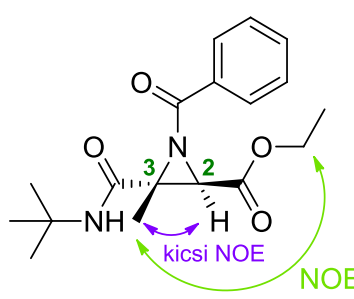

(士)-281\{1\}

transz

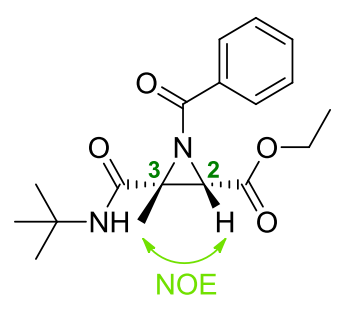

(士)-282 $\{1\}$

50. ábra. A ( \pm -281 $\{1\}$ és $( \pm)-282-\{1\}$ vegyületek térszerkezetét (transz/cisz) meghatározó korrelációk 
Ezt követően az oldószer, hőmérséklet és koncentráció modellreakcióra gyakorolt hatását vizsgáltuk (2. táblázat). A reakciókat HPLC-vel követve megállapítottuk, hogy az oldószer minősége a diasztereomer arányt nem befolyásolja. A kifejlesztett Ugi-Joullié-3CR leginkább az apoláris (toluol és 1,4-dioxán), illetve DMF kivételével a poláris aprotikus oldószereket $\left(\mathrm{CHCl}_{3}\right.$, THF és $\mathrm{MeCN}$ ) részesíti előnyben (2. táblázat, 3-8. kísérlet), protikus oldószereket (EtOH és IPA) alkalmazva a termékek alacsony hozammal képződtek (2. táblázat, 1. és 2. kísérlet). A tesztelt oldószerek közül a THF bizonyult a leghatékonyabb közegnek, mellyel 72\%-os kombinált HPLC hozamot értünk el. Ezenfelül mikrohullámú besugárzást alkalmazva kísérletet tettünk a reakcióidő csökkentésére, azonban a reakció hömérsékletét növelve $\left(80-120^{\circ} \mathrm{C}\right)$ hozam és diasztereoszelektivitás csökkenést tapasztaltunk (2. táblázat, 9-11. kísérlet). Az oldószer mennyiségének növelése a kombinált hozam és a diasztereomer arány tekintetében viszont előnyösnek bizonyult (2. táblázat, 13. és 14. kísérlet).

2. táblázat. Az Ugi-Joullié-3CR körülményeinek optimalizálása

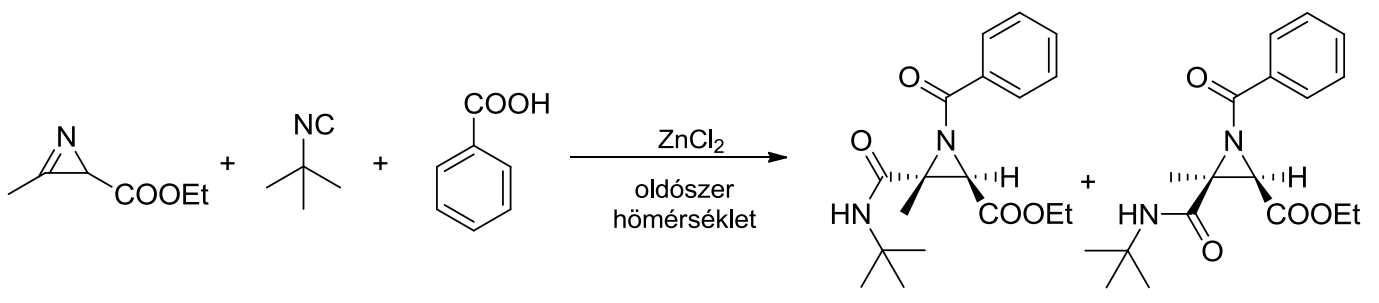

(士)-270a

$279 a$

$280 a$

$( \pm)-281\{1\}$

$( \pm)-282\{1\}$

\begin{tabular}{llllll}
\hline Kísérlet & Oldószer & Oldószer mennyisége $(\mathbf{m l})$ & Hömérséklet $\left.^{(} \mathbf{C}\right)$ & Hozam $\left._{(\%)}\right)^{\boldsymbol{a}}$ & $\mathbf{d r}^{\boldsymbol{a}}$ \\
\hline 1 & EtOH & 0,5 & 55 & 12 & $91: 9$ \\
2 & IPA & 0,5 & 55 & 40 & $93: 7$ \\
3 & MeCN & 0,5 & 55 & 56 & $89: 11$ \\
4 & DMF & 0,5 & 55 & 0 & - \\
5 & THF & 0,5 & 55 & 72 & $93: 7$ \\
6 & CHCl $_{3}$ & 0,5 & 55 & 61 & $90: 10$ \\
7 & 1,4-Dioxán & 0,5 & 55 & 64 & $92: 8$ \\
8 & Toluol & 0,5 & 55 & 57 & $91: 9$ \\
9 & THF & 0,5 & $80^{b}$ & 64 & $94: 6$ \\
10 & THF & 0,5 & $100^{b}$ & 58 & $91: 9$ \\
11 & THF & 0,5 & $120^{b}$ & 55 & $88: 12$ \\
12 & THF & 0,25 & 55 & 68 & $91: 9$ \\
13 & THF & 1 & 55 & 77 & $94: 6$ \\
$\mathbf{1 4}$ & THF & $\mathbf{2}$ & $\mathbf{5 5}$ & $\mathbf{8 1}$ & $\mathbf{9 6 : 4}$ \\
\hline
\end{tabular}

Reakciókörülmények: $2 H$-azirin ( $0,25 \mathrm{mmol})$, terc-butil-izocianid (1,1 ekv.), benzoesav (1,1 ekv.), vízmentes oldószer ( $0,5 \mathrm{ml})$, vízmentes $\mathrm{ZnCl}_{2}$ (25 mol\%), argon, 3 óra.

${ }^{[a]}$ A diasztereomerek összhozamát és a dr-t HPLC-vel határoztuk meg. ${ }^{[b]}$ MW körülmény: 30 perc, $250 \mathrm{~W}$. ${ }^{[c]} 4$ óra reakcióidő volt szükséges a teljes konverzióhoz. 
A reakciókörülmények beállítását követően különböző karbonsavak alkalmazhatóságát kívántuk vizsgálni, a racém etil-3-metil-2H-azirin-2-karboxilát (( \pm$)$-270a) és terc-butil-izocianid (279a) komponensek felhasználása mellett (3. táblázat, 1-10. kísérlet). A képződő diasztereomereket oszlopkromatográfiás eljárással választottuk el, arányukat pedig minden esetben a nyers reakcióelegy LC-MS spektroszkópiai vizsgálatával határoztuk meg. Emellett minden reakcióelegyet kvantitatív ${ }^{1} \mathrm{H}-\mathrm{NMR}$ analízisnek vetettünk alá, hogy a maximálisan elérhető hozam meghatározásával a reakció, valamint az alkalmazott tisztítási eljárás hatékonyságát jellemezzük. Elsőként elektronküldő (3-MeO, 4-HO) és elektronszívó (2-Cl) szubsztituenseket tartalmazó benzoesavakat teszteltünk, melyek 56-72\%-os izolált hozammal szolgáltatták a kívánt $( \pm)-\mathbf{2 8 1}\{2-4\}$ termékeket. Fenil-ecetsav és 3,4,5-trimetoxi-fahéjsav felhasználásával szintén jó hozamokat értünk el (( \pm )-281\{5\}: 69\% és ( \pm )-281\{6\}: 60\%). Amellett, hogy az eljárás heteroaromás nikotinsavval (280g) egyaránt kompatibilis $(( \pm)-\mathbf{2 8 1}\{7\}$ : 28\%), a reakció alifás karbonsavakra, úgymint ecetsavra (280h) és klórecetsavra (280i) is kiterjeszthető, közepes-jó hozamú termékképződést lehetővé téve $(( \pm)-281\{8\}: 75 \%$ és $( \pm)$ 281\{9\}: 55\%). Ezenfelül meglepődve tapasztaltuk, hogy a gyenge nukleofil karakterü trifluorecetsav 54\%-os izolált hozammal eredményezte a céltermék ( \pm -)-281 $\{10\} N$-acilaziridint, mely tovább igazolja a módszer széleskörü alkalmazhatóságát.

Az egyedényes eljárás hatékonyságát a továbbiakban különböző alifás és aromás izocianidokkal (279b-f) teszteltük, azirin komponensként a $( \pm)-270 a$ analógot, karbonsav komponensként benzoesavat választva (3. táblázat, 11-15. kísérlet). Az alifás terc-oktil- és ciklohexil-izocianid esetében a reakciók a várt módon magas hozammal mentek végbe (78 és 71\%), míg benzil- és aromás izocianidokkal alacsonyabb termeléseket (38-60\%) értünk el. Érdekes módon az elektronszívó nitrocsoportot tartalmazó 279f fenil-izocianid jobb izolált hozamot (( \pm$)$-281 \{15\}: 60\%) eredményezett, mint a nukleofilabb karakterü 3,4,5-trimetoxifenilizocianid $(( \pm)-\mathbf{2 8 1}\{14\}: 38 \%)$.

A módszer általánosságát vizsgálva az izocianid és karbonsav komponensek egyéb kombinációival további analógokat szintetizáltunk (3. táblázat, 16-28. kísérlet). A kifejlesztett eljárás funkciós csoportok szélés skálájának alkalmazása mellett a céltermék $( \pm)$-281 $N$ acilaziridineket 22-80\%-os hozammal, magas diasztereoszelektivitással (93:7 - >99:1 transz: cisz dr) szolgáltatta. A reakciók hatékonyságát főként az izocianid reagens elektronikai sajátsága határozta meg. Benzil- és alifás izocianidokkal jobb izolált hozamokat értünk el (58-80\%; 3. táblázat, 16-23. kísérlet), mint aromás származékokkal (22-56\%; 3. táblázat, 24-28. kísérlet). 
3. táblázat. Karbonsavak és izocianidok tesztelése a kifejlesztett háromkomponensü $N$-acilaziridin-2karboxamid szintézisben

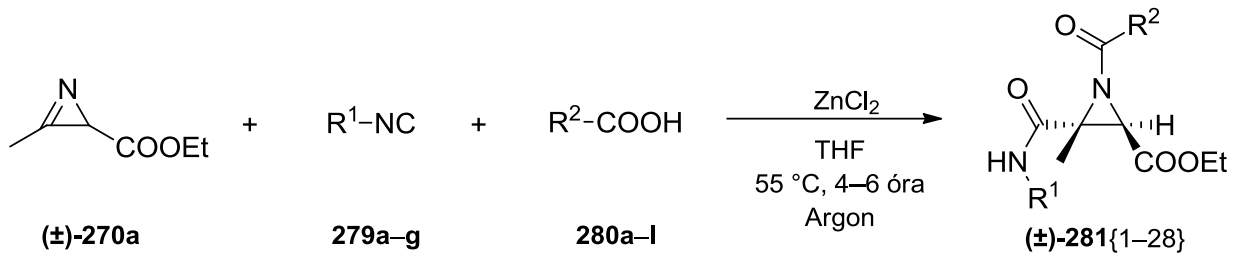

\begin{tabular}{|c|c|c|c|c|c|c|c|}
\hline Kísérlet & 279 & $\mathbf{R}^{1}$ & 280 & $\mathbf{R}^{2}$ & Termék & $\operatorname{Hozam}(\%)^{a}$ & $d \mathbf{r}^{b}$ \\
\hline 1 & 279a & $t$-Bu & 280a & $\mathrm{Ph}$ & $281\{1\}$ & $69(78)$ & $96: 4$ \\
\hline 2 & 279a & $t$-Bu & $280 b$ & $3-\mathrm{MeO}-\mathrm{C}_{6} \mathrm{H}_{4}$ & $\mathbf{2 8 1}\{2\}$ & $72(79)$ & $95: 5$ \\
\hline 3 & 279a & $t-\mathrm{Bu}$ & $280 \mathrm{c}$ & $4-\mathrm{HO}-\mathrm{C}_{6} \mathrm{H}_{4}$ & $\mathbf{2 8 1}\{3\}$ & $56(62)$ & $93: 7$ \\
\hline 4 & 279a & $t-\mathrm{Bu}$ & 280d & $2-\mathrm{Cl}-\mathrm{C}_{6} \mathrm{H}_{4}$ & $\mathbf{2 8 1}\{4\}$ & $61(74)$ & $94: 6$ \\
\hline 5 & 279a & $t$-Bu & $280 \mathrm{e}$ & $\mathrm{Bn}$ & $281\{5\}$ & $69(75)$ & $94: 6$ \\
\hline 6 & 279a & $t-\mathrm{Bu}$ & $280 f$ & 3,4,5-tri-MeO- $\mathrm{C}_{6} \mathrm{H}_{2} \mathrm{CHCH}$ & $281\{6\}$ & $60(69)$ & $95: 5$ \\
\hline 7 & 279a & $t-\mathrm{Bu}$ & $280 \mathrm{~g}$ & 3-piridil & $\mathbf{2 8 1}\{7\}$ & $28(38)$ & $>99$ \\
\hline 8 & 279a & $t-\mathrm{Bu}$ & $280 h$ & $\mathrm{Me}$ & $\mathbf{2 8 1}\{8\}$ & $75(79)$ & $95: 5$ \\
\hline 9 & 279a & $t-\mathrm{Bu}$ & $280 \mathrm{i}$ & $\mathrm{ClCH}_{2}$ & $281\{9\}$ & $55(60)$ & $94: 6$ \\
\hline 10 & 279a & $t$-Bu & $280 j$ & $\mathrm{CF}_{3}$ & $281\{10\}$ & $54(58)$ & $97: 3$ \\
\hline 11 & $279 b$ & $t$-Oktil & 280a & $\mathrm{Ph}$ & $281\{11\}$ & $78(82)$ & $94: 6$ \\
\hline 12 & 279c & $c$-Hex & 280a & $\mathrm{Ph}$ & $281\{12\}$ & $71(75)$ & $93: 7$ \\
\hline 13 & 279d & $\mathrm{Bn}$ & 280a & $\mathrm{Ph}$ & $281\{13\}$ & $58(60)$ & $94: 6$ \\
\hline 14 & $279 e$ & 3,4,5-tri- $\mathrm{MeO}-\mathrm{C}_{6} \mathrm{H}_{2}$ & 280a & $\mathrm{Ph}$ & $281\{14\}$ & $38(40)$ & $97: 3$ \\
\hline 15 & $279 f$ & $4-\mathrm{NO}_{2}-\mathrm{C}_{6} \mathrm{H}_{4}$ & 280a & $\mathrm{Ph}$ & $281\{15\}$ & $60(69)$ & $97: 3$ \\
\hline 16 & 279b & $t$-Oktil & $280 \mathrm{e}$ & $\mathrm{Bn}$ & $281\{16\}$ & $77(80)$ & $95: 5$ \\
\hline 17 & $279 \mathrm{~g}$ & $n$-Pentil & $280 \mathrm{e}$ & $\mathrm{Bn}$ & $281\{17\}$ & $79(82)$ & $95: 5$ \\
\hline 18 & 279c & $c$-Hex & $280 b$ & $\mathrm{Me}$ & $281\{18\}$ & $68(76)$ & $96: 4$ \\
\hline 19 & 279c & $c$-Hex & $280 \mathrm{e}$ & $\mathrm{Bn}$ & $281\{19\}$ & $60(71)$ & $93: 7$ \\
\hline 20 & 279c & $c$-Hex & $280 \mathrm{k}$ & 2,4,6-tri-Me- $\mathrm{C}_{6} \mathrm{H}_{2}$ & $\mathbf{2 8 1}\{20\}$ & $80(85)$ & $96: 4$ \\
\hline 21 & 279c & $c$-Hex & 2801 & $3-\mathrm{F}-\mathrm{C}_{6} \mathrm{H}_{4}$ & $\mathbf{2 8 1}\{21\}$ & $77(86)$ & $93: 7$ \\
\hline 22 & 279d & $\mathrm{Bn}$ & $280 \mathrm{e}$ & $\mathrm{Bn}$ & $281\{22\}$ & $67(69)$ & $93: 7$ \\
\hline 23 & 279d & $\mathrm{Bn}$ & $280 f$ & $3-\mathrm{MeO}-\mathrm{C}_{6} \mathrm{H}_{4}$ & $281\{23\}$ & $58(60)$ & $96: 4$ \\
\hline 24 & 279e & 3,4,5-tri-MeO- ${ }_{6} \mathrm{H}_{2}$ & $280 b$ & $\mathrm{Me}$ & $281\{24\}$ & $22(34)$ & $99: 1$ \\
\hline 25 & 279e & 3,4,5-tri-MeO- $\mathrm{C}_{6} \mathrm{H}_{2}$ & $280 \mathrm{e}$ & $\mathrm{Bn}$ & $281\{25\}$ & $36(40)$ & $97: 3$ \\
\hline 26 & 279e & 3,4,5-tri-MeO- ${ }_{6} \mathrm{H}_{2}$ & 280a & $4-\mathrm{CF}_{3}-\mathrm{C}_{6} \mathrm{H}_{4}$ & $281\{26\}$ & $29(36)$ & $97: 3$ \\
\hline 27 & $279 f$ & $4-\mathrm{NO}_{2}-\mathrm{C}_{6} \mathrm{H}_{4}$ & $280 c$ & $\mathrm{ClCH}_{2}$ & $281\{27\}$ & $56(62)$ & $96: 4$ \\
\hline 28 & $279 f$ & $4-\mathrm{NO}_{2}-\mathrm{C}_{6} \mathrm{H}_{4}$ & 2801 & $3-\mathrm{F}-\mathrm{C}_{6} \mathrm{H}_{4}$ & $\mathbf{2 8 1}\{28\}$ & $28(38)$ & $96: 4$ \\
\hline
\end{tabular}

Reakciókörülmények: $2 H$-azirin (0,5 mmol), izocianid (1,1 ekv.), karbonsav (1,1 ekv.), vízmentes THF (4 ml), vízmentes $\mathrm{ZnCl}_{2}$ (25 mol\%), argon, $55^{\circ} \mathrm{C}$, 4 óra.

[a] Transz izomer izolált hozama (zárójelben NMR-hozam). Az NMR hozam meghatározása ${ }^{1} \mathrm{H}-\mathrm{NMR}$ méréssel, 1,3,5trimetoxibenzol belső standard segítségével történt. ${ }^{[b]}$ Transz:cisz diasztereomer arány (nyers reakcióelegyből LC-MS-sel meghatározva). 
Az N-acilaziridin-2-karboxamid vegyületkönyvtár-szintézis következő fázisában az UgiJouillé-3CR kiterjeszthetőségét vizsgáltuk más $2 H$-azirinekre, az összehasonlíthatóság érdekében egyebek mellett terc-butil-izocianid (279a) és benzoesav (280a) komponenseket felhasználva (4. táblázat). A terc-butoxikarbonil-csoporttal szubsztituált $( \pm)$-270b azirin a $( \pm)$ 270a etoxikarbonil-analóghoz viszonyítva hasonló diasztereomer aránnyal, azonban alacsonyabb hozammal eredményezte a megfelelő ( \pm )-281\{29-32\} N-acilaziridineket (4. táblázat, 1-4. kísérlet). A teljesen szubsztituált $( \pm)$-270c azirin esetében viszont a transz diasztereomer képződésének jelentős csökkenését (60:40-63:37 transz:cisz dr) és a reakcióidő növekedését (6 óra) figyeltük meg, amely valószínüleg az addícionálódó izocianid és az azirin $\mathrm{R}^{3}$ szubsztituense (metil) között fellépő sztérikus repulziónak köszönhető (4. táblázat, 5-7. kísérlet). A terc-butilés benzil-izocianidból képződő termékeket diasztereomer keverékként, 55\% és 41\%-os kombinált izolált hozammal, a $( \pm)-\mathbf{2 8 1}\{34\}$ aziridint tiszta diasztereomerként állítottuk elő (31\%). Nagyobb térkitöltésű $\mathrm{R}^{3}=$ benzil szubsztituens bevezetésével a diasztereomer arány tovább csökkent; a $( \pm)$-270d azirin a reakció szterokémiai kimenetelét megfordítva a $( \pm)$ 282\{36\} cisz-aziridint szolgáltatta fötermékként (42:58 transz:cisz dr; 4. táblázat, 8. kísérlet). Végül megállapítottuk, hogy a kifejlesztett Ugi-Joullié-3CR aromás $2 H$-azirinekkel egyaránt kompatibilis. A $( \pm)$-270e és $( \pm)$-270f 2-fenilazirinekből kiindulva közepes-jó hozammal (2870\%), kiváló diasztereoszelektivitás mellett (> 99:1 dr) állítottunk elő további transz- $N$ acilaziridin-2-karboxamid származékokat (( \pm -281\{37-44\}; 4. táblázat, 9-16. kísérlet). 
4. táblázat. $2 H$-azirinek tesztelése a kifejlesztett háromkomponensű $N$-acilaziridin-2-karboxamid szintézisben

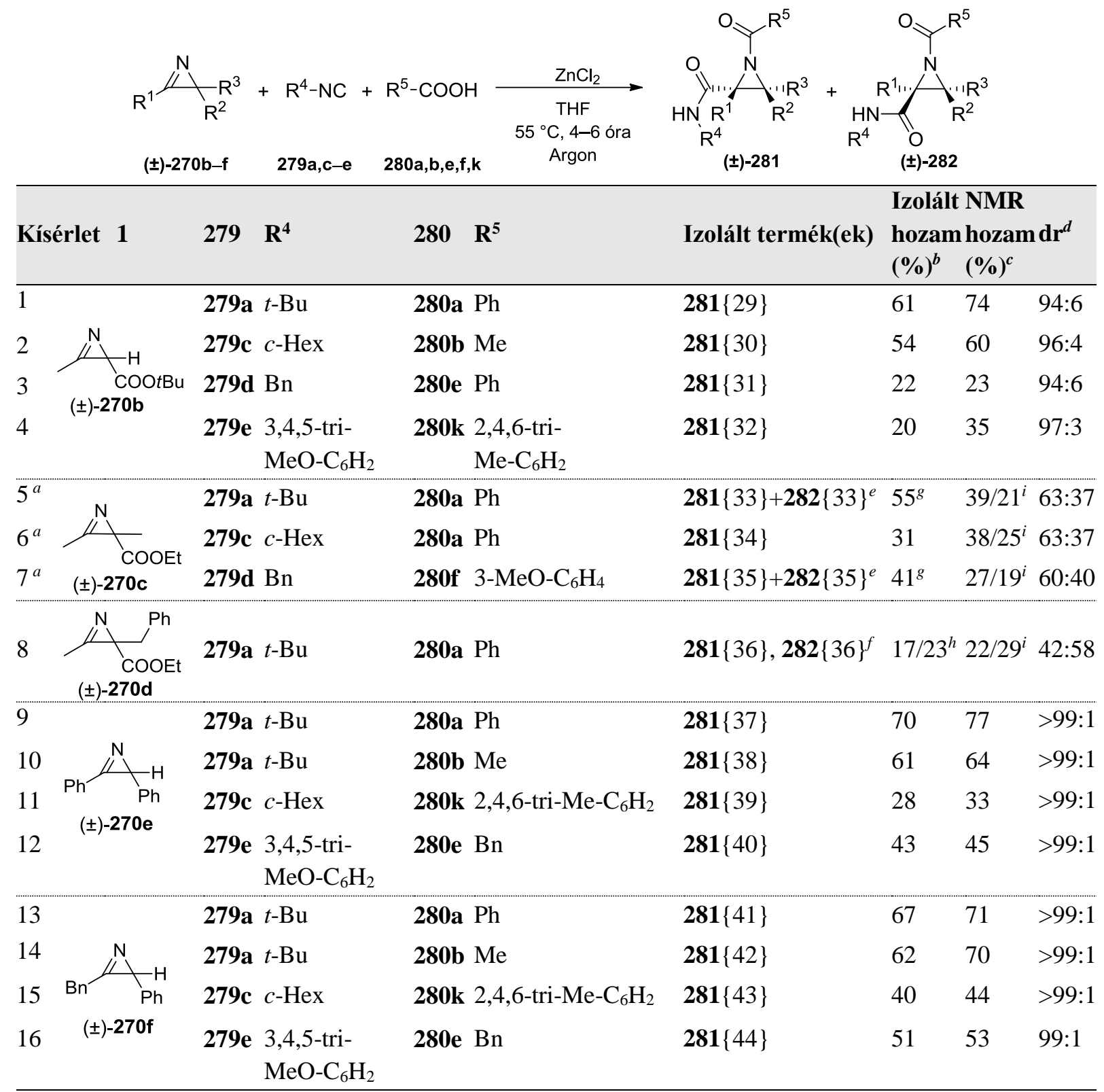

Reakciókörülmények: $2 H$-azirin ( $0,5 \mathrm{mmol})$, izocianid (1,1 ekv.), karbonsav (1,1 ekv.), vízmentes THF (4 ml), vízmentes $\mathrm{ZnCl}_{2}$ ( $25 \mathrm{~mol} \%$ ), argon, $55^{\circ} \mathrm{C}, 4$ óra.

[a] 6 óra reakcióidő szükséges. ${ }^{[b]}$ Transz izomer izolált hozama. ${ }^{[c]}$ Az NMR hozam meghatározása ${ }^{1} \mathrm{H}-\mathrm{NMR}$ méréssel, 1,3,5trimetoxibenzol belső standard segítségével történt. ${ }^{[\mathrm{d}]}$ Transz:cisz diasztereomer arány (nyers reakcióelegyből LC-MS-sel meghatározva). ${ }^{[\mathrm{e}]}$ Diasztereomer keverék. ${ }^{[\mathrm{fl}]}$ Külön izolált diasztereomerek. ${ }^{[\mathrm{g}]}$ Kombinált izolált hozam. ${ }^{[\mathrm{h}]}$ Külön izolált transz és cisz diasztereomer hozamok. ${ }^{[i]}$ Transz:cisz diasztereomerek.

Karbonsav komponensként $N$-védett aminosavakat alkalmazva néhány példán keresztül megmutattuk, hogy a kifejlesztett Ugi-Joullié-3CR aziridin peptidomimetikumok szintézisére is alkalmazható (5. táblázat). A 280m-p $N$-védett L-glutaminsav, L-glutamin, $\beta$-alanin és Dfenilglicin származékokat az optimalizált körülmények között $( \pm)$-270a azirinnel és terc-butilizocianiddal (279a) reagáltatva a kívánt 281\{45-48\} peptideket 64-82\%-os izolált hozammal, magas diasztereoszelektivitással (transz:cisz dr) kaptuk. Az optikailag aktív aminosav 
komponensek figyelemre méltó aszimmetrikus indukciót nem okoztak. Az enantiomertiszta királis aminosavakból fötermékként képződő transz diasztereomerek oszlopkromatográfiás elválasztása sikertelennek bizonyult, így a $\mathbf{2 8 1}\{45\}, \mathbf{2 8 1}\{46\}$ és $\mathbf{2 8 1}\{48\}$ termékeket diasztereomer-keverékként izoláltuk.

5. táblázat. $N$-védett aminosavak tesztelése a kifejlesztett háromkomponensủ $N$-acilaziridin-2-karboxamid szintézisben

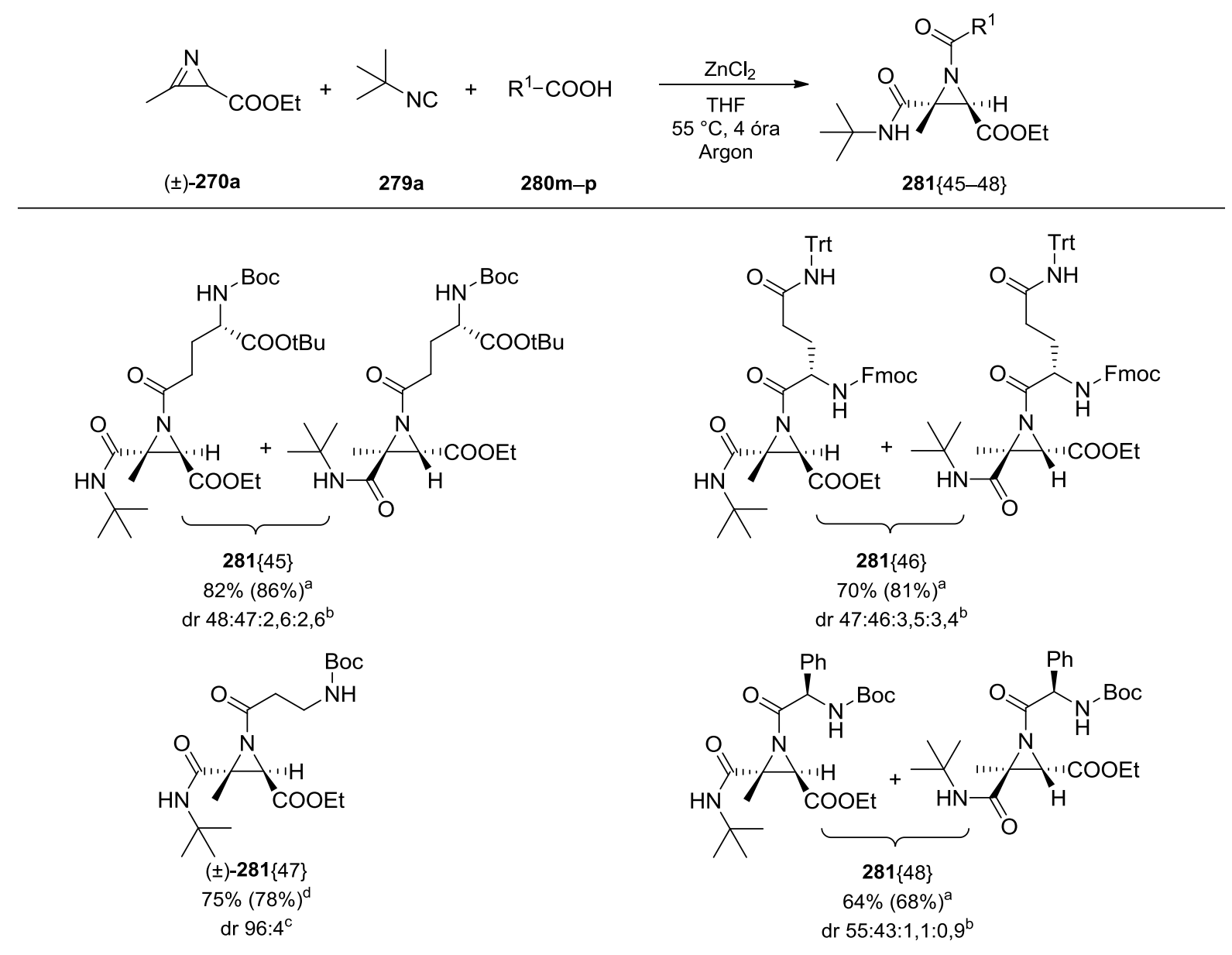

Reakciókörülmények: $2 H$-azirin $(0,5 \mathrm{mmol})$, izocianid (1,1 ekv.), aminosav (1,1 ekv.), vízmentes THF (4 ml), vízmentes $\mathrm{ZnCl}_{2}$ (25 mol\%), argon, $55^{\circ} \mathrm{C}, 4$ óra.

${ }^{[a]}$ A két transz diasztereomer összesített hozama (zárójelben NMR hozam). Az NMR hozam meghatározása ${ }^{1} \mathrm{H}-\mathrm{NMR}$ méréssel, 1,3,5-trimetoxibenzol belső standard segítségével történt. ${ }^{[\mathrm{b}]}$ Diasztereomer arány (transz:transz:cisz:cisz), LC-MS-sel nyers reakcióelegyből meghatározva. ${ }^{[\mathrm{c}]}$ Diasztereomer arány (transz:cisz). ${ }^{[\mathrm{d}]}$ Transz diasztereomer izolált hozama (zárójelben NMR hozam).

A reakciót optikailag aktív (-)-(R)-270a $2 H$-azirinnel is elvégeztük (51. ábra). Epimerizációt nem tapasztaltunk, oszlopkromatográfiás tisztítást követően a $(+)-(2 R, 3 R)-\mathbf{2 8 1}\{1\}$ célvegyületet a kiindulási $2 H$-azirinével megegyező enantiomer felesleggel (72\% ee), 68\%-os hozammal állítottuk elő. Érdemes megjegyezni, hogy dietil-éterből történő további átkristályosítással jelentős enantiomerdúsulás érhető el (92\% ee). 


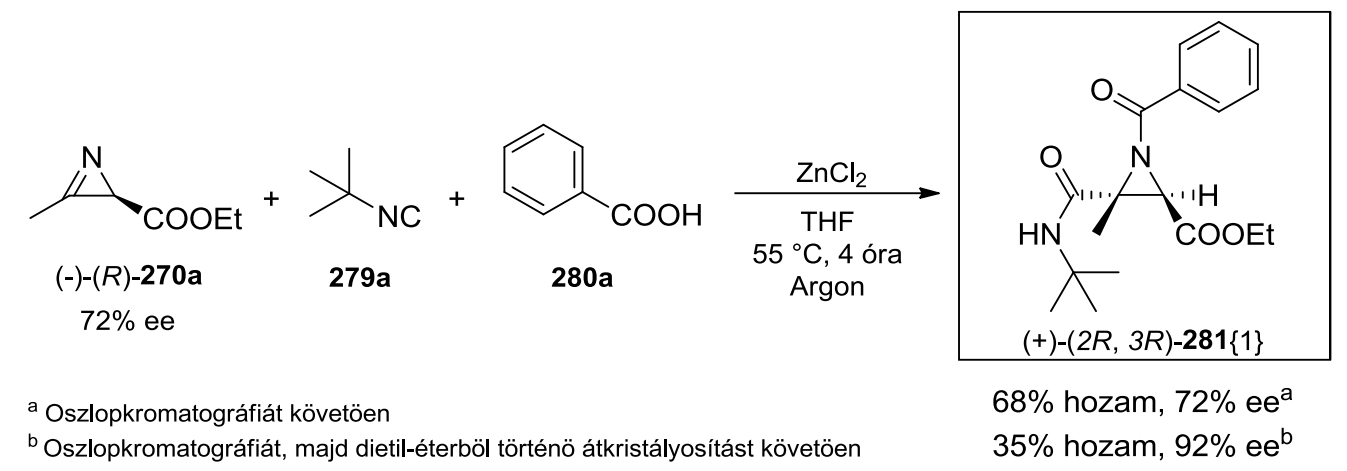

51. ábra. Ugi-Joullié-3CR optikailag aktív $2 H$-azirinnel

A kifejlesztett Ugi-Joullié reakcióval előállított $( \pm)$-281 és $( \pm)$-282 végtermékek szerkezetét ${ }^{1} \mathrm{H}$ - és ${ }^{13} \mathrm{C}-\mathrm{NMR}$, valamint tömegspektrometriai mérésekkel igazoltuk. $\mathrm{A}( \pm)-\mathbf{2 8 1}\{1\}$, $( \pm)-282\{1\},( \pm)-281\{34\},( \pm)-281\{36\},( \pm)-282\{36\},( \pm)-281\{37\}$ és $( \pm)-281\{41\}$ molekulák szerkezetét emellett HSQC, HMBC és NOESY kétdimenziós NMR technikák alkalmazásával is alátámasztottuk.

A továbbiakban az előállított $N$-acilaziridinek felhasználhatóságát mutattuk be néhány származékképzésen keresztül. Először az etoxikarbonil funkciós csoport savamiddá történő átalakíthatóságát vizsgáltuk. A $( \pm)-\mathbf{2 8 1}\{1\},( \pm)-281\{11\}$ és $( \pm)-\mathbf{2 8 1}\{12\}$ aziridin-észterek alkalikus hidrolízisét követően - a ( \pm )-283-285 karbonsav sók izolálása nélkül - a megfelelő aminnal peptidkémiai kapcsolószerek (EDC/HOBt) jelenlétében amidálást hajtottunk végre (6. táblázat). Az elektronhiányos aziridin gyürü a hidrolízis és a kapcsolási reakció körülményeinek ellenállt, így a kívánt ( \pm )-287-292 $N$-acilaziridin-2,3-dikarboxamid származékokat oszlopkromatográfiás tisztítást követően 71-95\%-os izolált hozammal állítottuk elő.

6. táblázat. Savamid funkció kialakítása

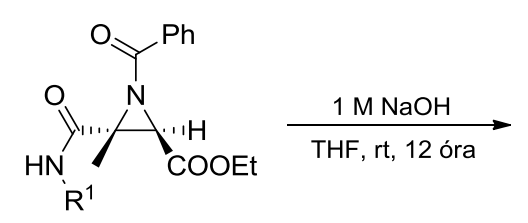

$( \pm)-\mathbf{2 8 1}\{1,11,12\}$

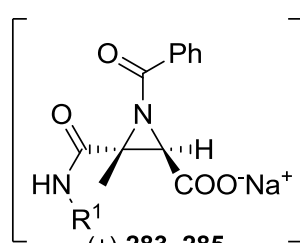

$( \pm)-283-285$

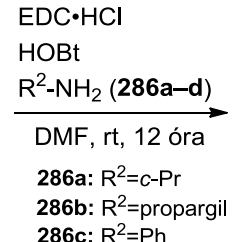

286c: $R^{2}=P h$

286d: $R^{2}=c-B u$

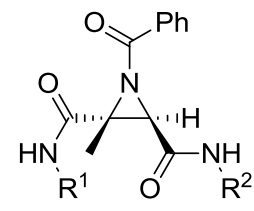

$( \pm)-287-292$

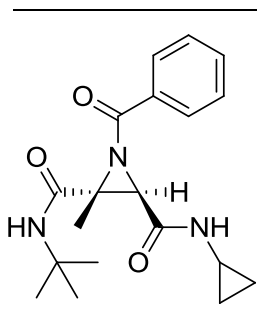

$( \pm)-287$

$74 \%$

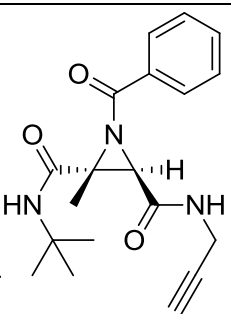

(士)-288

$85 \%$

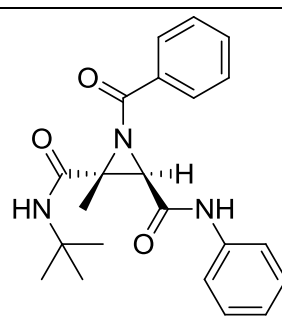

$( \pm)-289$ $95 \%$

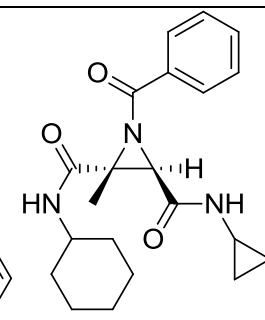

(士)-290 $92 \%$

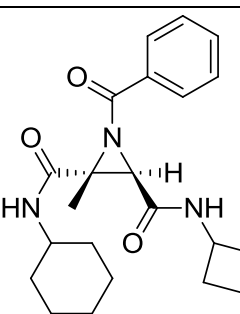

(士)-291

$71 \%$

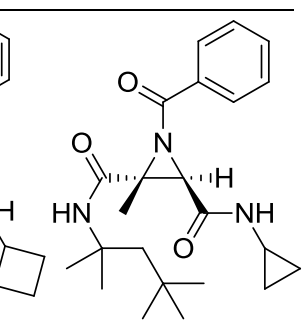

(士)-292 $87 \%$

Reakciókörülmények a hidrolízishez: $( \pm)$-281 aziridin $(0,3 \mathrm{mmol}), \mathrm{THF}(1,5 \mathrm{ml}), \mathrm{NaOH}(1,16$ ekv.; $1 \mathrm{M}$-os vizes oldat), rt, 12 óra. Reakciókörülmények a kapcsoláshoz: DMF (6 ml), EDC·HCl (1,16 ekv.), 286 (1,0ekv.), HOBt (1,38 ekv.), rt, 12 óra. 
$N$-szubsztituálatlan aziridinek előállíthatóságát tanulmányozva a ( \pm )-281 $\{10\}$ analóg $N$-trifluor-acetil-csoportját az aziridinek szakirodalmában ismeretlen módon nátriumbórhidriddel, enyhe reakciókörülmények között eltávolítottuk, a ( \pm )-293 célvegyületet két óra reakcióidő után 92\%-os hozammal izoláltuk (52. ábra).

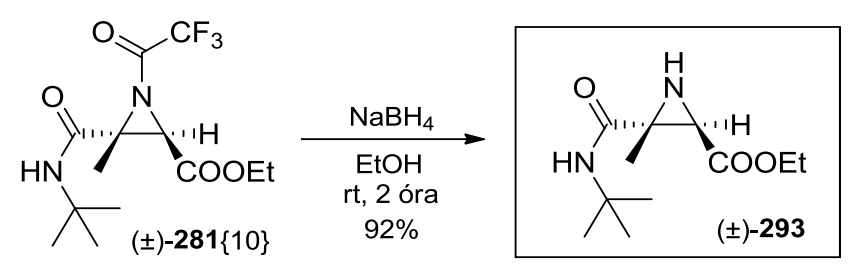

52. ábra. $N$-szubsztituálatlan aziridin származék képzése

Végül az Ugi-Joullié-3CR termékek gyürübővítési (oxazolinná történő izomerizáció) és gyürünyitási reakcióit vizsgáltuk. Mivel az $N$-acilaziridin-2-karboxamidok funkcionálisan $\alpha / \beta$ aminosavaknak tekinthetők, így az értékes $\alpha$-hidroxi- $\beta$ - vagy $\beta$-hidroxi- $\alpha$-aminosavak előállítását célozva a gyürünyitást vízzel, Lewis-sav katalízissel kívántuk megvalósítani.

Elsőként a ( \pm -281 $\{1\}$ és $( \pm)-\mathbf{2 8 2}\{1\}$ diasztereomerekből kiindulva Heine-reakcióval (NaI, DMF, $100{ }^{\circ} \mathrm{C}, 12$ óra) regioszelektíven, a konfiguráció retenciójával a transz- $( \pm)-294$ és cisz-( \pm -295 oxazolinokat alakítottuk ki (53. ábra, A módszer, 78\% és 80\%-os izolált hozam). Váratlan módon $\mathrm{BF}_{3} \cdot 2 \mathrm{H}_{2} \mathrm{O}$ alkalmazásával diklórmetánban a gyürü felnyílása helyett szintúgy oxazolinok képződését tapasztaltuk, azonban a reakció teljes regioszelektivitással és a konfiguráció retenciójával az előző termékek regioizomeréhez, a transz-( \pm )-296 és cisz-( \pm -297 oxazolinok keletkezéséhez vezetett (53. ábra, B módszer, 85\% és 72\%-os izolált hozam). Ily módon a megfelelő reakciókörülmény kiválasztásával befolyásolni tudtuk, hogy a nukleofil támadás az aziridin gyürü kevésbé szubsztituált C-2 (A módszer) vagy térgátoltabb C-3 szénatomján (B módszer) valósuljon meg, szelektíven a kívánt regioizomert eredményezve. Emellett érdemes kiemelni, hogy egyik oxazolin képzés során sem tapasztaltunk epimerizációt. 


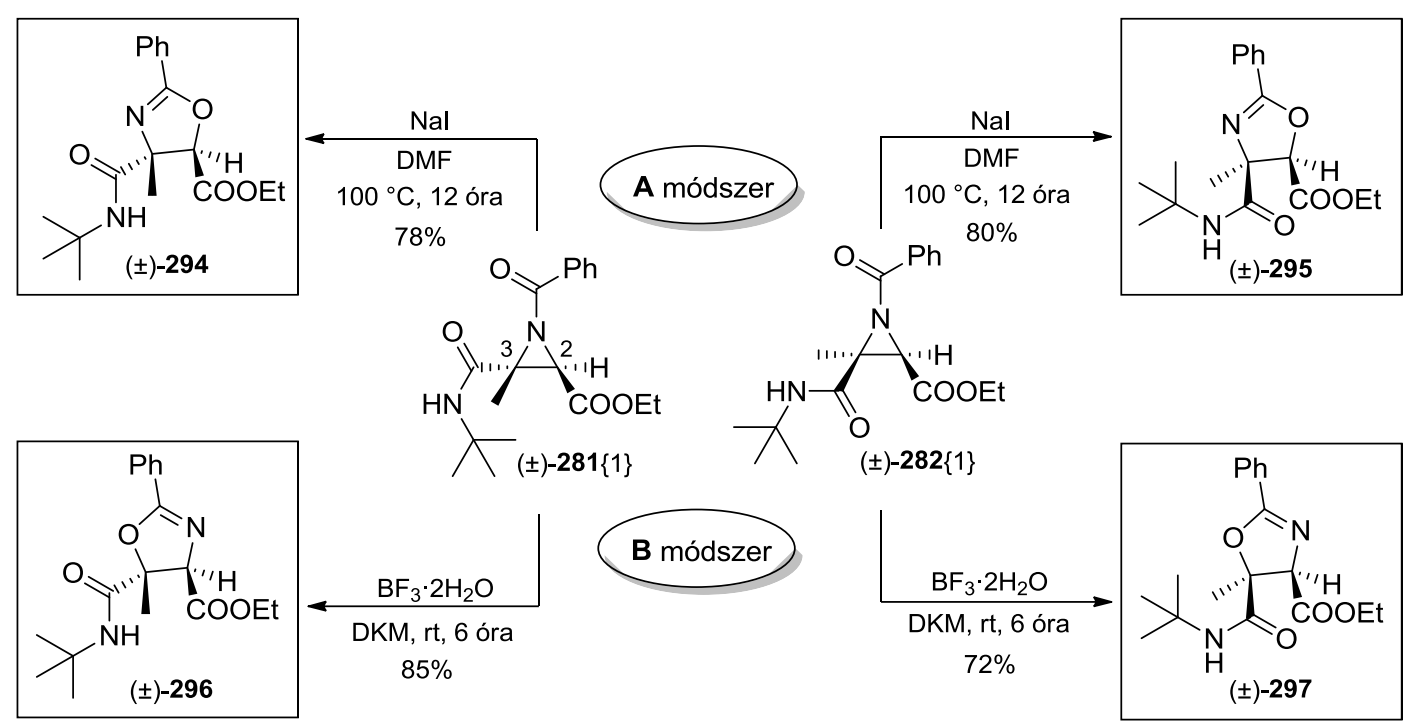

53. ábra. $( \pm)$-281 $\{1\}$ és $( \pm)-\mathbf{2 8 2}\{1\} N$-acilaziridin diasztereomerek regioszelektív izomerizációja oxazolinná

A ( \pm )-294-297 termékek szerkezetét egy- és kétdimenziós NMR-spektroszkópiai módszerek segítségével igazoltuk, melyet a ( \pm -294 és $( \pm)$-296 oxazolinok példáján keresztül mutatok be. A $( \pm)$-294 és $( \pm)$-296 vegyületek ${ }^{1}$ H- és ${ }^{13}$ C-NMR spektrumain HSQC, HMBC és NOESY NMR módszerek segítségével teljes jelhozzárendelést végeztünk (54. és 55. ábra). A ( \pm )-294 vegyület esetén az aziridin gyürü metil- $(1,35 \mathrm{ppm})$ és az etoxikarbonil- $\mathrm{CH}_{2}$-csoportja (4,20 ppm) között megjelenő NOESY keresztcsúcs alapján, míg a $( \pm)$-296 analóg esetén az aziridin gyürü hidrogénatomja (5,05 ppm) és a terc-butilcsoport (1,25 ppm) között fellépő NOE kölcsönhatás alapján mindkét vegyületnél a kiindulási $( \pm)-\mathbf{2 8 1}\{1\}$ aziridinnel megegyező konfigurációjú transz térállást igazoltunk. Ennek alapján az azonos moláris tömegü két termék ${ }^{1} \mathrm{H}$ - és ${ }^{13} \mathrm{C}$-NMR spektrumaiban lévő kémiai eltolódás különbségeket kizárólag regioizomériára vezettük vissza. Az oxazolin gyürü C-4 és C-5 szénatomjainak kémiai eltolódásait (54. és 55. ábra, piros kerettel jelölve a ${ }^{13} \mathrm{C}-\mathrm{NMR}$ spektrumokon) a kiindulási $( \pm)$-281 $\{1\}$ vegyület megfelelő C-2 és C-3 szénatomjainak kémiai eltolódásaival összehasonlítva megfigyeltük, hogy míg a ( \pm )-294 oxazolin esetében a szekunder szénatom kémiai eltolódása változik nagyobb mértékben (C-5: 42,9 $\rightarrow 81,0$ ppm, ellenben C-4: 49,8 $\rightarrow$ 77,8 ppm), addig a ( \pm )-296 regioizomer esetén a tercier szénatom jelénél tapasztalható nagyobb kémiai eltolódás-változás (C-5: $49,8 \rightarrow 87,0$ ppm, ellenben C-4: 42,9 $\rightarrow 73,6 \mathrm{ppm})$. Feltételezve, hogy a nagyobb elektronegativitású oxigénatom nagyobb kémiai eltolódásváltozást okoz a hozzá közvetlenül kapcsolódó szénatom jelében, mint a nitrogénatom, a fenti észrevételek alapján a regioizomerek között egyértelmü különbséget tudtunk tenni. A heteroatomok induktív effektusa - azonos korrelációt mutatva - az oxazolin gyürü hidrogénatomjára és metilcsoportjára is hatással volt (piros kerettel jelölve a ${ }^{1} \mathrm{H}-\mathrm{NMR}$ spektrumokon), alátámasztva a szerkezetigazolást. 


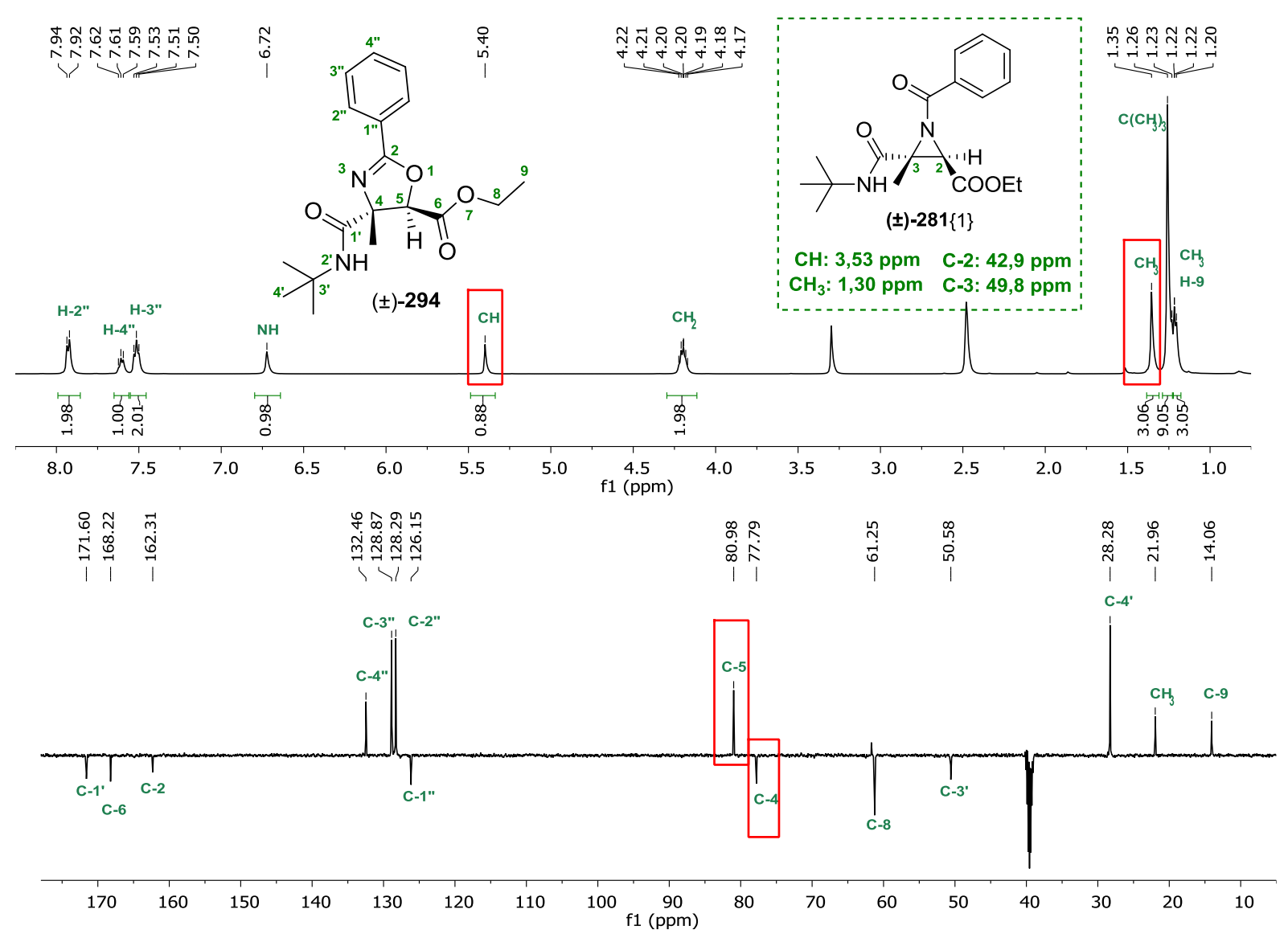

54. ábra. A ( \pm )-294 vegyület ${ }^{1} \mathrm{H}$ - és ${ }^{13} \mathrm{C}-\mathrm{NMR}$ spektrumai (DMSO- $d_{6}$ )

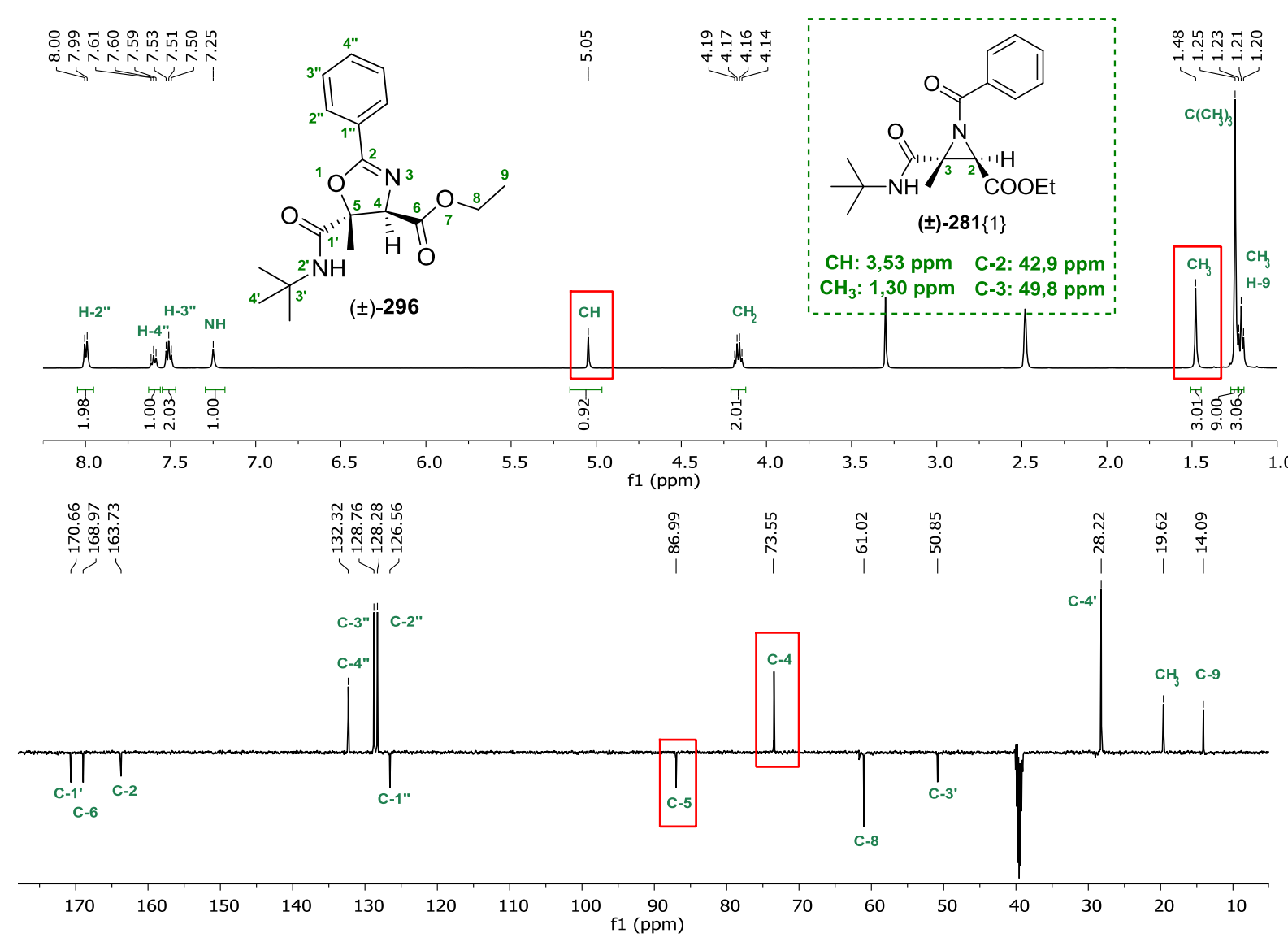

55. ábra. A ( \pm )-296 vegyület ${ }^{1} \mathrm{H}$ - és ${ }^{13} \mathrm{C}-\mathrm{NMR}$ spektrumai (DMSO- $d_{6}$ ) 
Az Ugi-Joullié $N$-acilaziridin termékek gyürünyitási reakcióját tanulmányozva a $( \pm)$ $\mathbf{2 8 1}\{1\}$ vegyületet acetonitril oldószerben, különböző Lewis- és Brønsted-savak jelenlétében (25 mol\% $\mathrm{InCl}_{3}, \mathrm{AlCl}_{3}, \mathrm{Sc}(\mathrm{OTf})_{3}, \mathrm{Yb}(\mathrm{OTf})_{3}, p$ - TsOH, $\mathrm{HClO}_{4}$ és TFA) vízzel (10 ekvivalens) reagáltattuk. A tesztelt katalizátorok közül a $\mathrm{Sc}(\mathrm{OTf})_{3}$ kimagasló aktivitást mutatott, a reakciókörülmények további optimalizálása nélkül teljes regioszelektivitással, 72\%-os izolált hozammal eredményezte a $( \pm)$-298 $\beta$-hidroxi- $\alpha$-aminosav származékot (56. ábra). A nyers reakcióelegy LC-MS és NMR vizsgálata alapján egységes termék képződését tapasztaltuk, azonban NMR módszerrel nem sikerült meghatároznunk, hogy melyik diasztereomer képződött. Mivel a gyürüfelnyílás elektronhiányos tercier szénatomon (C-3) történik Lewis-sav katalízis mellett, így a C-3-konfiguráció inverziója ( $\mathrm{S}_{\mathrm{N}} 2$ mechanizmus, $\left.( \pm)-\mathbf{2 9 8 a}\right)$ és retenciója (Lewissav által közvetített $\mathrm{S}_{\mathrm{N}} 1$-mechanizmus, $\left.( \pm)-298 b\right)^{195}$ egyaránt feltételezhető.
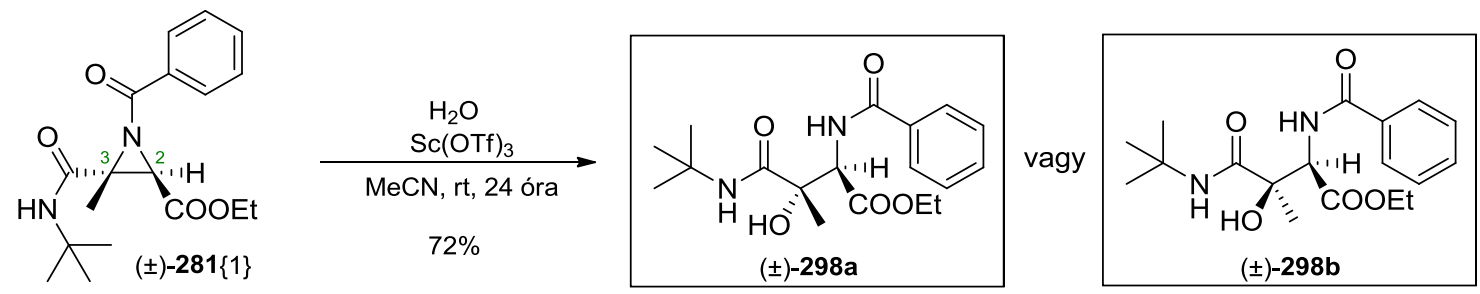

56. ábra. ( \pm -281 $\{1\} N$-acilaziridin gyürünyitása vízzel

A termék szerkezetének meghatározásához az egydimenziós ${ }^{1} \mathrm{H}$ - és ${ }^{13} \mathrm{C}-\mathrm{NMR}$ spektrumokon túl HSQC és HMBC kétdimenziós NMR módszereket is alkalmaztunk, melyek segítségével teljes jelhozzárendelést végeztünk (57. ábra). Először a HSQC és HMBC spektrumok alapján azonosítottuk az $\mathrm{OH}$ és $\mathrm{NH}$ csoportok szignálját, majd a ${ }^{1} \mathrm{H}-\mathrm{NMR}$ spektrumban egymással csatoló NH (7,93 ppm, d, $J=9,5 \mathrm{~Hz}$, kékkel jelölve) és CH (5,00 ppm, d, $J=9,4 \mathrm{~Hz}$, pirossal jelölve) protonok dublett jelei alapján megállapítottuk, hogy a ( \pm )-281 $\{1\}$ aziridin gyürüje a N-1 és C-3 kötés mentén hasadt el.

Az Avidin Kft. biológus munkatársai az előállított $( \pm)-281\{1-48\}$ és $( \pm)-287-292 N$ acilaziridin származékokat in vitro citotoxicitási vizsgálatoknak vetették alá A549 humán tüdőkarcinóma, MCF7 humán emlőkarcinóma, HL60 humán leukémia és 3T3 egér fibroblaszt sejtvonalakon. A vegyületek többsége a tesztelt koncentrációtartományban $(1-30 \mu \mathrm{M})$ inaktívnak bizonyult vagy csekély citotoxikus hatást mutatott $\left(\mathrm{IC}_{50}>20 \mu \mathrm{M}\right)$. 


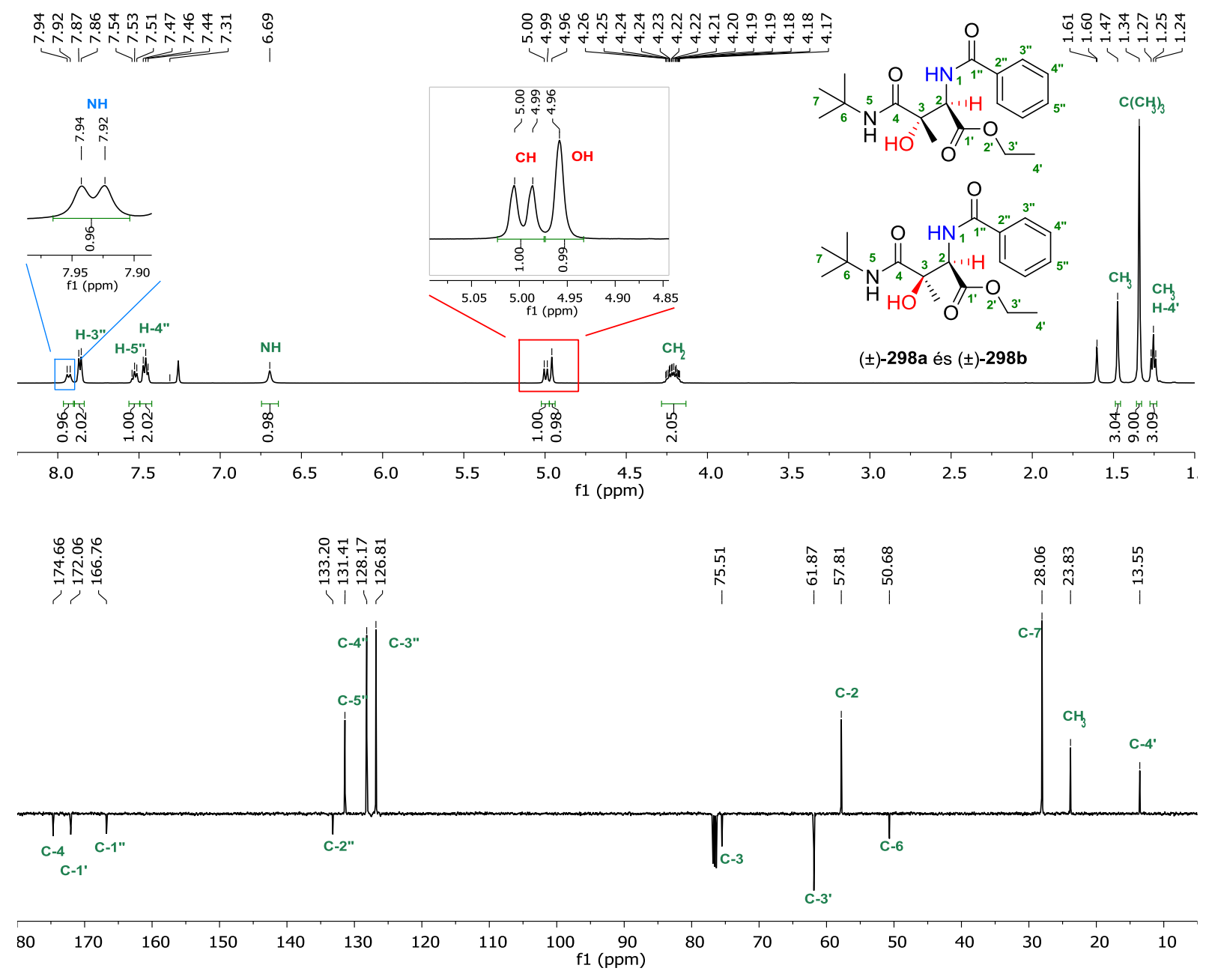

57. ábra. A ( $( \pm)-298 a /( \pm)-298 b$ vegyület ${ }^{1} \mathrm{H}$ - és ${ }^{13} \mathrm{C}-\mathrm{NMR}$ spektrumai $\left(\mathrm{CDCl}_{3}\right)$

\subsection{1,3-diazaspiro[biciklo[3.1.0]hexán]oxindol vegyületek szintézise $\mathrm{e}^{196}$}

A 2H-azirinek és in situ képzett oxindol-alapú azometin-ilidek 1,3-dipoláris cikloaddíciójának kidolgozására irányuló kísérleti munkánk kezdetén az izatin (299a), D-(-)-2fenilglicin (300a) és $( \pm)$-etil-3-metil-2H-azirin-2-karboxilát $(( \pm)-\mathbf{2 7 0 a})$ háromkomponensü reakcióját tanulmányoztuk. Az első kísérleteket poláris közegben, szobahőmérsékleten végeztük (7. táblázat, 1-5. kísérlet). A reakció DMSO oldószerben 54\%-os kombinált HPLC hozammal, magas diasztereoszelektivitással $(92: 8$ dr) a $( \pm)$-301a és $( \pm)$-301b endo cikloadduktokhoz vezetett (7. táblázat, 5. kísérlet). A reakciókörülményeket tovább optimalizálva vízmentes oldószerek szélesebb skáláját teszteltük $60{ }^{\circ} \mathrm{C}$-on (7. táblázat, 6-16. kísérlet). A kívánt cikloadduktok képződésének többnyire a protikus és poláris aprotikus oldószerek kedveztek (7. táblázat, 6-8, 11 és 16 kísérlet), míg apoláris közegben alacsony HPLC hozamokat tapasztaltunk (7. táblázat, 12-14 kísérlet). A kombinált hozamokat tekintve az etanol és a DMSO bizonyult a 
leghatékonyabb oldószernek (7. táblázat, 7. és 16. kísérlet, 71 és 73\%-os HPLC-hozamok), azonban DMSO-ban magasabb diasztereoszelektivitást (92:8 dr) értünk el. A koncentráció változtatása hasonló vagy alacsonyabb hozamokat eredményezett, a diasztereomer arányra pedig nem volt hatással (1. táblázat, 17-21. kísérlet). Végül az optimalizált reakciókörülményeket alkalmazva (DMSO, 0,25 M ( \pm -270a, $\left.60^{\circ} \mathrm{C}\right)$ a $( \pm)$-301a főtermékeket 8 óra reakcióidőt követően teljes konverzió és kiváló diasztereroszelektivitás (92:8 dr) mellett 65\%-os hozammal izoláltuk (7. táblázat, 19. kísérlet). (A $( \pm)$-301b cikloadduktot egy méretnövelt szintézis során (5 mmol izatin) 3\%-os hozammal állítottuk elő.)

7. táblázat. A reakció körülményeinek optimalizálása

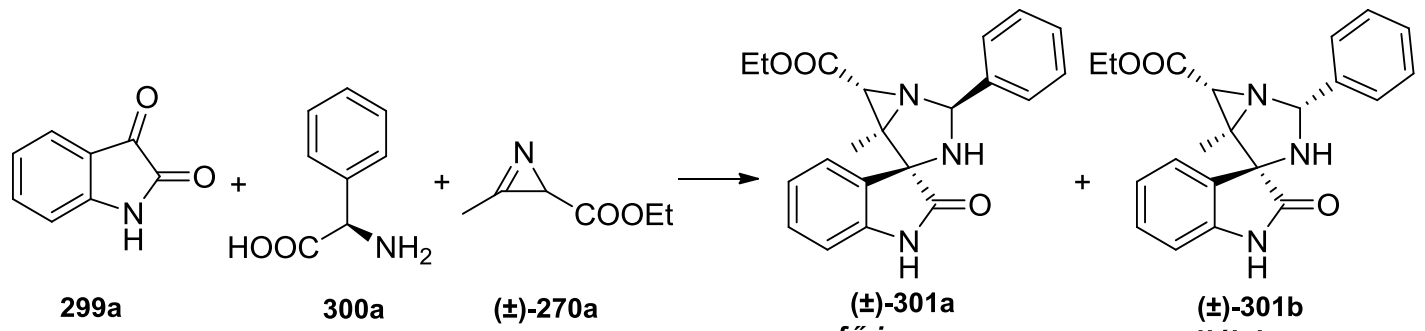

\begin{tabular}{|c|c|c|c|c|c|c|c|}
\hline Kísérlet & Oldószer & $\begin{array}{l}\text { Oldószer } \\
\text { (ml) }\end{array}$ & $\begin{array}{l}\text { Höm. } \\
\left({ }^{\circ} \mathrm{C}\right)\end{array}$ & Idő (óra) & $\begin{array}{l}\text { Konverzióa }^{a} \\
\text { (\%) }\end{array}$ & $\operatorname{Hozam}(\%)^{b}$ & $d r^{c}$ \\
\hline 1 & $\mathrm{MeOH}$ & 1 & $\mathrm{rt}$ & 36 & 91 & 44 & $87: 13$ \\
\hline 2 & $\mathrm{EtOH}$ & 1 & $\mathrm{rt}$ & 36 & 81 & 9 & $85: 15$ \\
\hline 3 & TFE & 1 & $\mathrm{rt}$ & 36 & 83 & 10 & $62: 38$ \\
\hline 4 & DMF & 1 & $\mathrm{rt}$ & 36 & 84 & 11 & $90: 10$ \\
\hline 5 & DMSO & 1 & $\mathrm{rt}$ & 36 & 93 & $54(47)^{d}$ & $92: 8$ \\
\hline 6 & $\mathrm{MeOH}$ & 1 & 60 & 36 & 98 & 53 & $84: 16$ \\
\hline 7 & EtOH & 1 & 60 & 36 & 98 & 71 & $82: 18$ \\
\hline 8 & IPA & 1 & 60 & 36 & 90 & 49 & $74: 26$ \\
\hline 9 & $t-\mathrm{BuOH}$ & 1 & 60 & 36 & 85 & 13 & $59: 41$ \\
\hline 10 & $\mathrm{MeCN}$ & 1 & 60 & 36 & 84 & 4 & $74: 26$ \\
\hline 11 & DMF & 1 & 60 & 36 & 97 & 37 & $90: 10$ \\
\hline 12 & THF & 1 & 60 & 36 & 83 & 2 & $52: 48$ \\
\hline 13 & toluol & 1 & 60 & 36 & - & - & - \\
\hline 14 & $\mathrm{CHCl}_{3}$ & 1 & 60 & 36 & 82 & 2 & $52: 48$ \\
\hline 15 & TFE & 1 & 60 & 36 & 94 & 31 & $53: 47$ \\
\hline 16 & DMSO & 1 & 60 & 36 & 100 & 73 & $92: 8$ \\
\hline 17 & DMSO & 0,25 & 60 & 8 & 100 & 51 & $92: 8$ \\
\hline 18 & DMSO & 0,5 & 60 & 8 & 100 & 61 & $92: 8$ \\
\hline 19 & DMSO & 1 & 60 & 8 & 100 & $72(65)^{d}$ & 92:8 \\
\hline 20 & DMSO & 2 & 60 & 8 & 100 & 68 & $92: 8$ \\
\hline 21 & DMSO & 4 & 60 & 8 & 100 & 69 & $92: 8$ \\
\hline
\end{tabular}

Reakciókörülmények: izatin (0,25 mmol), D-(-)-2-fenilglicin (0,3 mmol), 2H-azirin (0,25 mmol), vízmentes oldószer, argon. ${ }^{[a]}$ 299a konverziója ${ }^{[b]}( \pm)$-301a és $( \pm)$-301b izomerek összesített hozama, melyet HPLC-vel határoztunk meg. ${ }^{[c]}$ A diasztereomer arányt (dr) HPLC-vel határoztuk meg $\left(( \pm)\right.$-301a és $( \pm)$-301b kalibrációjával). ${ }^{[\mathrm{d}]}$ Zárójelben a $( \pm)$-301a izolált hozama $(0,5 \mathrm{mmol}$ izatin, 0,6 mmol D-(-)-2-fenilglicin, 0,5 mmol $2 \mathrm{H}$-azirin, $2 \mathrm{ml}$ vízmentes $\mathrm{DMSO}$, argon, $60^{\circ} \mathrm{C}, 8$ óra). 
A ( \pm -301a és $( \pm)$-302b cikloadduktok szerkezetét egy- $\left({ }^{1} \mathrm{H}\right.$ - és $\left.{ }^{13} \mathrm{C}-\mathrm{NMR}\right)$ és kétdimenziós (HSQC, HMBC, COSY és NOESY) NMR spektroszkópiai módszerekkel igazoltuk. A négy kiralitáscentrummal rendelkező diasztereomerek konfigurációjának meghatározásában a NOESY kísérletek segítettek (a legfontosabb csatolások a 58. ábrán nyilakkal jelölve). Emellett a fö izomer (( \pm -301a) NMR módszerekkel igazolt szerkezetét egy röntgenkrisztallográfiás felvétel is alátámasztotta (58. ábra).

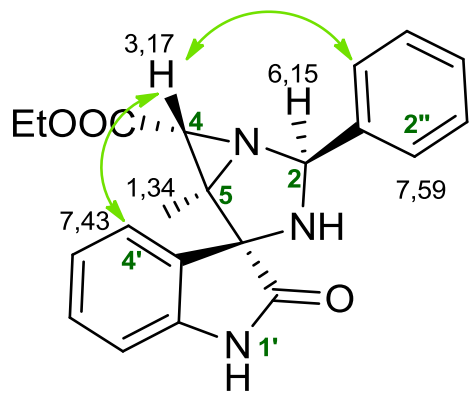

(士)-301a

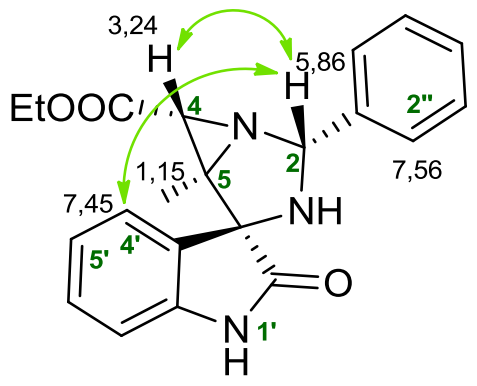

$( \pm)-301 b$

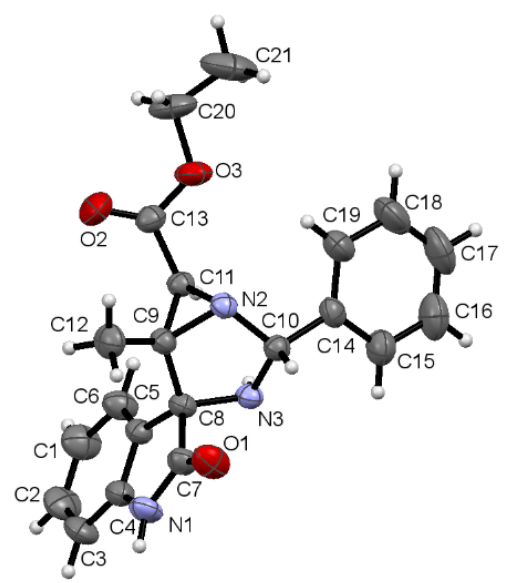

58. ábra. A ( \pm$)$-301a és $( \pm)$-301b diasztereomerek térszerkezetét meghatározó NOE csatolások és a $( \pm)$-301a termék kristályszerkezete

Az optimalizált reakciókörülmények mellett a modellreakció izatin, majd $2 H$-azirin komponensének szisztematikus változtatásával egy 15 tagból álló vegyületkönyvtárat hoztunk létre (8. táblázat). Elektronban gazdag és elektronban szegény izatinok a reakcióban egyaránt részt vettek, lehetővé téve a ( \pm -302a- $( \pm)-307 a$ spirooxindolok közepes-jó diasztereoszelektivitású (72:28-91:9 dr), 44-78\% izolált hozamú előállítását (8. táblázat, „i” rész). Figyelemre méltó szubsztituenshatást nem tapasztaltunk, azonban $N$-benzilizatin, illetve elektronszívó csoportokkal $\left(\mathrm{Br}\right.$ és $\left.\mathrm{NO}_{2}\right)$ 7-szubsztituált izatinok alkalmazása alacsonyabb hozamokat eredményezett $(( \pm)-307 a: 55 \%,( \pm)$-303a: 44\% és $( \pm)-304 a: 50 \%)$. A kifejlesztett szintézismódszer aromás $2 H$-azirinekre egyaránt kiterjeszthető (8. táblázat, „ii” rész). 2,3difenilazirinek alkalmazásakor - a benzolgyürü szubsztituenseinek elektronikus tulajdonságától függetlenül - a megfelelö ( $( \pm)$-308a-311a termékeket jó hozammal (65-78\%) és diaszteroszelektivitással nyertük. Érdekes módon a C-3 pozícióban benzilcsoportot tartalmazó $( \pm)$-270f $2 H$-azirinnel jelentős diasztereoszelektivitás-csökkenést tapasztaltunk $(( \pm)-\mathbf{3 1 2 a}, 63: 37$ dr). A mellék diasztereomer nagyobb arányú képződését a benzilcsoport és az azometin-ilid fenilcsoportja között fellépő $\pi-\pi$ kölcsönhatás magyarázhatja. Az $\mathrm{R}^{4}$ szubsztituens sztérikus tulajdonsága ezzel szemben elhanyagolhatónak bizonyult az 1,3-DC sztereokémiai kimenetelére $(( \pm)$-313a: $92: 8$ dr és $( \pm)-314 a: 87: 13$ dr). 
8. táblázat. Izatinok és $2 H$-azirinek tesztelése az 1,3-diazaspiro[biciklo[3.1.0]hexán]oxindol-szintézisben<smiles>[R]C1=NC1[R16](=O)[O-]</smiles>

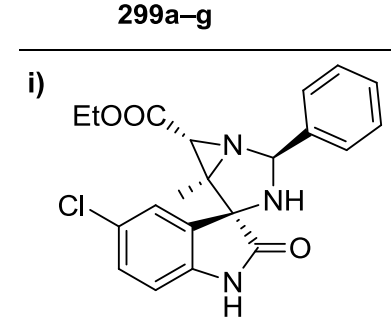

(士)-302a, $78 \%$ 91:9 dr<smiles>CCOC1(C)[C@@H](C)[C@@]12NC(=O)Nc1c(Br)cccc12</smiles>

(士)-303a, 44\% $87: 13 \mathrm{dr}$<smiles>CCOC[C@H]1[C@@H]2c3cccc([N+](=O)[O-])c3NC(=O)[C@]12NC(c1ccccc1)c1ccccc1</smiles>

(士)-304a, 50\% $81: 19 \mathrm{dr}$<smiles>CCOC(=O)[C@H]1[C@@H]2N1C(c1ccccc1)NC21C(=O)Nc2cc(OC)ccc21</smiles>

(士)-305a, 63\% $72: 28 \mathrm{dr}$<smiles></smiles>

(士)-306a, 70\% $87: 13 \mathrm{dr}$<smiles>CCOC[C@H]1N2C(c3ccccc3)C3(C(=O)N(Cc4ccccc4)c4ccccc43)C12COCC</smiles>

(士)-307a, 55\% $82: 18 \mathrm{dr}$<smiles>O=C1Nc2ccccc2C12CN(C(c1ccccc1)c1ccc(Cl)cc1)C(c1ccccc1)N2</smiles>

$( \pm)-310 a, 67 \%$ $88: 12 \mathrm{dr}$<smiles>O=C1Nc2ccccc2C1(Cc1ccccc1)N1CCCC1c1ccccc1</smiles>

$( \pm)-311 \mathrm{a}, 78 \%$ 90:10 dr<smiles>O=C1Nc2ccccc2[C@]12NC(c1ccccc1)C2c1ccccc1</smiles>

(士)-308a, 65\% $80: 20 \mathrm{dr}$<smiles>COc1ccc(C2(c3ccccc3)CC3(NC(=O)N3)C(c3ccccc3)N2)cc1</smiles>

(士)-309a, 71\% $87: 13 \mathrm{dr}$<smiles>CC(C)(C)OC(=O)[C@@H]1N2C(c3ccccc3)NC1(C(=O)Nc1ccccc1)[C@@H]2c1ccccc1</smiles>

(士)-312a, 32\% 63:37 dr

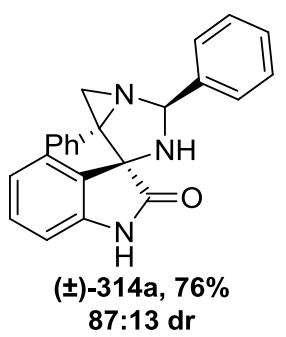<smiles>COc1ccc2c(c1)CC1(C2)NC(c2ccccc2)N2CC(c3ccccc3)NC21</smiles>

(士)-315a, 68\% $80: 20 \mathrm{dr}$

(士)-313a, 66\%

92:8 dr

Reakciókörülmények: izatin (0,5 mmol), D-(-)-2-fenilglicin (0,6 mmol), $2 H$-azirin (0,5 mmol), 2 ml vízmentes DMSO, argon, $60{ }^{\circ} \mathrm{C}, 8$ óra. A diasztereomer arányt (dr) a nyers reakcióelegyből vett minta LC-MS mérésével határoztuk meg.

$\mathrm{Az}$ egyedényes eljárás hatékonyságát a továbbiakban különbözö $\alpha$-aminosavakkal teszteltük; az optimalizált reakciókörülményeket követve izatin (299a) és ( \pm )-etil-3-metil-2Hazirin-2-karboxilát $(( \pm)-270 a)$ komponensek felhasználásával további 12 tagból álló molekulakönyvtárat szintetizáltunk (9. táblázat). Para helyzetben elektronküldő (Me) és elektronvonzó ( $\mathrm{Cl}, \mathrm{F})$ csoportokkal szubsztituált fenilglicinek alkalmazásakor jelentős 
szubsztituenshatást nem tapasztaltunk, a várt ( \pm -317a-319a spirooxindolokat jó izolált hozammal (68-81\%) és diasztereomer aránnyal (82:18-90:10) kaptuk. Az R ${ }^{1}$ oldallánc egy vagy két metiléncsoporttal történő meghosszabbítása szignifikáns hatást nem gyakorolt az 1,3-DC hatékonyságára (( \pm -320a-322a: 61-69\%, 81:19-87:13 dr). Trifunkciós $\alpha$-aminosavak, mint például az $S$-benzil-cisztein, triptofán, szerin és a glutamin, a kifejlesztett eljárással szintén kompatibilisnek bizonyultak (( \pm )-323a-326a: 37-66\%, 76:24-84:16 dr). Alifás aminosavak alkalmazhatóságát szemléltetve a reakciót norleucinnal is elvégeztük, a várt $( \pm)-327 a$ cikloadduktot 70\%-os izolált hozammal nyertük. Ezzel szemben meglepődve tapasztaltuk, hogy az aliciklusos L-prolinnal a megfelelő $( \pm)$-328a termék csak 11\%-os izolált hozammal állítható elö.

9. táblázat. Aminosavak tesztelése az 1,3-diazaspiro[biciklo[3.1.0]hexán]oxindol-szintézisben<smiles>O=C1Nc2ccccc2C1=O</smiles>

299a<smiles>[R]C1NCCCC[R]1C(=O)O</smiles>

$300 a-m$<smiles>CCOC(=O)C1N=C1C</smiles>

(士)-270a<smiles>[R]C1N2CC([Z7])C3(C(=O)Nc4ccccc43)N12</smiles>

(士)-317a-328a

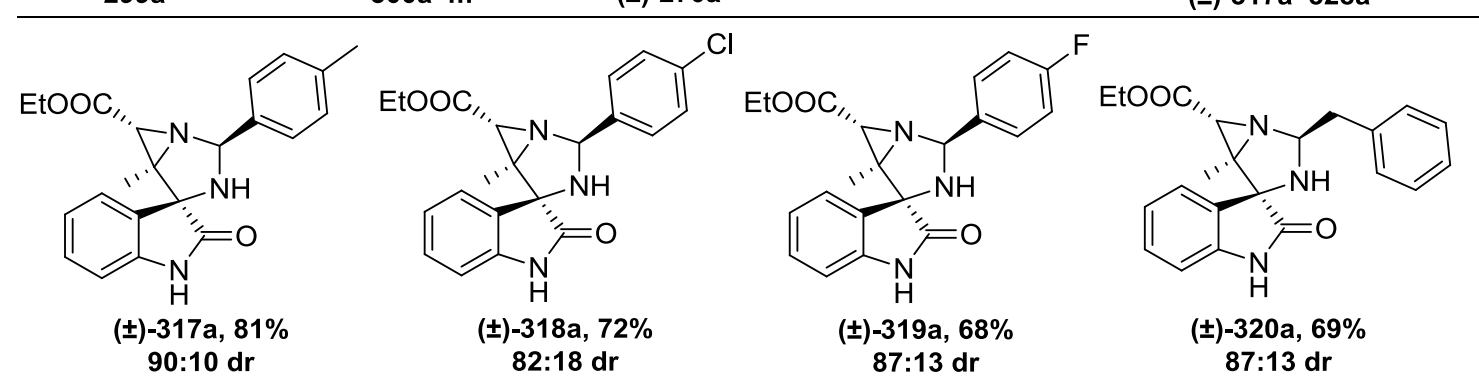

EtOOC,"<smiles>CC[C@H]1N[C@@]2(C(=O)Nc3ccccc32)[C@@H]2COC[C@H]12</smiles>

$( \pm)-321 a, 61 \%$ $81: 19 \mathrm{dr}$ EtOOC,,<smiles>CCO</smiles><smiles>O=C(O)[C@@H]1[C@@H]2N1[C@H](CCc1ccccc1)N[C@]21C(=O)Nc2ccccc21</smiles>

(士)-322a, 63\% $81: 19 \mathrm{dr}$ EtOOC,

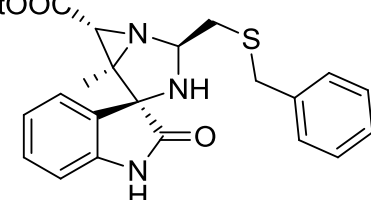

(士)-323a, 37\% 76:24 dr EtOOC,,

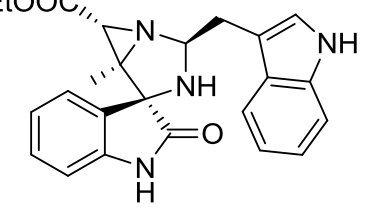

(士)-324a, 66\% $81: 19 \mathrm{dr}$

EtOOC,<smiles>C[C@]12[C@@H](C(=O)O)N1C(CO)N[C@@]21C(=O)Nc2ccccc21</smiles>

(士)-325a, 46\% $84: 16 \mathrm{dr}$<smiles>CCOC[C@H]1N2[C@@H](CCC(N)=O)N[C@]3(C(=O)Nc4ccccc43)[C@]12C</smiles>

(士)-326a, 56\% $80: 20 \mathrm{dr}$
EtOOC<smiles>CCCC[C@@H]1N[C@]2(C(=O)Nc3ccccc32)[C@@]2(C)[C@H](COC=O)N12</smiles>

(士)-327a, 70\% $82: 18 \mathrm{dr}$
EtOOC

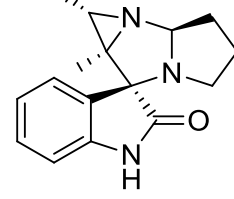

(士)-328a, $11 \%$ $89: 11 \mathrm{dr}$

Reakciókörülmények: izatin (0,5 mmol), aminosav (0,6 mmol), $2 \mathrm{H}$-azirin $(0,5 \mathrm{mmol}), 2 \mathrm{ml}$ vízmentes DMSO, argon, 60 ${ }^{\circ} \mathrm{C}, 8$ óra. A diasztereomer arányt (dr) a nyers reakcióelegyből vett minta LC-MS mérésével határoztuk meg. 
Tekintve a pirrolidin motívum kiemelt gyógyszerkémiai jelentőségét, ${ }^{197-200}$ a $( \pm)-328 a$ vegyület szintézisének reakciókörülményeit újravizsgáltuk (10. táblázat). Az izatin (299a), Lprolin (300m) és $( \pm)$-270a $2 H$-azirin háromkomponensủ reakciójának HPLC segítségével történő optimalizálása során először a megfelelő közeg kiválasztására fókuszáltunk (10. táblázat, 1-12. kísérlet). Szobahőmérsékleten, 24 óra reakcióidő után az izopropil-alkohol bizonyult a leghatékonyabb oldószernek (10. táblázat, 3. kísérlet, 44\%-os HPLC hozam, 93:7 dr). A 2Hazirin, majd az oldószer mennyiségének változtatásával (10. táblázat, 13-20. kísérlet) jelentős hozamnövekedést sikerült elérnünk (10. táblázat, 18. kísérlet, 68\%-os HPLC hozam). A reakciót alacsonyabb $\left(0^{\circ} \mathrm{C}\right)$, illetve magasabb $\left(60^{\circ} \mathrm{C}\right.$ és $\left.80^{\circ} \mathrm{C}\right)$ hőmérsékleten elvégezve a céltermék hozamának csökkenését tapasztaltuk (10. táblázat, 21-23. kísérlet).

10. táblázat. Reakciókörülmények újraoptimalizálása L-prolin aminosavra

\begin{tabular}{|c|c|c|c|c|c|c|c|}
\hline \multicolumn{2}{|c|}{$299 a$} & \multirow{2}{*}{$\begin{array}{l}300 \mathrm{~m} \\
\begin{array}{l}\text { Oldószer } \\
(\mathrm{ml})\end{array} \\
\end{array}$} & \multicolumn{2}{|c|}{ ( \pm )-270a } & \multirow[b]{2}{*}{$\begin{array}{l}( \pm)-270 a \\
\text { (ekv.) } \\
\end{array}$} & \multicolumn{2}{|c|}{$( \pm)-328 a$} \\
\hline Kísérlet & Oldószer & & $\begin{array}{l}\text { Hóm. } \\
\left({ }^{\circ} \mathbf{C}\right)\end{array}$ & Idő (óra) & & $\begin{array}{l}\text { Hozam } \\
(\%)^{a}\end{array}$ & $\mathbf{d r}^{b}$ \\
\hline 1 & $\mathrm{MeOH}$ & 1 & $\mathrm{rt}$ & 24 & 1 & 10 & 89:11 \\
\hline 2 & EtOH & 1 & $\mathrm{rt}$ & 24 & 1 & 25 & $90: 10$ \\
\hline 3 & IPA & 1 & rt & 24 & 1 & 44 & 93:7 \\
\hline 4 & TFE & 1 & $\mathrm{rt}$ & 24 & 1 & 6 & $51: 49$ \\
\hline 5 & $\mathrm{MeCN}$ & 1 & $\mathrm{rt}$ & 24 & 1 & 10 & $76: 24$ \\
\hline 6 & $\mathrm{MeNO}_{2}$ & 1 & $\mathrm{rt}$ & 24 & 1 & 5 & $68: 32$ \\
\hline 7 & DMF & 1 & $\mathrm{rt}$ & 24 & 1 & 28 & $92: 8$ \\
\hline 8 & EtOAc & 1 & $\mathrm{rt}$ & 24 & 1 & 2 & $65: 35$ \\
\hline 9 & THF & 1 & $\mathrm{rt}$ & 24 & 1 & 6 & $54: 46$ \\
\hline 10 & Toluol & 1 & $\mathrm{rt}$ & 24 & 1 & - & - \\
\hline 11 & $\mathrm{CHCl}_{3}$ & 1 & $\mathrm{rt}$ & 24 & 1 & 16 & $67: 33$ \\
\hline 12 & DKM & 1 & $\mathrm{rt}$ & 24 & 1 & 7 & 59:41 \\
\hline 13 & IPA & 1 & $\mathrm{rt}$ & 24 & 2 & 51 & $93: 7$ \\
\hline 14 & IPA & 1 & $\mathrm{rt}$ & 24 & 3 & 60 & $93: 7$ \\
\hline 15 & IPA & 0,25 & $\mathrm{rt}$ & 24 & 3 & 55 & $93: 7$ \\
\hline 16 & IPA & 0,5 & $\mathrm{rt}$ & 24 & 3 & 63 & $93: 7$ \\
\hline 17 & IPA & 1,5 & $\mathrm{rt}$ & 24 & 3 & 62 & $93: 7$ \\
\hline 18 & IPA & 2 & rt & 24 & 3 & 68 & 93:7 \\
\hline 19 & IPA & 2,5 & $\mathrm{rt}$ & 24 & 3 & 63 & $93: 7$ \\
\hline 20 & IPA & 3 & $\mathrm{rt}$ & 24 & 3 & 61 & $93: 7$ \\
\hline 21 & IPA & 2 & $0{ }^{\circ} \mathrm{C}$ & 48 & 3 & 58 & $93: 7$ \\
\hline 22 & IPA & 2 & $60{ }^{\circ} \mathrm{C}$ & 4 & 3 & 52 & $93: 7$ \\
\hline 23 & IPA & 2 & $80^{\circ} \mathrm{C}$ & 2,5 & 3 & 56 & $93: 7$ \\
\hline
\end{tabular}

Reakciókörülmények: izatin $(0,125 \mathrm{mmol})$, L-prolin $(0,15 \mathrm{mmol}), 2 \mathrm{H}$-azirin, vízmentes oldószer, argon. ${ }^{\text {[a] }}$ HPLCvel meghatározott hozam $\left(( \pm)-328 a\right.$ kalibrációjával). ${ }^{[b]}$ A diasztereomer arányt (dr) HPLC-vel határoztuk meg. 
$\mathrm{Az}$ újraoptimalizált reakciókörülmények között szintetizált ( \pm )-328a cikloaddukt szerkezetét ${ }^{1} \mathrm{H}$ - és ${ }^{13} \mathrm{C}$-NMR mellett HSQC, HMBC, COSY és NOESY kétdimenziós NMR technikák alkalmazásával igazoltuk. A molekula konfigurációját NOESY méréssel, egyértelmü NOE kölcsönhatások (a C-4'-H és C-7-H, a C-4'-H és C-2-H, valamint a C-7-H és a pirrolidin gyürü C-2-H, C-3-H, C-4-H protonjai közötti keresztcsúcsok) azonosításával határoztuk meg (59. ábra). Emellett tetrahidrofurán oldószerből történő egykristály növesztést követően a molekula NMR módszerekkel igazolt szerkezetét egy röntgenkrisztallográfiás felvétel is alátámasztotta (59. ábra), melynek ismeretében megállapítottuk, hogy a reakciókörülmények módosítása a reakció sztereokémiai kimenetelét nem befolyásolta.

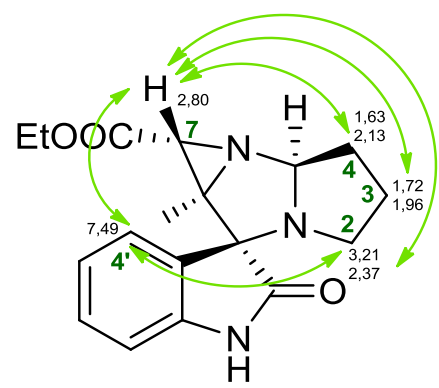

$( \pm)-328 a$

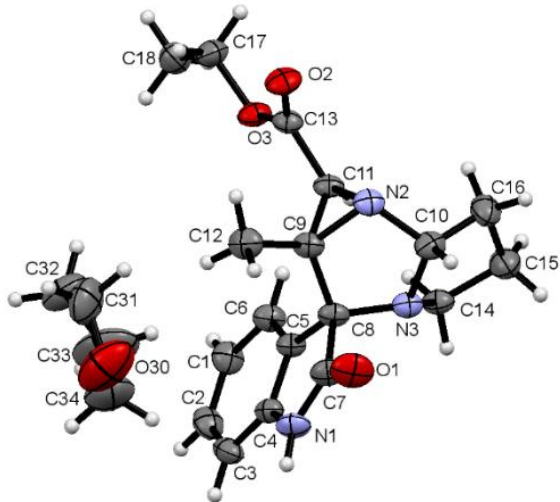

59. ábra. A ( $( \pm)$-328a cikloaddukt térszerkezetét meghatározó NOE csatolások és a molekula kristályszerkezete

Az L-prolinra optimalizált protokoll alkalmazhatóságát demonstrálva további öt analógot szintetizáltunk (11. táblázat). A ( $( \pm)$-328a-333a spirooxindol-imidazolidin származékokat többnyire magas diasztereoszelektivitás mellett (71:29-95:5 dr), közepes-jó hozammal (33$68 \%$ ) nyertük. A legalacsonyabb termeléseket meglepő módon a $( \pm)-270$ e difenilazirin esetén tapasztaltuk (( \pm$)$-332a és $( \pm)$-333a: 33\% és $47 \%)$. 
11. táblázat. L-prolin alkalmazása az újraoptimalizált reakciókörülmények között

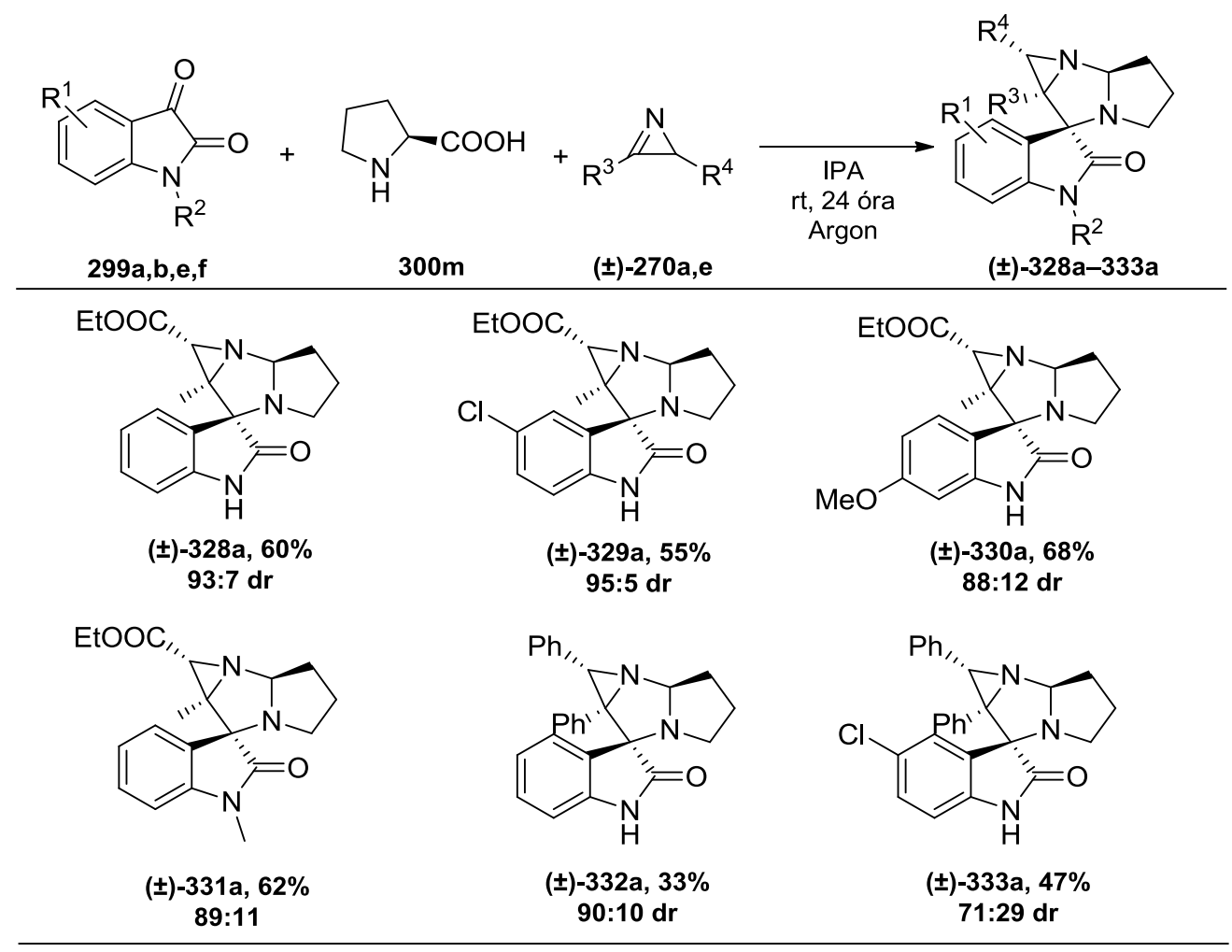

Reakciókörülmények: izatin (0,5 mmol), L-prolin ( $0,6 \mathrm{mmol}), 2 \mathrm{H}$-azirin $(1,5 \mathrm{mmol}), 8 \mathrm{ml}$ vízmentes IPA, argon, rt, 24 óra. A diasztereomer arányt (dr) a nyers reakcióelegyből vett minta LC-MS mérésével határoztuk meg.

Végül a fent ismertetett kísérleti és analitikai eredmények alapján a reakció mechanizmusára javaslatot tettünk, melyet a ( $( \pm)$-301a és $( \pm)$-301b vegyületek képződéséhez vezető modellreakción keresztül mutatok be (60. ábra). Az első lépésben az izatin (299a) és a fenilglicin (300a) kondenzációs (I.), ciklizációs (II.) majd dekarboxileződési (III.) reakcióján keresztül a C azometin-ilid képződik. Ezt követi a ( \pm -270a $2 H$-azirin 1,3-dipoláris cikloaddíciós reakciója, mely endo és exo átmeneti állapoton keresztül is végbemehet, azonban a $( \pm)-301 c$ exo termék képződésére nem találtunk bizonyítékot, mely feltételezhetően az azirin metilcsoportja és az oxindol fenilcsoportja között fellépő sztérikus gátlásra vezethető vissza. A ( \pm )-301a és $( \pm)$ 301b endo cikloadduktok képződése S- és U-alakú azometin-ilidek ${ }^{201}$ részvételével magyarázható, azonban a két konformer közötti stabilitás-különbség eredményeként a reakció főterméke a ( \pm )-301a diasztereomer. 


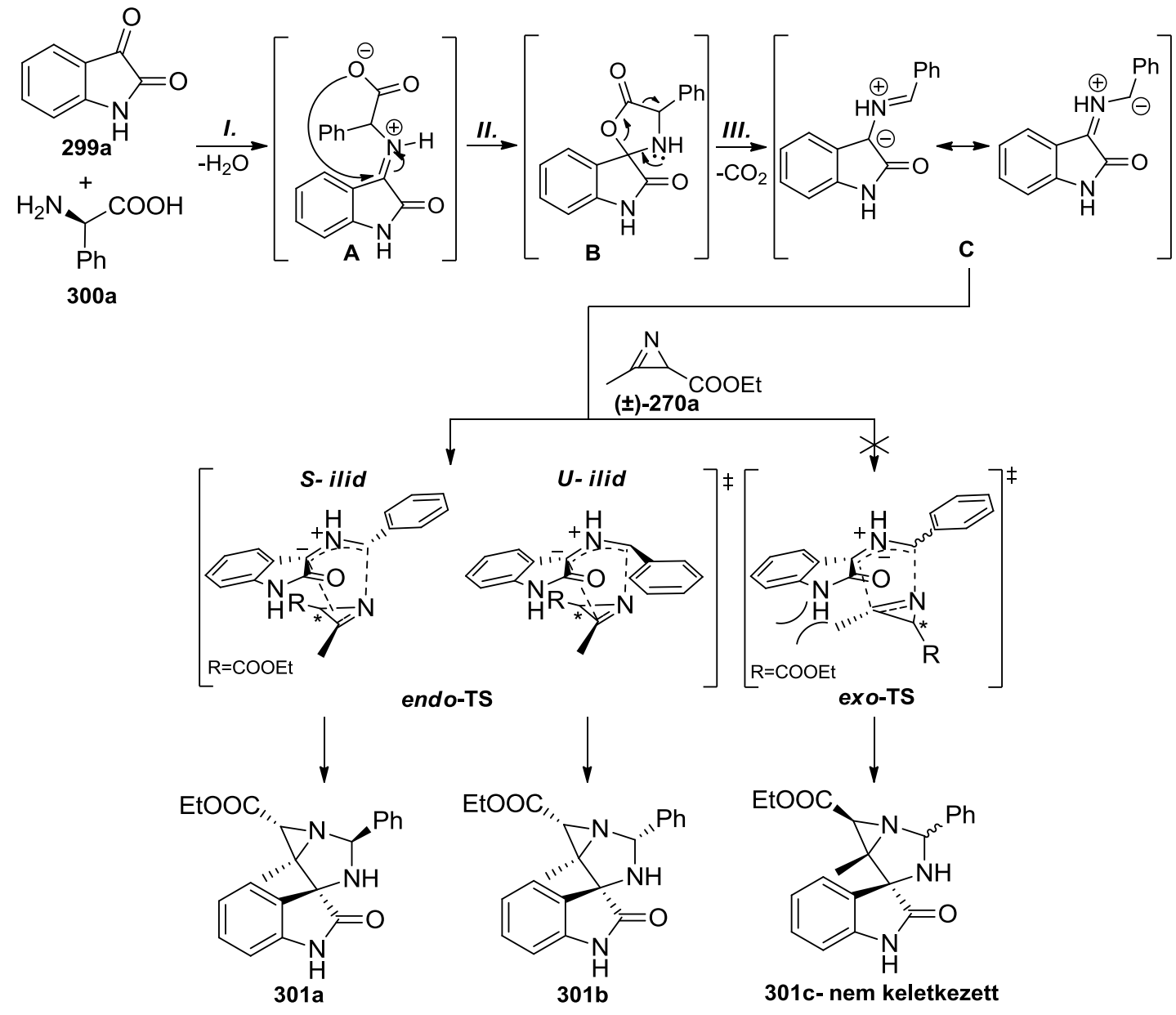

60. ábra. Feltételezett reakciómechanizmus

Az Avidin Kft. biológus munkatársai az előállított ( \pm -301a- $( \pm)-333 a$ spirooxindolimidazolidin származékokat in vitro citotoxicitási vizsgálatoknak vetették alá A549 humán tüdőkarcinóma, MCF7 humán emlőkarcinóma és 3T3 egér fibroblaszt sejtvonalakon. A vegyületek többsége $20 \mu \mathrm{M}$-nál nagyobb $\mathrm{IC}_{50}$ értékkel rendelkezett, vagy a tesztelt koncentrációtartományban $(1-30 \mu \mathrm{M})$ inaktívnak bizonyult, csupán a 270i azirinböl és fenilglicinből képzett $( \pm)$-310a, $( \pm)$-315a és $( \pm)$-316a analógok mutattak egyes sejtvonalakon mérsékelt tumorellenes hatást $\left(\mathrm{IC}_{50} \approx 10 \mu \mathrm{M}\right)(61$. ábra). 


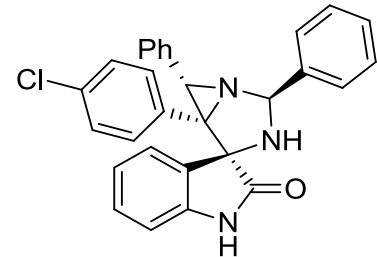

$( \pm)-310 a$

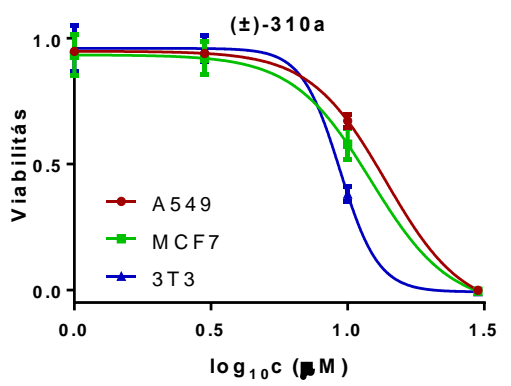

\begin{tabular}{c|ccc}
\hline & A549 & MCF7 & 3T3 \\
\hline $\begin{array}{c}\text { IC50 } \\
(\boldsymbol{\mu M})\end{array}$ & 13,8 & 12,2 & 9,4 \\
\hline
\end{tabular}

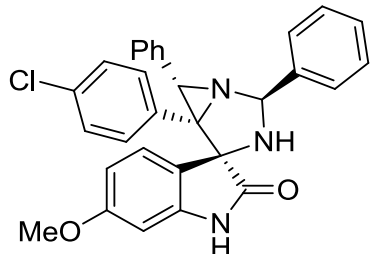

$( \pm)-315 a$

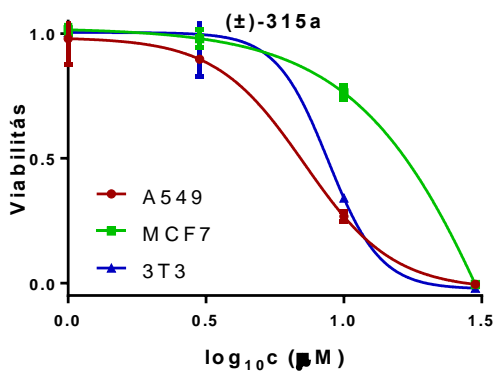

\begin{tabular}{c|ccc}
\hline & A549 & MCF7 & 3T3 \\
\hline $\begin{array}{c}\text { IC50 }_{50} \\
(\boldsymbol{\mu M})\end{array}$ & 7,2 & $>20$ & 8,8 \\
\hline
\end{tabular}

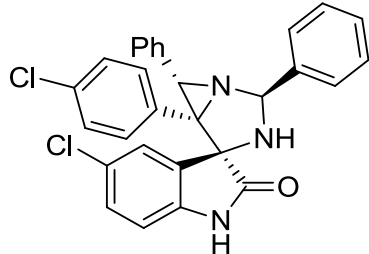

$( \pm)-316 a$

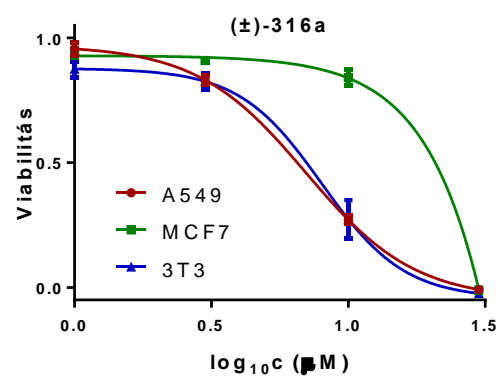

\begin{tabular}{c|ccc}
\hline & A549 & MCF7 & 3T3 \\
\hline $\begin{array}{c}\text { IC } 50 \\
(\boldsymbol{\mu M})\end{array}$ & 7,0 & $>20$ & 8,0 \\
\hline
\end{tabular}

61. ábra. $A( \pm)-310 a,( \pm)-315 a$ és $( \pm)-316 a$ vegyületek citotoxikus aktivitása

\subsection{Tetraszubsztituált imidazolok szintézise ${ }^{202}$}

A 2H-azirinek és nitronok közötti 1,3-dipoláris cikloaddíció megvalósítására irányuló kísérleti munkánk kezdetén a ( $( \pm)-270 a$ azirin és a 334a nitron reakcióját vizsgáltuk vízmentes acetonitrilben (12. táblázat, 1. kísérlet). Mivel konverziót nem tapasztaltunk, az azirin reakcióképességének növelése érdekében számos Brønsted- és Lewis-sav katalizátort teszteltünk szobahőmérsékleten és $60{ }^{\circ} \mathrm{C}$-on (12. táblázat, 2-31. kísérlet, illetve Melléklet: M1. táblázat: konverziók és hozamok 8 és 24 óránál). A ( \pm )-270a és 334a reakcióját a katalizátorok többsége ugyan elősegítette, azonban meglepő módon a várt 335 cikloaddukt helyett a 336 imidazol képződött. Az alkalmazott savak közül a TFA bizonyult a leghatékonyabbnak, mellyel szobahőmérsékleten 62\% HPLC hozamot értünk el (12. táblázat, 4. kísérlet). Más Brønstedsavak, mint például a perklórsav és a PTSA a 336 terméket hasonló hozammal eredményezték (12. táblázat, 6. és 7. kísérlet), míg ecetsav és szilárd savak gyenge katalitikus aktivitást mutattak (12. táblázat, 3. és 13-15. kísérlet). A vizsgált Lewis-savak közül csak a $\operatorname{Mg}(\mathrm{OTf})_{2}, \mathrm{Yb}(\mathrm{OTf})_{3}$, $\mathrm{Sc}(\mathrm{OTf})_{3}$ és a $\mathrm{Dy}(\mathrm{OTf})_{3}$ mutatott jelentős aktivitást (12. táblázat, 28-31. kísérlet), míg a cink-, indium-, vas- és réz-sók kevésbé bizonyultak hatásosnak (12. táblázat, 16-27. kísérlet). Fontos megemlíteni, hogy a nyers reakcióelegyek LC-MS-elemzése során nem találtunk bizonyítékot arra, hogy a 336 imidazolon kívül más izomer vagy a 335 cikloaddukt is képződött volna. 
12. táblázat. Savak hatása a modellreakcióra

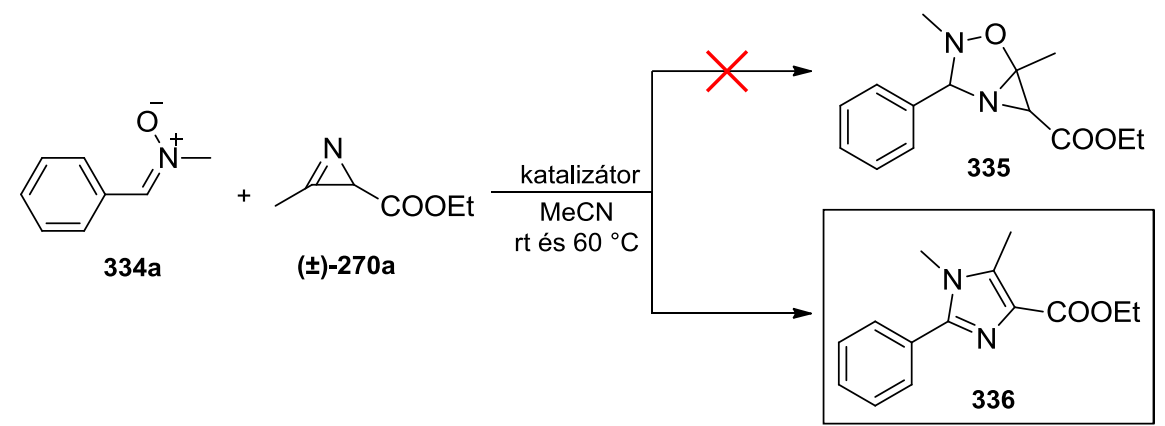

\begin{tabular}{|c|c|c|c|}
\hline Kísérlet & Katalizátor & Hozam-rt $(\%)^{a}$ & Hozam-60 ${ }^{\circ} \mathrm{C}(\%)^{a}$ \\
\hline 1 & - & 0 & 0 \\
\hline 2 & $\mathrm{HCOOH}$ & 36 & 42 \\
\hline 3 & $\mathrm{AcOH}$ & 0 & 17 \\
\hline 4 & TFA & 62 & 50 \\
\hline 5 & $\mathrm{MeSO}_{3} \mathrm{H}$ & 52 & 42 \\
\hline 6 & $\mathrm{PTSA} \times \mathrm{H}_{2} \mathrm{O}$ & 57 & 44 \\
\hline 7 & $\mathrm{HClO}_{4}(70 \%)$ & 56 & 48 \\
\hline 8 & $\mathrm{H}_{2} \mathrm{SO}_{4}$ & 49 & 41 \\
\hline 9 & $\mathrm{NaHSO}_{4}$ & 28 & 30 \\
\hline 10 & $\mathrm{~B}(\mathrm{OH})_{3}$ & 35 & 39 \\
\hline 11 & $\mathrm{PTA}^{\dagger}$ & 54 & 49 \\
\hline 12 & BINOL-foszforsav $v^{\dagger \dagger}$ & 52 & 43 \\
\hline 13 & Szilikagél $^{b, c}$ & 16 & 41 \\
\hline 14 & Amberlyst $15^{b}$ & 1 & 1 \\
\hline 15 & Montmorillonit $\mathrm{K} 10^{b}$ & 22 & 22 \\
\hline 16 & $\mathrm{ZnCl}_{2}$ & 8 & 22 \\
\hline 17 & $\mathrm{Zn}(\mathrm{OAc})_{2}$ & 7 & 9 \\
\hline 18 & $\mathrm{ZnF}_{2}$ & 0 & 22 \\
\hline 19 & $\mathrm{InCl}_{3}$ & 12 & 21 \\
\hline 20 & $\operatorname{In}(\mathrm{OAc})_{3}$ & 2 & 20 \\
\hline 21 & $\operatorname{In}(\mathrm{OTf})_{3}$ & 39 & 35 \\
\hline 22 & $\mathrm{FeCl}_{2} \times 4 \mathrm{H}_{2} \mathrm{O}$ & 4 & 31 \\
\hline 23 & $\mathrm{FeCl}_{3} \times 6 \mathrm{H}_{2} \mathrm{O}$ & 7 & 20 \\
\hline 24 & $\mathrm{CuCl}$ & 2 & 13 \\
\hline 25 & $\mathrm{CuCl}_{2}$ & 3 & 16 \\
\hline 26 & $\mathrm{Cu}(\mathrm{OAc})_{2}$ & 2 & 2 \\
\hline 27 & $\mathrm{Cu}(\mathrm{OTf})_{2}$ & 12 & 23 \\
\hline 28 & $\operatorname{Mg}(\mathrm{OTf})_{2}$ & 56 & 37 \\
\hline 29 & $\mathrm{Yb}(\mathrm{OTf})_{3}$ & 57 & 39 \\
\hline 30 & $\mathrm{Sc}(\mathrm{OTf})_{3}$ & 56 & 42 \\
\hline 31 & $\mathrm{Dy}(\mathrm{OTf})_{3}$ & 59 & 39 \\
\hline
\end{tabular}

Reakciókörülmények: nitron ( $0,10 \mathrm{mmol}), 2 \mathrm{H}$-azirin $(0,10 \mathrm{mmol})$, vízmentes $\mathrm{MeCN}(0,3 \mathrm{ml})$, katalizátor (10 mol\%), 24 óra.

${ }^{[\mathrm{a}]}$ HPLC-MS méréssel meghatározott hozamok (336 kalibrációjával). ${ }^{[\mathrm{b}]} 10 \mathrm{w} / \mathrm{v} \%$-ot alkalmaztunk. ${ }^{[\mathrm{c}]} 60$ A, 70-230 mesh. ‘'Foszfor-volfrámsav. ${ }^{\dagger \dagger} 1,1^{\prime}$-Binaftil-2,2'-diil-hidrogén-foszfát. 
A reakciókörülmények további optimalizálása érdekében különböző oldószereket teszteltünk szobahőmérsékleten TFA (10 mol\%) katalizátor jelenlétében (13. táblázat, 1-13. kísérlet, illetve Melléklet: M2. táblázat: konverziók és hozamok 3, 8 és 24 óránál). A reakció aprotikus oldószerekben bizonyult a leghatékonyabbnak, míg fluortartalmú alkoholok vagy DMSO alkalmazása alacsony hozamokat eredményezett. A legmagasabb HPLC hozamot (62\%) acetonitrilben értük el (13. táblázat, 13. kísérlet), melyet feleslegben használt azirinnel (1,5ekv.) 74\%-ra növeltünk (13. táblázat, 15. kísérlet). A katalizátor mennyiségének csökkentése, illetve növelése ezzel szemben a hozam fokozatos csökkenésével járt (13. táblázat, 17-22. kísérlet, illetve Melléklet: M3. táblázat: konverziók és hozamok 3, 8 és 24 óránál). Végül a reakciót 60 ${ }^{\circ} \mathrm{C}$-on, 1,5 ekvivalens azirin és $10 \mathrm{~mol} \%$ TFA mellett elvégezve a várt termék rövidebb reakcióidő alatt (6 óra), 78\%-os HPLC hozammal keletkezett (13. táblázat, 24. kísérlet).

13. táblázat. A modellreakció optimalizálása

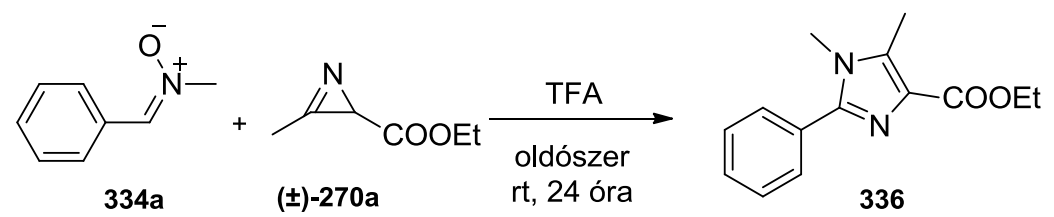

\begin{tabular}{|c|c|c|c|c|}
\hline Kísérlet & Oldószer & Azirin (ekv.) & Katalizátor (mol \%) & $\operatorname{Hozam}(\%)^{a}$ \\
\hline 1 & $\mathrm{MeOH}$ & 1,0 & 10 & 39 \\
\hline 2 & $\mathrm{EtOH}$ & 1,0 & 10 & 46 \\
\hline 3 & IPA & 1,0 & 10 & 33 \\
\hline 4 & $\mathrm{TFE}^{b}$ & 1,0 & 10 & 14 \\
\hline 5 & $\mathrm{HFIP}^{b}$ & 1,0 & 10 & 3 \\
\hline 6 & $\mathrm{CHCl}_{3}$ & 1,0 & 10 & 39 \\
\hline 7 & $\mathrm{CH}_{2} \mathrm{Cl}_{2}$ & 1,0 & 10 & 60 \\
\hline 8 & toluol & 1,0 & 10 & 42 \\
\hline 9 & THF & 1,0 & 10 & 54 \\
\hline 10 & dioxán & 1,0 & 10 & 47 \\
\hline 11 & DMF & 1,0 & 10 & 48 \\
\hline 12 & DMSO & 1,0 & 10 & 13 \\
\hline 13 & $\mathrm{MeCN}$ & 1,0 & 10 & 62 \\
\hline 14 & $\mathrm{MeCN}$ & 1,25 & 10 & 70 \\
\hline 15 & $\mathrm{MeCN}$ & 1,5 & 10 & 74 \\
\hline 16 & $\mathrm{MeCN}$ & 2,0 & 10 & 74 \\
\hline 17 & $\mathrm{MeCN}$ & 1,5 & 1 & 43 \\
\hline 18 & $\mathrm{MeCN}$ & 1,5 & 2,5 & 60 \\
\hline 19 & $\mathrm{MeCN}$ & 1,5 & 5 & 73 \\
\hline 20 & $\mathrm{MeCN}$ & 1,5 & 15 & 72 \\
\hline 21 & $\mathrm{MeCN}$ & 1,5 & 20 & 68 \\
\hline 22 & $\mathrm{MeCN}$ & 1,5 & 40 & 41 \\
\hline $23^{c}$ & $\mathrm{MeCN}$ & 1,5 & 5 & 69 \\
\hline $24^{c}$ & $\mathrm{MeCN}$ & 1,5 & 10 & 78 \\
\hline
\end{tabular}

Reakciókörülmények: nitron $(0,10 \mathrm{mmol}), 2 H$-azirin $(0,10-0,20 \mathrm{mmol})$, vízmentes oldószer $(0,3 \mathrm{ml})$, katalizátor (1-40 mol\%).

${ }^{[a]}$ HPLC-MS méréssel meghatározott hozamok (336 kalibrációjával). ${ }^{[b]}$ Nem vízmentes. ${ }^{[c]} 60{ }^{\circ} \mathrm{C}, 6$ óra. 
Az optimális reakciókörülmények (1,5 ekv. ( $( \pm)-270 a, 10$ mol\% TFA, vízmentes MeCN, $60{ }^{\circ} \mathrm{C}, 6$ óra) beállítását követően a $( \pm)-270 a$ $2 H$-azirint különböző $N$-metilnitronokkal reagáltattuk (14. táblázat, 1-13. kísérlet). A szubsztituálatlan, valamint az elektronküldő MeO vagy elektronszívó $\mathrm{F}$ és $\mathrm{NO}_{2}$ szubsztituenseket tartalmazó 334a-d $C$-fenilnitronok az aromás gyürü elektronikus sajátságától függetlenül jó hozammal (68-78\%) eredményezték a megfelelö 336-339 termékeket. A reakció heteroaromás $N$-metilnitronokra is kiterjeszthető, melyet a 340342 2-piridil-és 2-furilimidazolok szintézisével szemléltettünk (14. táblázat, 5-7. kísérlet, 4182\%). A kifejlesztett módszer $C$-alifás $N$-metilnitronokkal egyaránt kompatibilis, melyek közepes-jó hozammal (49-72\%) szolgáltatták a kívánt 343-348 multiszubsztituált imidazolokat. Érdemes azonban megjegyezni, hogy az alifás $C$-szubsztituensek növekvő térigényével párhuzamosan többnyire alacsonyabb hozamokat tapasztaltunk (például $\mathrm{R}^{1}=i$-Pr: $53 \%$; $\mathrm{R}^{1}=t$ $\mathrm{Bu}: 49 \%)$. Az $N$-szubsztituens $\left(\mathrm{R}^{2}\right)$ reakció hatékonyságára gyakorolt hatását vizsgálva néhány $N$-alifás- és egy $N$-arilnitront is teszteltünk (14. táblázat, 14-18. kísérlet). Érdekes módon míg a 334n-p $N$-izopropil- és $N$-benzilnitronokkal jó hozamokat értünk el (349-351: 55-71\%), a megfelelő $352 N$-ciklohexil- és $353 N$-4-fluor-fenilimidazol származékokat alacsonyabb termeléssel állítottuk elő ( $37 \%$ és $42 \%)$.

14. táblázat. Nitronok tesztelése az imidazolszintézisben

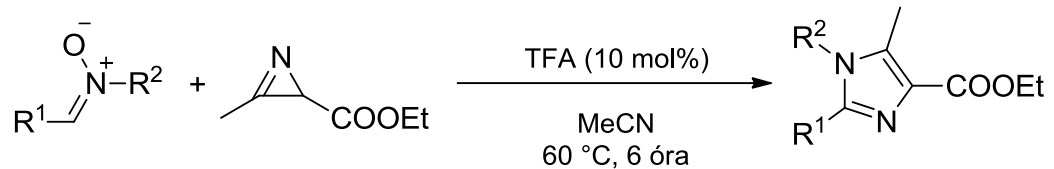

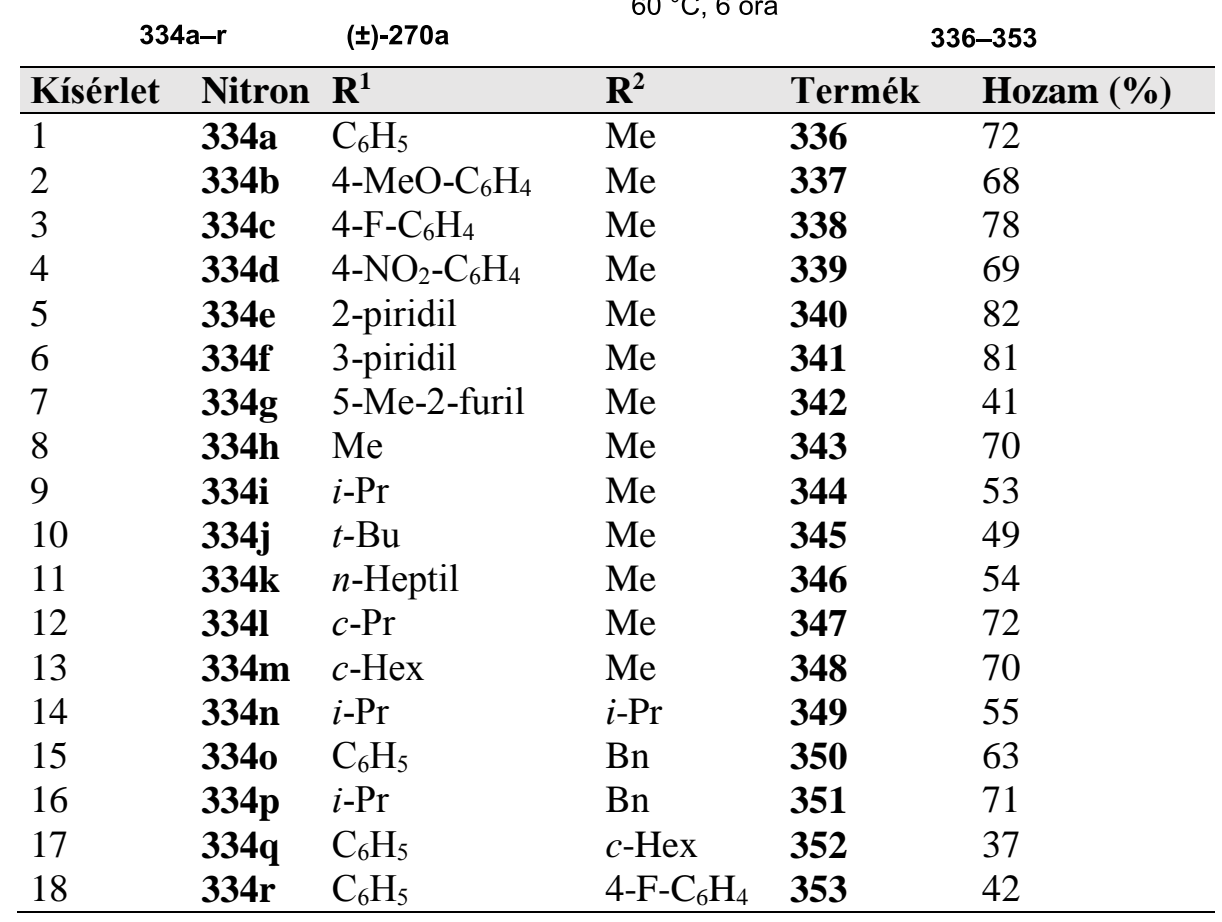

Reakciókörülmények: nitron (1 mmol), $2 \mathrm{H}$-azirin (1,5 mmol), vízmentes MeCN (3 ml), TFA (10 mol\%), $60{ }^{\circ} \mathrm{C}, 6$ óra. 
A kísérleti munka következő fázisában különböző azirinek alkalmazhatóságát vizsgáltuk, melyeket a megbízhatóbb összehasonlíthatóság érdekében egy $C$-aromás, illetve egy $C$-alifás $N$ metilnitronnal (334a és 334i) reagáltattunk (15. táblázat). Várható módon a $( \pm)-270 b$ tercbutoxikarbonil-csoporttal 2-szubsztituált $2 \mathrm{H}$-azirin a megfelelő imidazolokat hasonló hozammal eredményezte (15. táblázat. 354: 67\% és 361: 49\%), mint a ( \pm )-270a etoxikarbonil analóg (14. táblázat. 336: 72\% és 344: 53\%). Az eljárás 4,5-diaril-imidazolok szintézisére is alkalmas, melyet a $( \pm)-270$ e,g-i 2,3-difenilazirinek 355-358 és 362-355 céltermékekké történő, jó hozamú (67-79\%) átalakításával bizonyítottunk. Érdemes megjegyezni, hogy ugyan jelentős szubsztituenshatást nem tapasztaltunk, a legjobb termeléseket az elektronvonzó $\mathrm{F}$ és $\mathrm{Cl}$ atommal rendelkező azirinekkel értük el. Ezzel szemben a $( \pm)$-270f benzilazirin alkalmazásakor alacsonyabb izolált hozamokat értünk el (359: 45\% és 366: 57\%), a monoszubsztituált ( $( \pm)$-270j azirin esetében pedig komplex reakcióelegyekhez jutottunk, melyekben csupán nyomnyi mennyiségben detektáltuk (HPLC-MS) a kívánt 360 és 367 imidazolokat.

15. táblázat. $2 H$-azirinek tesztelése az imidazolszintézisben
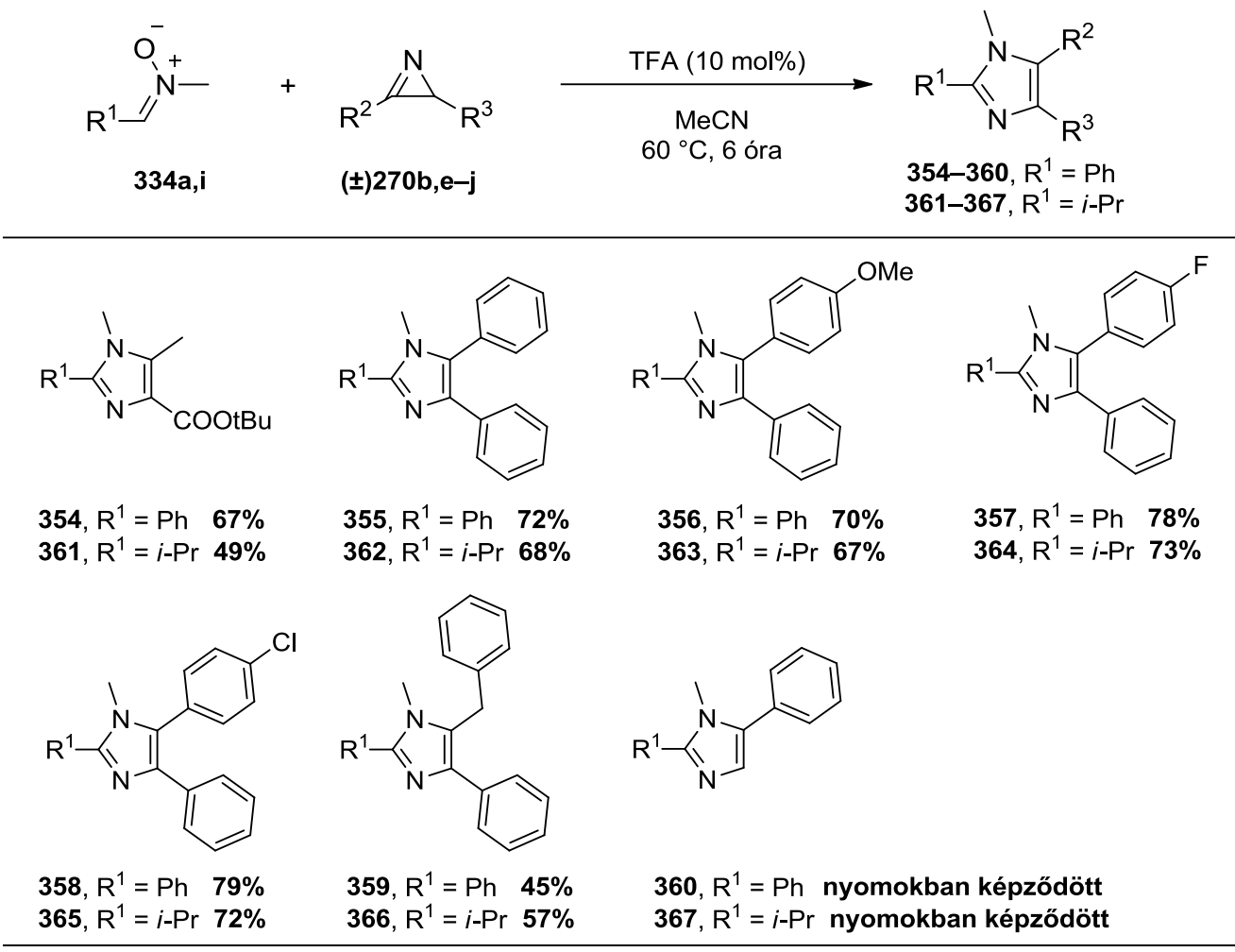

Reakciókörülmények: nitron ( $1 \mathrm{mmol}), 2 \mathrm{H}$-azirin (1,5 mmol), vízmentes $\mathrm{MeCN}$ (3 ml), TFA (10 mol\%), 60 ${ }^{\circ} \mathrm{C}, 6$ óra. 
A módszer általánosságának alaposabb vizsgálata érdekében a $( \pm)$-270e aromás azirin reaktivitását néhány másik, korábban már alkalmazott nitronnal is teszteltük (16. táblázat). $C$-aromás és a $C$-alifás $N$-metil-nitronok a várt 4,5-difenil-imidazol származékokat közepes-jó hozammal (50-79\%) szolgáltatták (16. táblázat, 368-373). Érdemes megjegyezni, hogy a legalacsonyabb izolált hozamot ismét a nagy térkitöltésű terc-butilcsoporttal szubsztituált $\left(\mathrm{R}^{1}\right)$ nitron eredményezte (371: 50\%). Az $N$-izopropil és $N$-ciklohexil szubsztituált 334n és 334q nitronokkal a reakció alacsonyabb termeléssel ment végbe (16. táblázat, 374: 24\% és 375: 32\%), mely feltételezhetően sztérikus okokra vezethető vissza. Ezzel szemben a $334 p ~ N$-benzilnitron alkalmazásával kiváló, 83\%-os izolált hozammal nyertük a 376 terméket, mely a fenti feltételezést erősíti.

16. táblázat. Nitronok tesztelése a $( \pm)$-270e aromás azirinnel

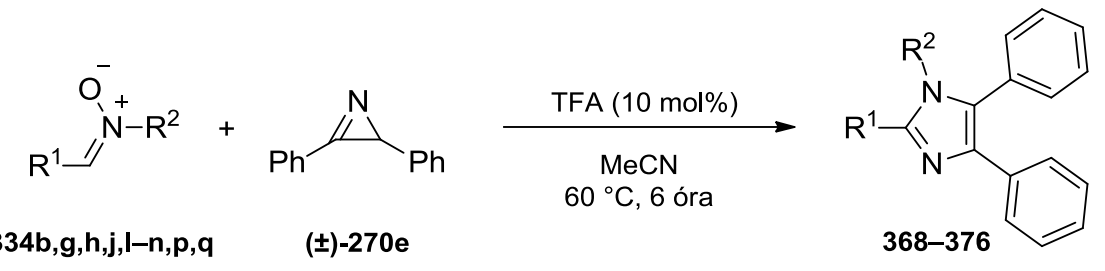

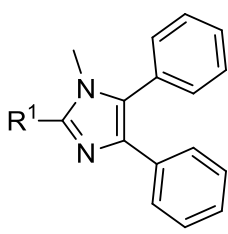

368, $\mathrm{R}^{1}=4-\mathrm{MeO}-\mathrm{C}_{6} \mathrm{H}_{4} \quad 69 \%$ 269, $R^{1}=5-$-Me-2-furil $59 \%$ $370, \mathrm{R}^{1}=\mathrm{Me} 69 \%$ 371, $\mathrm{R}^{1}=t-\mathrm{Bu} \quad 50 \%$ 372, $\mathrm{R}^{1}=c-\operatorname{Pr} 58 \%$ 373, $\mathrm{R}^{1}=c-\mathrm{Hex} 79 \%$

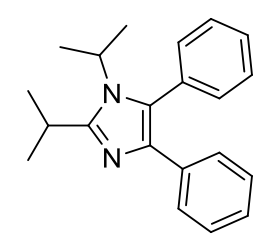

$374,24 \%$

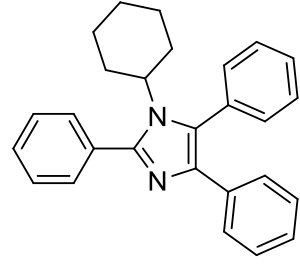

$375,32 \%$

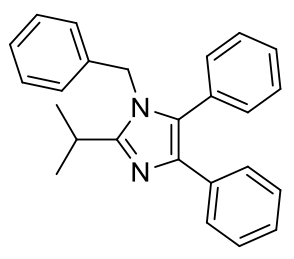

$376,83 \%$

Reakciókörülmények: nitron ( $1 \mathrm{mmol}), 2 \mathrm{H}$-azirin $(1,5 \mathrm{mmol})$, vízmentes $\mathrm{MeCN}(3 \mathrm{ml})$, TFA $(10 \mathrm{~mol} \%), 6{ }^{\circ} \mathrm{C}, 6$ óra.

Az előállított 336-376 vegyületek szerkezetigazolása minden esetben 1D-NMR ( ${ }^{1} \mathrm{H}$ - és ${ }^{13} \mathrm{C}-\mathrm{NMR}$ ) és tömegspektrometriai mérésekkel történt. A 336 modellvegyület esetében az egydimenziós ${ }^{1} \mathrm{H}$ - és ${ }^{13} \mathrm{C}-\mathrm{NMR}$ spektrumokon HSQC, HMBC és NOESY kétdimenziós NMR technikák segítségével teljes jelhozzárendelést végeztünk (62. ábra). A termék spektrumában az azirinből származó részegységek, úgymint az etilészter $\left(\mathrm{CH}_{2}: 4,25\right.$ ppm, q; $\mathrm{CH}_{3}: 1,29$ ppm, t) és a metilcsoport (2,54 ppm, s), valamint a nitronhoz tartozó $N$-metil (3,60 ppm, s) és fenil (7,64 ppm, d, 2H; 7,55-7,46, m, 3H) funkciók egyértelműen azonosíthatók. A ${ }^{13} \mathrm{C}-\mathrm{NMR}$ spektrumon a fent említett részegységekhez tartozó jeleken túl az imidazol vázrendszer szénatomjait (C-2: 146,9 ppm; C-4: 128,0 ppm; C-5: 138,1 ppm) is azonosítottuk. 

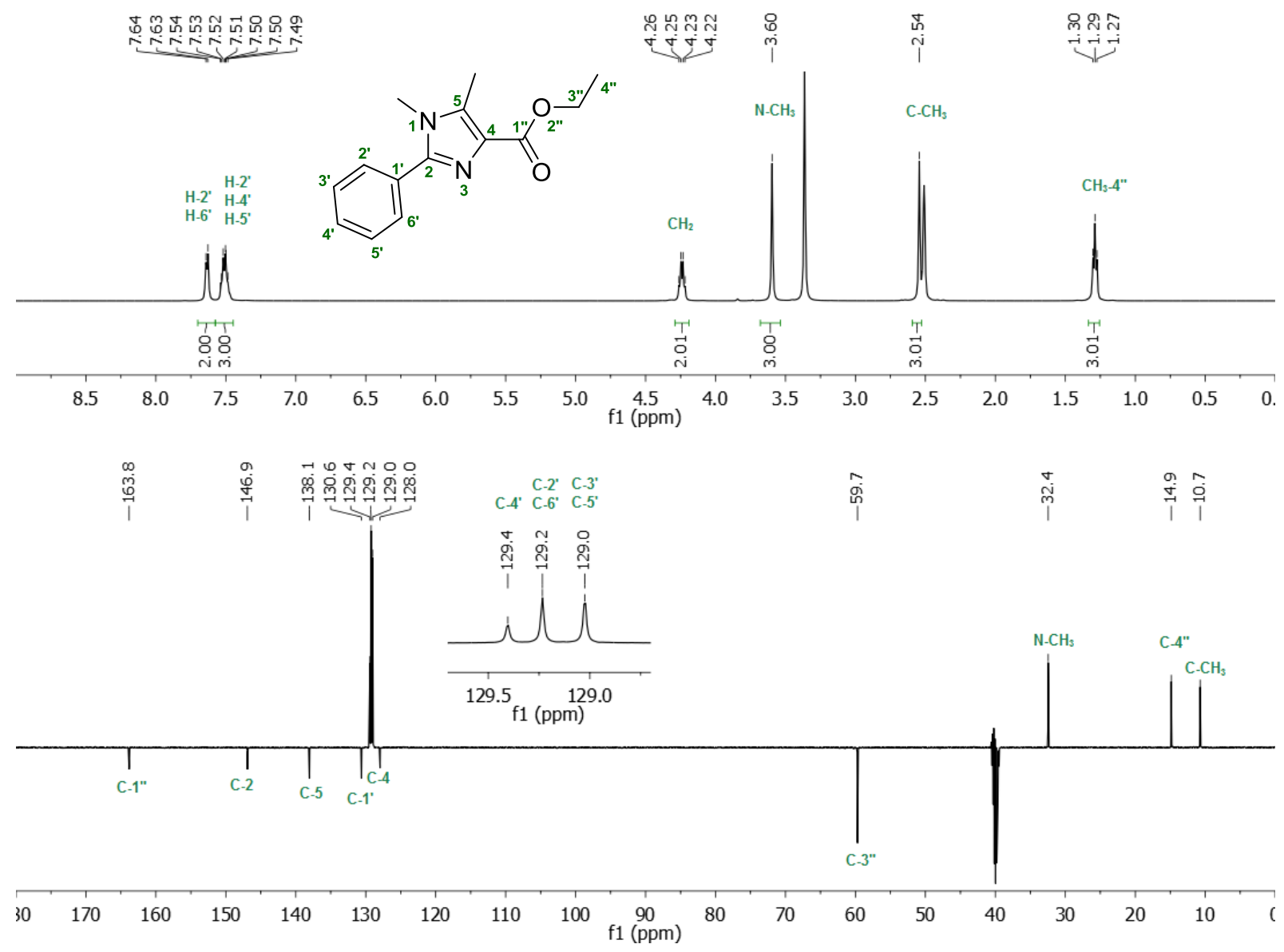

62. ábra. A 336 imidazol ${ }^{1} \mathrm{H}$ - és ${ }^{13} \mathrm{C}-\mathrm{NMR}$ spekrtumai (DMSO- $d_{6}$ )

A szerkezetigazolás során két regioizomer keletkezésének lehetőségét tartottuk szem előtt (63. ábra, 336A és 336B izomerek), melyek között NOESY méréssel - az $N$-metil- (3,60 ppm) és a C-5 metilcsoport között megjelenő intenzív keresztcsúcs alapján - tettünk különbséget.
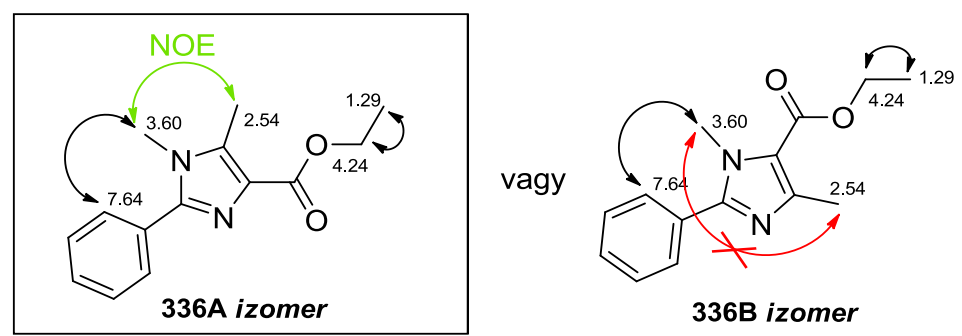

63. ábra. A lehetséges regioizomerek szerkezete és az azonosított NOE korrelációk 
Végül a kísérleti és analitikai eredmények alapján a reakció mechanizmusára javaslatot tettünk (64. ábra). Az első lépésben feltehetőleg a ( \pm )-270 azirin és a 334 nitron 1,3-dipoláris cikloaddíciója révén az $\mathbf{A}$ biciklus jön létre, mely a savkatalizátor jelenlétében a $\mathbf{B}$ aminoketonná rendeződik át. Ezt követően egy intramolekuláris gyürüzárással a $\mathbf{C}$ köztitermék alakul ki, melyből vízkilépéssel képződik a 334-376 tetraszubsztituált imidazol.

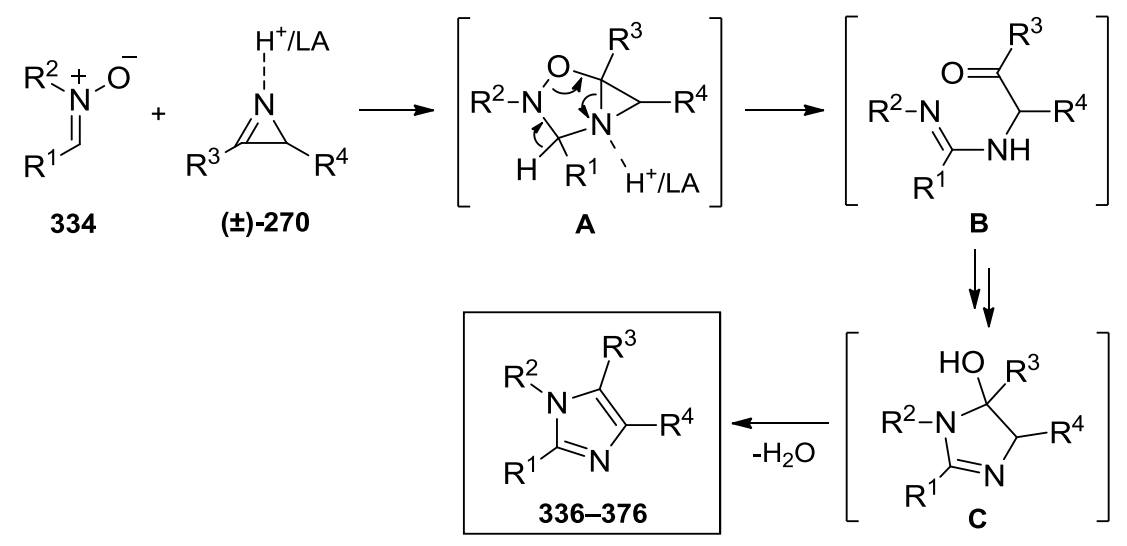

64. ábra. Az imidazolszintézis feltételezett reakciómechanizmusa 


\section{5. Általános kísérleti rész}

Az NMR spektrumok felvétele Bruker Avance 500 vagy Bruker Ascend 500 készülékkel, $298 \mathrm{~K}$ hőmérsékleten történt, a TMS vagy az oldószer jelét használva belső standardként. A mérések során deuterált $\mathrm{CDCl}_{3}$ vagy DMSO- $d_{6}$ oldószereket alkalmaztunk (a megfelelő adatoknál jelölve).

A nagyfelbontású tömegspektrumok (HRMS) Thermo Scientific Q Exactive Plus spektrométerrel, HESI ionizációs technikával, pozitív ion módban készültek.

A HPLC-MS méréseket Waters SQ vagy Agilent G1946D MS detektorral (ESI vagy APCI ionizációs technikával, pozitív módban müködtetve) kapcsolt Agilent 1100/1200 típusú készüléken végeztük, Luna C18 (2) (100 Å, $10 \mu \mathrm{m}, 250$ x 4,6 mm, Phenomenex) vagy Kinetex C18 oszlopon (100 A, $5 \mu \mathrm{m}, 250$ x 4,6 mm, Phenomenex). Az enantiomer felesleget (ee) királis HPLC analízissel határoztuk meg Shimadzu LC-10 VP típusú készülékkel, Lux Cellulose-1 oszlopon ( $5 \mu \mathrm{m}, 150$ x 4,6 mm, Phenomenex).

Az optikai forgatóképességet Optical Activity AA-55 polariméterrel (Optical Activity Ltd.) mértük meg.

Az olvadáspontokat Opti Melt Automated Melting Point System (SRS, Stanford research system) vagy Digital Melting Point Apparatus (Electrothermal, IA 9000) típusú olvadáspontmérővel, korrekció nélkül határoztuk meg.

A mikrohullámú reakciókat CEM Discover készülékkel hajtottuk végre.

Az oszlopkromatográfiás elválasztások szilikagél (Merck, $60 \AA$ A 0,063-0,200mm) állófázison történtek. A flash-kromatográfiás elválasztásokat Teledyne Isco CombiFlash Rf készülékkel, szilikagéllel töltött RediSep Rf oszlopok felhasználásával végeztük.

A reakciók lefutását vékonyréteg-kromatográfiával követtük, melyhez szilikagél lapokat (Merck, Kieselgel $60 \mathrm{~F}_{254}$ ) használtunk. Az alkalmazott eluenseket a vegyületek Rf-értékeinél jelöltük. A kromatogramokat UV-fénnyel (254 vagy $365 \mathrm{~nm}$ ), $\mathrm{KMnO}_{4}$ oldattal vagy jódgőzzel hívtuk elő. 


\section{Részletes kísérleti rész}

\subsection{A $( \pm)-270 a-c$ c $H$-azirin-2-karboxilátok előállításának általános leírása}

A ( \pm )-270a-c vegyületek szintézisét szakirodalom alapján, ${ }^{188,189}$ módosított körülményekkel végeztük.

A megfelelő $\beta$-ketoésztert (271a-c, 13,5 mmol) hidroxilamin-hidroklorid (1,04 g, 14,9 mmol) és nátrium-hidroxid $(596 \mathrm{mg}, 14,9 \mathrm{mmol})$ metanolos $(20 \mathrm{ml})$ oldatához csepegtettük, majd a reakcióelegyet 2 órán át szobahőmérsékleten kevertettük. Bepárlást követően $10 \mathrm{ml}$ vizet adtunk a nyers elegyhez, majd etil-acetáttal $(3 \times 30 \mathrm{ml})$ extraháltuk. Az egyesített szerves fázist $\mathrm{Na}_{2} \mathrm{SO}_{4}-$ on szárítottuk, majd bepároltuk. A nyers termékeket (272a-c) további tisztítás nélkül azonnal felhasználtuk a következő lépésben.

A nyers ketoximot $(\mathbf{2 7 2 a}-\mathbf{c})$ diklórmetánban $(30 \mathrm{ml})$ oldottuk, piridint $(1087 \mu 1,13,5 \mathrm{mmol})$ adtunk hozzá, majd $0{ }^{\circ} \mathrm{C}$-ra hütöttük. Ezt követően $p$-toluolszulfonil-klorid (2,84 g, 14,9 mmol) $20 \mathrm{ml}$ dilkórmetánban feloldott oldatát csepegtettük hozzá fél óra alatt. 6 óra szobahőmérsékleten történő kevertetés után a reakcióelegyet bepároltuk, vizet adtunk hozzá, majd kloroformmal (2 × $25 \mathrm{ml}$ ) extraháltuk. Az egyesített szerves fázist $\mathrm{Na}_{2} \mathrm{SO}_{4}$-on szárítottuk, bepároltuk, majd flashkromatográfiás tisztítást (RediSep Rf, szilikagél, EtOAc/hexán, 0:100-30:70 gradiens) követően a 273a-c ketoxim-tozilátokat izoláltuk.

A megfelelö 273a-c ketoxim-tozilátot $(9 \mathrm{mmol}) 20 \mathrm{ml}$ diklórmetánban feloldottuk és $0{ }^{\circ} \mathrm{C}$-on trietil-amint (1,38 ml, 9,9 mmol) csepegtettünk hozzá. A reakcióelegyet $0{ }^{\circ} \mathrm{C}$-on 30 percig, majd szobahőmérsékleten 1-6 órán át kevertettük. A 273c vegyület (270c $2 H$-azirin elöállítása) esetében 2 óra reakcióidő elteltével DBU-t (673 $\mu 1,4,5 \mathrm{mmol})$ adtunk a reakcióelegyhez és így folytattuk a kevertetést. A reakció lejátszódását követően híg sósavoldatot $(60 \mathrm{ml}, 0,05 \mathrm{M})$ adtunk a reakcióelegyhez, majd diklórmetánnal $(2 \times 25 \mathrm{ml})$ extraháltuk. Az egyesített szerves fázist $\mathrm{Na}_{2} \mathrm{SO}_{4}$-on szárítottuk, bepároltuk, végül vákuumdesztillációs eljárással tisztítottuk.

\section{Etil-3-metil-2H-azirin-2-karboxilát (( \pm -270a)}

A terméket a 4.1. általános szintézismódszer alapján állítottuk elö.

( \pm )-270a: 787 mg (22 \% összesített hozam (274a: 32\%, majd 270a: 69\%)); átlátszó folyadék; $\mathrm{R}_{\mathrm{f}}$ $=0,75($ hexán $/ \operatorname{EtOAc}=2 / 1)$.

terc-Butil-3-metil-2H-azirin-2-karboxilát (( \pm$)-270 b)$

A terméket a 4.1. általános szintézismódszer alapján állítottuk elö. 
( \pm )-270b: 912 mg (25\% összesített hozam (274b: 39\%, majd 270b: 65\%)); sárga folyadék; $\mathrm{R}_{\mathrm{f}}=$ $0,82($ hexán/EtOAc $=2 / 1)$.

Etil-2,3-dimetil-2H-azirin-2- karboxilát (( \pm -270c)

( \pm )-270c: 660 mg (23\% összesített hozam (274c: 44\%, majd 270c: 52\%)); átlátszó folyadék; $\mathrm{R}_{\mathrm{f}}$ $=0,64($ hexán $/ \operatorname{EtOAc}=2 / 1)$.

\subsection{Az etil-2-benzil-3-oxo-butirát (271d) előállítása}

A 271d vegyület szintézisét az irodalomban ismertetett módszer alapján végeztük. ${ }^{193}$

Kálium-terc-butoxid (4,31 g, 38,4 mmol) THF-ban (100 ml) készült szuszpenziójához $0{ }^{\circ} \mathrm{C}$-on etil-acetoacetátot (271a, 4,77 ml, 37,7 mmol) és terc-butanolt (335 $\mu \mathrm{L}, 3,5$ mmol) adtunk. A kapott tiszta oldatot 30 percig kevertettük, majd benzil-bromidot $(4,45 \mathrm{ml}, 37,4 \mathrm{mmol})$ csepegtettünk hozzá. A reakcióelegyet reflux hőmérsékleten 12 órán át kevertettük. Ezt követően vizet, majd telített $\mathrm{NaHCO}_{3}$ oldatot öntöttünk hozzá és dietil-éterrel $(2 \times 30 \mathrm{ml})$ extraháltuk. Az egyesített szerves fázisok bepárlását követően a 271d vegyületet oszlopkromatogáfiás tisztítással (pentán/dietil-éter $=19 / 1$, szilikagél) nyertük.

271d: 7,25 g (88\%); átlátszó olaj; $\mathrm{R}_{\mathrm{f}}=0,82$ (hexán/EtOAc = 3/1).

\subsection{Az ( \pm -etil-2-benzil-3-metil-2H-azirin-2-karboxilát (( \pm$)$-270d) előállítása}

A (土)-270d szintézisét szakirodalom alapján, ${ }^{188,189}$ módosított körülményekkel végeztük.

Hidroxilamin-hidroklorid $(537 \mathrm{mg}, 7,7 \mathrm{mmol})$ piridines $(7 \mathrm{ml})$ oldatához hozzáadtuk az etil-2benzil-3-oxo-butanoátot $(\mathbf{2 7 1 d}, 1,69 \mathrm{~g}, 7.7 \mathrm{mmol})$, majd a reakcióelegyet 4 órán át szobahőmérsékleten kevertettük. Ezután a reakcióelegyhez $0{ }^{\circ} \mathrm{C}$-on $p$-toluolszulfonil-kloridot (3,22g, 16,9 mmol) adtunk. 12 óra szobahőmérsékleten történő kevertetést követően a reakcióelegyhez vizes sósavoldatot $(40 \mathrm{ml}, 1 \mathrm{M})$ adtunk, majd diklórmetánnal $(2 \times 30 \mathrm{ml})$ extraháltuk. Az egyesített szerves fázist $\mathrm{Na}_{2} \mathrm{SO}_{4}$-on szárítottuk, bepároltuk, majd oszlopkromatográfiával (hexán/EtOAc = 12/1, szilikagél) tisztítottuk.

Az előző lépésben előállított 273d ketoxim-tozilátot (1,28 g, 3,3 mmol) vízmentes THF-ban (3,5 $\mathrm{ml}$ ) feloldottuk, $0{ }^{\circ} \mathrm{C}$-on, argon atmoszféra alatt DBU-t (748 $\mu 1,5 \mathrm{mmol}$ ) csepegtettünk hozzá, majd a reakcióelegyet hagytuk szobahőmérsékletre felmelegedni. Egy óra kevertetést, majd bepárlást követően a $( \pm)$-270d $2 H$-azirint oszlopkromatográfiás tisztítással (hexán/EtOAc $=6 / 1$, szilikagél) nyertük.

(土)-270d: 558 mg (40\% összesített hozam (274d: 51\%, majd 270d: 78\%)); átlátszó folyadék; $\mathrm{R}_{\mathrm{f}}$ $=0,70($ hexán $/$ EtOAc $=2 / 1)$. 


\section{4. $\quad \mathrm{A}( \pm)-270 \mathrm{e}-\mathrm{i}$ 2-fenil-2H-azirinek előállításának általános leírása}

A ( \pm -270e-i vegyületek szintézisét az irodalomban ismertetett módszer alapján, ${ }^{190}$ módosított körülményekkel végeztük.

Hidroxilamin-hidrokloridot (452 mg, 6,5 mmol), piridint (524 $\mu 1,6,5 \mathrm{mmol})$ és a megfelelö 274a-e ketont (5 mmol) etanolban $(25 \mathrm{ml})$ szuszpendáltuk, majd szobahőmérsékleten kevertettük. A reakció lejátszódását követően a reakcióelegyet bepároltuk, vizes sósavoldatot (15 ml, $1 \mathrm{M})$ adtunk hozzá, majd etil-acetáttal extraháltuk $(3 \times 15 \mathrm{ml})$. Az egyesített szerves fázist $\mathrm{Na}_{2} \mathrm{SO}_{4}$-on szárítottuk, majd bepároltuk. A nyers termékeket (275a-e) további tisztítás nélkül használtuk fel a következő lépésben.

A 275a-e nyers oxim vízmentes THF-os oldatához $(20 \mathrm{ml}) 0{ }^{\circ} \mathrm{C}$-on trietil-amint $(1,05 \mathrm{ml}, 7,5$ mmol) és metánszulfonil-kloridot ( $580 \mu 1,7,5 \mathrm{mmol})$ adtunk, majd 30 percig kevertettük. Ezután a reakcióelegyhez 10 perc alatt DBU-t $(1,12 \mathrm{ml}, 7,5 \mathrm{mmol})$ csepegtettünk. Újabb 30 perc kevertetést követően az elegyet szilikagél rétegen átengedtük, etil-acetáttal eluáltuk, az eluátumot bepároltuk, végül szilikagélen flash-kromatográfiás eljárással tisztítottuk (RediSep Rf, szilikagél, EtOAc/hexán, 0:100-25:75 gradiens).

\section{2,3-Difenil-2H-azirin (( \pm$)-270 \mathrm{e})$}

A terméket a 4.4. általános szintézismódszer alapján állítottuk elő.

$\left( \pm\right.$ )-270e: 568 mg (59\%); fehér, szilárd; $\mathrm{R}_{\mathrm{f}}=0,84$ (hexán/EtOAc $\left.=20 / 1\right)$.

\section{3-Benzil-2-fenil-2H-azirin (( \pm$)-270 f)$}

A terméket a 4.4. általános szintézismódszer alapján állítottuk elő.

( \pm )-270f: $371 \mathrm{mg}\left(36 \%\right.$ ); sárga, olaj; $\mathrm{R}_{\mathrm{f}}=0,87$ (hexán/EtOAc $=2 / 1$ ).

\section{3-(4-Metoxifenil)-2-fenil-2H-azirin $(( \pm)-270 g)$}

A terméket a 4.4. általános szintézismódszer alapján állítottuk elö.

( \pm )-270g: 773 mg (69\%); sárga, olaj; $\mathrm{R}_{\mathrm{f}}=0,66$ (hexán/EtOAc = 15/1).

\section{3-(4-Fluorfenil)-2-fenil-2H-azirin (( \pm )-270h)}

A terméket a 4.4. általános szintézismódszer alapján állítottuk elő.

( \pm )-270h: 644 mg (61\%); sárga, olaj; $\mathrm{R}_{\mathrm{f}}=0,88$ (hexán/EtOAc = 15/1).

\section{3-(4-Klórfenil)-2-fenil-2H-azirin (( \pm )-270i)}

A terméket a 4.4. általános szintézismódszer alapján állítottuk elő.

( \pm )-270i: 798 mg (70 \%); sárga, olaj; $\mathrm{R}_{\mathrm{f}}=0,91$ (hexán/EtOAc $=15 / 1$ ). 


\subsection{A ( \pm$)$-3-fenil-2H-azirin $(( \pm)-270 j)$ előállítása}

Az ( \pm -270j vegyület szintézisét az irodalomban ismertetett módszer alapján végeztük. ${ }^{191}$

Sztirol (276, 1,3 g, 12,5 mmol) szén-tetrakloridos $(10 \mathrm{ml})$ oldatához $0{ }^{\circ} \mathrm{C}$-on szén-tetrakloridban (4 ml) oldott brómot (2 g, 12,5 mmol) csepegtettünk, majd a reakcióelegyet hagytuk szobahőmérsékletre melegedni. A sztirol teljes konverzióját követően ( 90 perc) az oldószert lepároltuk, a nyers elegyet DMSO-ban $(20 \mathrm{ml})$ feloldottuk és egy háromnyakú gömblombikba helyeztük, majd argon áram alatt, jeges hütés mellett 45 perc alatt nátrium-azidot $(1,23 \mathrm{~g}, 18,8$ mmol) adagoltunk hozzá. 13 óra szobahőmérsékleten történő kevertetés után $0{ }^{\circ} \mathrm{C}$-ra visszahütve a reakcióelegyhez vizes $\mathrm{NaOH}$ oldatot $(0,5 \mathrm{~g}, 12,5 \mathrm{mmol} \mathrm{NaOH} 0,5 \mathrm{ml}$ vízben oldva) csepegtettünk, majd további 24 óráig szobahőmérsékleten kevertettük. Ezt követően a reakcióelegyet vizes $\mathrm{NaHCO}_{3}$ oldatra $(2 \%, 50 \mathrm{ml})$ öntöttük és diklórmetánnal $(3 \times 25 \mathrm{ml})$ extraháltuk. Az egyesített szerves fázist vízzel mostuk, majd $\mathrm{Na}_{2} \mathrm{SO}_{4}$-on történő szárítást követően bepároltuk. Az így kapott nyers 1-azidosztirolhoz (278, vörös színű olaj) hexánt (5 ml) öntöttünk, alumínium-oxid (5 g) oszlopon átengedtük, hexánnal (20 ml) eluáltuk. Az eluátum bepárlásával kapott halványsárga olajat $30 \mathrm{ml}$ toluolban feloldottuk és 1,5 órán keresztül forraltuk. Az oldószer bepárlása után a nyers reakcióelegyet vákuumdesztillációs eljárással tisztítottuk.

( \pm )-270j: 920 mg (63\%); átlátszó folyadék; $\mathrm{R}_{\mathrm{f}}=0,81$ (hexán/EtOAc $\left.=19 / 1\right)$.

\subsection{Az (-)-(R)-etil-3-metil-2H-azirin-2-karboxilát ((-)-(R)-270a) előállítása}

A (-)-(R)-270a vegyület szintézisét az irodalomban ismertetett módszer alapján végeztük. ${ }^{192}$

Kinidin $\left(868 \mathrm{mg}, 1 \mathrm{ekv}\right.$.) vízmentes toluolos oldatához $(360 \mathrm{ml}) 0{ }^{\circ} \mathrm{C}$-on a 273a ketoxim-tozilát (800 mg, 2,68 mmol, 4.1. szintézismódszer alapján készült) vízmentes toluolos oldatát (40 ml) csepegtettük. Az elegyet argon atmoszféra alatt, $0{ }^{\circ} \mathrm{C}$-on 24 órát kevertettük, majd híg vizes sósavoldatot $(200 \mathrm{ml}, 0,05 \mathrm{M})$ adtunk hozzá és dietil-éterrel $(3 \times 100 \mathrm{ml})$ extraháltuk. Az egyesített szerves fázist $\mathrm{Na}_{2} \mathrm{SO}_{4}$-on szárítottuk, bepároltuk, majd a kapott nyersterméket vákuumdesztillációs eljárással tisztítottuk.

(-)-(R)-270a: $60 \mathrm{mg}(18 \%) ; 72 \%$ ee; átlátszó folyadék; $\mathrm{R}_{\mathrm{f}}=0,75($ hexán/EtOAc $=2 / 1)$. 


\subsection{A 281 és $282 N$-acilaziridinek általános előállítása}

A megfelelő $2 H$-azirin $(( \pm)-\mathbf{2 7 0 a}-\mathbf{f}, 0,5 \mathrm{mmol})$ vízmentes THF-os $(4 \mathrm{ml})$ oldatához a megfelelő izocianidot (279a-g, 0,55 mmol), karbonsavat (280a-p, 0,55 mmol) és végül vízmentes $\mathrm{ZnCl}_{2}-$ ot (17 mg, $25 \mathrm{~mol} \%)$ adtunk. A reakcióelegyet $55{ }^{\circ} \mathrm{C}$-on, argon atmoszféra alatt 4-6 órán keresztül, az azirin teljes konverziójáig kevertettük. Bepárlást követően a nyersterméket oszlopkromatográfiával tisztítottuk (szilikagél, eluens: hexán/EtOAc, gradiens elúció).

( \pm )-Etil-transz-1-benzoil-3-(terc-butilkarbamoil)-3-metilaziridin-2-karboxilát $(( \pm)-281\{1\})$

A terméket a 4.7. általános szintézismódszer alapján állítottuk elő.

( \pm )-281\{1\}: 115 mg (69\%); fehér, szilárd; Op. $102-103{ }^{\circ} \mathrm{C} ; \mathrm{R}_{f}=0,46$ (hexán/EtOAc = 2/1).

$(2 R, 3 R)$-Etil-1-benzoil-3-(terc-butilkarbamoil)-3-metilaziridin-2-karboxilát $\quad((2 R, 3 R)-$ 281\{1\})

A terméket a 4.7. általános szintézismódszer alapján állítottuk elő.

(2R,3R)-281\{1\}: $113 \mathrm{mg}$ (68 \%); fehér, szilárd; 72\% ee. $0{ }^{\circ} \mathrm{C}$-on dietil-éterből történő átkristályosítás után: $58 \mathrm{mg}$ (35\%); fehér, szilárd; $92 \%$ ee; $[\alpha]^{23}+27,1^{\circ}\left(\mathrm{c} 0,7 ; \mathrm{CHCl}_{3}\right)$.

( \pm -Etil-cisz-1-benzoil-3-(terc-butilkarbamoil)-3-metilaziridin-2-karboxilát $(( \pm)-282\{1\})$

A terméket a 4.7. általános szintézismódszer alapján állítottuk elő.

( \pm )-282 $\{1\}: 7 \mathrm{mg}$ (4\%); fehér, szilárd; Op. 87-88 ${ }^{\circ} \mathrm{C} ; \mathrm{R}_{f}=0,67$ (hexán/EtOAc $\left.=2 / 1\right)$.

( \pm )-Etil-transz-3-(terc-butilkarbamoil)-1-(3-metoxibenzoil)-3-metilaziridin-2-karboxilát $(( \pm)-281\{2\})$

A terméket a 4.7. általános szintézismódszer alapján állítottuk elő.

( \pm )-281 $\{2\}: 144$ mg (79 \%); fehér, szilárd; Op. 100-102 ${ }^{\circ} \mathrm{C} ; \mathrm{R}_{f}=0,38$ (hexán/EtOAc = 2/1).

( \pm )-Etil-transz-3-(terc-butilkarbamoil)-1-(4-hidroxibenzoil)-3-metilaziridin-2-karboxilát $(( \pm)-281\{3\})$

A terméket a 4.7. általános szintézismódszer alapján állítottuk elő.

( \pm )-281 $\{3\}$ : $98 \mathrm{mg}$ (56 \%); fehér, szilárd; Op. $185-187^{\circ} \mathrm{C} ; \mathrm{R}_{f}=0,12($ hexán/EtOAc $=2 / 1)$.

( \pm )-Etil-transz-3-(terc-butilkarbamoil)-1-(2-klórbenzoil)-3-metilaziridin-2-karboxilát $(( \pm)$ 281\{4\})

A terméket a 4.7. általános szintézismódszer alapján állítottuk elő.

$( \pm)-281\{4\}: 103$ mg (61\%); fehér, szilárd; Op. 102-103 ${ }^{\circ} \mathrm{C} ; \mathrm{R}_{f}=0,50$ (hexán/EtOAc = 2/1). 
( \pm )-Etil-transz-3-(terc-butilkarbamoil)-3-metil-1-(2-fenilacetil)-aziridin-2-karboxilát $\quad(( \pm)$ $281\{5\})$

A terméket a 4.7. általános szintézismódszer alapján állítottuk elő.

( \pm )-281 \{5\}: 119 mg (69 \%); fehér, szilárd; Op. $107-108^{\circ} \mathrm{C} ; \mathrm{R}_{f}=0,44$ (hexán/EtOAc = 2/1).

( \pm )-Etil-transz-3-(terc-butilkarbamoil)-3-metil-1-((E)-3-(3,4,5-trimetoxifenil)-akriloil)aziridin-2-karboxilát $(( \pm)-281\{6\})$

A terméket a 4.7. általános szintézismódszer alapján állítottuk elő.

( \pm )-281 \{6\}: 135 mg (60\%); fehér, szilárd; Op. $131-132{ }^{\circ} \mathrm{C} ; \mathrm{R}_{f}=0,41$ (hexán/EtOAc = 2/1).

( \pm )-Etil-transz-3-(terc-butilkarbamoil)-3-metil-1-nikotinoil-aziridin-2-karboxilát $\quad(( \pm)-$ 281\{7\})

A terméket a 4.7. általános szintézismódszer alapján állítottuk elő.

( \pm )-281 $\{7\}$ : 47 mg (28 \%); fehér, szilárd; Op. $114-116^{\circ} \mathrm{C} ; \mathrm{R}_{f}=0,29$ (hexán/EtOAc = 1/2).

( \pm )-Etil-transz-1-acetil-3-(terc-butilkarbamoil)-3-metilaziridin-2-karboxilát (( \pm )-281\{8\})

A terméket a 4.7. általános szintézismódszer alapján állítottuk elő.

( \pm )-281 \{8\}: 102 mg (75\%); fehér, szilárd; Op. 101-102 ${ }^{\circ} \mathrm{C} ; \mathrm{R}_{f}=0,31$ (hexán/EtOAc = 2/1).

( \pm )-Etil-transz-3-(terc-butilkarbamoil)-1-(2-klóracetil)-3-metilaziridin-2-karboxilát $\quad(( \pm)$ $281\{9\})$

A terméket a 4.7. általános szintézismódszer alapján állítottuk elő.

( \pm )-281 $\{9\}: 84$ mg (55 \%); fehér, szilárd; Op. 93-94 ${ }^{\circ} \mathrm{C} ; \mathrm{R}_{f}=0,51$ (hexán/EtOAc = 2/1).

( \pm )-Etil-transz-3-(terc-butilkarbamoil)-3-metil-1-(2,2,2-trifluoracetil)-aziridin-2-karboxilát $(( \pm)-281\{10\})$

A terméket a 4.7. általános szintézismódszer alapján állítottuk elő.

( \pm )-281 $\{10\}: 87$ mg (54 \%); fehér, szilárd; Op. $94-95^{\circ} \mathrm{C} ; \mathrm{R}_{f}=0,53$ (hexán/EtOAc $=2 / 1$ ).

( \pm )-Etil-transz-1-benzoil-3-metil-3-((2,4,4-trimetilpentán-2-il)-karbamoil)-aziridin-2karboxilát (( \pm$)-281\{11\})$

A terméket a 4.7. általános szintézismódszer alapján állítottuk elö.

( \pm )-281 $\{11\}: 151 \mathrm{mg}$ (78 \%); fehér, szilárd; Op. 83-84 ${ }^{\circ} \mathrm{C} ; \mathrm{R}_{f}=0,61($ hexán/EtOAc $=2 / 1)$.

( \pm )-Etil-transz-1-benzoil-3-(ciklohexilkarbamoil)-3-metilaziridin-2-karboxilát

$(( \pm)-$ 281\{12\})

A terméket a 4.7. általános szintézismódszer alapján állítottuk elö.

( \pm )-281 $\{12\}$ : 127 mg (71\%); fehér, szilárd; Op. 166-167 ${ }^{\circ} \mathrm{C} ; \mathrm{R}_{f}=0,617$ (hexán/EtOAc = 1/1). 
( \pm )-Etil-transz-1-benzoil-3-(benzilkarbamoil)-3-metilaziridin-2-karboxilát $(( \pm)-281\{13\})$

A terméket a 4.7. általános szintézismódszer alapján állítottuk elö.

( \pm )-281 $\{13\}$ : 106 mg (58 \%); fehér, szilárd; Op. $121-123{ }^{\circ} \mathrm{C} ; \mathrm{R}_{f}=0,59$ (hexán/EtOAc = 1/1).

( \pm )-Etil-transz-1-benzoil-3-metil-3-((3,4,5-trimetoxifenil)-karbamoil)-aziridin-2-karboxilát $(( \pm)-281\{14\})$

A terméket a 4.7. általános szintézismódszer alapján állítottuk elő.

( \pm )-281 \{14\}: $84 \mathrm{mg}(38 \%)$; fehér, szilárd; Op. $140-141{ }^{\circ} \mathrm{C} ; \mathrm{R}_{f}=0,36$ (hexán/EtOAc = 1/1).

( \pm )-Etil-transz-1-benzoil-3-metil-3-((4-nitrofenil)-karbamoil)-aziridin-2-karboxilát $\quad(( \pm)$ 281 $\{15\})$

A terméket a 4.7. általános szintézismódszer alapján állítottuk elő.

( \pm )-281\{15\}: $120 \mathrm{mg}(60 \%)$; sárga, szilárd; Op. $141-143{ }^{\circ} \mathrm{C} ; \mathrm{R}_{f}=0,66$ (hexán/EtOAc = 1/1).

( \pm )-Etil-transz-3-metil-1-(2-fenilacetil)-3-((2,4,4-trimetilpentán-2-il)-karbamoil)-aziridin2-karboxilát (( \pm -281\{16\})

A terméket a 4.7. általános szintézismódszer alapján állítottuk elő.

( \pm )-281 \{16\}: 149 mg (77\%); fehér, szilárd; Op. 95-96 ${ }^{\circ} \mathrm{C} ; \mathrm{R}_{f}=0,59($ hexán/EtOAc $=2 / 1)$.

( \pm )-Etil-transz-3-metil-3-(pentilkarbamoil)-1-(2-fenilacetil)-aziridin-2-karboxilát $\quad(( \pm)$ 281\{17\})

A terméket a 4.7. általános szintézismódszer alapján állítottuk elő.

( \pm )-281 \{17\}: $142 \mathrm{mg}$ (79\%); fehér, szilárd; Op. 90-91 ${ }^{\circ} \mathrm{C} ; \mathrm{R}_{f}=0,30$ (hexán/EtOAc = 2/1).

( \pm )-Etil-transz-1-acetil-3-(ciklohexilkarbamoil)-3-metilaziridin-2-karboxilát $(( \pm)-281\{18\})$

A terméket a 4.7. általános szintézismódszer alapján állítottuk elő.

( \pm )-281 $\{18\}: 101 \mathrm{mg}\left(68 \%\right.$ ); fehér, szilárd; Op. $97-98^{\circ} \mathrm{C} ; \mathrm{R}_{f}=0,55($ hexán/EtOAc $=1 / 1)$.

( \pm )-Etil-transz-3-(ciklohexilkarbamoil)-3-metil-1-(2-fenilacetil)-paziridin-2-karboxilát (( \pm )281\{19\})

A terméket a 4.7. általános szintézismódszer alapján állítottuk elő.

( \pm )-281 $\{19\}: 112 \mathrm{mg}(60 \%)$; fehér, szilárd; Op. $101-102{ }^{\circ} \mathrm{C} ; \mathrm{R}_{f}=0,35$ (hexán/EtOAc = 2/1).

( \pm )-Etil-transz-3-(ciklohexilkarbamoil)-3-metil-1-(2,4,6-trimetilbenzoil)-aziridin-2karboxilát (( \pm$)-281\{20\})$

A terméket a 4.7. általános szintézismódszer alapján állítottuk elő.

( \pm )-281 $\{20\}: 160 \mathrm{mg}(80 \%)$; fehér, szilárd; Op. $143-144{ }^{\circ} \mathrm{C} ; \mathrm{R}_{f}=0,61$ (hexán/EtOAc = 2/1). 
( \pm )-Etil-transz-3-(ciklohexilkarbamoil)-1-(3-fluorbenzoil)-3-metilaziridin-2-karboxilát

$(( \pm)-281\{21\})$

A terméket a 4.7. általános szintézismódszer alapján állítottuk elő.

( \pm )-281 $\{21\}: 145 \mathrm{mg}\left(77 \%\right.$ ); fehér, szilárd; Op. $165-167^{\circ} \mathrm{C} ; \mathrm{R}_{f}=0,39$ (hexán/EtOAc = 2/1).

( \pm )-Etil-transz-3-(benzilkarbamoil)-3-metil-1-(2-fenilacetil)-aziridin-2-karboxilát $\quad(( \pm)-$ 281\{22\})

A terméket a 4.7. általános szintézismódszer alapján állítottuk elő.

( \pm )-281 $\{22\}: 127 \mathrm{mg}$ (67\%); fehér, szilárd; Op. $123-125^{\circ} \mathrm{C} ; \mathrm{R}_{f}=0,25$ (hexán/EtOAc = 2/1).

( \pm )-Etil-transz-3-(benzilkarbamoil)-1-(3-metoxibenzoil)-3-metilaziridin-2-karboxilát $\quad(( \pm)-$ $281\{23\})$

A terméket a 4.7. általános szintézismódszer alapján állítottuk elő.

( \pm )-281 $\{23\}$ : 104 mg (58 \%); fehér, szilárd; Op. $78-79{ }^{\circ} \mathrm{C} ; \mathrm{R}_{f}=0,59$ (hexán/EtOAc $\left.=1 / 1\right)$.

( \pm )-Etil-transz-1-acetil-3-metil-3-((3,4,5-trimetoxifenil)-karbamoil)-aziridin-2-karboxilát $(( \pm)-281\{24\})$

A terméket a 4.7. általános szintézismódszer alapján állítottuk elö.

( \pm )-281 $\{24\}: 27$ mg (22\%); fehér, szilárd; Op. 140-142 ${ }^{\circ} \mathrm{C} ; \mathrm{R}_{f}=0,41$ (hexán/EtOAc = 1/2).

( \pm )-Etil-transz-3-metil-1-(2-fenilacetil)-3-((3,4,5-trimetoxifenil)-karbamoil)-aziridin-2karboxilát (( \pm$)-281\{25\})$

A terméket a 4.7. általános szintézismódszer alapján állítottuk elö.

( \pm )-281 $\{25\}: 81 \mathrm{mg}(36 \%)$; színtelen, olaj; $\mathrm{R}_{f}=0,40$ (hexán/EtOAc $\left.=1 / 1\right)$.

( \pm )-Etil-transz-3-metil-1-(4-(trifluormetil)-benzoil)-3-((3,4,5-trimetoxifenil)-karbamoil)aziridin-2-karboxilát $(( \pm)-281\{26\})$

A terméket a 4.7. általános szintézismódszer alapján állítottuk elő.

( \pm )-281 \{26\}: 74 mg (29\%); fehér, szilárd; Op. $149-150{ }^{\circ} \mathrm{C} ; \mathrm{R}_{f}=0,44$ (hexán/EtOAc = 1/1).

( \pm )-Etil-transz-1-(2-klóracetil)-2,3-dimetil-3-((4-nitrofenil)-karbamoil)-aziridin-2karboxilát (( \pm$)-281\{27\})$

A terméket a 4.7. általános szintézismódszer alapján állítottuk elő.

( \pm )-281 $\{27\}$ : 104 mg (56 \%); halványsárga, szilárd; Op. $148-151{ }^{\circ} \mathrm{C} ; \mathrm{R}_{f}=0,28$ (hexán/EtOAc $=$ 2/1). 
(土)-Etil transz-1-(3-fluorbenzoil)-3-metil-3-((4-nitrofenil)-karbamoil)-aziridin-2-karboxilát $(( \pm)-281\{28\})$

A terméket a 4.7. általános szintézismódszer alapján állítottuk elő.

(土)-281 \{28\}: 59 mg (28 \%); halványsárga, szilárd; Op. $145-146{ }^{\circ} \mathrm{C} ; \mathrm{R}_{f}=0,29$ (hexán/EtOAc $=$ $2 / 1)$.

( \pm )-terc-Butil-transz-1-benzoil-3-(terc-butilkarbamoil)-3-metilaziridin-2-karboxilát $\quad(( \pm)-$ 281\{29\})

A terméket a 4.7. általános szintézismódszer alapján állítottuk elő.

( \pm )-281 $\{29\}: 110 \mathrm{mg}(61 \%)$; fehér, szilárd; Op. $167-168^{\circ} \mathrm{C} ; \mathrm{R}_{f}=0,75$ (hexán/EtOAc = 2/1).

( \pm )-terc-Butil-transz-1-acetil-3-(ciklohexilkarbamoil)-3-metilaziridin-2-karboxilát $\quad(( \pm)-$ 281\{30\})

A terméket a 4.7. általános szintézismódszer alapján állítottuk elő.

( \pm )-281 $\{30\}: 87 \mathrm{mg}(54 \%)$; fehér, szilárd; Op. $108-109^{\circ} \mathrm{C} ; \mathrm{R}_{f}=0,44$ (hexán/EtOAc = 2/1).

( \pm )-terc-Butil-transz-1-benzoil-3-(benzilkarbamoil)-3-metilaziridin-2-karboxilát

$(( \pm)-$ 281\{31\})

A terméket a 4.7. általános szintézismódszer alapján állítottuk elő.

( \pm )-281 $\{31\}$ : 42 mg (22\%); fehér, szilárd; Op. $153-154{ }^{\circ} \mathrm{C} ; \mathrm{R}_{f}=0,54$ (hexán/EtOAc = 2/1).

( \pm )-terc-Butil-transz-3-metil-3-((3,4,5-trimetoxifenil)-karbamoil)-1-(2,4,6-trimetilbenzoil)aziridin-2-karboxilát $(( \pm)-281\{32\})$

A terméket a 4.7. általános szintézismódszer alapján állítottuk elő.

( \pm )-281 $\{32\}: 52$ mg (20\%); fehér, szilárd; Op. 94-95 ${ }^{\circ} \mathrm{C} ; \mathrm{R}_{f}=0,42($ hexán/EtOAc = 2/1).

( \pm )-Etil-transz-1-benzoil-3-(terc-butilkarbamoil)-2,3-dimetilaziridin-2-karboxilát és $( \pm)$ etil-cisz-1-benzoil-3-(terc-butilkarbamoil)-2,3-dimetilaziridin-2-karboxilát $\quad(( \pm)-281\{33\}+$ $( \pm)-282\{33\})$

A diasztereomer keveréket a 4.7. általános szintézismódszer alapján állítottuk elő.

$( \pm)-\mathbf{2 8 1}\{33\}+( \pm)-\mathbf{2 8 2}\{33\}: 95 \mathrm{mg}(55 \%)$; sárga, olaj; $\mathrm{R}_{f}=0,51$ (hexán/EtOAc $\left.=2 / 1\right)$.

( \pm )-Etil-transz-1-benzoil-3-(ciklohexilkarbamoil)-2,3-dimetilaziridin-2-karboxilát $\quad(( \pm)-$ 281\{34\})

A terméket a 4.7. általános szintézismódszer alapján állítottuk elö.

( \pm )-281 $\{34\}$ : $58 \mathrm{mg}$ (31\%); fehér, szilárd; Op. 99-100 ${ }^{\circ} \mathrm{C} ; \mathrm{R}_{f}=0,40$ (hexán/EtOAc $=2 / 1$ ). 
(土)-Etil-transz-3-(benzilkarbamoil)-1-(3-metoxibenzoil)-2,3-dimetilaziridin-2-karboxilát és ( \pm )-etil-cisz-3-(benzilkarbamoil)-1-(3-metoxibenzoil)-2,3-dimetilaziridin-2-karboxilát $(( \pm)$ $281\{35\}+( \pm)-282\{35\})$

A diasztereomer keveréket a 4.7. általános szintézismódszer alapján állítottuk elő.

$( \pm)-\mathbf{2 8 1}\{35\}+( \pm)-\mathbf{2 8 2}\{35\}: 84 \mathrm{mg}(41 \%)$; sárga, olaj; $\mathrm{R}_{f}=0,22$ és $\mathrm{R}_{f}=0,31$ (semleges alumínium-oxid, hexán/EtOAc = 20/1).

( \pm )-Etil-transz-1-benzoil-2-benzil-3-(terc-butilkarbamoil)-3-metilaziridin-2-karboxilát $(( \pm)$ 281\{36\})

A terméket a 4.7. általános szintézismódszer alapján állítottuk elő.

( \pm )-281 $\{36\}: 36$ mg (17\%); színtelen, olaj; $\mathrm{R}_{f}=0,66($ hexán/EtOAc = 2/1).

( \pm )-Etil-cisz-1-benzoil-2-benzil-3-(terc-butilkarbamoil)-3-metilaziridin-2-karboxilát $\quad(( \pm)$ 282 $\{36\})$

A terméket a 4.7. általános szintézismódszer alapján állítottuk elő.

( \pm )-282\{36\}: 49 mg (23\%); színtelen, olaj; $\mathrm{R}_{f}=0,71$ (hexán/EtOAc = 2/1).

( \pm )-transz-1-Benzoil- $N$-(terc-butil)-2,3-difenilaziridin-2-karboxamid (( \pm )-281\{37\})

A terméket a 4.7. általános szintézismódszer alapján állítottuk elő.

( \pm )-281 \{37\}: $139 \mathrm{mg}$ (70\%); fehér, szilárd; Op. $126-127^{\circ} \mathrm{C} ; \mathrm{R}_{f}=0,90$ (hexán/EtOAc = 2/1).

( \pm )-transz-1-Acetil- $N$-(terc-butil)-2,3-difenilaziridin-2-karboxamid (( \pm )-281\{38\})

A terméket a 4.7. általános szintézismódszer alapján állítottuk elő.

( \pm )-281 $\{38\}: 102 \mathrm{mg}(61 \%)$; fehér, szilárd; Op. $116-117^{\circ} \mathrm{C} ; \mathrm{R}_{f}=0,77$ (hexán/EtOAc = 3/1).

( \pm )-transz- $N$-Ciklohexil-2,3-difenil-1-(2,4,6-trimetilbenzoil)-aziridin-2-karboxamid $\quad(( \pm)$ 281\{39\})

A terméket a 4.7. általános szintézismódszer alapján állítottuk elő.

( \pm )-281 \{39\}: 65 mg (28\%); fehér, szilárd; Op. 135-136 ${ }^{\circ} \mathrm{C} ; \mathrm{R}_{f}=0,94$ (hexán/EtOAc = 2/1).

( \pm )-transz-2,3-Difenil-1-(2-fenilacetil)- $N$-(3,4,5-trimetoxifenil)-aziridin-2-karboxamid $(( \pm)$ 281\{40\})

A terméket a 4.7. általános szintézismódszer alapján állítottuk elő.

( \pm )-281 $\{40\}: 114 \mathrm{mg}$ (43\%); fehér, szilárd; Op. $144-146{ }^{\circ} \mathrm{C} ; \mathrm{R}_{f}=0,36$ (hexán/EtOAc = 2/1).

( \pm )-transz-1-Benzoil-2-benzil- $N$-(terc-butil)-3-fenilaziridin-2-karboxamid (( \pm )-281\{41\})

A terméket a 4.7. általános szintézismódszer alapján állítottuk elő.

( \pm )-281 $\{41\}: 138 \mathrm{mg}\left(67 \%\right.$ ); fehér, szilárd; Op. $146-147^{\circ} \mathrm{C} ; \mathrm{R}_{f}=0,82$ (hexán/EtOAc = 3/1). 
( \pm )-transz-1-Acetil-2-benzil- $N$-(terc-butil)-3-fenilaziridin-2-karboxamid (( \pm )-281\{42\})

A terméket a 4.7. általános szintézismódszer alapján állítottuk elő.

( \pm )-281 $\{42\}$ : 109 mg (62 \%); fehér, szilárd; Op. $151-152{ }^{\circ} \mathrm{C} ; \mathrm{R}_{f}=0,57$ (hexán/EtOAc = 2/1).

( \pm )-transz-2-Benzil- $N$-ciklohexil-3-fenil-1-(2,4,6-trimetilbenzoil)-aziridin-2-karboxamid $(( \pm)-281\{43\})$

A terméket a 4.7. általános szintézismódszer alapján állítottuk elő.

( \pm )-281 \{43\}: 96 mg (40\%); fehér, szilárd; Op. $132-133{ }^{\circ} \mathrm{C} ; \mathrm{R}_{f}=0,75$ (hexán/EtOAc = 2/1).

( \pm )-transz-2-Benzil-3-fenil-1-(2-fenilacetil)- $N$-(3,4,5-trimetoxifenil)-aziridin-2-karboxamid $(( \pm)-281\{44\})$

A terméket a 4.7. általános szintézismódszer alapján állítottuk elő.

( \pm )-281 \{44\}: $136 \mathrm{mg}$ (51\%); sárga, szilárd; Op. $68-69^{\circ} \mathrm{C} ; \mathrm{R}_{f}=0,73$ (hexán/EtOAc = 1/1).

Etil-(2S,3S)-1-((S)-5-(terc-butoxi)-4-((terc-butoxikarbonil)-amino)-5-oxopentanoil)-3-(tercbutilkarbamoil)-3-metilaziridin-2-karboxilát és etil-(2R, 3R)-1-((S)-5-(terc-butoxi)-4-((tercbutoxikarbonil)-amino)-5-oxopentanoil)-3-(terc-butilkarbamoil)-3-metilaziridin-2karboxilát (281\{45\})

A diasztereomer keveréket a 4.7. általános szintézismódszer alapján állítottuk elö. $\mathbf{2 8 1}\{45\}: 211 \mathrm{mg}\left(82 \%\right.$ ); sárga, szilárd; $\mathrm{R}_{f}=0,35$ (hexán/EtOAc = 2/1).

(2S,3S)-Etil-transz-1-(3-((terc-butoxikarbonil)-amino)-propanoil)-3-(terc-butilkarbamoil)3-metilaziridin-2-karboxilát és $\quad(2 R, 3 R)$-etil-transz-1-(3-((terc-butoxikarbonil)-amino)propanoil)-3-(terc-butilkarbamoil)-3-metilaziridin-2-karboxilát (281\{46\})

A diasztereomer keveréket a 4.7. általános szintézismódszer alapján állítottuk elő. $281\{46\}: 287$ mg (70\%); sárga, szilárd; $\mathrm{R}_{f}=0,57$ és $\mathrm{R}_{f}=0,66($ hexán/EtOAc $=1 / 1)$.

( \pm )-Etil-transz-1-(3-((terc-butoxikarbonil)-amino)-propanoil)-3-(terc-butilkarbamoil)-3metilaziridin-2-karboxilát (( \pm$)$-281\{47\})

A terméket a 4.7. általános szintézismódszer alapján állítottuk elő.

$( \pm)-281\{47\}: 150$ mg (75\%); fehér, szilárd; Op. 99-101 ${ }^{\circ} \mathrm{C} ; \mathrm{R}_{f}=0,57$ (hexán/EtOAc $=1 / 1$ ).

Etil-(2S,3S)-1-((R)-2-((terc-butoxikarbonil)-amino)-2-fenilacetil)-3-(terc-butilkarbamoil)3-metilaziridin-2-karboxilát és etil-(2R,3R)-1-((R)-2-((terc-butoxikarbonil)-amino)-2fenilacetil)-3-(terc-butilkarbamoil)-3-metilaziridin-2-karboxilát (281\{48\})

A diasztereomer keveréket a 4.7. általános szintézismódszer alapján állítottuk elő. 281\{48\}: 148 mg (64\%); sárga, olaj; $\mathrm{R}_{f}=0,81$ (hexán/EtOAc = 1/1). 


\subsection{A ( \pm -287-292 $N$-acilaziridin-2,3-dikarboxamidok általános előállítása}

A megfelelő $( \pm)$-281 $\{1,11,12\}$ aziridin-észter $(0,3 \mathrm{mmol})$ THF-es $(1,5 \mathrm{ml})$ oldatához jeges hütés mellett 1 M-os nátrium-hidroxid $(350 \mu 1,0,35 \mathrm{mmol})$ oldatot csepegtettünk, majd a reakcióelegyet szobahőmérsékleten 12 órán keresztül kevertettük. Az észterhidrolízis lejátszódását követően a reakcióelegyet bepároltunk, DMF-ban $(6 \mathrm{ml})$ oldottuk, majd $N$-etil- $N^{\prime}-$ (3-dimetilaminopropil)-karbodiimid-hidrokloridot (67 mg, 0,35 mmol), 1-hidroxibenztriazolt (55 mg, 0,41 mmol) és megfelelő 286a-d amint $(0,3 \mathrm{mmol})$ adtunk hozzá. 12 óra szobahőmérsékleten történő kevertetést követően a reakcióelegyhez vizet (20 ml) adtunk és etilacetáttal $(2 \times 10 \mathrm{ml})$ extraháltuk. Az egyesített szerves fázist $\mathrm{Na}_{2} \mathrm{SO}_{4}$-on szárítottuk, bepároltuk, majd oszlopkromatográfiával (szilikagél, eluens: hexán/EtOAc, gradiens elúció) tisztítottuk.

( \pm )-transz-1-Benzoil- $N^{2}$-(terc-butil)- $N^{3}$-ciklopropil-2-metilaziridin-2,3-dikarboxamid $(( \pm)$ 287)

A terméket a 4.8. általános szintézismódszer alapján állítottuk elő.

( \pm )-287: 76 mg (74 \%); fehér, szilárd; Op. $155-157{ }^{\circ} \mathrm{C} ; \mathrm{R}_{f}=0,33$ (toluol/MeCN = 2/1).

( \pm )-transz-1-Benzoil- $N^{2}$-(terc-butil)-2-metil- $N^{3}$-(prop-2-in-1-il)-aziridin-2,3-dikarboxamid $(( \pm)-288)$

A terméket a 4.8. általános szintézismódszer alapján állítottuk elő.

( \pm )-288: $87 \mathrm{mg}$ (85 \%); fehér, szilárd; Op. $159-160{ }^{\circ} \mathrm{C} ; \mathrm{R}_{f}=0,45$ (toluol/MeCN = 2/1).

( \pm )-transz-1-Benzoil- $N^{2}$-(terc-butil)-2-metil- $N^{3}$-fenilaziridin-2,3-dikarboxamid $(( \pm)$-289)

A terméket a 4.8. általános szintézismódszer alapján állítottuk elő.

( \pm )-289: 108 mg (95\%); fehér, szilárd; Op. $188-190{ }^{\circ} \mathrm{C} ; \mathrm{R}_{f}=0,28$ (hexán/EtOAc = 2/1).

$( \pm)$-transz-1-Benzoil- $N^{2}$-ciklohexil- $N^{3}$-ciklopropil-2-metilaziridin-2,3-dikarboxamid $\quad(( \pm)$ 290)

A terméket a 4.8. általános szintézismódszer alapján állítottuk elő.

( \pm )-290: 102 mg (92\%); fehér, szilárd; Op. 193-195 ${ }^{\circ} \mathrm{C} ; \mathrm{R}_{f}=0,31$ (toluol/MeCN = 2/1).

$( \pm)$-transz-1-Benzoil- $N^{2}$-(terc -butil)- $N^{3}$-ciklobutil-2-metilaziridin-2,3-dikarboxamid $\quad(( \pm)$ 291)

A terméket a 4.8. általános szintézismódszer alapján állítottuk elő.

( \pm )-291: 85 mg (71 \%); fehér, szilárd; Op. 209-211 ${ }^{\circ} \mathrm{C} ; \mathrm{R}_{f}=0,46$ (toluol/MeCN = 2/1).

( \pm )-transz-1-benzoil- $N^{3}$-ciklopropil-2-metil- $N^{2}$-(2,4,4-trimetilpentán-2-il)-aziridin-2,3dikarboxamid (( \pm$)-292)$ 
A terméket a 4.8. általános szintézismódszer alapján állítottuk elő.

( \pm )-292: 104 mg (87 \%); fehér, szilárd; Op. $147-148{ }^{\circ} \mathrm{C} ; \mathrm{R}_{f}=0,56$ (toluol/MeCN = 2/1).

\subsection{A ( \pm )-transz-etil-3-(terc-butilkarbamoil)-3-metilaziridin-2-karboxilát előállítása $(( \pm)-293)$}

A ( \pm )-281 $\{10\} N$-acilaziridin $(200 \mathrm{mg}, 0,6 \mathrm{mmol})$ etanolos $(0,8 \mathrm{ml})$ oldatához jeges hủtés mellett nátrum-bórhidridet ( $35 \mathrm{mg}, 0,9 \mathrm{mmol}$ ) adagoltunk, majd a reakcióelegyet szobahőmérsékleten 2 órán keresztül kevertettük. Ezt követően vizet $(10 \mathrm{ml})$ adtunk hozzá és etil-acetáttal $(2 \times 15 \mathrm{ml})$ extraháltuk. Az egyesített szerves fázist $\mathrm{Na}_{2} \mathrm{SO}_{4}$-on szárítottuk, bepároltuk, majd oszlopkromatográfiával (toluol/MeCN $=8 / 1$, szilikagél) tisztítottuk.

( \pm )-293: $126 \mathrm{mg}$ (92\%); fehér, szilárd; Op. $60-62{ }^{\circ} \mathrm{C} ; \mathrm{R}_{f}=0,56$ (toluol/MeCN = 3/1).

\subsection{A ( \pm )-294-297 oxazolinok előállításának általános leírása}

\section{$\underline{\text { A-módszer }}^{203}$}

A $281\{1\}$ (transz) vagy 282 $\{1\}$ (cisz) $N$-acilaziridint (166 mg, $5 \mathrm{mmol}$ ) DMF-ban (8 mL) oldottuk, majd nátrium-jodidot $(187 \mathrm{mg}, 1,25 \mathrm{mmol})$ adtunk hozzá és $100{ }^{\circ} \mathrm{C}$-on 12 órát kevertettük. Ezt követően a reakcióelegyhez vizet $(10 \mathrm{ml})$ öntöttünk és etil-acetáttal $(2 \times 15 \mathrm{ml})$ extraháltuk. Az egyesített szerves fázist $\mathrm{Na}_{2} \mathrm{SO}_{4}$-on szárítottuk, bepároltuk, majd oszlopkromatográfiával (hexán/EtOAc $=6 / 1$, szilikagél) tisztítottuk.

$\underline{\text { B-módszer }}^{89}$

A $281\{1\}$ (transz) vagy $282\{1\}$ (cisz) $N$-acilaziridint (166 mg, $5 \mathrm{mmol}$ ) diklórmetánban (10 mL) oldottuk, majd $\mathrm{BF}_{3} \cdot 2 \mathrm{H}_{2} \mathrm{O}$-ot $(95 \mu 1,1,5 \mathrm{mmol})$ adtunk hozzá és szobahőmérsékleten 6 órát kevertettük. Ezt követően a reakcióelegyhez telített vizes $\mathrm{NaHCO}_{3}$ oldatot $(15 \mathrm{ml})$ öntöttünk és diklórmetánnal $(2 \times 15 \mathrm{ml})$ extraháltuk. Az egyesített szerves fázist $\mathrm{Na}_{2} \mathrm{SO}_{4}$-on szárítottuk, bepároltuk, majd oszlopkromatográfiával (hexán/EtOAc $=4 / 1$, szilikagél) tisztítottuk.

( \pm )-Etil-transz-4-(terc-butilkarbamoil)-4-metil-2-fenil-4,5-dihidrooxazol-5-karboxilát $(( \pm)-$ 294)

A terméket a 4.10. A-módszer alapján állítottuk elő, 281 \{1\} N-acilaziridinből kiindulva.

( \pm )-294: $130 \mathrm{mg}\left(78 \%\right.$ ); fehér, szilárd; Op. $91-92{ }^{\circ} \mathrm{C} ; \mathrm{R}_{f}=0,53$ (hexán/EtOAc $=3 / 1$ ). 
A terméket a 4.10. A-módszer alapján állítottuk elő, 282\{1\} N-acilaziridinből kiindulva.

( \pm )-295: 133 mg (80\%); színtelen, olaj; $\mathrm{R}_{f}=0,60($ hexán/EtOAc $=3 / 1)$.

( \pm )-Etil-transz-5-(terc-butilkarbamoil)-5-metil-2-fenil-4,5-dihidrooxazol-4-karboxilát $(( \pm)$ 296)

A terméket a 4.10. B-módszer alapján állítottuk elő, 281\{1\} N-acilaziridinből kiindulva.

( \pm )-296: $141 \mathrm{mg}$ (85 \%); fehér, szilárd; Op. 98-100 ${ }^{\circ} \mathrm{C} ; \mathrm{R}_{f}=0,38$ (hexán/EtOAc $=3 / 1$ ).

( \pm )-Etil-cisz-5-(terc-butilkarbamoil)-5-metil-2-fenil-4,5-dihidrooxazol-4-karboxilát

$(( \pm)-$ 297)

A terméket a 4.10. B-módszer alapján állítottuk elő, 282\{1\} N-acilaziridinből kiindulva.

( \pm )-297: 120 mg (72\%); színtelen, olaj; $\mathrm{R}_{f}=0,44$ (hexán/EtOAc = 3/1).

4.11. Az etil-2-benzamido-4-(terc-butilamino)-3-hidroxi-3-metil-4-oxobutanoát (( \pm$)$-298a vagy $( \pm)-298 b)$ előállítása

A ( \pm )-281 $\{1\} N$-acilaziridint (100 $\mathrm{mg}, 0,3 \mathrm{mmol})$ acetonitrilben $(1 \mathrm{ml})$ oldottunk, majd az oldathoz szkandium-triflátot (37 mg, $25 \mathrm{~mol} \%$ ) és vizet ( $56 \mu 1,3 \mathrm{mmol}$ ) adtunk. A reakcióelegyet szobahőmérsékleten 24 órát kevertettük, majd bepároltuk, vizet $(5 \mathrm{ml})$ adtunk hozzá és etilacetáttal $(2 \times 5 \mathrm{ml})$ extraháltuk. Az egyesített szerves fázist $\mathrm{Na}_{2} \mathrm{SO}_{4}$-on szárítottuk, bepároltuk, majd oszlopkromatográfiával (hexán/EtOAc $=4 / 1$, szilikagél) tisztítottuk.

( \pm )-298a vagy ( \pm )-298b: 75 mg (71\%); fehér, szilárd; Op. $141-143{ }^{\circ} \mathrm{C} ; \mathrm{R}_{f}=0,55$ (hexán/EtOAc $=1 / 1)$.

4.12. A ( $( \pm)-301 a-328$ a és $( \pm)-301 b$ spirooxindol-imidazolidinek előállításának általános leírása

A megfelelő izatint (299a-g, 0,5 mmol) vízmentes DMSO-ban (2 ml) oldottuk, majd a megfelelő a-aminosavat (300a-m, 0,6 mmol) és $2 H$-azirint (270a,b,e-j, 0,5 mmol) adtunk hozzá. A reakcióelegyet $60^{\circ} \mathrm{C}$-on 8 órát kevertettük argon atmoszféra alatt. Ezután a reakcióelegyet vízre $(50 \mathrm{ml})$ öntöttük és dietil-éterrel $(3 \times 10 \mathrm{ml})$ extraháltuk. Az egyesített szerves fázist $\mathrm{Na}_{2} \mathrm{SO}_{4}$-on szárítottuk, majd bepároltuk és oszlopkromatográfiával (eluens: hexán/kloroform vagy kloroform/metanol, szilikagél) tisztítottuk. 
( \pm )-(2R,3'R,5S,6S)-Etil-5-metil-2'-oxo-2-fenil-1,3-diazaspiro[biciklo[3.1.0]hexán-4,3'indolin]-6-karboxilát $(( \pm)-301 a)$

A terméket a 4.12. általános szintézismódszer alapján állítottuk elő.

(土)-301a: $118 \mathrm{mg}$ (65\%); fehér, szilárd; Op. $172-174{ }^{\circ} \mathrm{C} ; \mathrm{R}_{f}=0,44\left(\mathrm{CHCl}_{3} / \mathrm{MeOH}=19 / 1\right)$.

( \pm )-(2R,3'S,5R,6R)-Etil-5-metil-2'-oxo-2-fenil-1,3-diazaspiro[biciklo[3.1.0]hexán-4,3'indolin]-6-karboxilát (( \pm )-301b)

A terméket a 4.12. általános szintézismódszer alapján, egy méretnövelt szintézissel (5 mmol izatinból kiindulva) állítottuk elő.

( \pm )-301b: 55 mg (3 \%); fehér, szilárd; Op. $198-199{ }^{\circ} \mathrm{C}$; $\mathrm{R}_{f}=0,55\left(\mathrm{CHCl}_{3} / \mathrm{MeOH}=19 / 1\right)$.

( \pm )-(2R,3'R,5S,6S)-Etil-5'-klór-5-metil-2'-oxo-2-fenil-1,3-diazaspiro[biciklo[3.1.0]hexán4,3'-indolin]-6-karboxilát (( \pm$)-302 a)$

A terméket a 4.12. általános szintézismódszer alapján állítottuk elő.

( \pm )-302a: $155 \mathrm{mg}$ (78 \%); bézs, szilárd; Op. $235-236{ }^{\circ} \mathrm{C} ; \mathrm{R}_{f}=0,23\left(\mathrm{CHCl}_{3} / \mathrm{MeOH}=19 / 1\right)$.

( \pm )-(2R,3' $R, 5 S, 6 S)$-Etil-7'-bróm-5-metil-2'-oxo-2-fenil-1,3-diazaspiro[biciklo[3.1.0]hexán4,3'-indolin]-6-karboxilát (( \pm$)-303 a)$

A terméket a 4.12. általános szintézismódszer alapján állítottuk elő.

( \pm )-303a: $97 \mathrm{mg}$ (44\%); halványsárga, szilárd; Op. $115-116{ }^{\circ} \mathrm{C} ; \mathrm{R}_{f}=0,29\left(\mathrm{CHCl}_{3} / \mathrm{MeOH}=\right.$ 19/1).

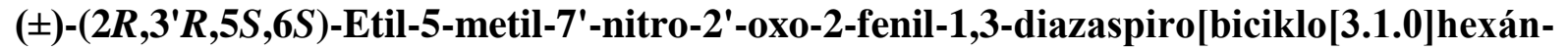
4,3'-indolin]-6-karboxilát $(( \pm)-304 a)$

A terméket a 4.12. általános szintézismódszer alapján állítottuk elő.

(土)-304a: $102 \mathrm{mg}$ (50\%); halványsárga, szilárd; Op. $158-160{ }^{\circ} \mathrm{C} ; \mathrm{R}_{f}=0,33\left(\mathrm{CHCl}_{3} / \mathrm{MeOH}=\right.$ 19/1).

$( \pm)-(2 R, 3 ' R, 5 S, 6 S)-E t i l-6 '-m e t o x i-5-m e t i l-2 '-0 x 0-2-f e n i l-1,3-d i a z a s p i r o[b i c i k l o[3.1 .0]$ hexán-4,3'-indolin]-6-karboxilát (( \pm -305a)

A terméket a 4.12. általános szintézismódszer alapján állítottuk elő.

(土)-305a: $124 \mathrm{mg}$ (63\%); halványsárga, szilárd; Op. 218-220 ${ }^{\circ} \mathrm{C} ; \mathrm{R}_{f}=0,15\left(\mathrm{CHCl}_{3} / \mathrm{MeOH}=\right.$ 19/1). 
( \pm )-(2R,3' $R, 5 S, 6 S)$-Etil-1',5-dimetil-2'-oxo-2-fenil-1,3-diazaspiro[biciklo[3.1.0]hexán-4,3'indolin]-6-karboxilát (( \pm -306a)

A terméket a 4.12. általános szintézismódszer alapján állítottuk elő.

( \pm )-306a: 132 mg (70\%); fehér, szilárd; Op. $167-169^{\circ} \mathrm{C} ; \mathrm{R}_{f}=0,38\left(\mathrm{CHCl}_{3} / \mathrm{MeOH}=19 / 1\right)$.

$( \pm)-(2 R, 3 ' R, 5 S, 6 S)$-Etil-1'-benzil-5-metil-2'-oxo-2-fenil-1,3-diazaspiro[biciklo[3.1.0] hexán4,3'-indolin]-6-karboxilát (( \pm )-307a)

A terméket a 4.12. általános szintézismódszer alapján állítottuk elő.

(土)-307a: 104 mg (55\%); bézs, szilárd; Op. 76-78 ${ }^{\circ} \mathrm{C} ; \mathrm{R}_{f}=0,21$ (hexán/EtOAc = 2/1).

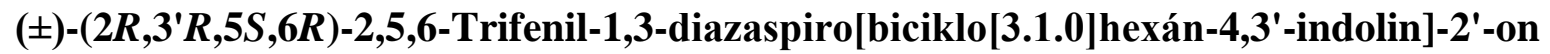
$(( \pm)-308 a)$

A terméket a 4.12. általános szintézismódszer alapján állítottuk elő.

(土)-308a: $140 \mathrm{mg}$ (65 \%); fehér, szilárd; Op. $230-232{ }^{\circ} \mathrm{C} ; \mathrm{R}_{f}=0,26\left(\mathrm{CHCl}_{3} / \mathrm{MeOH}=19 / 1\right)$.

( \pm )-(2R,3'R,5S,6R)-5-(4-Metoxifenil)-2,6-difenil-1,3-diazaspiro[biciklo[3.1.0]hexán-4,3'indolin]-2'-on (( \pm -309a)

A terméket a 4.12. általános szintézismódszer alapján állítottuk elö.

( \pm )-309a: 163 mg (71\%); fehér, szilárd; Op. $174-177^{\circ} \mathrm{C} ; \mathrm{R}_{f}=0,38\left(\mathrm{CHCl}_{3} / \mathrm{MeOH}=19 / 1\right)$.

( \pm )-(2R,3'R,5S,6R)-5-(4-Klórfenil)-2,6-difenil-1,3-diazaspiro[biciklo[3.1.0]hexán-4,3'indolin]-2'-on (( \pm -310a)

A terméket a 4.12. általános szintézismódszer alapján állítottuk elő.

( \pm )-310a: 155 mg (67 \%); fehér, szilárd; Op. 222-224 ${ }^{\circ} \mathrm{C} ; \mathrm{R}_{f}=0,31\left(\mathrm{CHCl}_{3} / \mathrm{MeOH}=19 / 1\right)$.

( \pm )-(2R,3' $R, 5 S, 6 R)-5$-(4-Fluorfenil)-2,6-difenil-1,3-diazaspiro[biciklo[3.1.0]hexán-4,3'indolin]-2'-on (( \pm )-311a)

A terméket a 4.12. általános szintézismódszer alapján állítottuk elö.

( \pm )-311a: 174 mg (78 \%); fehér, szilárd; Op. 216-218 ${ }^{\circ} \mathrm{C} ; \mathrm{R}_{f}=0,32\left(\mathrm{CHCl}_{3} / \mathrm{MeOH}=19 / 1\right)$.

( \pm )-(2R,3'R,5S,6R)-5-Benzil-2,6-difenil-1,3-diazaspiro[biciklo[3.1.0]hexán-4,3'-indolin]-2'on $(( \pm)-312 a)$

A terméket a 4.12. általános szintézismódszer alapján állítottuk elö.

( \pm )-312a: $71 \mathrm{mg}(32 \%)$; fehér, szilárd; Op. $248-249{ }^{\circ} \mathrm{C} ; \mathrm{R}_{f}=0,26\left(\mathrm{CHCl}_{3} / \mathrm{MeOH}=19 / 1\right)$. 
( \pm )-(2R,3' $R, 5 S, 6 S)$-terc-Butil-5-metil-2'-oxo-2-fenil-1,3-diazaspiro[biciklo[3.1.0]hexán-4,3'indolin]-6-karboxilát $(( \pm)-313 a)$

A terméket a 4.12. általános szintézismódszer alapján állítottuk elő.

(土)-313a: 129 mg (66 \%); fehér, szilárd; Op. 235-236 ${ }^{\circ} \mathrm{C} ; \mathrm{R}_{f}=0,14\left(\mathrm{CHCl}_{3} / \mathrm{MeOH}=19 / 1\right)$.

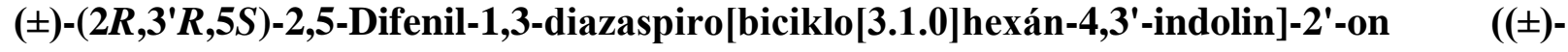
314a)

A terméket a 4.12. általános szintézismódszer alapján állítottuk elő.

( \pm )-314a: 134 mg (76 \%); fehér, szilárd; Op. $216-217^{\circ} \mathrm{C} ; \mathrm{R}_{f}=0,20\left(\mathrm{CHCl}_{3} / \mathrm{MeOH}=19 / 1\right)$.

( \pm )-(2R,3' $R, 5 S, 6 R)-5$-(4-Klórfenil)-6'-metoxi-2,6-difenil-1,3-diazaspiro[biciklo[3.1.0] hexán-4,3'-indolin]-2'-on (( $( \pm)-315 a)$

A terméket a 4.12. általános szintézismódszer alapján állítottuk elő.

(土)-315a: 167 mg (68 \%); fehér, szilárd; Op. $240-241^{\circ} \mathrm{C} ; \mathrm{R}_{f}=0,30\left(\mathrm{CHCl}_{3} / \mathrm{MeOH}=19 / 1\right)$.

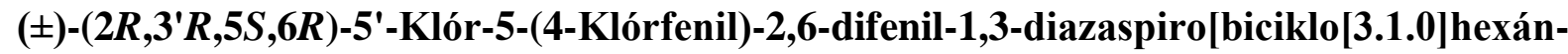
4,3'-indolin]-2'-on (( \pm -316a)

A terméket a 4.12. általános szintézismódszer alapján állítottuk elö.

(土)-316a: $181 \mathrm{mg}(73 \%)$; fehér, szilárd; Op. $246-247^{\circ} \mathrm{C} ; \mathrm{R}_{f}=0,38\left(\mathrm{CHCl}_{3} / \mathrm{MeOH}=19 / 1\right)$.

( \pm )-(2R,3' $R, 5 S, 6 S)$-Etil-5-metil-2'-oxo-2-(p-tolil)-1,3-diazaspiro[biciklo[3.1.0]hexán-4,3'indolin]-6-karboxilát (( \pm$)-317 a)$

A terméket a 4.12. általános szintézismódszer alapján állítottuk elő.

( \pm )-317a: 153 mg (81 \%); fehér, szilárd; Op. 208-209 ${ }^{\circ} \mathrm{C} ; \mathrm{R}_{f}=0,17\left(\mathrm{CHCl}_{3} / \mathrm{MeOH}=19 / 1\right)$.

( \pm )-(2R,3'R,5S,6S)-Etil-2-(4-klórfenil)-5-metil-2'-oxo-1,3-diazaspiro[biciklo[3.1.0]hexán4,3'-indolin]-6-karboxilát (( \pm -318a)

A terméket a 4.12. általános szintézismódszer alapján állítottuk elö.

( \pm )-318a: 143 mg (72\%); fehér, szilárd; Op. $231-232{ }^{\circ} \mathrm{C} ; \mathrm{R}_{f}=0,19\left(\mathrm{CHCl}_{3} / \mathrm{MeOH}=19 / 1\right)$.

( \pm )-(2R,3' $R, 5 S, 6 S)$-Etil-2-(4-fluorfenil)-5-metil-2'-oxo-1,3-diazaspiro[biciklo[3.1.0]hexán4,3'-indolin]-6-karboxilát (( \pm$)-319 a)$

A terméket a 4.12. általános szintézismódszer alapján állítottuk elö.

( \pm )-319a: 130 mg (68 \%); fehér, szilárd; Op. $211-212{ }^{\circ} \mathrm{C} ; \mathrm{R}_{f}=0,19\left(\mathrm{CHCl}_{3} / \mathrm{MeOH}=19 / 1\right)$. 
( \pm )-(2R,3' $R, 5 S, 6 S)$-Etil-2-benzil-5-metil-2' -oxo-1,3-diazaspiro[biciklo[3.1.0]hexán-4,3'indolin]-6-karboxilát $(( \pm)-320 a)$

A terméket a 4.12. általános szintézismódszer alapján állítottuk elő.

( \pm )-320a: 130 mg (69\%); fehér, szilárd; Op. $167-168^{\circ} \mathrm{C} ; \mathrm{R}_{f}=0,26\left(\mathrm{CHCl}_{3} / \mathrm{MeOH}=19 / 1\right)$.

$( \pm)-\left(2 R, 3^{\prime} R, 5 S, 6 S\right)$-Etil-2-(4-hidroxibenzil)-5-metil-2'-oxo-1,3-diazaspiro[biciklo[3.1.0] hexán-4,3'-indolin]-6-karboxilát (( \pm -321a)

A terméket a 4.12. általános szintézismódszer alapján állítottuk elő.

( \pm )-321a: 120 mg (61 \%); fehér, szilárd; Op. 206-208 ${ }^{\circ} \mathrm{C} ; \mathrm{R}_{f}=0,10\left(\mathrm{CHCl}_{3} / \mathrm{MeOH}=19 / 1\right)$.

( \pm )-(2R,3' $R, 5 S, 6 S)$-Etil-5-metil-2'-oxo-2-fenetil-1,3-diazaspiro[biciklo[3.1.0]hexán-4,3'indolin]-6-karboxilát (( \pm$)-322 a)$

A terméket a 4.12. általános szintézismódszer alapján állítottuk elő.

(土)-322a: $123 \mathrm{mg}$ (63\%); fehér, szilárd; Op. $171-172{ }^{\circ} \mathrm{C} ; \mathrm{R}_{f}=0,25\left(\mathrm{CHCl}_{3} / \mathrm{MeOH}=19 / 1\right)$.

( $\left.{ }^{ \pm}\right)-(2 R, 3 ' R, 5 S, 6 S)$-Etil-2-((benziltio)-metil)-5-metil-2'-oxo-1,3-diazaspiro[biciklo[3.1.0] hexán-4,3'-indolin]-6-karboxilát (( \pm -323a)

A terméket a 4.12. általános szintézismódszer alapján állítottuk elő.

( \pm )-323a: 78 mg (37\%); halványsárga, szilárd; Op. $144-146{ }^{\circ} \mathrm{C} ; \mathrm{R}_{f}=0,25\left(\mathrm{CHCl}_{3} / \mathrm{MeOH}=\right.$ $19 / 1)$.

$( \pm)-(2 R, 3 ' R, 5 S, 6 S)$-Etil-2-((1H-indol-3-il)-metil)-5-metil-2' -oxo-1,3-diazaspiro[biciklo [3.1.0]hexán-4,3'-indolin]-6-karboxilát $(( \pm)-324 a)$

A terméket a 4.12. általános szintézismódszer alapján állítottuk elö.

( \pm )-324a: 137 mg (66 \%); bézs, szilárd; Op. 237-238 ${ }^{\circ} \mathrm{C} ; \mathrm{R}_{f}=0,11\left(\mathrm{CHCl}_{3} / \mathrm{MeOH}=19 / 1\right)$.

( \pm )-(2R,3' $R, 5 S, 6 S)$-Etil-2-(hidroximetil)-5-metil-2'-oxo-1,3-diazaspiro[biciklo[3.1.0] hexán4,3'-indolin]-6-karboxilát (( \pm -325a)

A terméket a 4.12. általános szintézismódszer alapján állítottuk elö.

( \pm )-325a: 73 mg (46 \%); halványsárga, szilárd; Op. $148-149{ }^{\circ} \mathrm{C} ; \mathrm{R}_{f}=0,43\left(\mathrm{CHCl}_{3} / \mathrm{MeOH}=\right.$ $19 / 1)$.

$( \pm)-(2 R, 3 ' R, 5 S, 6 S)$-Etil-2-(3-amino-3-oxopropil)-5-metil-2'-oxo-1,3-diazaspiro[biciklo

[3.1.0]hexán-4,3'-indolin]-6-karboxilát (( \pm$)$-326a)

A terméket a 4.12. általános szintézismódszer alapján állítottuk elő.

( \pm )-326a: $101 \mathrm{mg}$ (56 \%); fehér, szilárd; Op. $232-233{ }^{\circ} \mathrm{C} ; \mathrm{R}_{f}=0,26\left(\mathrm{CHCl}_{3} / \mathrm{MeOH}=19 / 1\right)$. 
( \pm )-(2R,3' $R, 5 S, 6 S)$-Etil-2-butil-5-metil-2'-oxo-1,3-diazaspiro[biciklo[3.1.0]hexán-4,3'indolin]-6-karboxilát $(( \pm)-327 a)$

A terméket a 4.12. általános szintézismódszer alapján állítottuk elő.

(士)-327a: $120 \mathrm{mg}(70 \%)$; fehér, szilárd; Op. $168-169^{\circ} \mathrm{C} ; \mathrm{R}_{f}=0,19\left(\mathrm{CHCl}_{3} / \mathrm{MeOH}=19 / 1\right)$.

$( \pm)-(1 R, 2 \mathrm{a} S, 3 ' S, 7 \mathrm{a} R)$-Etil-7a-metil-2'-oxo-1,2a,3,4,5,7a-hexahidrospiro[azirino[1,2c]pirrolo[1,2-a]imidazol-7,3'-indolin]-1-karboxilát (( \pm$)-328 a)$

A terméket a 4.12. és 4.13 (lentebb) általános szintézismódszer alapján is előállítottuk.

A 4.12 általános szintézismódszer alapján előállított $( \pm)$-328a: 18 mg (11\%); halványsárga, szilárd; Op. $147-148{ }^{\circ} \mathrm{C} ; \mathrm{R}_{f}=0,16\left(\mathrm{CHCl}_{3} / \mathrm{MeOH}=19 / 1\right)$.

\subsection{A ( \pm -328a-333a spirooxindol-imidazolidinek előállításának általános leírása}

L-prolint (300m, 69 mg, 0,6 mmol) vízmentes IPA-ban (8 ml) oldottuk, majd megfelelő izatint (299a,b,e,f, 0,5 mmol) és $2 H$-azirint (270a,e, 1,5 mmol) adtunk hozzá. A reakcióelegyet szobahőmérsékleten, argon atmoszféra alatt 24 órát kevertettük, majd a reakció lejátszódását követően a reakcióelegyet bepároltuk és oszlopkromatográfiával (eluens: hexán/EtOAc, szilikagél) tisztítottuk.

( \pm )-(1R,2aS,3' $S, 7 \mathrm{a} R)$-Etil-7a-metil-2'-oxo-1,2a,3,4,5,7a-hexahidrospiro[azirino[1,2c]pirrolo[1,2-a]imidazol-7,3'-indolin]-1-karboxilát (( \pm$)-328 a)$

A terméket a 4.12. (fentebb) és 4.13 általános szintézismódszer alapján is előállítottuk.

A 4.13 általános szintézismódszer alapján előállított ( \pm )-328a: 98 mg (60\%); halványsárga, szilárd; Op. $147-148{ }^{\circ} \mathrm{C} ; \mathrm{R}_{f}=0,16\left(\mathrm{CHCl}_{3} / \mathrm{MeOH}=19 / 1\right)$.

( \pm )-(1R,2aS,3' $S, 7 \mathrm{a} R)$-Etil-5'-klór-7a-metil-2'-oxo-1,2a,3,4,5,7a-hexahidrospiro[azirino [1,2-c]pirrolo[1,2-a]imidazol-7,3'-indolin]-1-karboxilát (( \pm )-329a)

A terméket a 4.13. általános szintézismódszer alapján állítottuk elő.

(土)-329a: 99 mg (55 \%); halványsárga, szilárd; Op. 235-236 ${ }^{\circ} \mathrm{C} ; \mathrm{R}_{f}=0,17\left(\mathrm{CHCl}_{3} / \mathrm{MeOH}=\right.$ $19 / 1)$.

( \pm )-(1R,2aS,3' $S, 7 \mathrm{a} R)$-Etil-6'-metoxi-7a-metil-2'-oxo-1,2a,3,4,5,7a-hexahidrospiro[azirino [1,2-c]pirrolo[1,2-a]imidazol-7,3'-indolin]-1-karboxilát (( \pm -330a)

A terméket a 4.13. általános szintézismódszer alapján állítottuk elő.

( \pm )-330a: $121 \mathrm{mg}$ (68 \%); bézs, szilárd; Op. $142-144{ }^{\circ} \mathrm{C} ; \mathrm{R}_{f}=0,16\left(\mathrm{CHCl}_{3} / \mathrm{MeOH}=19 / 1\right)$. 
( \pm )-(1R,2a $S, 3 ' S, 7 \mathrm{a} R)$-Etil-1',7a-dimetil-2'-oxo-1,2a,3,4,5,7a-hexahidrospiro[azirino[1,2c]pirrolo[1,2-a]imidazol-7,3'-indolin]-1-karboxilát (( \pm -331a)

A terméket a 4.13. általános szintézismódszer alapján állítottuk elő.

(士)-331a: 106 mg (62 \%); fehér, szilárd; Op. $117-118^{\circ} \mathrm{C} ; \mathrm{R}_{f}=0,40\left(\mathrm{CHCl}_{3} / \mathrm{MeOH}=19 / 1\right)$.

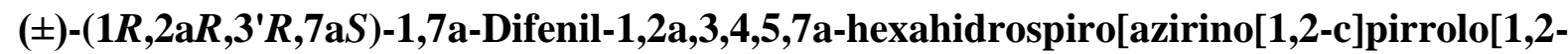
a]imidazol-7,3'-indolin]-2' -on (( \pm )-332a)

A terméket a 4.13. általános szintézismódszer alapján állítottuk elő.

( \pm )-332a: $65 \mathrm{mg}(33 \%)$; fehér, szilárd; Op. $217-218^{\circ} \mathrm{C}$; $\mathrm{R}_{f}=0,39\left(\mathrm{CHCl}_{3} / \mathrm{MeOH}=19 / 1\right)$.

( \pm )-(1R,2a $R, 3 ' R, 7 \mathrm{a} S)-5$ '-Klór-1,7a-difenil-1,2a,3,4,5,7a-hexahidrospiro[azirino[1,2c]pirrolo[1,2-a]imidazol-7,3'-indolin]-2'-on (( \pm )-333a)

A terméket a 4.13. általános szintézismódszer alapján állítottuk elő.

( \pm )-333a: 100 mg (47 \%); fehér, szilárd; Op. $218-219{ }^{\circ} \mathrm{C} ; \mathrm{R}_{f}=0,10$ (hexán/EtOAc = 2/1).

\subsection{A 336-377 imidazolok előállításának általános leírása}

A megfelelő nitron (334a-r, $1 \mathrm{mmol})$ és $2 H$-azirin $(( \pm)-270 a, b, e-\mathbf{j}, 1,5 \mathrm{mmol})$ vízmentes acetonitriles $(3 \mathrm{ml})$ oldatához szobahőmérsékleten TFA-t (10 mol\%) adtunk. A reakcióelegyet $60{ }^{\circ} \mathrm{C}$-on 6 órán át, az azirin teljes konverziójáig kevertettük. Bepárlást követően a nyersterméket oszlopkromatográfiával tisztítottuk (szilikagél, eluens: hexán/EtOAc vagy toluol/MeCN, gradiens elúció).

A kiindulási nitronok szintézisét szakirodalomban ismertetett módszerek alapján végeztük. ${ }^{204,205}$

Etil-1,5-dimetil-2-fenil-1 $H$-imidazol-4-karboxilát (336)

A terméket a 4.14. általános szintézismódszer alapján állítottuk elő.

336: 175 mg (72\%); fehér, szilárd; Op. $84-85^{\circ} \mathrm{C} ; \mathrm{R}_{f}=0,20$ (hexán/EtOAc $\left.=1 / 1\right)$.

Etil-2-(4-metoxifenil)-1,5-dimetil-1H-imidazol-4-karboxilát (337)

A terméket a 4.14. általános szintézismódszer alapján állítottuk elő.

337: 187 mg (68\%); fehér, szilárd; Op. $98-99^{\circ} \mathrm{C} ; \mathrm{R}_{f}=0,11$ (hexán/EtOAc $\left.=1 / 1\right)$.

Etil-2-(4-fluorfenil)-1,5-dimetil-1 $H$-imidazol-4-karboxilát (338)

A terméket a 4.14. általános szintézismódszer alapján állítottuk elő.

338: $204 \mathrm{mg}$ (78\%); fehér, szilárd; Op. $98-100{ }^{\circ} \mathrm{C} ; \mathrm{R}_{f}=0,23$ (hexán/EtOAc $=1 / 1$ ). 
Etil-1,5-dimetil-2-(4-nitrofenil)-1H-imidazol-4-karboxilát (339)

A terméket a 4.14. általános szintézismódszer alapján állítottuk elö.

339: 200 mg (69\%); fehér, szilárd; Op. $145-146^{\circ} \mathrm{C} ; \mathrm{R}_{f}=0,35$ (hexán/EtOAc $=1 / 1$ ).

Etil-1,5-dimetil-2-(piridin-2-il)-1H-imidazol-4-karboxilát (340)

A terméket a 4.14. általános szintézismódszer alapján állítottuk elő.

340: 201 mg (82\%); halványsárga, szilárd; Op. 114-115 ${ }^{\circ} \mathrm{C} ; \mathrm{R}_{f}=0,13$ (hexán/EtOAc = 1/1).

Etil-1,5-dimetil-2-(piridin-3-il)-1H-imidazol-4-karboxilát (341)

A terméket a 4.14. általános szintézismódszer alapján állítottuk elő.

341: $198 \mathrm{mg}(81 \%)$; narancssárga, olaj; $\mathrm{R}_{f}=0,52$ (kloroform $\left./ \mathrm{MeOH}=19 / 1\right)$.

Etil-1,5-dimetil-2-(5-metilfurán-2-il)-1H-imidazol-4-karboxilát (342)

A terméket a 4.14. általános szintézismódszer alapján állítottuk elő.

342: 102 mg (41\%); sárga, szilárd; Op. $68-69^{\circ} \mathrm{C} ; \mathrm{R}_{f}=0,20$ (hexán/EtOAc $=1 / 1$ ).

Etil-1,2,5-trimetil-1H-imidazol-4-karboxilát (343)

A terméket a 4.14. általános szintézismódszer alapján állítottuk elő.

343: 127 mg (81\%); halványsárga, olaj; $\mathrm{R}_{f}=0,41$ (kloroform $\left./ \mathrm{MeOH}=19 / 1\right)$.

Etil-2-izopropil-1,5-dimetil-1H-imidazol-4-karboxilát (344)

A terméket a 4.14. általános szintézismódszer alapján állítottuk elö.

344: 111 mg (53\%); halványsárga, szilárd; Op. $73-74{ }^{\circ} \mathrm{C} ; \mathrm{R}_{f}=0,07$ (hexán/EtOAc $=1 / 1$ ).

Etil-2-(terc-butil)-1,5-dimetil-1H-imidazol-4-karboxilát (345)

A terméket a 4.14. általános szintézismódszer alapján állítottuk elő.

345: $110 \mathrm{mg}(49 \%)$; halványsárga, olaj; $\mathrm{R}_{f}=0,38($ hexán/EtOAc $=1 / 1)$.

Etil-2-heptil-1,5-dimetil-1H-imidazol-4-karboxilát (346)

A terméket a 4.14. általános szintézismódszer alapján állítottuk elő.

346: $144 \mathrm{mg}(54 \%)$; halványsárga, olaj; $\mathrm{R}_{f}=0,21$ (hexán/EtOAc $\left.=1 / 1\right)$.

Etil-2-ciklopropil-1,5-dimetil-1H-imidazol-4-karboxilát (347)

A terméket a 4.14. általános szintézismódszer alapján állítottuk elő.

347: $150 \mathrm{mg}(72 \%)$; halványsárga, olaj; $\mathrm{R}_{f}=0,06$ (hexán/EtOAc $\left.=1 / 1\right)$.

Etil-2-ciklohexil-1,5-dimetil-1H-imidazol-4-karboxilát (348)

A terméket a 4.14. általános szintézismódszer alapján állítottuk elő.

348: $175 \mathrm{mg}$ (70\%); halványsárga, szilárd; Op. $85^{\circ} \mathrm{C} ; \mathrm{R}_{f}=0,23$ (hexán/EtOAc $=1 / 1$ ). 
Etil-1,2-diizopropil-5-metil-1H-imidazol-4-karboxilát (349)

A terméket a 4.14. általános szintézismódszer alapján állítottuk elő.

349: $130 \mathrm{mg}(55 \%)$; halványsárga, olaj; $\mathrm{R}_{f}=0,36$ (hexán/EtOAc $=1 / 1$ ).

\section{Etil-1-benzil-5-metil-2-fenil-1H-imidazol-4-karboxilát (350)}

A terméket a 4.14. általános szintézismódszer alapján állítottuk elő.

350: 203 mg (63\%); halványsárga, olaj; $\mathrm{R}_{f}=0,22($ hexán/EtOAc $=1 / 1)$.

Etil-1-benzil-2-izopropil-5-metil-1H-imidazol-4-karboxilát (351)

A terméket a 4.14. általános szintézismódszer alapján állítottuk elő.

351: 202 mg (71\%); halványsárga, olaj; $\mathrm{R}_{f}=0,39$ (hexán/EtOAc $=1 / 1$ ).

Etil-1-ciklohexil-5-metil-2-fenil-1H-imidazol-4-karboxilát (352)

A terméket a 4.14. általános szintézismódszer alapján állítottuk elő.

352: $116 \mathrm{mg}(37 \%)$; fehér, szilárd; Op. $103-105^{\circ} \mathrm{C} ; \mathrm{R}_{f}=0,50$ (hexán/EtOAc $=1 / 1$ ).

Etil-1-(4-fluorfenil)-5-metil-2-fenil-1H-imidazol-4-karboxilát (353)

A terméket a 4.14. általános szintézismódszer alapján állítottuk elő.

353: $135 \mathrm{mg}$ (42\%); bézs, szilárd; Op. $134-136{ }^{\circ} \mathrm{C} ; \mathrm{R}_{f}=0,87$ (hexán/EtOAc $=1 / 1$ ).

terc-Butil-1,5-dimetil-2-fenil-1H-imidazol-4-karboxilát (354)

A terméket a 4.14. általános szintézismódszer alapján állítottuk elö.

354: 183 mg (67\%); fehér, szilárd; Op. $224-225^{\circ} \mathrm{C} ; \mathrm{R}_{f}=0,25$ (hexán/EtOAc $=1 / 1$ ).

\section{1-Metil-2,4,5-trifenil-1H-imidazol (355)}

A terméket a 4.14. általános szintézismódszer alapján állítottuk elő.

355: 222 mg (72\%); fehér, szilárd; Op. $146-148{ }^{\circ} \mathrm{C} ; \mathrm{R}_{f}=0,78$ (hexán/EtOAc $=1 / 1$ ).

\section{5-(4-Metoxifenil)-1-metil-2,4-difenil-1 $H$-imidazol (356)}

A terméket a 4.14. általános szintézismódszer alapján állítottuk elő.

356: $239 \mathrm{mg}(70 \%)$; fehér, szilárd; Op. $157-158^{\circ} \mathrm{C} ; \mathrm{R}_{f}=0,69($ hexán/EtOAc $=1 / 1)$.

\section{5-(4-Fluorfenil)-1-metil-2,4-difenil-1H-imidazol (357)}

A terméket a 4.14. általános szintézismódszer alapján állítottuk elő.

357: $255 \mathrm{mg}$ (78\%); fehér, szilárd; Op. $168-170{ }^{\circ} \mathrm{C} ; \mathrm{R}_{f}=0,77$ (hexán/EtOAc $=1 / 1$ ).

\section{5-(4-Klórfenil)-1-metil-2,4-difenil-1H-imidazol (358)}

A terméket a 4.14. általános szintézismódszer alapján állítottuk elő.

358: 272 mg (79\%); fehér, szilárd; Op. $187-188^{\circ} \mathrm{C} ; \mathrm{R}_{f}=0,81$ (hexán/EtOAc $=1 / 1$ ). 


\section{5-Benzil-1-metil-2,4-difenil-1H-imidazol (359)}

A terméket a 4.14. általános szintézismódszer alapján állítottuk elő.

359: 146 mg (45\%); fehér, szilárd; Op. $160-161{ }^{\circ} \mathrm{C} ; \mathrm{R}_{f}=0,69$ (hexán/EtOAc $\left.=1 / 1\right)$.

\section{terc-Butil 2-izopropil-1,5-dimetil-1H-imidazol-4-karboxilát (361)}

A terméket a 4.14. általános szintézismódszer alapján állítottuk elö.

361: 116 mg (49\%); fehér, szilárd; Op. $99-101^{\circ} \mathrm{C} ; \mathrm{R}_{f}=0,26$ (hexán/EtOAc $=1 / 1$ ).

\section{2-Izopropil-1-metil-4,5-difenil-1H-imidazol (362)}

A terméket a 4.14. általános szintézismódszer alapján állítottuk elő.

362: 188 mg (68\%); fehér, szilárd; Op. $92-93{ }^{\circ} \mathrm{C} ; \mathrm{R}_{f}=0,70$ (hexán/EtOAc $\left.=1 / 1\right)$.

\section{2-Izopropil-5-(4-metoxifenil)-1-metil-4-fenil-1H-imidazol (363)}

A terméket a 4.14. általános szintézismódszer alapján állítottuk elő.

363: 204 mg (67\%); fehér, szilárd; Op. $156-158{ }^{\circ} \mathrm{C} ; \mathrm{R}_{f}=0,60$ (hexán/EtOAc $=1 / 1$ ).

\section{5-(4-Fluorfenil)-2-izopropil-1-metil-4-fenil-1 $H$-imidazol (364)}

A terméket a 4.14. általános szintézismódszer alapján állítottuk elő.

364: 216 mg (73\%); fehér, szilárd; Op. $138-139{ }^{\circ} \mathrm{C} ; \mathrm{R}_{f}=0,29$ (hexán/EtOAc $=1 / 1$ ).

\section{5-(4-Klórfenil)-2-izopropil-1-metil-4-fenil-1H-imidazol (365)}

A terméket a 4.14. általános szintézismódszer alapján állítottuk elő.

365: 224 mg (72\%); fehér, szilárd; Op. $132-133{ }^{\circ} \mathrm{C} ; \mathrm{R}_{f}=0,36$ (hexán/EtOAc $=1 / 1$ ).

\section{5-Benzil-2-izopropil-1-metil-4-fenil-1H-imidazol (366)}

A terméket a 4.14. általános szintézismódszer alapján állítottuk elő.

366: 166 mg (57\%); fehér, szilárd; Op. $104-106^{\circ} \mathrm{C} ; \mathrm{R}_{f}=0,58$ (hexán/EtOAc = 1/1).

\section{2-(4-Metoxifenil)-1-metil-4,5-difenil-1 $\mathrm{H}$-imidazol (368)}

A terméket a 4.14. általános szintézismódszer alapján állítottuk elő.

368: 234 mg (69\%); fehér, szilárd; Op. $169-171^{\circ} \mathrm{C} ; \mathrm{R}_{f}=0,65$ (hexán/EtOAc $=1 / 1$ ).

\section{1-Metil-2-(5-metilfurán-2-il)-4,5-difenil-1H-imidazol (369)}

A terméket a 4.14. általános szintézismódszer alapján állítottuk elő.

369: 186 mg (59\%); fehér, szilárd; Op. $137-139^{\circ} \mathrm{C} ; \mathrm{R}_{f}=0,44$ (hexán/EtOAc = 1/1).

\section{1,2-Dimetil-4,5-difenil-1 $H$-imidazol (370)}

A terméket a 4.14. általános szintézismódszer alapján állítottuk elő.

370: 172 mg (69\%); fehér, szilárd; Op. $109-110^{\circ} \mathrm{C} ; \mathrm{R}_{f}=0,17$ (hexán/EtOAc $=1 / 1$ ). 


\section{2-(terc-Butil)-1-metil-4,5-difenil-1H-imidazol (371)}

A terméket a 4.14. általános szintézismódszer alapján állítottuk elő.

371: $146 \mathrm{mg}$ (50\%); bézs, szilárd; Op. $123-124{ }^{\circ} \mathrm{C} ; \mathrm{R}_{f}=0,62$ (hexán/EtOAc $=4 / 1$ ).

\section{2-Ciklopropil-1-metil-4,5-difenil-1H-imidazol (372)}

A terméket a 4.14. általános szintézismódszer alapján állítottuk elő.

372: 160 mg (58\%); fehér, szilárd; Op. $110-111^{\circ} \mathrm{C} ; \mathrm{R}_{f}=0,24$ (hexán/EtOAc $\left.=4 / 1\right)$.

\section{2-Ciklohexil-1-metil-4,5-difenil-1H-imidazol (373)}

A terméket a 4.14. általános szintézismódszer alapján állítottuk elő.

373: 249 mg (79\%); fehér, szilárd; Op. $119-120{ }^{\circ} \mathrm{C} ; \mathrm{R}_{f}=0,58($ hexán/EtOAc $=4 / 1$ ).

\section{1,2-Diizopropil-4,5-difenil-1H-imidazol (374)}

A terméket a 4.14. általános szintézismódszer alapján állítottuk elő.

374: $72 \mathrm{mg}$ (24\%); fehér, szilárd; Op. $171-172{ }^{\circ} \mathrm{C} ; \mathrm{R}_{f}=0,51$ (hexán/EtOAc $=4 / 1$ ).

\section{1-Ciklohexil-2,4,5-trifenil-1H-imidazol (375)}

A terméket a 4.14. általános szintézismódszer alapján állítottuk elő.

375: $121 \mathrm{mg}$ (32\%); fehér, szilárd; Op. $165-166^{\circ} \mathrm{C} ; \mathrm{R}_{f}=0,81$ (hexán/EtOAc $=1 / 1$ ).

\section{1-Benzil-2-izopropil-4,5-difenil-1 $H$-imidazol (376)}

A terméket a 4.14. általános szintézismódszer alapján állítottuk elő.

376: 293 mg (83\%); fehér, szilárd; Op. $120-121^{\circ} \mathrm{C} ; \mathrm{R}_{f}=0,58$ (hexán/EtOAc $=4 / 1$ ). 


\section{7. Összefoglalás}

Szubsztituáltságuk alapján ((i) alifás, (ii) aromás és (iii) C-2-es pozícióban szubsztituálatlan) $2 \mathrm{H}$-azirineket (( \pm$)$-270a-j vegyületek) állítottunk elő három eltérő, módosított irodalmi szintézisstratégiát alkalmazva.

A kísérleti munka első részében az Ugi-Joullié-3CR $2 H$-azirinekre történő kiterjeszthetőségét vizsgáltuk az $( \pm)$-etil-3-metil-2 $H$-azirin-2-karboxilát $(( \pm)-270 a)$, terc-butilizocianid (279a) és benzoesav (280a) modellreakcióján keresztül. Miután az első kísérletek során konverziót nem tapasztaltunk, kísérletet tettünk az azirin Lewis- vagy Brønsted-sav általi aktiválására. A tesztelt katalizátorok közül a $\mathrm{ZnCl}_{2}$ bizonyult a leghatékonyabbnak, mely $71 \%$ os összesített HPLC-hozammal két $N$-acilaziridin-2-karboxamid diasztereomert eredményezett $(( \pm)-\mathbf{2 8 1}\{1\}$ transz és $( \pm)-\mathbf{2 8 2}\{1\}$ cisz, 93:7 dr). Ezt követően a katalizátormennyiség, az oldószer, a hőmérséklet és a koncentráció változtatásával meghatároztuk az optimális reakciókörülményeket (25 mol\% $\mathrm{ZnCl}_{2}$, absz. THF, 0,125 $\mathrm{M}( \pm)-\mathbf{2 7 0 a}, 55{ }^{\circ} \mathrm{C}, 4-6$ óra). Megfigyeltük, hogy a diasztereomer arányt a reakciókörülmények jelentősen nem befolyásolják.

A modellreakció karbonsav és izocianid komponenseinek szisztematikus változtatásával egy 28 tagból álló vegyületkönytárat szintetizáltunk (65. ábra). A reakcióban elektronküldő és elektronszívó szubsztituenseket tartalmazó benzoesavakon túl aralkil, heteroaromás és alifás karbonsavak, illetve alifás, benzil és aromás izocianidok egyaránt részt vettek. A reakciók magas diasztereoszelektivitással (93:7 - >99:1 dr) mentek végbe, így kizárólag a 281\{1-28\} transz fötermékeket izoláltuk (22-80\%). Megfigyeltük, hogy a reakciók hatékonyságát föként az izocianid elektronikai sajátsága határozza meg: benzil- és alifás izocianidokkal jobb izolált hozamokat értünk el, mint aromás származékokkal. Különböző $2 H$-azirineket alkalmazva a vegyületkönyvtárat tovább bővítettük (65. ábra, 281\{29-44\} és 282\{33,35,36\}: 17-70\%). Többek között megfigyeltük, hogy teljesen szubsztituált azirinek esetén a transz diasztereomer képződése jelentősen csökken (42:58-63:37 dr), melyet sztérikus okokra vezettünk vissza. Emellett megállapítottuk, hogy a reakció kiváló diasztereoszelektivitással (> 99:1 dr) aromás $2 H$ azirinekre is kiterjeszthető. Karbonsav komponensként $N$-védett aminosavakat alkalmazva megmutattuk, hogy a kifejlesztett Ugi-Joullié-3CR aziridin peptidomimetikumok szintézisére is alkalmazható (65. ábra, 281\{45-48\}: 64-82\%). Az optikailag aktív aminosav komponensek figyelemre méltó aszimmetrikus indukciót nem okoztak, a fötermékként képződő transz diasztereomereket azonban keverékként izoláltuk. A modellreakciót optikailag aktív (-)-(R)270a $2 H$-azirinnel is elvégeztük, mely során epimerizációt, enantiomerfelesleg-csökkenést nem tapasztaltunk. 


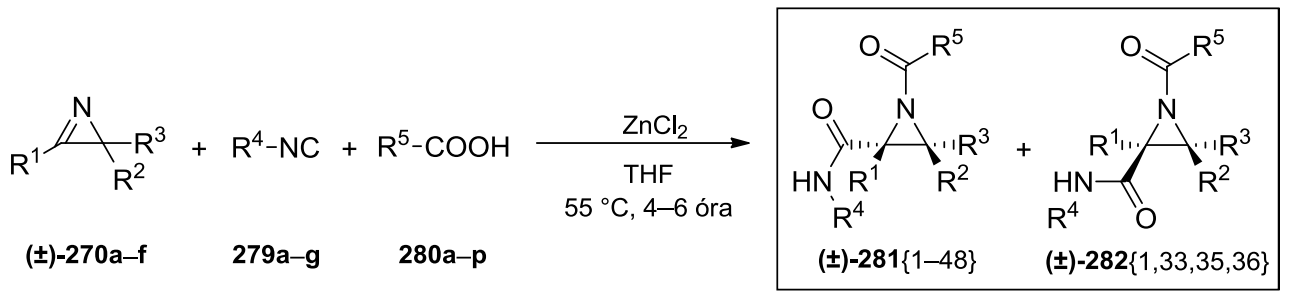

65. ábra

Néhány származékképzésen keresztül megmutattuk az előállított $N$-acilaziridinek felhasználhatóságát (66. ábra). Elsőként az etoxikarbonil funkciós csoport savamiddá történő átalakítását végeztük el. Az észter funkció alkalikus hidrolízisét követően aminok és peptidkémiai kapcsolószerek (EDC/HOBt) felhasználásával a ( \pm )-287-292 $N$-acilaziridin-2,3dikarboxamid származékokat képeztük. Emellett $N$-szubsztituálatlan aziridinek előállítására fókuszálva a $( \pm)-\mathbf{2 8 1}\{10\}$ analóg $N$-trifluoracetil-csoportját az aziridinek szakirodalmában ismeretlen módon nátrium-bórhidriddel, enyhe reakciókörülmények között eltávolítottuk $(( \pm)-$ 293). Továbbá a $( \pm)-\mathbf{2 8 1}\{1\}$ vegyületet $\operatorname{Sc}(\mathrm{OTf})_{3}$ jelenlétében vízzel a $( \pm)$-298 $\beta$-hidroxi- $\alpha$ aminosav származékká alakítottuk. A gyürünyitás teljes regioszelektivitással egységes terméket eredményezett, azonban nem sikerült meghatároznunk, hogy melyik diasztereomer képződött.
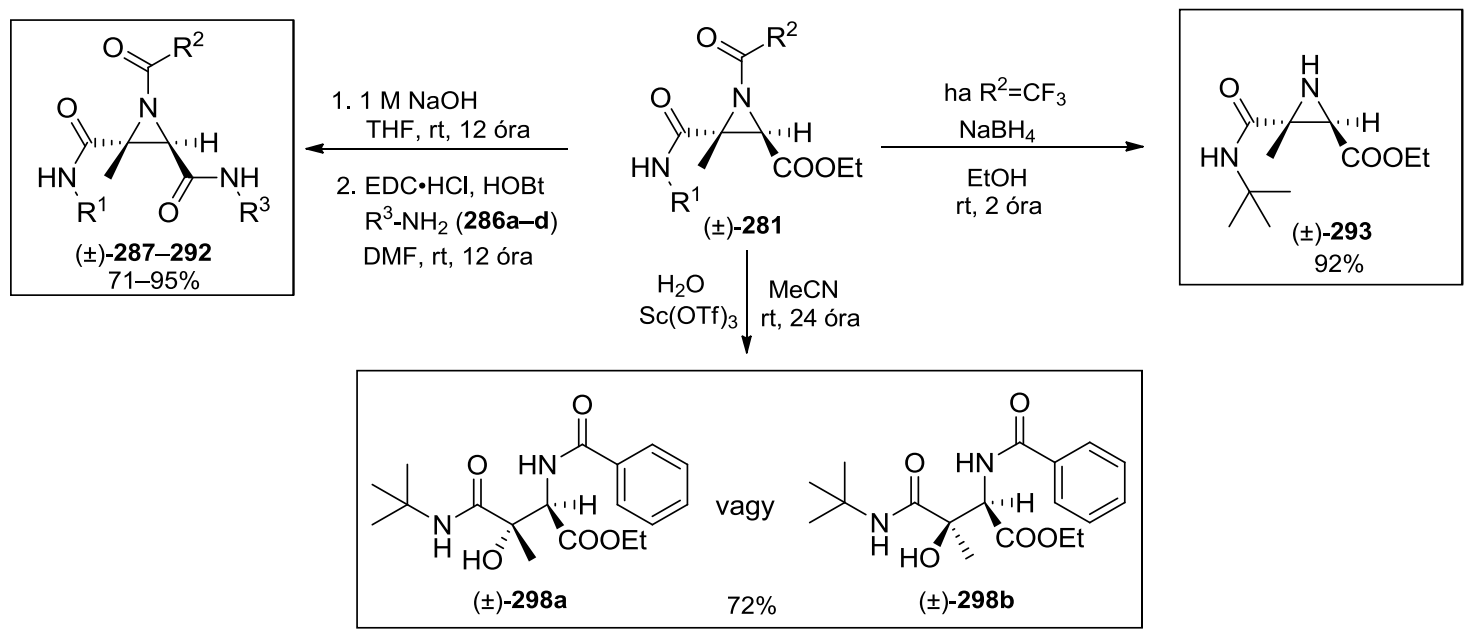

66. ábra

Végül a $( \pm)-\mathbf{2 8 1}\{1\}$ és $( \pm)-\mathbf{2 8 2}\{1\}$ diasztereomerekből kiindulva Heine-reakcióval a transz-( \pm -294 és cisz-( \pm )-295 oxazolinokat alakítottuk ki (67. ábra). Váratlan módon $\mathrm{BF}_{3} \cdot 2 \mathrm{H}_{2} \mathrm{O}$ alkalmazásával a gyürü felnyílása helyett szintúgy oxazolinok képződését tapasztaltuk, azonban a reakció az előző termékek regioizomeréhez, a transz-( $( \pm)-296$ és cisz- $( \pm)-297$ oxazolinok keletkezéséhez vezetett. A reakciók teljes regioszelektivitással, a konfiguráció retenciójával mentek végbe, epimerizációt egyik szintézismódszer során sem tapasztaltunk. 

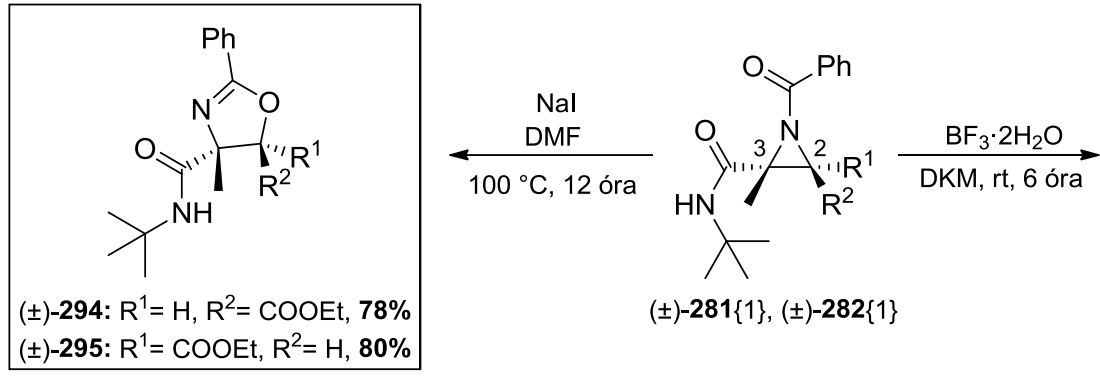

$( \pm)-281\{1\},( \pm)-282\{1\}$

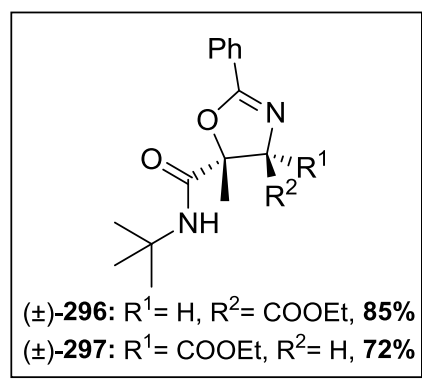

67. ábra

Az Avidin Kft. biológus munkatársai az előállított $( \pm)-281\{1-48\}$ és $( \pm)-287-292 N$ acilaziridin származékokat több sejtvonalon (A549, MCF7, HL60, 3T3) in vitro citotoxicitási vizsgálatoknak vetették alá, azonban a vegyületek többsége a tesztelt koncentrációtartományban (1-30 $\mu \mathrm{M})$ inaktívnak bizonyult vagy csekély citotoxikus hatást mutatott (IC50 > $20 \mu \mathrm{M})$.

A kísérleti munka második részében az izatin (299a), D-(-)-2-fenilglicin (300a) és $( \pm)$ etil-3-metil-2H-azirin-2-karboxilát $(( \pm)-\mathbf{2 7 0 a})$ háromkomponensü modellreakcióján keresztül a $2 H$-azirinek és in situ képzett oxindol-alapú azometin-ilidek 1,3-dipoláris cikloaddíciójának lehetőségét tanulmányoztuk (68. ábra). Miután a szobahőmérsékleten, poláris közegben végzett első kísérletek két diasztereomer endo cikloaddukt spirooxindol-imidazolidin $(( \pm)$-301a és $( \pm)$ 301b) képződését igazolták, különböző oldószereket alkalmazva, a koncentrációt változtatva, illetve a hőmérsékletet $60^{\circ} \mathrm{C}$-ra emelve meghatároztuk az optimális reakciókörülményeket (absz. DMSO, 0,25 M ( \pm )-270a, $60{ }^{\circ} \mathrm{C}, 8$ óra; 72\% összesített HPLC hozam, 92:8 dr).

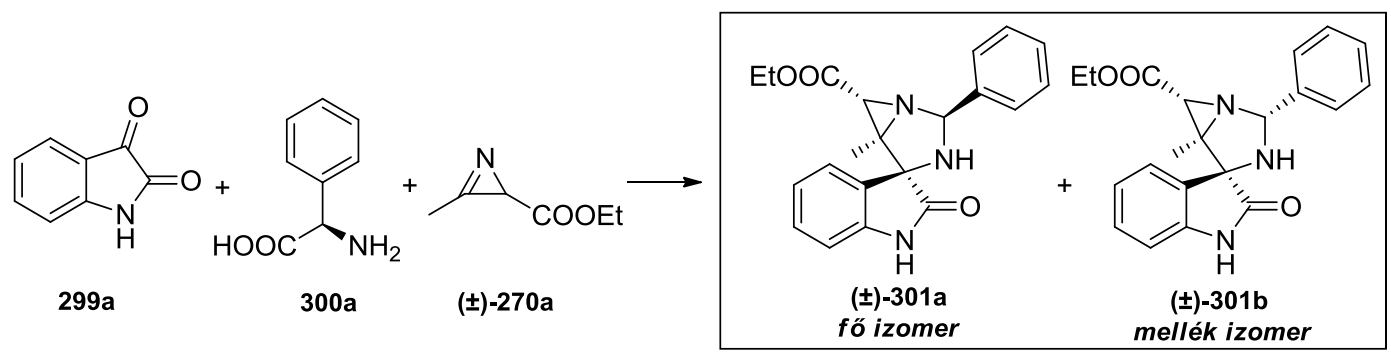

68. ábra

A ( $( \pm)$-301a izolálását $(65 \%)$ követően a modellreakció izatin, majd $2 H$-azirin komponensének szisztematikus változtatásával egy 15 tagból álló vegyületkönyvtárat hoztunk létre (69. ábra). A reakciók közepes-jó diaszteroszelektivitással (63:37-92:8 dr) mentek végbe, kizárólag a fő izomert izoláltuk (( \pm$)-302 a-316 a: ~ 32-78 \%)$. A kísérletek során jelentős szubsztituenshatást nem tapasztaltunk, a reakcióban elektronban gazdag és elektronban szegény izatinok és aromás azirinek egyaránt részt vettek. A $( \pm)$-270f 3-benzilazirin $\left(\mathrm{R}^{5}=\mathrm{Bn}\right)$ alkalmazásakor a minor diasztereomer nagyobb arányú képződését figyeltük meg $(( \pm)-\mathbf{3 1 2 a}$, 63:37 dr), melyet a benzilcsoport és az azometin-ilid fenilcsoportja között fellépö $\pi-\pi$ 
kölcsönhatással magyaráztunk. Az eljárás hatékonyságát ezt követően különböző $\alpha$ aminosavakkal teszteltük, izatin (299a) és ( $( \pm)$-270a azirin komponensek mellett. A reakció változatos alifás, aromás és aralkil oldalláncokkal szubsztituált aminosavakon túl trifunkciós aminosavakkal is kompatibilisnek bizonyult $(( \pm)-317 \mathbf{a}-\mathbf{3 2 7 a}: 37-81 \%, 76: 24-90: 10 \mathrm{dr})$, azonban az aliciklusos L-prolin rendkívül alacsony termelést eredményezett $(( \pm)-328 a$ : $11 \%$, 89:11 dr). Az aminosav kémiai minősége a reakció diasztereoszelektivitását jelentősen nem befolyásolta. Végül a ( \pm -328a vegyület szintézisének reakciókörülményeit újravizsgáltuk, majd az L-prolinra optimalizált új protokollal (IPA, 0,075 M 300m, 3 ekv. 2H-azirin, rt, 24 óra) többnyire magas diasztereoszelektivitással (71:29-95:5 dr) további öt analógot szintetizáltunk (69. ábra, ( $( \pm$ )-328a-333a: $33-68 \%)$.

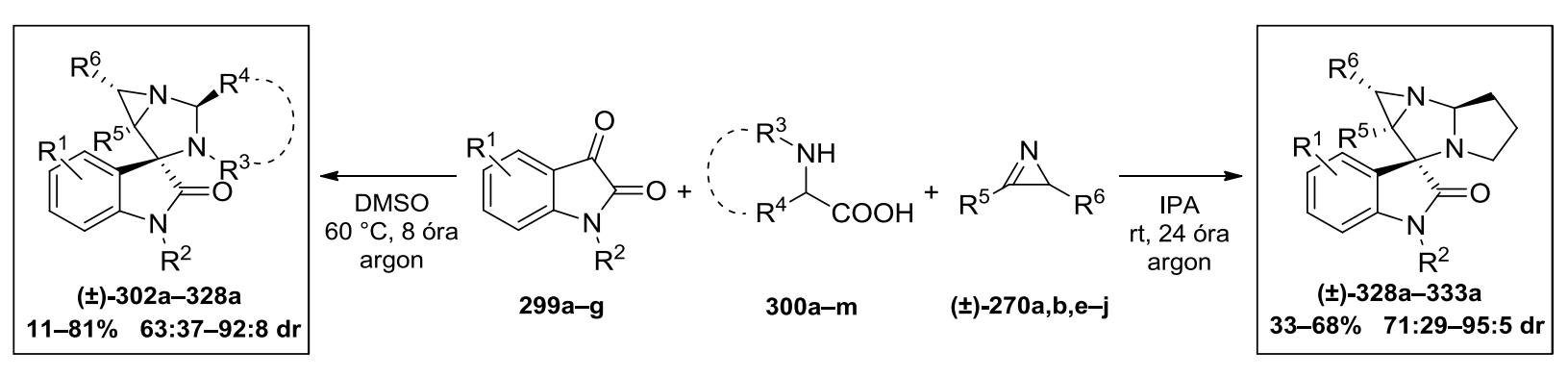

69. ábra

A kísérleti és analitikai eredmények alapján a reakció mechanizmusára javaslatot tettünk. Az előállított spirooxindol-imidazolidin származékokat az Avidin Kft. biológus munkatársai több sejtvonalon (A549, MCF7, 3T3) in vitro citotoxicitási vizsgálatoknak vetették alá, azonban a vegyületek jelentős tumorellenes hatást nem mutattak.

A kísérleti munka harmadik részében a $2 H$-azirinek és nitronok közötti 1,3-dipoláris cikloaddíció megvalósíthatóságát tanulmányoztuk. A ( \pm )-270a azirin és a 334a nitron Brønstedvagy Lewis-sav katalízist igénylő reakciója azonban a várt 335 cikloaddukt helyett a 336 tetraszubsztituált imidazol képződéséhez vezetett (70. ábra). Egy újfajta imidazolszintézis kidolgozására fókuszálva a reakciókörülményeket különböző savkatalizátorok és oldószerek tesztelésével, valamint az azirin és a katalizátor mennyiségének változtatásával optimalizáltuk. A legmagasabb HPLC hozamot (78\%) TFA katalizátorral, vízmentes acetonitrilben, $60{ }^{\circ} \mathrm{C}$-on értük el.

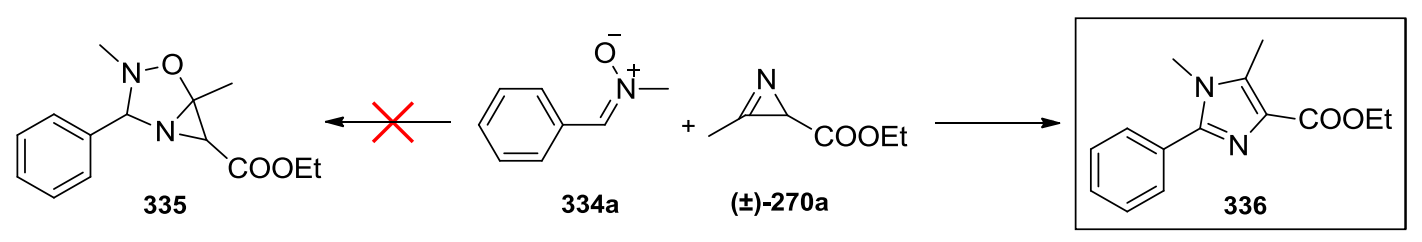

70. ábra 
Az optimális reakciókörülmények (1,5 ekv. ( \pm -270a, 10 mol\% TFA, absz. MeCN, 60 ${ }^{\circ} \mathrm{C}, 6$ óra) beállítását követően a $( \pm)$-270a $2 H$-azirint különböző nitronokkal reagáltattuk (71. ábra). A reakcióban elektronban szegény és gazdag $C$-fenil $N$-metil-nitronokon túl $C$ heteroaromás és $C$-alifás $N$-metil-nitronok is részt vettek (336-348: 41-82\%). A reakciót emellett $C$-fenil és $C$-alkil $N$-(ar)alkil- és $N$-alifás-nitronokra is kiterjesztettük (349-353: $37-$ 71\%), mellyel a módszer széleskörü alkalmazhatóságát bizonyítottuk. A kísérletek során megfigyeltük, hogy a nitron szubsztituenseinek növekvő térigényével párhuzamosan általában alacsonyabb hozamok érhetők el.

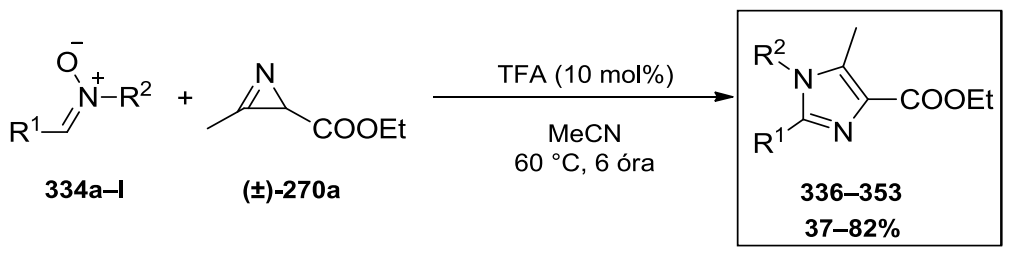

71. ábra

Különböző azirinek alkalmazhatóságát is vizsgáltuk, melyeket egy $C$-aromás $\left(\mathrm{R}^{1}=\right.$ fenil $)$, illetve egy $C$-alifás $\left(\mathrm{R}^{1}=i\right.$-Pr) $N$-metilnitronnal reagáltattunk (72. ábra). Megmutattuk, hogy az eljárás 4,5-diaril-imidazolok szintézisére is alkalmas, melyeket a 2,3-diarilazirinek elektronikus tulajdonságától függetlenül jó termelésekkel állítottunk elő (355-358, 362-365: 67-79\%). Ezzel szemben benzil-szubsztituált azirin $\left(( \pm)\right.$-270f, $\mathrm{R}^{3}=\mathrm{Bn}, \mathrm{R}^{4}=$ fenil) alkalmazásakor alacsonyabb izolált hozamokat értünk el (359: 45\% és 366: 57\%), míg a monoszubsztituált $( \pm)-270 j$ azirin $\left(\mathrm{R}^{3}=\right.$ fenil, $\left.\mathrm{R}^{4}=\mathrm{H}\right)$ komplex reakcióelegyeket és nyomnyi mennyiségü imidazolokat eredményezett. A módszer általánosságának alaposabb vizsgálata érdekében a $( \pm)$-270e aromás azirin reaktivitását néhány másik, korábban már alkalmazott nitronnal is teszteltük (72. ábra, 368-376: 24-83\%). Ezúttal is megfigyeltük, hogy a nagy térkitöltésü csoporttal szubsztituált nitronok általában alacsonyabb hozamokat eredményeznek.

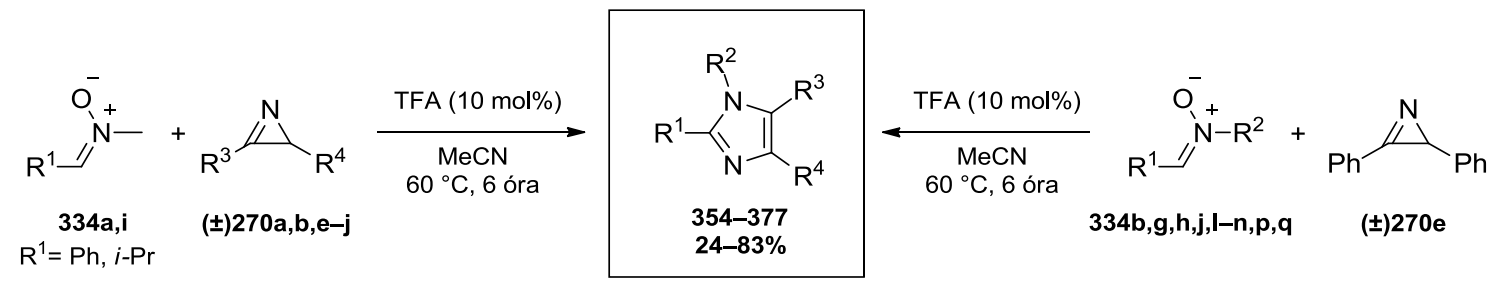

72. ábra

A termékek szerkezetét egy- és kétdimenziós NMR technikák, valamint tömegspektrometria alkalmazásával igazoltuk. A 301a és 328a spirooxindol-imidazolidin származék szerkezetét emellett röntgenkrisztallográfiás felvétel is alátámasztotta. 


\section{Summary}

In consideration of the substitution pattern ((i) aliphatic, (ii) aromatic, and (iii) unsubstituted at position $\mathrm{C}$-2), $2 \mathrm{H}$-azirines were prepared by applying three different, modified known synthetic strategies (compounds $( \pm)-\mathbf{2 7 0 a}-\mathbf{j})$.

In the first part of the experimental work, the extendibility of the Ugi-Joullie threecomponent reaction to $2 \mathrm{H}$-azirines was investigated through a model reaction of ( \pm )-ethyl 3methyl-2H-azirine-2-carboxylate $(( \pm)$-270a), tert-butyl isocyanide (279a) and benzoic acid (280a). Since no conversion was observed in the first experiments, attempts have been made to activate the azirine by Lewis- or Brønsted acid catalysis. Among the catalyst tested, $\mathrm{ZnCl}_{2}$ proved to be the most efficient, providing two $\mathrm{N}$-acylaziridine-2-carboxamide diastereomers in $71 \%$ combined HPLC yield (products trans- $( \pm)-\mathbf{2 8 1}\{1\}$ and cis- $( \pm)-\mathbf{2 8 2}\{1\}, 93: 7 \mathrm{dr})$. By varying the catalyst loadings, solvent, temperature, and concentration, the optimal reaction conditions were set (25 mol\% $\mathrm{ZnCl}_{2}$, abs. THF, $0.125 \mathrm{M}( \pm)$-270a, $55^{\circ} \mathrm{C}$, 4-6 h). It was observed that the reaction conditions have no significant influence on the diastereomeric ratios.

Systematically varying the carboxylic acid and isocyanide components of the model reaction, a 28-membered compound library was synthesized (Scheme 73). Benzoic acids bearing electron-donating and electron-withdrawing substituents as well as aralkyl, heteroaromatic, and aliphatic carboxylic acids were compatible with the reaction. Aliphatic, benzyl, and aromatic isocyanides could be also subjected to the reaction. Since the reactions proceeded with high diastereoselectivities (93:7 - >99:1 dr), the major trans products $\mathbf{2 8 1}\{1-28\}$ were isolated exclusively (22-80\%). It was observed that the efficiency of the transformation is mainly affected by the electronic nature of the isocyanide. Benzyl and aliphatic isocyanides provided better isolated yields than aromatic derivatives. By employing various $2 H$-azirines, the $N$-acylazirdine2-carboxamide library was further extended (Scheme 73, 281 \{29-44\} and 282\{33,35,36\}: 17$70 \%$ ). Among others it was observed that the formation of the trans diastereomer is significantly decreased due to steric effects (42:58-63:37), if fully substituted azirines are applied. Besides, we found that the reaction could also be extended to aromatic $2 H$-azirines with excellent diastereoselectivities (> 99:1 dr). By employing $N$-protected amino acids as carboxylic acid components, the feasibility of the developed Ugi-Joullié reaction for the synthesis of aziridine peptidomimetics was demonstrated (Scheme 73, 281\{45-48\}: 64-82\%). The optically active amino acid components did not result in significant asymmetric induction; however, the major trans products were isolated as diastereomeric mixtures. The model reaction was also performed 
with optically active $2 H$-azirine (-)-(R)-270a. Epimerization or decrease in enantiomeric excess was not observed.

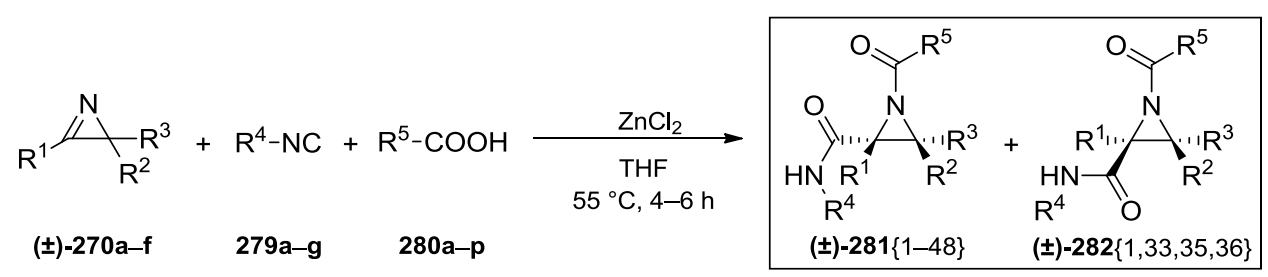

Scheme 73.

The utility of the synthesized $N$-acylaziridines was investigated through several derivatizations (Scheme 74). First, the transformation of the ethoxycarbonyl functional group to carboxamide was performed. $N$-acylaziridine-2,3-dicarboxamide derivatives $( \pm)$-287-292 were prepared by the alkaline hydrolysis of the ester group followed by the application of amines and peptide coupling reagents $(\mathrm{EDC} / \mathrm{HOBt})$. Focusing on the synthesis of $N$-unsubstituted aziridines, the $N$-trifluoroacetyl group of compound $( \pm)-\mathbf{2 8 1}\{10\}$ was removed with sodium borohydride under mild conditions $(( \pm)-\mathbf{2 9 3})$, representing an unprecedented deprotection in the chemistry of aziridines. Compound $( \pm)-\mathbf{2 8 1}\{1\}$ was transformed to $\beta$-hydroxy- $\alpha$-amino acid derivative $( \pm)$ 298 with water in the presence of $\operatorname{Sc}(\mathrm{OTf})_{3}$. Ring opening resulted in a single product with complete regioselectivity, although the diastereomeric outcome of the reaction could not be determined.
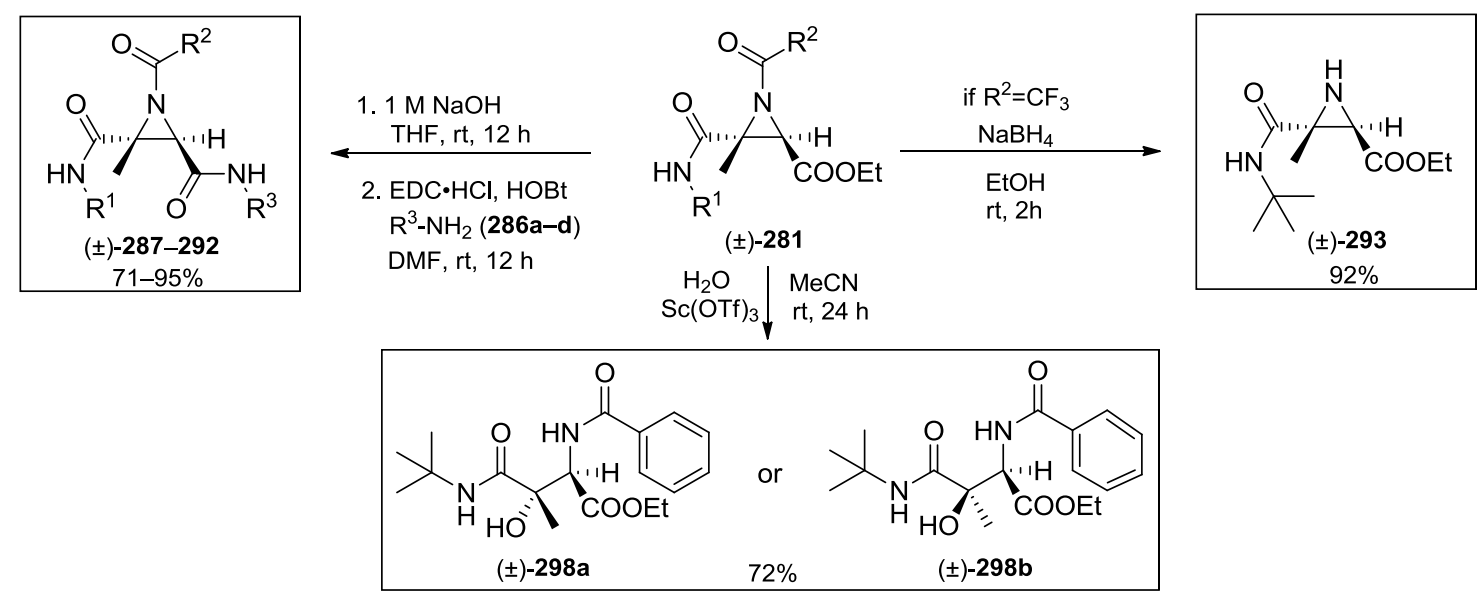

Scheme 74.

Finally, starting from $( \pm)-\mathbf{2 8 1}\{1\}$ and $( \pm)-282\{1\}$ diastereomers, trans- $( \pm)-294$ and cis295 oxazolines were synthesized via Heine reaction (Scheme 75). Unexpectedly, reactions performed with $\mathrm{BF}_{3} \cdot 2 \mathrm{H}_{2} \mathrm{O}$ led to oxazolines as well, though with inversed regioselectivity (products trans- $( \pm)-296$ and cis-( $( \pm)-297)$, instead of ring opening. The transformations were accomplished with complete regioselectivity and retention of configuration. None of the synthetic methods resulted in epimerization. 


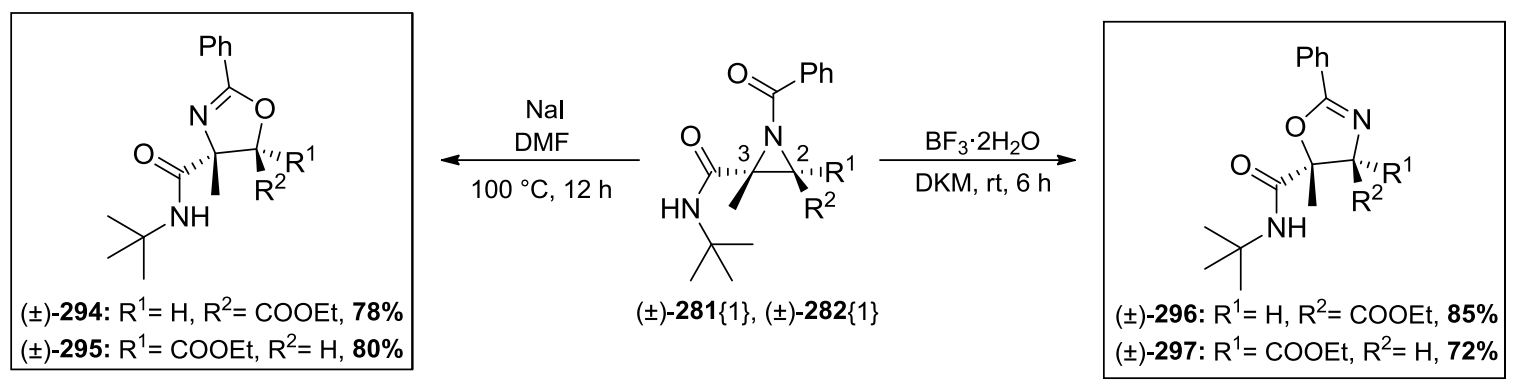

Scheme 75.

The synthesized N-acylaziridine derivatives $( \pm)-\mathbf{2 8 1}\{1-48\}$ and $( \pm)-\mathbf{2 8 7}-\mathbf{2 9 2}$ were submitted to in vitro cytotoxicity tests at Avidin Ltd. on different tumorous cell lines (A549, MCF7, HL60, 3T3), however, most of the compounds proved to be inactive in the tested range (1-30 $\mu \mathrm{M})$, or showed insignificant cytotoxic activity (IC50 > $20 \mu \mathrm{M}$ ).

In the second part of the experimental work, the feasibility of the 1,3-dipolar cycloaddition of $2 \mathrm{H}$-azirines and in situ generated oxindole-based azomethine ylides was investigated through a model three-component reaction between isatin (299a), D-(-)-2phenylglycine (300a), and ( \pm )-ethyl 3-methyl-2H-azirine-2-carboxylate (( \pm$)$-270a) (Scheme 76). The first experiments at room temperature in polar solvents led to the formation of two diastereomeric spirooxindole-imidazolidine endo cycloadducts $(( \pm)-301 \mathbf{a}$ and $( \pm)-\mathbf{3 0 1 b})$. The reaction conditions were optimized by applying different solvents, varying the concentration and elevating the temperature to $60{ }^{\circ} \mathrm{C}$, (abs. DMSO, $0.25 \mathrm{M}( \pm)-\mathbf{2 7 0 a}, 60{ }^{\circ} \mathrm{C}, 8 \mathrm{~h} ; 72 \%$ combined HPLC yield, 92:8 dr).

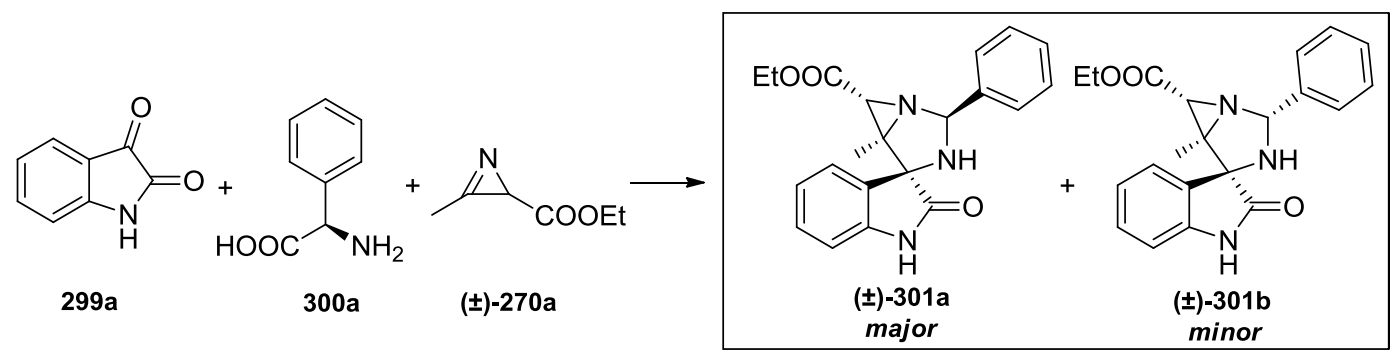

Scheme 76.

Following the the isolation of $( \pm)$-301a $(65 \%)$, systematically varying the isatin, then the $2 H$ azirine components of the model reaction, a 15-membered compound library was synthesized (Scheme 77). The reactions proceeded with moderate to good diastereoselectivity (63:37-92:8 dr); therefore, the major isomer was isolated exclusively (( \pm$)-302 a-316 a: 32-78 \%)$. Remarkable substituent effect was not observed, and both electron-rich and electron-deficient isatins and aromatic azirines were tolerated. Application of 3-benzylazirine $( \pm)-\mathbf{2 7 0 f}\left(R^{5}=B n\right)$ resulted in the increased formation of the minor diastereomer $(( \pm)-\mathbf{3 1 2 a}, 63: 37 \mathrm{dr})$, which was accounted for 
by the $\pi-\pi$ interaction between the benzyl moiety and the phenyl group of the azomethine ylide. Using isatin (299a) and azirine ( \pm )-270a as inputs, the efficiency of the protocol was evaluated with a range of $\alpha$-amino acids thereafter. Amino acids bearing various aliphatic, aromatic, and aralkyl side chains as well as trifunctional amino acids were proved to be compatible with the reaction (( \pm -317a-327a: 37-81\%, 76:24-90:10 dr); however, alicyclic L-proline resulted in remarkably low yield $(( \pm)-328 a: 11 \%, 89: 11 \mathrm{dr})$. The nature of the amino acid component had no significant influence on the diastereoselectivity. Finally, the reaction conditions for the synthesis of compound ( \pm )-328a was reinvestigated. By applying the reoptimized protocol (IPA, $0.075 \mathrm{M} 300 \mathrm{~m}, 3$ equiv. of $2 \mathrm{H}$-azirine, $\mathrm{rt}, 24 \mathrm{~h}$ ), five more spirooxindole-imidazolidine derivatives were synthesized $(( \pm)-328 a-333 a: 33-68 \%)$ mostly with high diastereoselectivities (71:29-95:5 dr) (Scheme 77).
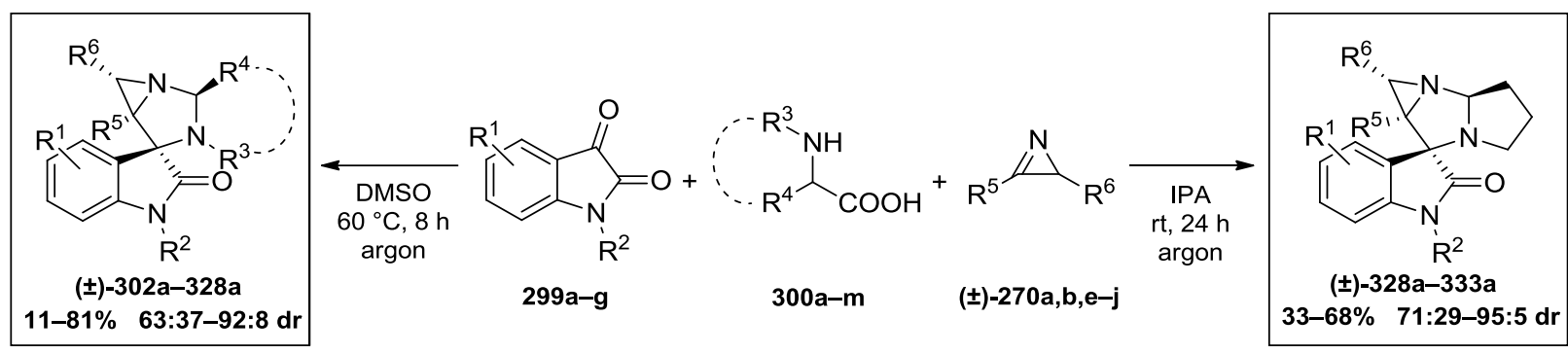

Scheme 77.

On the basis of the experimental and analytical results, a plausible reaction mechanism was proposed. The synthesized spirooxindole-imidazolidine derivatives were submitted to in vitro cytotoxicity tests at Avidin Ltd. on different tumorous cell lines (A549, MCF7, 3T3), however, the compounds showed insignificant cytotoxic activity.

In the third part of the experimental work, feasibility of the 1,3-dipolar cycloaddition between $2 \mathrm{H}$-azirines and nitrones was investigated. The Brønsted or Lewis acid catalyzed reaction of azirine $( \pm)-\mathbf{2 7 0 a}$ and nitrone $\mathbf{3 3 4 a}$ led to the formation of tetrasubstituted imidazole 336 instead of the expected cycloadduct 335 (Scheme 78). Focusing on the elaboration of a new imidazole synthesis, the optimal reaction conditions were set by applying different acid catalysts and solvents, and varying the azirine and catalyst loading. The highest HPLC yield (78\%) was achieved with TFA as catalyst in dry acetonitrile at $60^{\circ} \mathrm{C}$.

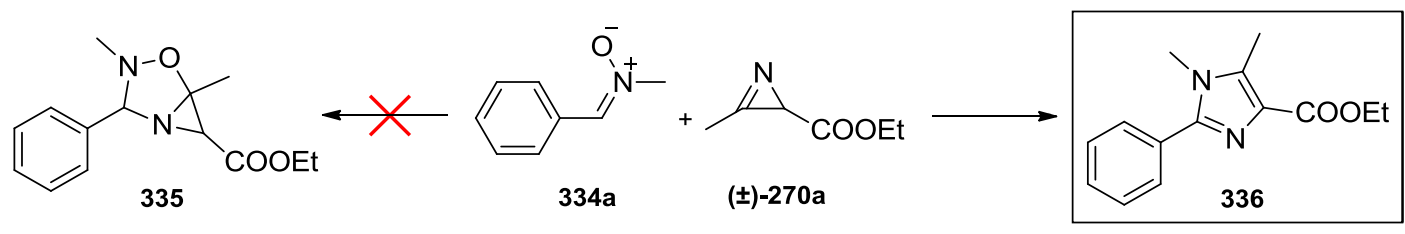

Scheme 78. 
With the optimized conditions in hand (1.5 equiv. of $( \pm)-\mathbf{2 7 0 a}, 10 \mathrm{~mol} \%$ TFA, abs. $\left.\mathrm{MeCN}, 60^{\circ} \mathrm{C}, 6 \mathrm{~h}\right), 2 \mathrm{H}$-azirine $( \pm)-\mathbf{2 7 0 a}$ was reacted with a range of nitrones (Scheme 79$)$ ). Both electron-rich and electron-poor $C$-phenyl $N$-methylnitrones as well as $C$-heteroaromatic and $C$ aliphatic $N$-methylnitrones could be subjected to the reaction (336-348: $41-82 \%)$. The reaction was also extended to $C$-phenyl and $C$-alkyl $N$-(aryl)alkyl and $N$-aliphatic nitrones (349-353: 37$71 \%$ ), demonstrating the generality of the method. It was found that the increase in the steric demand of the nitrone subtituents generally resulted in lower isolated yields.

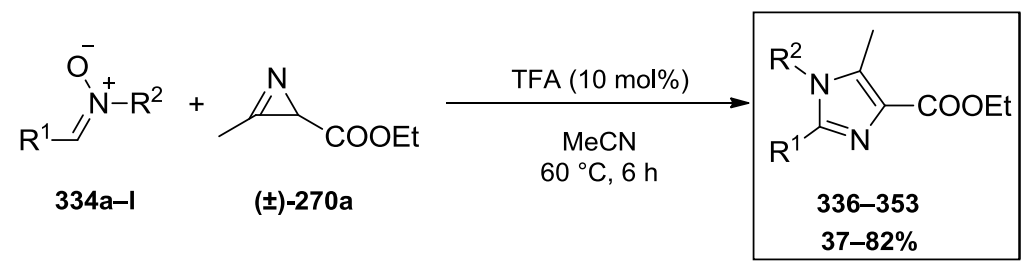

Scheme 79.

The applicability of different azirines was investigated, using both a $C$-aromatic $\left(\mathrm{R}^{1}=\right.$ phenyl) and a $C$-aliphatic $\left(\mathrm{R}^{1}=i\right.$-Pr) $N$-methylnitrone as reaction partners (Scheme 80$)$. The method also enabled access to 4,5-diarylimidazoles affording good yields (355-358, 362-365: 67-79\%) regardless of the electronic nature of the 2,3-diarylazirine. In contrast, lower isolated yields (359: $45 \%$ and 366: $57 \%$ ) were achieved if benzyl-substituted azirine $\left(( \pm)-\mathbf{2 7 0 f}, \mathrm{R}^{3}=\mathrm{Bn}\right.$, $\mathrm{R}^{4}=$ phenyl) was employed, while monosubstituted azirine $( \pm)-\mathbf{2 7 0} \mathbf{j}\left(\mathrm{R}^{3}=\right.$ phenyl, $\left.\mathrm{R}^{4}=\mathrm{H}\right)$ led to complex reaction mixtures and only trace amounts of imidazoles. For a thorough investigation of the generality of the method, the reactivity of aromatic azirine $( \pm)-270 \mathrm{e}$ toward some of the nitrones applied previously was also evaluated (Scheme 80, 368-376: 24-83\%). Nitrones bearing sterically more demanding substituents generally resulted in lower yields.

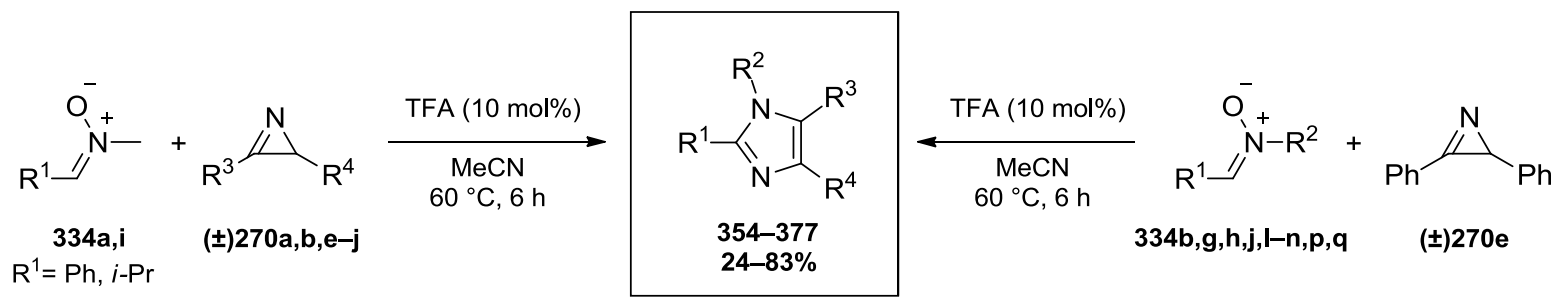

Scheme 80.

The molecular structures of products were determined by one- and two-dimensional NMR techniques combined with mass spectrometric measurements. Moreover, the structure elucidation of spirooxindole-imidazolidine derivatives 301a and 328a was also supported by Xray diffraction. 


\section{Irodalomjegyzék}

1. A. Padwa, Comprehensive Heterocyclic Chemistry III: Volume 1: Three-membered Heterocycles, together with all Fused Systems containing a Three-membered Heterocyclic Ring: 1.01 - Aziridines and Azirines: Monocyclic; Elsevier Science, 2008.

2. F. Palacios, A. M. O. de Retana, E. M. de Marigorta, J. M. de los Santos, Org. Prep. Proced. Int. 2002, 34, 219-269.

3. F. Palacios, A. M. O. de Retana, E. M. de Marigorta, J. M. de los Santos, Eur. J. Org. Chem. 2001, 2401-2414.

4. A. F. Khlebnikov, M. S. Novikov, Tetrahedron 2013, 69, 3363-3401.

5. A. Padwa, Adv. Heterocycl. Chem. 2010, 99, 1-31.

6. M. J. Alves, F. T. Costa, Heterocyclic Targets in Advanced Organic Synthesis; 2H-Azirines as electrophiles; Research Signpost, Kerala, India, 2011.

7. L. Degennaro, P. Trinchera, R. Luisi, Chem. Rev. 2014, 114, 7881-7929.

8. P. Lu, Tetrahedron 2010, 66, 2549-2560.

9. S. Stankovic, M. D’hooghe, S. Catak, H. Eum, M. Waroquier, V. V. Speybroeck, N. De Kimpe, H.-J. Ha, Chem. Soc. Rev. 2012, 41, 643-665.

10. A. L. Cardoso, T. M. V. D. Pinho e Melo, Eur. J. Org. Chem. 2012, 6479-6501.

11. W. MCoull, F. A. Davis, Synthesis 2000, 1347-1365.

12. H. Pellissier, Adv. Synth. Catal. 2014, 356, 1899-1935.

13. J. B. Sweeney, Chem. Soc. Rev. 2002, 31, 247-258.

14. V. M. Dembitsky, A. O. Trent'ev, D. O. Levitsky, Natural Products; Aziridine Alkaloids: Origin, Chemistry and Activity; Springer, Berlin, Heidelberg, 2013.

15. J. Zhu, H. Bienaymé, Multicomponent Reactions; Wiley-VCH: Weinheim, 2005.

16. R. V. A. Orru, E. Ruijter, Synthesis of Heterocycles via Multicomponent Reactions I, Topics in Heterocyclic Chemistry; Springer-Verlag, Berlin, Heidelberg, 2010.

17. J. E. Biggs-Houck, A. Younai, J. T. Shaw, Curr. Opin. Chem. Biol. 2004, 14, 371-382.

18. S. R. Wilson, A. W. Czarnik, Combinatorial Chemistry: Synthesis and Application; WileyVCH, Weinheim, 1997.

19. I. Akritopoulou-Zanze, Curr. Opin. Chem. Biol. 2008, 12, 324-331.

20. I. Ugi, R. Meyr, U. Fetzer, C. Steinbrückner, Angew. Chem. 1959, 71, 386.

21. A. Dömling, Chem. Rev. 2006, 106, 17-89.

22. N. Chéron, R. Ramozzi, L. El Kaïm, L. Grimaud, P. Fleurat-Lessard, J. Org. Chem. 2012, 77, 1361-1366. 
23. T. Godet, Y. Bonvin, G. Vincent, D. Merle, A. Thozet, M. A. Ciufolini, Org. Lett. 2004, 6, 3281-3284.

24. B. O. Okandeji, J. R. Gordon, J. K. Sello, J. Org. Chem. 2008, 73, 5595-5597.

25. Q. Wang, D.-X. Wang, M.-X. Wang, J. Zhu, Acc. Chem. Res. 2018, 51, 1290-1300.

26. J. Zhang, P. Yu, S.-Y. Li, H. Sun, S.-H. Xiang, J. Wang, K. N. Houk, B. Tan, Science 2018, 361 , eaas8707.

27. S. Shaabani, A. Dömling, Angew. Chem. Int. Ed. 2018, 57, 2-5.

28. D. J. Ramón, M. Yus, Angew. Chem. Int. Ed. 2005, 44, 1602-1634.

29. C. de Graaff, E. Ruijter, R. V. A. Orru, Chem. Soc. Rev. 2012, 41, 3969-4009.

30. S. S. van Berkel, B. G. M. Bögels, M. A. Wijdeven, B. Westermann, F. P. J. T. Rutjes, Eur. J. Org. Chem. 2012, 19, 3543-3559.

31. I. Ugi, K. Offermann, Angew. Chem. Int. Ed. 1963, 2, 624.

32. G. Eberle, I. Ugi, Angew. Chem. Int. Ed. 1976, 15, 492.

33. D. Marquarding, P. Hoffmann, H. Heitzer, I. Ugi, J. Am. Chem. Soc. 1970, 92, 1969- 1971.

34. I. Ugi, K. Offermann, H. Herlinger, D. Marquarding, Liebigs Ann.Chem. 1967, 709, 1128.

35. H. Kunz, W. Pfrengle, J. Am. Chem. Soc. 1988, 110, 651-652.

36. T. Yamada, N. Motoyama, T. Taniguchi, Y. Kazuta, T. Miyazawa, S. Kuwata, K. Matsumoto, M. Sugiura, Chem. Lett. 1987, 16, 723-726.

37. I. Kanizsai, Z. Szakonyi, R. Sillanpää, F. Fülöp, Tetrahedron Lett. 2006, 47, 9113-9116.

38. M. C. Pirrung, K. D. Sarma, J. Am. Chem. Soc. 2004, 126, 444-445.

39. M. C. Pirrung, K. D. Sarma, Synlett 2004, 1425-1427.

40. Sz. Gedey, J. Van der Eycken, F. Fülöp, Org. Lett. 2002, 4, 1967-1969.

41. H. P. Isenring, W. Hofheinz, Synthesis, 1981, 385-387.

42. I. Kanizsai, Sz. Gyónfalvi, Zs. Szakonyi, R. Sillanpää, F. Fülöp, Green Chem. 2007, 9, 357-360.

43. A. Demharter, W. Hörl, E. Herdtweck, I. Ugi, Angew. Chem. Int. Ed. 1996, 35, 173-175.

44. C. B. Gilley, M. J. Buller, Y. Kobayashi, Synlett 2008, 2249-2252.

45. C. B. Gilley, M. J. Buller, Y. Kobayashi, Org. Lett. 2007, 9, 3631-3634.

46. C. B. Gilley, M. J. Buller, Y. Kobayashi, J. Org. Chem. 2008, 73, 4198-4204.

47. L. El Kaim, L. Grimaud, Tetrahedron 2009, 65, 2153-2171.

48. R. F. Nutt, M. M. Joullié, J. Am. Chem. Soc. 1982, 104, 5852-5853.

49. M. M. Bowers, P. Caroll, M. M. Joullié, J. Chem. Soc., Perkin Trans. I. 1989, 857-865.

50. V. G. Nenajdenko, A. V. Gulevich, E. S. Balenkova, Tetrahedron 2006, 62, 5922-5930. 
51. A. V. Gulevich, N. E. Shevchenko, E. S. Balenkova, G.-V. Röschenthaler, V. G. Nenajdenko, Synlett 2009, 403-406.

52. V. Cerulli, L. Banfi, A. Basso, V. Rocca, R. Riva, Org. Biomol. Chem. 2012, 10, 12551274 .

53. A. Znabet, E. Ruijter, F. J J. de Kanter, V. Köhler, M. Helliwell, N. J. Turner, R. V. A. Orru, Angew. Chem. Int. Ed. 2010, 49, 5289-5292.

54. K. Katayama, K. Nakagawa, H. Takeda, A. Matsuda, S. Ichikawa, Org. Lett. 2014, 16, $428-431$.

55. W. Maison, A. Lützen, M. Kosten, I. Schlemminger, O. Westerhoff, J. Martens, J. Chem. Soc., Perkin Trans. I. 1999, 3515-3525.

56. L. Banfi, A. Basso, V. Cerulli, V. Rocca, R. Riva, Beilstein J. Org. Chem. 2011, 7, 976979.

57. J. Iwanejko, E. Wojaczyńska, Org. Biomol. Chem. 2018, 16, 7296-7314.

58. A. Katsuyama, A. Matsuda, S. Ichikawa, Org. Lett. 2016, 18, 2552-2555.

59. A. Znabet, M. M. Polak, E. Janssen, F. J. J. de Kanter, N. J. Turner, R. V. A. Orru, E. Ruijter, Chem. Commun. 2010, 46, 7918-7920.

60. K. M. Bonger, T. Wennekes, D. V. Filippov, G. Lodder, G. A. van der Marel, H. S. Overkleeft, Eur. J. Org. Chem. 2008, 3678-3688.

61. K. M. Bonger, T. Wennekes, S. V. P. de Lavoir, D. Esposito, R. J. B. H. N. van den Berg, R. E. J. N. Litjens, G. A. van der Marel, H. S. Overkleeft, QSAR Comb. Sci. 2006, 25, 491503.

62. E. R. van Rijssel, T. P. M. Goumans, G. Lodder, H. S. Overkleeft, G. A. van der Marel, J. D. C. Codée. Org. Lett. 2013, 15, 3026-3029.

63. H.-H. Otto, T. Schirmeister, Chem. Rev. 1997, 97, 133-171.

64. J. C. Powers, J. L. Asgian, Ö. D. Ekici, K. E. James, Chem. Rev. 2002, 102, 4639-4750.

65. R. Vicik, M. Busemann, K. Baumann, T. Schirmeister, Curr. Top. Med. Chem. 2006, 6, 331-353.

66. R. Frlan, S. Gobec, Curr. Med. Chem. 2006, 13, 2309-2327.

67. R. Ettari, L. Tamborini, I. C. Angelo, N. Micale, A. Pinto, C. De Micheli, P. Conti, J. Med. Chem. 2013, 56, 5637-5658.

68. T. Schirmeister, J. Med. Chem. 1999, 42, 560-572.

69. T. Schirmeister, Biopolymers 1999, 51, 87-97.

70. T. Schirmeister, M. Peric, Bioorg. Med. Chem. 2000, 8, 1281-1291. 
71. R. Vicik, V. Hoerr, M. Glaser, M. Schultheis, E. Hansell, J. H. McKerrow, U. Holzgrabe, C. R. Caffrey, A. Ponte-Sucre, H. Moll, A. Stich, T. Schirmeister, Bioorg. Med. Chem. Lett. 2006, 16, 2753-2757.

72. R. Vicik, M. Busemann, C. Gelhaus, N. Stiefl, J. Scheiber, W. Schmitz, F. Schulz, M. Mladenovic, B. Engels, M. Leippe, K. Baumann, T. Schirmeister, ChemMedChem 2006, $1,1126-1141$.

73. A. Ponte-Sucre, R. Vicik, M. Schultheis, T. Schirmeister, H. Moll, Antimicrob. Agents Chemother. 2006, 50, 2439-2447.

74. F. Schulz, C. Gelhaus, B. Degel, R. Vicik, S. Heppner, A. Breuning, M. Lieppe, J. Gut, P. J. Rosenthal, T. Schirmeister, ChemMedChem 2007, 2, 1214-1224.

75. P. Wipf, C. P. Miller, Tetrahedron Lett. 1992, 33, 6267-6270.

76. Z. Chai, J.-P. Bouillon, D. Cahard, Chem. Commun. 2012, 48, 9471-9473.

77. A. Tolomelli, G. Cardillo, L. Gentilucci, R. Juris, A. Viola, E. Juaristi, Arkivoc 2012, 2012, 196-209.

78. T. Tanaka, K. Nakajima, K. Okawa, Bull. Chem. Soc. Jpn. 1980, 53, 1352-1355.

79. K. Okawa, K. Nakajima, Biopolymers 1981, 20, 1811-1821.

80. P. Morieux, C. Salomé, K. D. Park, J. P. Stables, H. Kohn, J. Med. Chem. 2010, 53, 57165726.

81. N. D. Ide, D. P. Galonić, W. A. van der Donk, D. Y. Gin, Synlett 2005, 2011-2014.

82. D. P. Galonić, N. D. Ide, W.A. van der Donk, D. Y. Gin, J. Am. Chem. Soc. 2005, 127, 7359-7369.

83. A. P. Spork, T. J. Donohoe, Org. Biomol. Chem. 2015, 13, 8545-8549.

84. M. A. Marsini, J. T. Reeves, J.-N. Desrosiers, M. A. Herbage, J. Savoie, Z. Li, K. R. Fandrick, C. A. Sader, B. McKibben, D. A. Gao, J. Cui, N. C. Gonnella, H. Lee, X. Wei, F. Roschangar, B. Z. Lu, C. H. Senanayake, Org. Lett. 2015, 17, 5614-5617.

85. S. Fioravanti, L. Pellacani, P. A. Tardella, A. Morreale, G. Del Signore, J. Comb. Chem. 2006, $8,808-811$.

86. S. Fioravanti, D. Massari, A. Morreale, L. Pellacani, P. A. Tardella, Tetrahedron 2008, 64, 3204-3211.

87. X. E. Hu, Tetrahedron 2004, 60, 2701-2743.

88. G. Cardillo, L. Gentilucci, A. Tolomelli, C. Tomasini, J. Org. Chem. 1998, 63, 3458-3462.

89. C. Papa, C. Tomasini, Eur. J. Org. Chem. 2000, 1569-1576.

90. B. Lygo, Tetrahedron 1995, 51, 12859-12868.

91. H. W. Heine, Z. Proctor, J. Am. Chem. Soc. 1954, 76, 1554-1556. 
92. K. Hori, T. Nishiguchi, A. Nabeya, J. Org. Chem. 1997, 62, 3081-3088.

93. D. Ferraris, W. J. Drury III, C. Cox, T. Lectka, J. Org. Chem. 1998, 63, 4568-4569.

94. H. W. Heine, W. G. Kenyon, E. M. Johnson, J. Am. Chem. Soc. 1961, 83, 2570-2574.

95. H. W. Heine, M. E. Fetter, E. M. Nicholson, J. Am. Chem. Soc. 1959, 81, 2202-2204.

96. H. W. Heine, Angew. Chem. Int. Ed. 1962, 1, 528-532.

97. G. Cardillo, L. Gentilucci, A. Tolomelli, Chem. Commun. 1999, 167-168.

98. G. Cardillo, L. Gentilucci, A. Tolomelli, Tetrahedron 1999, 55, 15151-15158.

99. M. Bucciarelli, A. Forni, I. Moretti, F. Prati, G. Torre, Tetrahedron Asymmetry 1995, 6, 2073-2080.

100. G. Cardillo, L. Gentilucci, G. P. Mohr, Eur. J. Org. Chem. 2001, 3545-3551.

101. G. Cardillo, L. Gentilucci, M. Gianotti, A. Tolomelli, Tetrahedron 2001, 57, 2807-2812.

102. G. Cardillo, L. Gentilucci, M. Gianotti, A. Tolomelli, Tetrahedron Asymmetry 2001, 12, $563-569$.

103. T. L. Gilchrist, Aldrichim. Acta 2001, 34, 51-55.

104. G. R. Heintzelman, I. R. Meigh, Y. R. Mahajan, S. M. Weinreb, Org. React. 2005, 65, 141599.

105. V. Nair, J. Org. Chem. 1972, 37, 2508-2510.

106. A. Hassner, D. J. Anderson, J. Org. Chem. 1974, 39, 2031-2036.

107. M. J. Alves, A. G. Fortes, A. Lemos, C. Martinsa, Synthesis 2005, 555-558.

108. M. J. Alves, T. L. Gilchrist, J. Chem. Soc., Perkin Trans. I, 1998, 299-304.

109. A. S. Timén, P. Somfai, J. Org. Chem. 2003, 68, 9958-9963.

110. A. S. Timén, A. Fischer, P. Somfai, Chem. Commun. 2003, 1150-1151.

111. C. A. Ray, E. Risberg, P. Somfai, Tetrahedron Lett. 2001, 42, 9289-9291.

112. P. Bhullar, T. L. Gilchrist, P. Maddocks, Synthesis 1997, 271-272.

113. Y. S. P. Álvares, M. J. Alves, N. G. Azoia, J. F. Bickley, T. L. Gilchrist, J. Chem. Soc., Perkin Trans. I. 2002, 1911-1919.

114. M. J. Alves, M. M. Duraes, A. G. Fortes, Tetrahedron 2004, 60, 6541-6553.

115. G. G. Dubinina, W. Y. Yoshida, W. J. Chain, Tetrahedron Lett. 2010, 51, 5325-5327.

116. C. A. Ray, E. Risberg, P. Somfai, Tetrahedron 2002, 58, 5983-5987.

117. A. L. Logothetis, J. Org. Chem. 1964, 29, 3049-3052.

118. T. M. V. D. Pinho e Melo, A. L. Cardoso, C. S. B. Gomes, A. M. d'A. R. Gonsalves, Tetrahedron Lett. 2003, 44, 6313-6315.

119. V. Nair, Tetrahedron Lett.1971, 12, 4831-4833.

120. S. Zen, K. Harada, Chem. Lett. 1982, 1711-1714. 
121. C. Nájera, J. M. Sansano, Curr. Org. Chem. 2003, 7, 1105-1150.

122. B. Bdiri, B.-J. Zhao, Z.-M. Zhou, Tetrahedron Asymmetry 2017, 28, 876-899.

123. J. Adrio, J. C. Carretero, Chem. Commun. 2014, 50, 12434-12446.

124. A. V. Gulevskaya, J. I. Nelina-Nemtseva, Chem. Het. Comp. 2018, 54, 1084-1107.

125. J. H. Ryan, ARKIVOC 2015, (i), 160-183.

126. H. W. Heine, R. Peavy, Tetrahedron Lett. 1965, 35, 3123-3126.

127. R. Huisgen, W. Scheer, G. Szeimies, H. Huber, Tetrahedron Lett. 1966, 4, 397-404.

128. R. Grigg, P. Kennewell, V. Savic, V. Sridharan, Tetrahedron 1992, 48, 10423-10430.

129. B. B. Snider, Y. Ahn, S. M. O’Hare, Org. Lett. 2001, 3, 4217-4220.

130. A. Arany, D. Bendell, P. W. Groundwater, I. Garnett, M. Nyerges, J. Chem. Soc., Perkin Trans. I. 1999, 2605-2608.

131. J. M. Minguez, I. Castellote, J. J. Vaquero, J. L. G. Navio, J. Alvarez-Builla, O. Castano, J. L. Andres, Tetrahedron 1997, 53, 9341-9356.

132. B. Musicki, J. Org. Chem. 1990, 55, 910-918.

133. E. Vedejs, J. W. Grissom, J. Am. Chem. Soc. 1988, 110, 3238-3246.

134. S. Karlsson, F. Han, H.-E. Högberg, P. Caldirola, Tetrahedron Asymmetry 1999, 10, 26052616.

135. P. Srihari, S. R. Yaragorla, D. Basu, S. Chandrasekhar, Synthesis 2006, 2646-2648.

136. A. F. Khlebnikov, M. S. Novikov, P. P. Petrovskii, H. Stoeckli-Evans, J. Org. Chem. 2011, $76,5384-5391$.

137. D. Brown, G. A. Brown, M. Andrews, J. M. Large, D. Urban, C. P. Butts, N. J. Hales, T. Gallagher, J. Chem. Soc., Perkin Trans. I. 2002, 2014-2021.

138. D. Chandrasekhar, S. Borra, J. B. Nanubolu, R. A. Maurya, Org. Lett. 2016, 18, 29742977.

139. S. Borra, D. Chandrasekhar, S. Adhikary, S. Rasala, S. Gokulnath, R. A. Maurya, J. Org. Chem. 2017, 82, 2249-2256.

140. C.-B. Cui, H. Kakeya, H. Osada, Tetrahedron 1996, 52, 12651-12666.

141. A. Jossang, P. Jossang, H. A. Hadi, T. Sevenet, B. Bodo, J. Org. Chem. 1991, 56, 65276530.

142. J. C. Seaton, L. Marion, Can. J. Chem. 1957, 35, 1102-1108.

143. M. Ishikura, K. Yamada, Nat. Prod. Rep. 2009, 26, 803-852.

144. B. Yu, D.-Q. Yu, H.-M. Liu, Eur. J. Med. Chem. 2015, 97, 673-698.

145. Y. Zheng, C. M. Tice, S. B. Singh, Bioorg. Med. Chem. Lett. 2014, 24, 3673-3682.

146. C. V. Galliford, K. A. Scheidt, Angew. Chem. Int. Ed. 2007, 46, 8748-8758. 
147. M. Rottmann, C. McNamara, B. K. Yeung, M. C. Lee, B. Zou, B. Russell, P. Seitz, D. M. Plouffe, N. V. Dharia, J. Tan, S. B. Cohen, K. R. Spencer, G. E. Gonzalez-Paez, S. B. Lakshminarayana, A. Goh, R. Suwanarusk, T. Jegla, E. K. Schmitt, H. P. Beck, R. Brun, F. Nosten, L. Renia, V. Dartois, T. H. Keller, D. A. Fidock, E. A. Winzeler, T. T. Diagana, Science 2010, 329, 1175-1180.

148. A. M. Sosin, A. M. Burger, A. Siddiqi, J. Abrams, R. M. Mohammad, A. M. Al-Katib, J. Hematol. Oncol. 2012, 5:57.

149. Y. Zhao, S. Yu, W. Sun, L. Liu, J. Lu, D. McEachern, S. Shargary, D. Bernard, X. Li, T. Zhao, P. Zou, D. Sun, S. Wang, J. Med. Chem. 2013, 56, 5553-5561.

150. P. Gines, F. Wong, H. Watson, S. Milutinovic, L. R. del Arbol, D. Olteanu, Hepatology 2008, 48, 204-213.

151. G.-J. Mei, F. Shi, Chem. Commun. 2018, 54, 6607-6621.

152. G. S. Singh, Z. Y. Desta, Chem. Rev. 2012, 112, 6104-6155.

153. N. Arumugam, A. I. Almansour, R. S. Kumar, V. S. Periasamy, J. Athinarayanan, A. A. Alshatwi, P. Govindasami, M. Altaf, J. C. Menéndez, Tetrahedron 2018, 74, 5358-5366.

154. T. L. Pavlovskaya, R. G. Red'kin, F. G. Yaremenko, S. V. Shishkina, O. V. Shishkin, V. I. Musatov, V. V. Lipson, Chem. Het. Comp. 2013, 49, 882-896.

155. S. Vidya, K. Priya, D. V. Jayasree, A. Deepthi, P. G. Biju, Synth. Commun. 2019, 49, $1592-1602$.

156. Y.-L. Qian, B. Li, P.-J. Xia, J. Wang, H.-Y. Xiang, H. Yang, Tetrahedron 2018, 74, $6821-6828$.

157. A. I. Almansour, N. Arumugam, R. S. Kumar, G. Periyasami, H. A. Ghabbour, H.-K. Fun, Molecules 2015, 20, 780-791.

158. J. Liu, H. Sun, X. Liu, L. Ouyang, T. Kang, Y. Xie, X. Wang, Tetrahedron Lett. 2012, 53, 2336-2340.

159. S. Muthusamy, S. G. Kumar, Org. Biomol. Chem. 2016, 14, 2228-2240.

160. S. Muthusamy, S. G. Kumar, Tetrahedron 2016, 72, 2392-2401.

161. J. P. MacDonald, B. H. Shupe, J. D. Schreiber, A. K. Franz, Chem. Commun. 2014, 50, $5242-5244$.

162. H.-Z. Gui, Y.-N. Gao, Y. Wei, M. Shi, Chem. Eur. J. 2018, 24, 10038-10043.

163. Y. You, W.-Y. Lu, Z.-H. Wang, Yo.-Z. Chen, X.-Yi. Xu, X.-M. Zhang, W.-C. Yuan, Org. Lett. 2018, 20, 4453-4457.

164. L. Tian, X.-Q. Hu, Y.-H. Li, P.-F. Xu, Chem. Commun. 2013, 49, 7213-7215. 
165. H. Zhao, X. Chen, Z. Yang, T. Tian, B. Li, W. Meng, X. Song, H. Pang, RSC Adv. 2015, $5,103116-103122$.

166. J.-Q. Zhang, Z.-Ha. Qi, S.-J. Yin, H.-Y. Li, Y. Wang, X.-W. Wang, ChemCatChem 2016, $8,1-12$.

167. Y.-H. Sun, Y. Xiong, C.-Q. Peng, W. Li, J.-A. Xiao, H. Yang, Org. Biomol. Chem. 2015, $13,7907-7910$.

168. K. Suman, S. Thennarasu, RSC Adv. 2015, 5, 79413-79422.

169. Y.-L. Qian, P.-J. Xia, J. Li, Q.-L. Zhao, J.-A. Xiao, H. Xiang, H. Yang, Org. Biomol. Chem. 2017, 15, 8705-8708.

170. Y.-M. Wang, H.-H. Zhang, C. Li, T. Fana, F. Shi, Chem. Commun. 2016, 52, 1804-1807.

171. M. R. Grimmett, Imidazole and Benzimidazole Synthesis (Best Synthetic Methods), Academic Press, 1997.

172. N. Xi, Q. Huang, L. Liu, Comprehensive Heterocyclic Chemistry III: Volume 4: Fivemembered Rings with Two Heteroatoms, each with their Fused Carbocyclic Derivatives: 4.02 - Imidazoles; Elsevier Science, 2008.

173. R. Rossi, G. Angelici, G. Casotti, C. Manzini, M. Lessi, Adv. Synth. Catal. 2019, 361, 2737-2803.

174. A. Padwa, M. Dharan, J. Smolanoff, S. I. Wetmore, J. Am. Chem. Soc. 1973, 95, 19451953.

175. A. Padwa, J. Smolanoff, A. Tremper, J. Am. Chem. Soc. 1975, 97, 4682-4691.

176. A. Padwa, J. K. Rasmussen, A. Tremper, J. Am. Chem. Soc. 1976, 98, 2605-2614.

177. F. Müller, J. Mattay, Angew. Chem. Int. Ed.. 1991, 30, 1336-1337.

178. F. Müller, J. Mattay, Chem. Ber. 1993, 126, 543-549.

179. A. L. Cardoso, A. Lemos, T. M. V. D. Pinho e Melo, Eur. J. Org. Chem. 2014, 5159-5165.

180. S. Auricchio, A. M. Truscello, M. Lauria, S. V. Meille, Tetrahedron 2012, 68, 7441-7449.

181. T. A. Rossa, M. Fantinel, A. J. Bortoluzzi, M. M. Sá, Eur. J. Org. Chem. 2018, 4171-4177.

182. D. K. Tiwari, R. A. Maurya, J. B. Nanubolu, Chem. Eur. J. 2016, 22, 526-530.

183. P. R. Adiyala, S. Borra, A. Kamal, R. A. Maurya, Eur. J. Org. Chem. 2016, 1269-1273.

184. L. Xiang, Y. Niu, X. Pang, X. Yang, R. Yan, Chem. Commun. 2015, 51, 6598-6600.

185. S. Pusch, T. Opatz, Org. Lett. 2014, 16, 5430-5433.

186. J. Luo, W. Chen, J. Shao, X. Liu, K. Shu, P. Tang, Y. Yu, RSC Adv. 2015, 5, 55808-55811.

187. S. Shi, K. Xu, C. Jiang, Z. Ding, J. Org. Chem. 2018, 83, 14791-14796.

188. D. An, X. Guan, R. Guan, L. Jin, G. Zhang, S. Zhang, Chem. Commun. 2016, 52, 1121111214 
189. N. S. Y. Loy, A. Singh, X. Xu, C.-M. Park, Angew. Chem. Int. Ed. 2013, 52, 2212-2216.

190. L. Zhu, Y. Yu, Z. Mao, X. Huang, Org. Lett. 2015, 17, 30-33.

191. A. G. Hortmann, D. A. Robertson, B. K. Gillard, J. Org. Chem. 1972, 37, 322-324.

192. M. M. H. Verstappen, G. J. A. Ariaans, B. Zwanenburg, J. Am. Chem. Soc. 1996, 118, 8491-8492.

193. J. E. Beddow, S. G. Davies, K. B. Ling, P. M. Roberts, A. J. Russell, A. D. Smith, J. E. Thomson, Org. Biomol. Chem. 2007, 5, 2812-2825.

194. A. Angyal, A. Demjén, E. Wéber, A. K. Kovács, J. Wölfling, L. G. Puskás, I. Kanizsai, J. Org. Chem. 2018, 83, 3570-3581.

195. B. Olofsson, P. Somfai, J. Org. Chem. 2002, 67, 8574-8583.

196. A. Angyal, A. Demjén, V. Harmat, J. Wölfling, L. G. Puskás, I. Kanizsai, J. Org. Chem. 2019, 84, 4273-4281.

197. R. D. Taylor, M. MacCoss, A. D. G. Lawson, J. Med. Chem. 2014, 57, 5845-5859.

198. X.-C. Cheng, Q. Wang, H. Fang, W.-F. Xu, Curr. Med. Chem. 2008, 15, 374-385.

199. X. Li, J. Li, Mini Rev. Med. Chem. 2010, 10, 794-805.

200. B. A. Chalyk, M. V. Butko, O. O. Yanshyna, K. S. Gavrilenko, T. V. Druzhenko, P. K. Mykhailiuk, Chem. Eur. J. 2017, 23, 16782-16786.

201. G. Pandey, P. Banerjee, S. R. Gadre, Chem. Rev. 2006, 106, 4484-4517.

202. A. Angyal, A. Demjén, J. Wölfling, L. G. Puskás, I. Kanizsai, J. Org. Chem. 2020, 85, $3587-3595$.

203. F. W. Eastwood, P. Perlmutter, Q. Yang, J. Chem. Soc., Perkin Trans. I. 1997, 35-42.

204. D. N. Harpp, J. G. McDonald, Tetrahedron Lett. 1983, 24, 4927-4930.

205. M. Cordier, A. Archambeau, Org. Lett. 2018, 20, 2265-2268. 


\section{Köszönetnyilvánítás}

Köszönettel tartozom témavezetőimnek, Dr. Kanizsai Ivánnak (Avidin Kft.) és Dr. Wölfling János tanszékvezető egyetemi tanárnak, valamint az Avidin Kft. igazgatójának, Dr. Puskás Lászlónak, kutatásom feltételeinek biztosításáért, hasznos tanácsaikért és a doktori munkámhoz nyújtott önzetlen segítségükért.

Hálával tartozom az Avidin Kft. minden tagjának, különösképpen Demjén Andrásnak, akihez bármikor fordulhattam a munkám során felmerülő kérdéseimmel és problémáimmal. Külön köszönettel tartozom családomnak és férjemnek, akik mindvégig támogattak és biztattak.

A kutatási eredmények részben az Európai Unió támogatásával, az Európai Szociális Alap társfinanszírozásával, az EFOP-3.6.2-16-2017-00005 azonosítószámú, „Ultragyors fizikai folyamatok atomokban, molekulákban, nanoszerkezetekben és biológiai rendszerekben" címü forrás segítségével jöttek létre. 


\section{Melléklet}

Táblázat M1. Imidazolszintézis optimalizálása: savak hatása szobahőmérsékleten és $60^{\circ} \mathrm{C}-\mathrm{on}^{\mathrm{a}}$

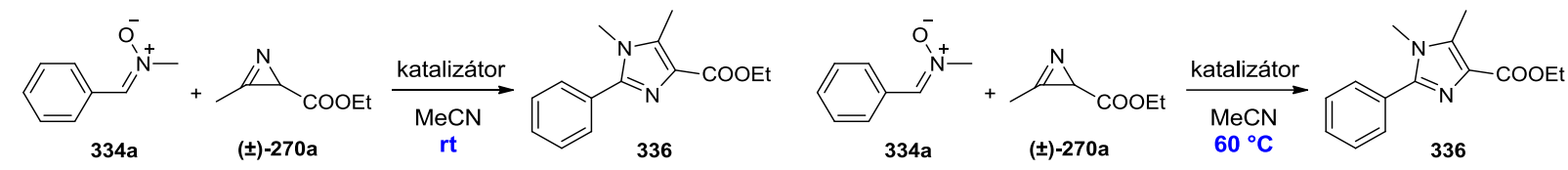

\begin{tabular}{|c|c|c|c|c|c|}
\hline Kísérlet & Katalizátor & $\begin{array}{c}\mathbf{t} \\
\text { (óra) }\end{array}$ & \multicolumn{2}{|c|}{$\begin{array}{c}\text { Konverzió. } \\
(\%)\end{array}$} & $\begin{array}{c}\text { Hozam } \\
(\%)^{b}\end{array}$ \\
\hline 1 & \multirow[b]{2}{*}{-} & 8 & 0 & 0 & 0 \\
\hline 2 & & 24 & 1 & 2 & 0 \\
\hline 3 & \multirow{2}{*}{$\mathrm{HCOOH}$} & 8 & 18 & 24 & 10 \\
\hline 4 & & 24 & 45 & 62 & 36 \\
\hline 5 & \multirow{2}{*}{$\mathrm{AcOH}$} & 8 & 0 & 0 & 0 \\
\hline 6 & & 24 & 0 & 0 & 0 \\
\hline 7 & \multirow{2}{*}{ TFA } & 8 & 74 & 98 & 59 \\
\hline 8 & & 24 & 77 & 100 & 62 \\
\hline 9 & \multirow{2}{*}{$\mathrm{MeSO}_{3} \mathrm{H}$} & 8 & 58 & 86 & 50 \\
\hline 10 & & 24 & 59 & 100 & 52 \\
\hline 11 & \multirow{2}{*}{$\mathrm{PTSA} \times \mathrm{H}_{2} \mathrm{O}$} & 8 & 60 & 100 & 56 \\
\hline 12 & & 24 & 63 & 100 & 57 \\
\hline 13 & \multirow{2}{*}{$\mathrm{HClO}_{4}(70 \%)$} & 8 & 63 & 100 & 56 \\
\hline 14 & & 24 & 63 & 100 & 56 \\
\hline 15 & \multirow{2}{*}{$\mathrm{H}_{2} \mathrm{SO}_{4}$} & 8 & 53 & 60 & 36 \\
\hline 16 & & 24 & 67 & 78 & 49 \\
\hline 17 & \multirow{2}{*}{$\mathrm{NaHSO}_{4}$} & 8 & 18 & 20 & 14 \\
\hline 18 & & 24 & 35 & 38 & 28 \\
\hline 19 & \multirow{2}{*}{$\mathrm{B}(\mathrm{OH})_{3}$} & 8 & 0 & 0 & 0 \\
\hline 20 & & 24 & 50 & 77 & 35 \\
\hline 21 & \multirow{2}{*}{$\mathrm{PTA}^{\dagger}$} & 8 & 66 & 100 & 52 \\
\hline 22 & & 24 & 68 & 100 & 54 \\
\hline 23 & \multirow{2}{*}{$\begin{array}{c}\text { BINOL- } \\
\text { foszforsav }^{\dagger \dagger}\end{array}$} & 8 & 48 & 70 & 41 \\
\hline 24 & & 24 & 58 & 87 & 52 \\
\hline 25 & \multirow{2}{*}{ Szilikagél ${ }^{\mathrm{d}, \mathrm{e}}$} & 8 & 5 & 6 & 1 \\
\hline 26 & & 24 & 18 & 40 & 16 \\
\hline 27 & \multirow{2}{*}{ Amberlyst $15^{\mathrm{d}}$} & 8 & 77 & 52 & 0 \\
\hline 28 & & 24 & 82 & 83 & 1 \\
\hline 29 & \multirow{2}{*}{$\begin{array}{c}\text { Montmorillonite } \\
\mathrm{K} 10^{\mathrm{d}}\end{array}$} & 8 & 20 & 38 & 9 \\
\hline 30 & & 24 & 46 & 82 & 22 \\
\hline 31 & \multirow{2}{*}{$\mathrm{ZnCl}_{2}$} & 8 & 14 & 100 & 7 \\
\hline 32 & & 24 & 26 & 100 & 8 \\
\hline 33 & \multirow{2}{*}{$\mathrm{Zn}(\mathrm{OAc})_{2}$} & 8 & 22 & 100 & 6 \\
\hline 34 & & 24 & 28 & 100 & 7 \\
\hline 35 & \multirow{2}{*}{$\mathrm{ZnF}_{2}$} & 8 & 0 & 0 & 0 \\
\hline 36 & & 24 & 0 & 0 & 0 \\
\hline 37 & \multirow{2}{*}{$\mathrm{InCl}_{3}$} & 8 & 15 & 100 & 11 \\
\hline 38 & & 24 & 18 & 100 & 12 \\
\hline 39 & \multirow{2}{*}{$\operatorname{In}(\mathrm{OAc})_{3}$} & 8 & 0 & 0 & 0 \\
\hline 40 & & 24 & 4 & 11 & 2 \\
\hline 41 & $\operatorname{In}(\mathrm{OTf})_{2}$ & 8 & 46 & 100 & 37 \\
\hline 42 & $11(011)_{3}$ & 24 & 48 & 100 & 39 \\
\hline
\end{tabular}

\begin{tabular}{|c|c|c|c|c|c|}
\hline \multirow{4}{*}{\begin{tabular}{c|} 
Kísérlet \\
63 \\
64
\end{tabular}} & \multirow[t]{2}{*}{ Katalizátor } & \multirow{2}{*}{$\begin{array}{c}\mathbf{t} \\
\text { (óra) }\end{array}$} & \multicolumn{2}{|c|}{$\begin{array}{c}\text { Konverzió. } \\
(\%)\end{array}$} & \multirow{2}{*}{$\begin{array}{l}\text { Hozam } \\
(\%)^{c}\end{array}$} \\
\hline & & & 334a & 270a & \\
\hline & \multirow{2}{*}{-} & 8 & 2 & 4 & 0 \\
\hline & & 24 & 5 & 7 & 0 \\
\hline 65 & \multirow{2}{*}{$\mathrm{HCOOH}$} & 8 & 67 & 100 & 42 \\
\hline 66 & & 24 & 68 & 100 & 42 \\
\hline 67 & \multirow{2}{*}{$\mathrm{AcOH}$} & 8 & 9 & 28 & 4 \\
\hline 68 & & 24 & 44 & 87 & 17 \\
\hline 69 & \multirow{2}{*}{ TFA } & 8 & 62 & 97 & 50 \\
\hline 70 & & 24 & 64 & 100 & 50 \\
\hline 71 & \multirow{2}{*}{$\mathrm{MeSO}_{3} \mathrm{H}$} & 8 & 54 & 96 & 40 \\
\hline 72 & & 24 & 58 & 100 & 42 \\
\hline 73 & \multirow{2}{*}{$\mathrm{PTSA} \times \mathrm{H}_{2} \mathrm{O}$} & 8 & 53 & 100 & 43 \\
\hline 74 & & 24 & 54 & 100 & 44 \\
\hline 75 & \multirow{2}{*}{$\mathrm{HClO}_{4}(70 \%)$} & 8 & 58 & 98 & 49 \\
\hline 76 & & 24 & 59 & 100 & 48 \\
\hline 77 & \multirow{2}{*}{$\mathrm{H}_{2} \mathrm{SO}_{4}$} & 8 & 72 & 100 & 42 \\
\hline 78 & & 24 & 74 & 100 & 41 \\
\hline 79 & \multirow{2}{*}{$\mathrm{NaHSO}_{4}$} & 8 & 48 & 61 & 23 \\
\hline 80 & & 24 & 61 & 82 & 30 \\
\hline 81 & \multirow{2}{*}{$\mathrm{B}(\mathrm{OH})_{3}$} & 8 & 53 & 97 & 38 \\
\hline 82 & & 24 & 54 & 100 & 39 \\
\hline 83 & \multirow{2}{*}{$\mathrm{PTA}^{\dagger}$} & 8 & 70 & 98 & 47 \\
\hline 84 & & 24 & 72 & 100 & 49 \\
\hline 85 & \multirow{2}{*}{$\begin{array}{l}\text { BINOL- } \\
\text { foszforsav }{ }^{\dagger \dagger}\end{array}$} & 8 & 52 & 100 & 42 \\
\hline 86 & & 24 & 52 & 100 & 43 \\
\hline 87 & \multirow{2}{*}{ Szilikagél ${ }^{\mathrm{d}, \mathrm{e}}$} & 8 & 51 & 76 & 34 \\
\hline 88 & & 24 & 65 & 100 & 41 \\
\hline 89 & \multirow{2}{*}{ Amberlyst $15^{\mathrm{d}}$} & 8 & 91 & 86 & 1 \\
\hline 90 & & 24 & 94 & 100 & 1 \\
\hline 91 & Montmorillonite & 8 & 59 & 98 & 21 \\
\hline 92 & $\mathrm{~K} 10^{\mathrm{d}}$ & 24 & 64 & 100 & 22 \\
\hline 93 & \multirow{2}{*}{$\mathrm{ZnCl}_{2}$} & 8 & 30 & 100 & 21 \\
\hline 94 & & 24 & 33 & 100 & 22 \\
\hline 95 & \multirow{2}{*}{$\mathrm{Zn}(\mathrm{OAc})_{2}$} & 8 & 27 & 100 & 10 \\
\hline 96 & & 24 & 29 & 100 & 9 \\
\hline 97 & \multirow{2}{*}{$\mathrm{ZnF}_{2}$} & 8 & 2 & 31 & 1 \\
\hline 98 & & 24 & 46 & 100 & 22 \\
\hline 99 & \multirow{2}{*}{$\mathrm{InCl}_{3}$} & 8 & 28 & 100 & 20 \\
\hline 100 & & 24 & 41 & 100 & 21 \\
\hline 101 & \multirow{2}{*}{$\operatorname{In}(\mathrm{OAc})_{3}$} & 8 & 26 & 100 & 19 \\
\hline 102 & & 24 & 28 & 100 & 20 \\
\hline 103 & $\operatorname{In}(\mathrm{O} T \mathrm{f})$ & 8 & 49 & 100 & 33 \\
\hline 104 & $\mathrm{~m}(\mathrm{OII})_{3}$ & 24 & 51 & 100 & 35 \\
\hline
\end{tabular}




\begin{tabular}{|c|c|c|c|c|c|c|c|c|c|c|c|}
\hline $\begin{array}{l}43 \\
44\end{array}$ & $\mathrm{FeCl}_{2} \times 4 \mathrm{H}_{2} \mathrm{O}$ & $\begin{array}{c}8 \\
24\end{array}$ & $\begin{array}{l}28 \\
48\end{array}$ & $\begin{array}{c}75 \\
100\end{array}$ & $\begin{array}{l}3 \\
4\end{array}$ & $\begin{array}{l}105 \\
106\end{array}$ & $\mathrm{FeCl}_{2} \times 4 \mathrm{H}_{2} \mathrm{O}$ & $\begin{array}{c}8 \\
24\end{array}$ & $\begin{array}{l}87 \\
93\end{array}$ & $\begin{array}{l}100 \\
100\end{array}$ & $\begin{array}{l}30 \\
31\end{array}$ \\
\hline $\begin{array}{l}45 \\
46\end{array}$ & $\mathrm{FeCl}_{3} \times 6 \mathrm{H}_{2} \mathrm{O}$ & $\begin{array}{c}8 \\
24\end{array}$ & $\begin{array}{l}39 \\
59\end{array}$ & $\begin{array}{c}81 \\
100\end{array}$ & $\begin{array}{l}6 \\
7\end{array}$ & $\begin{array}{l}107 \\
108\end{array}$ & $\mathrm{FeCl}_{3} \times 6 \mathrm{H}_{2} \mathrm{O}$ & $\begin{array}{c}8 \\
24\end{array}$ & $\begin{array}{c}87 \\
100\end{array}$ & $\begin{array}{l}100 \\
100\end{array}$ & $\begin{array}{l}21 \\
20\end{array}$ \\
\hline $\begin{array}{l}47 \\
48\end{array}$ & $\mathrm{CuCl}$ & $\begin{array}{c}8 \\
24\end{array}$ & $\begin{array}{l}50 \\
65\end{array}$ & $\begin{array}{c}70 \\
100\end{array}$ & $\begin{array}{l}2 \\
2\end{array}$ & $\begin{array}{l}109 \\
110\end{array}$ & $\mathrm{CuCl}$ & $\begin{array}{c}8 \\
24\end{array}$ & $\begin{array}{l}42 \\
60\end{array}$ & $\begin{array}{c}99 \\
100\end{array}$ & $\begin{array}{l}12 \\
13\end{array}$ \\
\hline $\begin{array}{l}49 \\
50\end{array}$ & $\mathrm{CuCl}_{2}$ & $\begin{array}{c}8 \\
24\end{array}$ & $\begin{array}{l}56 \\
82\end{array}$ & $\begin{array}{l}100 \\
100\end{array}$ & $\begin{array}{l}3 \\
3\end{array}$ & $\begin{array}{l}111 \\
112\end{array}$ & $\mathrm{CuCl}_{2}$ & $\begin{array}{c}8 \\
24\end{array}$ & $\begin{array}{l}42 \\
66\end{array}$ & $\begin{array}{l}100 \\
100\end{array}$ & $\begin{array}{l}16 \\
16\end{array}$ \\
\hline $\begin{array}{l}51 \\
52\end{array}$ & $\mathrm{Cu}(\mathrm{OAc})_{2}$ & $\begin{array}{c}8 \\
24\end{array}$ & $\begin{array}{l}14 \\
42\end{array}$ & $\begin{array}{c}49 \\
100\end{array}$ & $\begin{array}{l}0 \\
2\end{array}$ & $\begin{array}{l}113 \\
114\end{array}$ & $\mathrm{Cu}(\mathrm{OAc})_{2}$ & $\begin{array}{c}8 \\
24\end{array}$ & $\begin{array}{l}23 \\
39\end{array}$ & $\begin{array}{l}100 \\
100\end{array}$ & $\begin{array}{l}2 \\
2\end{array}$ \\
\hline $\begin{array}{l}53 \\
54\end{array}$ & $\mathrm{Cu}(\mathrm{OTf})_{2}$ & $\begin{array}{c}8 \\
24\end{array}$ & $\begin{array}{l}40 \\
54\end{array}$ & $\begin{array}{l}100 \\
100\end{array}$ & $\begin{array}{l}11 \\
12\end{array}$ & $\begin{array}{l}115 \\
116\end{array}$ & $\mathrm{Cu}(\mathrm{OTf})_{2}$ & $\begin{array}{c}8 \\
24\end{array}$ & $\begin{array}{l}45 \\
59\end{array}$ & $\begin{array}{l}100 \\
100\end{array}$ & $\begin{array}{l}24 \\
23\end{array}$ \\
\hline $\begin{array}{l}55 \\
56\end{array}$ & $\operatorname{Mg}(\mathrm{OTf})_{2}$ & $\begin{array}{c}8 \\
24\end{array}$ & $\begin{array}{l}58 \\
63\end{array}$ & $\begin{array}{l}100 \\
100\end{array}$ & $\begin{array}{l}52 \\
56\end{array}$ & $\begin{array}{l}117 \\
118\end{array}$ & $\operatorname{Mg}(\mathrm{OTf})_{2}$ & $\begin{array}{c}8 \\
24\end{array}$ & $\begin{array}{l}35 \\
39\end{array}$ & $\begin{array}{l}100 \\
100\end{array}$ & $\begin{array}{l}34 \\
37\end{array}$ \\
\hline $\begin{array}{l}57 \\
58\end{array}$ & $\mathrm{Yb}(\mathrm{OTf})_{3}$ & $\begin{array}{c}8 \\
24\end{array}$ & $\begin{array}{l}58 \\
60\end{array}$ & $\begin{array}{l}100 \\
100\end{array}$ & $\begin{array}{l}56 \\
57\end{array}$ & $\begin{array}{l}119 \\
120\end{array}$ & $\mathrm{Yb}(\mathrm{OTf})_{3}$ & $\begin{array}{c}8 \\
24\end{array}$ & $\begin{array}{l}54 \\
55\end{array}$ & $\begin{array}{l}100 \\
100\end{array}$ & $\begin{array}{l}39 \\
39\end{array}$ \\
\hline $\begin{array}{l}59 \\
60\end{array}$ & $\mathrm{Sc}(\mathrm{OTf})_{3}$ & $\begin{array}{c}8 \\
24\end{array}$ & $\begin{array}{l}61 \\
65\end{array}$ & $\begin{array}{c}94 \\
100\end{array}$ & $\begin{array}{l}53 \\
56\end{array}$ & $\begin{array}{l}121 \\
122\end{array}$ & $\mathrm{Sc}(\mathrm{OTf})_{3}$ & $\begin{array}{c}8 \\
24\end{array}$ & $\begin{array}{l}60 \\
61\end{array}$ & $\begin{array}{l}100 \\
100\end{array}$ & $\begin{array}{l}41 \\
42\end{array}$ \\
\hline $\begin{array}{l}61 \\
62\end{array}$ & $\operatorname{Dy}(\mathrm{OTf})_{3}$ & $\begin{array}{c}8 \\
24\end{array}$ & $\begin{array}{l}63 \\
66\end{array}$ & $\begin{array}{c}94 \\
100\end{array}$ & $\begin{array}{l}57 \\
59\end{array}$ & $\begin{array}{l}123 \\
124\end{array}$ & $\operatorname{Dy}(\mathrm{OTf})_{3}$ & $\begin{array}{c}8 \\
24\end{array}$ & $\begin{array}{l}53 \\
51\end{array}$ & $\begin{array}{c}97 \\
100\end{array}$ & $\begin{array}{l}36 \\
39\end{array}$ \\
\hline
\end{tabular}

${ }^{[a]}$ Reakciókörülmények: nitron $(0,10 \mathrm{mmol}), 2 \mathrm{H}$-azirin $(0,10 \mathrm{mmol})$, vízmentes $\mathrm{MeCN}(0,3 \mathrm{ml})$, katalizátor $(10 \mathrm{~mol} \%), 24$ óra. ${ }^{\left[{ }^{b}\right]}$ Szobahőmérséklet. HPLC-MS méréssel meghatározott hozamok (336 kalibrációjával). ${ }^{\left[{ }^{[c]}\right.} 60{ }^{\circ} \mathrm{C}$. HPLC-MS méréssel meghatározott hozamok (336 kalibrációjával). ${ }^{[\mathrm{d]}} 10 \mathrm{w} / \mathrm{v} \%$-ot alkalmaztunk. ${ }^{\left[{ }^{[\mathrm{e}} 60\right.} \AA$ \&, 70-230 mesh. ${ }^{\dagger}$ Foszfor-volfrámsav. ${ }^{\dagger 1} 1,1^{\prime}$-Binaftil-2,2'-diil-hidrogén-foszfát. 
Táblázat M2. Imidazolszintézis optimalizálása: oldószerek hatása ${ }^{a}$<smiles>CCOC(=O)c1nc(-c2ccccc2)n(C)c1C</smiles>

\begin{tabular}{|c|c|c|c|c|c|}
\hline Kísérlet & Oldószer & $\begin{array}{c}\text { t } \\
\text { (óra) }\end{array}$ & \multicolumn{2}{|c|}{$\begin{array}{c}\text { Konverzió } \\
(\%)\end{array}$} & $\begin{array}{c}\text { Hozam } \\
(\%)^{\mathrm{b}}\end{array}$ \\
\hline 1 & \multirow{3}{*}{$\mathrm{MeOH}$} & 3 & 32 & 53 & 20 \\
\hline 2 & & 8 & 47 & 81 & 34 \\
\hline 3 & & 24 & 55 & 89 & 39 \\
\hline 4 & \multirow{3}{*}{$\mathrm{EtOH}$} & 3 & 29 & 44 & 21 \\
\hline 5 & & 8 & 47 & 71 & 37 \\
\hline 6 & & 24 & 57 & 88 & 46 \\
\hline 7 & \multirow{3}{*}{ IPA } & 3 & 14 & 26 & 10 \\
\hline 8 & & 8 & 31 & 54 & 23 \\
\hline 9 & & 24 & 54 & 87 & 33 \\
\hline 10 & \multirow{3}{*}{$\mathrm{TFE}^{\mathrm{c}}$} & 3 & 7 & 18 & 2 \\
\hline 11 & & 8 & 9 & 25 & 5 \\
\hline 12 & & 24 & 23 & 50 & 14 \\
\hline 13 & \multirow{3}{*}{ HFIP $^{c}$} & 3 & 4 & 15 & 1 \\
\hline 14 & & 8 & 5 & 16 & 1 \\
\hline 15 & & 24 & 9 & 20 & 3 \\
\hline 16 & \multirow{3}{*}{$\mathrm{CHCl}_{3}$} & 3 & 25 & 40 & 18 \\
\hline 17 & & 8 & 47 & 69 & 27 \\
\hline 18 & & 24 & 56 & 93 & 39 \\
\hline 19 & \multirow{3}{*}{$\mathrm{CH}_{2} \mathrm{Cl}_{2}$} & 3 & 38 & 60 & 46 \\
\hline 20 & & 8 & 58 & 90 & 52 \\
\hline 21 & & 24 & 65 & 94 & 55 \\
\hline 22 & \multirow{3}{*}{ Toluol } & 3 & 42 & 70 & 35 \\
\hline 23 & & 8 & 54 & 100 & 41 \\
\hline 24 & & 24 & 56 & 100 & 42 \\
\hline 25 & \multirow{3}{*}{ THF } & 3 & 47 & 71 & 39 \\
\hline 26 & & 8 & 56 & 100 & 48 \\
\hline 27 & & 24 & 65 & 100 & 54 \\
\hline 28 & \multirow{3}{*}{ Dioxán } & 3 & 49 & 54 & 16 \\
\hline 29 & & 8 & 51 & 72 & 41 \\
\hline 30 & & 24 & 64 & 89 & 47 \\
\hline 31 & \multirow{3}{*}{ DMF } & 3 & 12 & 7 & 6 \\
\hline 32 & & 8 & 30 & 31 & 22 \\
\hline 33 & & 24 & 64 & 76 & 48 \\
\hline 34 & \multirow{3}{*}{ DMSO } & 3 & 2 & 3 & 1 \\
\hline 35 & & 8 & 7 & 10 & 3 \\
\hline 36 & & 24 & 24 & 33 & 13 \\
\hline 37 & \multirow{3}{*}{$\mathrm{MeCN}$} & 3 & 69 & 79 & 55 \\
\hline 38 & & 8 & 74 & 98 & 59 \\
\hline 39 & & 24 & 77 & 100 & 62 \\
\hline
\end{tabular}

${ }^{[a]}$ Reakciókörülmények: nitron $(0,10 \mathrm{mmol}), 2 \mathrm{H}$-azirin $(0,10 \mathrm{mmol})$, vízmentes oldószer $(0,3 \mathrm{ml})$, TFA $(10 \mathrm{~mol} \%) \cdot{ }^{[\mathrm{b}]}$ HPLC-MS méréssel meghatározott hozamok (336 kalibrációjával). ${ }^{[\mathrm{cc}} \mathrm{Nem}$ vízmentes. 
Táblázat M3. Imidazolszintézis optimalizálása: az azirin és a katalizátormennyiség, valamint a hőmérséklet beállítása ${ }^{\mathrm{a}}$<smiles>CCOC(=O)c1nc(-c2ccccc2)n(C)c1C</smiles>

\begin{tabular}{|c|c|c|c|c|c|c|c|}
\hline Kísérlet & $\begin{array}{c}\begin{array}{c}270 a \\
\text { (ekv.) }\end{array} \\
\text { (2) }\end{array}$ & $\begin{array}{c}\text { Katalizátor } \\
\text { mennyiség } \\
(\mathrm{mol} \%)\end{array}$ & Hőmérséklet & $\begin{array}{c}\mathbf{t} \\
\text { (óra) }\end{array}$ & $\begin{array}{c}\text { Konverzió } \\
(\mathbf{\%}) \\
\mathbf{3 3 4 a} \\
\end{array}$ & $\begin{array}{c}\text { Elreagált } \\
270 a \\
(\text { ekv.) }\end{array}$ & $\begin{array}{c}\text { Hozam } \\
(\%)^{\mathbf{b}}\end{array}$ \\
\hline 1 & & & & 3 & 69 & \begin{tabular}{|l|l|}
0,79 \\
\end{tabular} & 55 \\
\hline 2 & 1,0 & 10 & $\mathrm{rt}$ & 8 & 74 & 0,98 & 59 \\
\hline 3 & & & & 24 & 77 & 1,0 & 62 \\
\hline 4 & & & & 3 & 71 & 0,95 & 57 \\
\hline 5 & 1,25 & 10 & $\mathrm{rt}$ & 8 & 82 & 1,10 & 66 \\
\hline 6 & & & & 24 & 90 & 1,25 & 70 \\
\hline 7 & & & & 3 & 74 & 0,94 & 58 \\
\hline 8 & 1,5 & 10 & rt & 8 & 85 & 1,11 & 68 \\
\hline 9 & & & & 24 & 96 & 1,24 & 74 \\
\hline 10 & & & & 3 & 78 & 0,98 & 59 \\
\hline 11 & 2,0 & 10 & $\mathrm{rt}$ & 8 & 89 & 1,13 & 68 \\
\hline 12 & & & & 24 & 98 & 1,21 & 74 \\
\hline 13 & & & & 3 & 22 & 0,42 & 22 \\
\hline 14 & 1,5 & 1 & $\mathrm{rt}$ & 8 & 30 & 0,53 & 29 \\
\hline 15 & & & & 24 & 51 & 0,82 & 43 \\
\hline 16 & & & & 3 & 50 & 0,64 & 41 \\
\hline 17 & 1,5 & 2,5 & $\mathrm{rt}$ & 8 & 57 & 0,82 & 49 \\
\hline 18 & & & & 24 & 74 & 0,97 & 60 \\
\hline 19 & & & & 3 & 54 & 0,88 & 52 \\
\hline 20 & 1,5 & 5 & $\mathrm{rt}$ & 8 & 66 & 0,99 & 64 \\
\hline 21 & & & & 24 & 84 & 1,18 & 73 \\
\hline 22 & & & & 3 & 78 & 0,90 & 59 \\
\hline 23 & 1,5 & 15 & $\mathrm{rt}$ & 8 & 90 & 1,08 & 67 \\
\hline 24 & & & & 24 & 94 & 1,15 & 72 \\
\hline 25 & & & & 3 & 82 & 0,62 & 54 \\
\hline 26 & 1,5 & 20 & $\mathrm{rt}$ & 8 & 90 & 0,97 & 63 \\
\hline 27 & & & & 24 & 100 & 1,16 & 68 \\
\hline 28 & & & & 3 & 75 & 0,71 & 26 \\
\hline 29 & 1,5 & 40 & rt & 8 & 89 & 0,89 & 34 \\
\hline 30 & & & & 24 & 99 & 1,11 & 41 \\
\hline 31 & & & & 3 & 83 & 0,97 & 67 \\
\hline 32 & 1,5 & 10 & $40^{\circ} \mathrm{C}$ & 6 & 93 & 1,14 & 73 \\
\hline 33 & & & & 12 & 99 & 1,20 & 76 \\
\hline 34 & & & & 2 & 90 & 0,98 & 66 \\
\hline 35 & 1,5 & 5 & $60{ }^{\circ} \mathrm{C}$ & 4 & 94 & 1,10 & 69 \\
\hline 36 & & & & 6 & 96 & 1,25 & 69 \\
\hline 37 & & & & 2 & 95 & 1,09 & 76 \\
\hline 38 & 1,5 & 10 & $60^{\circ} \mathrm{C}$ & 4 & 97 & 1,13 & 77 \\
\hline 39 & & & & 6 & 99 & 1,15 & 78 \\
\hline 40 & & & & 2 & 97 & 1,13 & 58 \\
\hline 41 & 1,5 & 10 & $80^{\circ} \mathrm{C}$ & 4 & 99 & 1,25 & 59 \\
\hline 42 & & & & 6 & 100 & 1,32 & 59 \\
\hline
\end{tabular}

${ }^{[a]}$ Reakciókörülmények: nitron ( $\left.0,10 \mathrm{mmol}\right), 2 \mathrm{H}$-azirin $(0,10-0,20 \mathrm{mmol})$, vízmentes $\mathrm{MeCN}(0,3$ $\mathrm{ml})$, TFA (1-40 mol\%). ${ }^{[b]}$ HPLC-MS méréssel meghatározott hozamok (336 kalibrációjával). 
Etil-3-metil-2H-azirin-2-karboxilát (( \pm )-270a)

${ }^{1} \mathrm{H}$ NMR $\left(500 \mathrm{MHz}, \mathrm{CDCl}_{3}\right) \delta 4,26-4,10(\mathrm{~m}, 2 \mathrm{H}), 2,52$ (s, 3H), 2,43 (s, 1H), 1,26 (t, $J=7,2$ $\mathrm{Hz}, 3 \mathrm{H}) ;{ }^{13} \mathrm{C} \mathrm{NMR}\left(126 \mathrm{MHz}, \mathrm{CDCl}_{3}\right) \delta 171,6,158,7,60,7,28,4,13,8,12,2$.

terc-Butil-3-metil-2H-azirin-2-karboxilát $(( \pm)-270 b)$

${ }^{1} \mathrm{H}$ NMR $\left(500 \mathrm{MHz}, \mathrm{CDCl}_{3}\right) \delta 2,52(\mathrm{~s}, 3 \mathrm{H}), 2,34(\mathrm{~s}, 1 \mathrm{H}), 1.46(\mathrm{~s}, 9 \mathrm{H}) ;{ }^{13} \mathrm{C}$ NMR $(126 \mathrm{MHz}$, $\left.\mathrm{CDCl}_{3}\right) \delta 171,4,163,2,81,4,30,0,28,1,24,8$.

Etil-2,3-dimetil-2H-azirin-2- karboxilát $(( \pm)-270 c)$

${ }^{1} \mathrm{H}$ NMR $\left(500 \mathrm{MHz}, \mathrm{DMSO}-d_{6}\right) \delta 4,05$ (qq, $\left.J=6,9,3,8 \mathrm{~Hz}, 2 \mathrm{H}\right), 2,47$ (s, 3H), 1,33 (s, 3H), 1,16 $(\mathrm{t}, J=7,1 \mathrm{~Hz}, 3 \mathrm{H}) ;{ }^{13} \mathrm{C}$ NMR $(126 \mathrm{MHz}, \mathrm{DMSO}) \delta 173,3,164,3,61,1,33,5,17,8,14,6,11,8$; HRMS (ESI) 142,0863 [M+H] $]^{+}$(kalkulált: 142,0868).

Etil-2-benzil-3-metil-2H-azirin-2-karboxilát (( \pm$)$-270d)

${ }^{1} \mathrm{H}$ NMR $\left(500 \mathrm{MHz}\right.$, DMSO- $\left.d_{6}\right) \delta 7,25(\mathrm{t}, J=7,4 \mathrm{~Hz}, 2 \mathrm{H}), 7,17(\mathrm{t}, J=7,4 \mathrm{~Hz}, 1 \mathrm{H}), 7,13(\mathrm{~d}, J$ $=6,8 \mathrm{~Hz}, 2 \mathrm{H}), 4,02(\mathrm{qq}, J=7,0,3,7 \mathrm{~Hz}, 2 \mathrm{H}), 3,25(\mathrm{~d}, J=14,9 \mathrm{~Hz}, 1 \mathrm{H}), 3,01(\mathrm{~d}, J=14,9 \mathrm{~Hz}$, $1 \mathrm{H}), 2,30(\mathrm{~s}, 3 \mathrm{H}), 1,11(\mathrm{t}, J=7,1 \mathrm{~Hz}, 3 \mathrm{H}) ;{ }^{13} \mathrm{C}$ NMR (126 MHz, DMSO- $\left.d_{6}\right) \delta 172,7,163,5$, $137,9,129,9,128,7,126,7,61,3,38,1,36,8,14,5,12,3$; HRMS (ESI) 218,1176 [M+H] ${ }^{+}$ (kalkulált: 218,1181).

\section{2,3-Difenil-2H-azirin $(( \pm)-270 \mathrm{e})$}

${ }^{1} \mathrm{H}$ NMR $\left(500 \mathrm{MHz}, \mathrm{CDCl}_{3}\right) \delta$ 7,92 - 7,90 (m, 2H), 7.62 - 7,52 (m, 3H), 7,30 - 7,21 (m, 3H), $7,16-7,14(\mathrm{~m}, 2 \mathrm{H}), 3,32(\mathrm{~s}, 1 \mathrm{H}) ;{ }^{13} \mathrm{C} \mathrm{NMR}\left(126 \mathrm{MHz}, \mathrm{CDCl}_{3}\right) \delta 163,5,140,8,133,1,129,9$, $129,2,128,3,127,0,126,1,124,1,34,5$.

\section{3-Benzil-2-fenil-2H-azirin (( \pm -270f)}

${ }^{1} \mathrm{H}$ NMR $\left(500 \mathrm{MHz}, \mathrm{CDCl}_{3}\right) \delta$ 7,37 -7,22 (m, 8H), 7,05 - 7,03 (m, 2H), 4,17 (dd, J= 35,2 Hz, $17,2 \mathrm{~Hz}, 2 \mathrm{H}), 2,98(\mathrm{~s}, 1 \mathrm{H}) ;{ }^{13} \mathrm{C} \mathrm{NMR}\left(126 \mathrm{MHz}, \mathrm{CDCl}_{3}\right) \delta 166,6,140,9,132,7,129,0,128,9$, $128,2,127,5,126,9,125,7,34,1,33,4$.

\section{3-(4-Metoxifenil)-2-fenil-2H-azirin $(( \pm)-270 g)$}

${ }^{1} \mathrm{H}$ NMR $\left(500 \mathrm{MHz}, \mathrm{DMSO}-d_{6}\right) \delta 7,85(\mathrm{~d}, J=8,7 \mathrm{~Hz}, 2 \mathrm{H}), 7,29(\mathrm{t}, J=7,4 \mathrm{~Hz}, 2 \mathrm{H}), 7,23(\mathrm{t}, J$ $=7,3 \mathrm{~Hz}, 1 \mathrm{H}), 7,20(\mathrm{~d}, J=8,7 \mathrm{~Hz}, 2 \mathrm{H}), 7,10(\mathrm{~d}, J=7,2 \mathrm{~Hz}, 2 \mathrm{H}), 3,87(\mathrm{~s}, 3 \mathrm{H}), 3,31(\mathrm{~s}, 1 \mathrm{H}) ;{ }^{13} \mathrm{C}$ NMR $\left(126\right.$ MHz, DMSO-d $d_{6} \delta 163,8,161,6,141,8,132,2,128,8,127,3,126,3,115,9,115,7$, $60,24,56,2,40,3,33,3$.

\section{3-(4-Fluorfenil)-2-fenil-2H-azirin (( \pm )-270h)}

${ }^{1} \mathrm{H}$ NMR $\left(500 \mathrm{MHz}, \mathrm{CDCl}_{3}\right) \delta$ 7,84 - 7,92 (m, 2H), 7,31 - 7,43 (m, 2H), 7,33 (d, J=8,4 Hz, $2 \mathrm{H}), 7,23(\mathrm{~d}, J=8,4 \mathrm{~Hz}, 2 \mathrm{H}), 3,25(\mathrm{~s}, 1 \mathrm{H}) ;{ }^{13} \mathrm{C} \mathrm{NMR}\left(126 \mathrm{MHz}, \mathrm{CDCl}_{3}\right) \delta 165,2(\mathrm{~d}, J=244,1$ $\mathrm{Hz}), 162,6,137,0,129,5,128,6,128,2,125,7,125,4,115,6$ (d, $J=21,4 \mathrm{~Hz}), 28,6$.

\section{3-(4-Klórfenil)-2-fenil-2H-azirin (( \pm )-270i)}

${ }^{1} \mathrm{H}$ NMR (500 MHz, DMSO- $\left.d_{6}\right) \delta$ 7,94 (d, $\left.J=8,4 \mathrm{~Hz}, 2 \mathrm{H}\right), 7,74(\mathrm{~d}, J=8,5 \mathrm{~Hz}, 2 \mathrm{H}), 7,31(\mathrm{t}, J$ $=7,3 \mathrm{~Hz}, 2 \mathrm{H}), 7,26(\mathrm{t}, J=7,2 \mathrm{~Hz}, 1 \mathrm{H}), 7,11(\mathrm{~d}, J=7,1 \mathrm{~Hz}, 2 \mathrm{H}), 3,42(\mathrm{~s}, 1 \mathrm{H}) ;{ }^{13} \mathrm{C}$ NMR $(126$ MHz, DMSO- $\left.d_{6}\right) \delta 162,6,141,1,138,9,131,8,130,4,128,8,127,6,126,4,122,8,34,1$.

\section{3-Fenil-2H-azirin $(( \pm)-270 \mathbf{j})$}

${ }^{1} \mathrm{H}$ NMR (500 MHz, DMSO- $\left.d_{6}\right) \delta$ 7,92 (d, $\left.J=8,1 \mathrm{~Hz}, 2 \mathrm{H}\right), 7,75-7,69(\mathrm{~m}, 1 \mathrm{H}), 7,67(\mathrm{t}, J=7,2$ $\mathrm{Hz}, 2 \mathrm{H}), 1,73$ (s, 2H); ${ }^{13} \mathrm{C}$ NMR (126 MHz, DMSO-d6) $\delta 165,6,133,8,129,9,129,8,125,4$, 19,4 . 
( \pm )-Etil-transz-1-benzoil-3-(terc-butilkarbamoil)-3-metilaziridin-2-karboxilát (( \pm )-281\{1\}) ${ }^{1} \mathrm{H}$ NMR $\left(500 \mathrm{MHz}, \mathrm{DMSO}-d_{6}\right) \delta 7,73(\mathrm{~d}, J=7,4 \mathrm{~Hz}, 2 \mathrm{H}), 7,56(\mathrm{t}, J=7,3 \mathrm{~Hz}, 1 \mathrm{H}), 7,46(\mathrm{t}, J$ $=7,6 \mathrm{~Hz}, 2 \mathrm{H}), 7,20(\mathrm{~s}, 1 \mathrm{H}), 4,26-4,12(\mathrm{~m}, 2 \mathrm{H}), 3,53(\mathrm{~s}, 1 \mathrm{H}), 1,71(\mathrm{~s}, 3 \mathrm{H}), 1,23(\mathrm{t}, J=7,1 \mathrm{~Hz}$, $3 \mathrm{H}), 0,96$ (s, 9H); ${ }^{13} \mathrm{C}$ NMR $\left(126 \mathrm{MHz}, \mathrm{DMSO}-d_{6}\right) \delta$ 174,8, 166,7, 164,5, 133,3, 132,5, 128,5, 128,0, 61,5, 51,5, 49,8, 42,9, 27,7, 14,1, 13,7; HRMS (ESI) 333,1817 [M+H] ${ }^{+}$(kalkulált: $333,1814)$.

( \pm )-Etil-cisz-1-benzoil-3-(terc-butilkarbamoil)-3-metilaziridin-2-karboxilát (( \pm$)$-282\{1\})

${ }^{1} \mathrm{H}$ NMR $\left(500 \mathrm{MHz}\right.$, DMSO- $\left.d_{6}\right) \delta 8,13(\mathrm{~d}, J=7,6 \mathrm{~Hz}, 2 \mathrm{H}), 7,67(\mathrm{t}, J=7,3 \mathrm{~Hz}, 1 \mathrm{H}), 7,55(\mathrm{t}, J$ $=7,5 \mathrm{~Hz}, 2 \mathrm{H}), 7,27(\mathrm{~s}, 1 \mathrm{H}), 4,24-4,06(\mathrm{~m}, 2 \mathrm{H}), 3,52(\mathrm{~s}, 1 \mathrm{H}), 1,29(\mathrm{~s}, 3 \mathrm{H}), 1,25(\mathrm{~s}, 9 \mathrm{H}), 1,24$ $-1,21$ (m, 3H, izocianiddal átfedésben); ${ }^{13} \mathrm{C}$ NMR (126 MHz, DMSO- $\left.d_{6}\right) \delta 174,5,166,2,165,0$, 133,6, 132,5, 128,9, 128,8, 61,5, 50,9, 50,6, 45,1, 28,2, 17,7, 14,0; HRMS (ESI) 333,1815 $[\mathrm{M}+\mathrm{H}]^{+}$(kalkulált: 333,1814).

( \pm )-Etil-transz-3-(terc-butilkarbamoil)-1-(3-metoxibenzoil)-3-metilaziridin-2-karboxilát $(( \pm)-281\{2\})$

${ }^{1} \mathrm{H}$ NMR $\left(500 \mathrm{MHz}, \mathrm{DMSO}-d_{6}\right) \delta 7,37(\mathrm{t}, J=7,8 \mathrm{~Hz}, 1 \mathrm{H}), 7,31(\mathrm{~d}, J=7,5 \mathrm{~Hz}, 1 \mathrm{H}), 7,23$ (s, 1H), 7,21 (s, 1H), 7,12 (d, $J=7,9 \mathrm{~Hz}, 1 \mathrm{H}), 4,27-4,12(\mathrm{~m}, 2 \mathrm{H}), 3,78(\mathrm{~s}, 3 \mathrm{H}), 3,52(\mathrm{~s}, 1 \mathrm{H}), 1,69$ $(\mathrm{s}, 3 \mathrm{H}), 1,23$ (t, $J=7,1 \mathrm{~Hz}, 3 \mathrm{H}), 0,99(\mathrm{~s}, 9 \mathrm{H}) ;{ }^{13} \mathrm{C}$ NMR $\left(126 \mathrm{MHz}, \mathrm{DMSO}-d_{6}\right) \delta 174,5,166,6$, $164,5,159,2,134,7,129,7,120,4,118,8,112,4,61,5,55,3,51,5,49,7,43,0,27,8,14,1,13,8$; HRMS (ESI) 363,1922 [M+H] ${ }^{+}$(kalkulált: 363,1920).

( \pm )-Etil-transz-3-(terc-butilkarbamoil)-1-(4-hidroxibenzoil)-3-metilaziridin-2-karboxilát $(( \pm)-281\{3\})$

${ }^{1} \mathrm{H}$ NMR $\left(500 \mathrm{MHz}, \mathrm{DMSO}-d_{6}\right) \delta 10,17(\mathrm{~s}, 1 \mathrm{H}), 7,59(\mathrm{~d}, J=8,4 \mathrm{~Hz}, 2 \mathrm{H}), 7,12(\mathrm{~s}, 1 \mathrm{H}), 6,79$ (d, $J=8,5 \mathrm{~Hz}, 2 \mathrm{H}), 4,25-4,12(\mathrm{~m}, 2 \mathrm{H}), 3,54(\mathrm{~s}, 1 \mathrm{H}), 1,67(\mathrm{~s}, 3 \mathrm{H}), 1,22(\mathrm{t}, J=7,1 \mathrm{~Hz}, 3 \mathrm{H}), 0,98$ $(\mathrm{s}, 9 \mathrm{H}) ;{ }^{13} \mathrm{C}$ NMR $\left(126 \mathrm{MHz}\right.$, DMSO- $\left.d_{6}\right) \delta 174,0,166,9,164,5,161,5,130,4,124,1,115,1,61,3$, 51,4, 49,7, 42,7, 27,8, 14,1, 13,7; HRMS (ESI) 349,1767 [M+H] ${ }^{+}$(kalkulált: 349,1763).

( \pm )-Etil-transz-3-(terc-butilkarbamoil)-1-(2-klórbenzoil)-3-metilaziridin-2-karboxilát $(( \pm)-281\{4\})$

${ }^{1} \mathrm{H}$ NMR $\left(500 \mathrm{MHz}, \mathrm{DMSO}-d_{6}\right) \delta 7,69(\mathrm{~d}, J=7,6 \mathrm{~Hz}, 1 \mathrm{H}), 7,50-7,45(\mathrm{~m}, 2 \mathrm{H}), 7,44-7,37$ $(\mathrm{m}, 1 \mathrm{H}), 7,13(\mathrm{~s}, 1 \mathrm{H}), 4,24-4,11(\mathrm{~m}, 2 \mathrm{H}), 3,48(\mathrm{~s}, 1 \mathrm{H}), 1,60(\mathrm{~s}, 3 \mathrm{H}), 1,21(\mathrm{t}, J=7,1 \mathrm{~Hz}, 3 \mathrm{H})$, $1,02(\mathrm{~s}, 9 \mathrm{H}) ;{ }^{13} \mathrm{C}$ NMR $\left(126 \mathrm{MHz}, \mathrm{DMSO}-d_{6}\right) \delta 173,3,166,3,164,7,132,8,132,5,132,0,131,0$, 130,7, 127,0, 61,5, 51,5, 49,3, 43,5, 27,9, 14,1, 13,3; HRMS (ESI) 367,1427 [M+H] ${ }^{+}$(kalkulált: $367,1425)$.

$( \pm)$-Etil-transz-3-(terc-butilkarbamoil)-3-metil-1-(2-fenilacetil)-aziridin-2-karboxilát $(( \pm)$ 281\{5\})

${ }^{1} \mathrm{H}$ NMR (500 MHz, DMSO-d $) \delta$ 7,33 - 7,28 (m, 2H), 7,28 (s, 1H), 7,25 - 7,18 (m, 3H), 4,24 $-4,05(\mathrm{~m}, 2 \mathrm{H}), 3,56(\mathrm{q}, J=16,0 \mathrm{~Hz}, 2 \mathrm{H}), 3,23(\mathrm{~s}, 1 \mathrm{H}), 1,38(\mathrm{~s}, 3 \mathrm{H}), 1,29$ (s, 9H), 1,19 (t, $J=$ $7,1 \mathrm{~Hz}, 3 \mathrm{H}) ;{ }^{13} \mathrm{C}$ NMR $\left(126 \mathrm{MHz}\right.$, DMSO- $\left.d_{6}\right) \delta 179,2,166,4,165,8,134,6,129,9,128,2,126,7$, 61,3, 51,7, 49,0, 43,5, 42,66, 28,2, 14,1, 13,4; HRMS (ESI) 347,1972 [M+H] ${ }^{+}$(kalkulált: $347,1971)$.

( \pm )-Etil-transz-3-(terc-butilkarbamoil)-3-metil-1-((E)-3-(3,4,5-trimetoxifenil)-akriloil)aziridin-2-karboxilát $(( \pm)-281\{6\})$

${ }^{1} \mathrm{H}$ NMR (500 MHz, DMSO- $\left.d_{6}\right) \delta 7,37(\mathrm{~d}, J=15,9 \mathrm{~Hz}, 1 \mathrm{H}), 7,31(\mathrm{~s}, 1 \mathrm{H}), 7,01(\mathrm{~s}, 2 \mathrm{H}), 6,60(\mathrm{~d}$, $J=15,9 \mathrm{~Hz}, 1 \mathrm{H}), 4,26-4,13(\mathrm{~m}, 2 \mathrm{H}), 3,80(\mathrm{~s}, 6 \mathrm{H}), 3,68(\mathrm{~s}, 3 \mathrm{H}), 3,52(\mathrm{~s}, 1 \mathrm{H}), 1,64(\mathrm{~s}, 3 \mathrm{H})$, $1,26-1,20(\mathrm{~m}, 3 \mathrm{H}), 1,18(\mathrm{~s}, 9 \mathrm{H}) ;{ }^{13} \mathrm{C}$ NMR $\left(126 \mathrm{MHz}, \mathrm{DMSO}-d_{6}\right) \delta 173,4,166,7,164,8,153,1$, 
142,2, 139,5, 129,9, 120,6, 106,1, 61,3, 60,2, 56,2, 51,6, 49,0, 42,8, 28,1, 14,1, 13,9; HRMS (ESI) 449,2294 [M+H] $]^{+}$(kalkulált: 449,2288).

$( \pm)$-Etil-transz-3-(terc-butilkarbamoil)-3-metil-1-nikotinoil-aziridin-2-karboxilát $\quad(( \pm)$ 281\{7\})

${ }^{1} \mathrm{H}$ NMR $\left(500 \mathrm{MHz}, \mathrm{DMSO}-d_{6}\right) \delta 8,87(\mathrm{~s}, 1 \mathrm{H}), 8,73(\mathrm{~d}, J=3,7 \mathrm{~Hz}, 1 \mathrm{H}), 8,07(\mathrm{~d}, J=7,9 \mathrm{~Hz}$, $1 \mathrm{H}), 7,51(\mathrm{dd}, J=7,6,4,9 \mathrm{~Hz}, 1 \mathrm{H}), 7,32(\mathrm{~s}, 1 \mathrm{H}), 4,27-4,13(\mathrm{~m}, 2 \mathrm{H}), 3,54(\mathrm{~s}, 1 \mathrm{H}), 1,72(\mathrm{~s}, 3 \mathrm{H})$, $1,29-1,17(\mathrm{~m}, 3 \mathrm{H}), 0,97$ (s, 9H); ${ }^{13} \mathrm{C}$ NMR $\left(126 \mathrm{MHz}, \mathrm{DMSO}-d_{6}\right) \delta 173,8,166,4,164,5,153,0$, $148,6,135,6,129,2,123,8,61,6,51,6,50,0,43,11,27,7,14,1,13,7$; HRMS (ESI) 334,1767 $[\mathrm{M}+\mathrm{H}]^{+}$(kalkulált: 334,1767).

( \pm )-Etil-transz-1-acetil-3-(terc-butilkarbamoil)-3-metilaziridin-2-karboxilát $(( \pm)-281\{8\})$

${ }^{1} \mathrm{H}$ NMR $\left(500 \mathrm{MHz}, \mathrm{DMSO}-d_{6}\right) \delta$ 7,31 (s, 1H), 4,25 - 4,07 (m, 2H), 3,28 (s, 1H), 1,91 (s, 3H), $1,53(\mathrm{~s}, 3 \mathrm{H}), 1,27(\mathrm{~s}, 9 \mathrm{H}), 1,21(\mathrm{t}, J=7,1 \mathrm{~Hz}, 3 \mathrm{H}) ;{ }^{13} \mathrm{C}$ NMR $\left(126 \mathrm{MHz}, \mathrm{DMSO}-d_{6}\right) \delta 178,0$, $166,5,165,5,61,3,51,7,48,3,42,9,28,2,23,9,14,1,13,5$; HRMS (ESI) 271,1657 [M+H] ${ }^{+}$ (kalkulált: 271,1658).

$( \pm)$-Etil-transz-3-(terc-butilkarbamoil)-1-(2-klóracetil)-3-metilaziridin-2-karboxilát $\quad(( \pm)-$ 281\{9\})

${ }^{1} \mathrm{H}$ NMR $\left(500 \mathrm{MHz}, \mathrm{DMSO}-d_{6}\right) \delta 7,43(\mathrm{~s}, 1 \mathrm{H}), 4,28-4,10(\mathrm{~m}, 4 \mathrm{H}), 3,20(\mathrm{~s}, 1 \mathrm{H}), 1,60(\mathrm{~s}, 3 \mathrm{H})$, $1,26(\mathrm{~s}, 9 \mathrm{H}), 1,22(\mathrm{t}, J=7,1 \mathrm{~Hz}, 3 \mathrm{H}) ;{ }^{13} \mathrm{C}$ NMR (126 MHz, DMSO-d 6 ) $\delta 175,7,166,1,165,8$, 61,5, 51,7, 50,5, 44,0, 42,6, 28,1, 14,1, 13,7; HRMS (ESI) 305,1269 [M+H] ${ }^{+}$(kalkulált: $305,1268)$.

( \pm )-Etil-transz-3-(terc-butilkarbamoil)-3-metil-1-(2,2,2-trifluoracetil)-aziridin-2karboxilát $(( \pm)-281\{10\})$

${ }^{1} \mathrm{H}$ NMR $\left(500 \mathrm{MHz}, \mathrm{DMSO}-d_{6}\right) \delta 7,87(\mathrm{~s}, 1 \mathrm{H}), 4,31-4,12(\mathrm{~m}, 2 \mathrm{H}), 3,30(\mathrm{~s}, 1 \mathrm{H}), 1,64(\mathrm{~s}, 3 \mathrm{H})$, $1,25(\mathrm{~s}, 9 \mathrm{H}), 1,24-1,20(\mathrm{~m}, 3 \mathrm{H}) ;{ }^{13} \mathrm{C}$ NMR $\left(126 \mathrm{MHz}, \mathrm{DMSO}-d_{6}\right) \delta 166,08(\mathrm{q}, J=36,6 \mathrm{~Hz})$, $165,5,164,9,115,33$ (q, $J=287,5 \mathrm{~Hz}), 62,0,54,0,52,1,41,6,27,9,14,0,13,4$; HRMS (ESI) $325,1376[\mathrm{M}+\mathrm{H}]^{+}$(kalkulált: 325,1375).

( \pm )-Etil-transz-1-benzoil-3-metil-3-((2,4,4-trimetilpentán-2-il)-karbamoil)-aziridin-2karboxilát $(( \pm)-281\{11\})$

${ }^{1} \mathrm{H}$ NMR (500 MHz, DMSO- $\left.d_{6}\right) \delta 7,73(\mathrm{~d}, J=7,7 \mathrm{~Hz}, 2 \mathrm{H}), 7,55(\mathrm{t}, J=7,2 \mathrm{~Hz}, 1 \mathrm{H}), 7,45(\mathrm{t}, J$ $=7,5 \mathrm{~Hz}, 2 \mathrm{H}), 7,03(\mathrm{~s}, 1 \mathrm{H}), 4,29-4,09(\mathrm{~m}, 2 \mathrm{H}), 3,42(\mathrm{~s}, 1 \mathrm{H}), 1,71(\mathrm{~s}, 3 \mathrm{H}), 1,55(\mathrm{~d}, J=14,7$ $\mathrm{Hz}, 1 \mathrm{H}), 1,35$ (d, $J=14,7 \mathrm{~Hz}, 1 \mathrm{H}), 1,22$ (t, $J=7,0 \mathrm{~Hz}, 3 \mathrm{H}), 1,06$ (s, 3H), 0,99 (s, 3H), 0,80 (s, 9H); ${ }^{13} \mathrm{C}$ NMR (126 MHz, DMSO- $\left.d_{6}\right) \delta 174,9,166,6,164,4,133,7,132,4,128,5,127,9,61,4$, $55,3,50,0,49,8,42,8,31,2,31,1,28,4,28,2,14,1,13,7$; HRMS (ESI) 389,2439 [M+H] ${ }^{+}$ (kalkulált: 389,2440).

( \pm )-Etil-transz-1-benzoil-3-(ciklohexilkarbamoil)-3-metilaziridin-2-karboxilát 281 $\{12\})$

$(( \pm)-$

${ }^{1} \mathrm{H}$ NMR $\left(500 \mathrm{MHz}, \mathrm{DMSO}-d_{6}\right) \delta 7,87(\mathrm{~d}, J=7,9 \mathrm{~Hz}, 1 \mathrm{H}), 7,71(\mathrm{~d}, J=7,2 \mathrm{~Hz}, 2 \mathrm{H}), 7,56(\mathrm{t}, J$ $=7,4 \mathrm{~Hz}, 1 \mathrm{H}), 7,46(\mathrm{t}, J=7,6 \mathrm{~Hz}, 2 \mathrm{H}), 4,26-4,12(\mathrm{~m}, 2 \mathrm{H}), 3,54(\mathrm{~s}, 1 \mathrm{H}), 3,25$ (ddd, $J=14,9$, $11,5,5,9 \mathrm{~Hz}, 1 \mathrm{H}), 1,69(\mathrm{~s}, 3 \mathrm{H}), 1,58(\mathrm{dd}, J=22,6,12,7 \mathrm{~Hz}, 2 \mathrm{H}), 1,46(\mathrm{~d}, J=9,3 \mathrm{~Hz}, 2 \mathrm{H}), 1,23$ $(\mathrm{t}, J=7,1 \mathrm{~Hz}, 3 \mathrm{H}), 1,20-0,82(\mathrm{~m}, 6 \mathrm{H}) ;{ }^{13} \mathrm{C}$ NMR $\left(126 \mathrm{MHz}, \mathrm{DMSO}-d_{6}\right) \delta 174,7,166,6,164,3$, $133,3,132,5,128,6,127,9,61,5,49,3,49,0,43,1,31,5,31,4,25,1,24,8,24,7,14,1,13,6$; HRMS (ESI) 359,1972 [M+H] $]^{+}$(kalkulált: 359,1971). 
( \pm )-Etil-transz-1-benzoil-3-(benzilkarbamoil)-3-metilaziridin-2-karboxilát $(( \pm)-281\{13\})$

${ }^{1} \mathrm{H}$ NMR $\left(500 \mathrm{MHz}, \mathrm{DMSO}-d_{6}\right) \delta 8,82(\mathrm{t}, J=5,4 \mathrm{~Hz}, 1 \mathrm{H}), 7,76(\mathrm{~d}, J=7,8 \mathrm{~Hz}, 2 \mathrm{H}), 7,63(\mathrm{t}, J$ $=7,3 \mathrm{~Hz}, 1 \mathrm{H}), 7,49(\mathrm{t}, J=7,4 \mathrm{~Hz}, 2 \mathrm{H}), 7,19-7,10(\mathrm{~m}, 3 \mathrm{H}), 6,80(\mathrm{~d}, J=3,8 \mathrm{~Hz}, 2 \mathrm{H}), 4,28(\mathrm{dd}$, $J=15,2,6,6 \mathrm{~Hz}, 1 \mathrm{H}), 4,25-4,16(\mathrm{~m}, 2 \mathrm{H}), 3,96(\mathrm{dd}, J=15,2,5,0 \mathrm{~Hz}, 1 \mathrm{H}), 3,56(\mathrm{~s}, 1 \mathrm{H}), 1,74$ $(\mathrm{s}, 3 \mathrm{H}), 1,23(\mathrm{t}, J=7,0 \mathrm{~Hz}, 3 \mathrm{H}) ;{ }^{13} \mathrm{C}$ NMR $\left(126 \mathrm{MHz}, \mathrm{DMSO}-d_{6}\right) \delta 174,7,166,4,165,8,138,5$, 133,4 132,7, 128,70, 128,2, 128,0, 126,7, 126,7, 61,5, 49,0, 43,3, 42,9, 14,1, 13,7; HRMS (ESI) $367,1659[\mathrm{M}+\mathrm{H}]^{+}$(kalkulált: 367,1658).

( \pm )-Etil-transz-1-benzoil-3-metil-3-((3,4,5-trimetoxifenil)-karbamoil)-aziridin-2karboxilát $(( \pm)-281\{14\})$

${ }^{1} \mathrm{H}$ NMR $\left(500 \mathrm{MHz}, \mathrm{DMSO}-d_{6}\right) \delta 9,70(\mathrm{~s}, 1 \mathrm{H}), 7,82(\mathrm{~d}, J=7,4 \mathrm{~Hz}, 2 \mathrm{H}), 7,58(\mathrm{t}, J=7,1 \mathrm{~Hz}$, $1 \mathrm{H}), 7,49(\mathrm{t}, J=7,3 \mathrm{~Hz}, 2 \mathrm{H}), 6,66(\mathrm{~s}, 2 \mathrm{H}), 4,21(\mathrm{dd}, J=13,5,6,5 \mathrm{~Hz}, 2 \mathrm{H}), 3,68(\mathrm{~s}, 1 \mathrm{H}), 3,63$ $(\mathrm{s}, 6 \mathrm{H}), 3,57(\mathrm{~s}, 3 \mathrm{H}), 1,83(\mathrm{~s}, 3 \mathrm{H}), 1,23(\mathrm{t}, J=6,9 \mathrm{~Hz}, 3 \mathrm{H}) ;{ }^{13} \mathrm{C}$ NMR $\left(126 \mathrm{MHz}\right.$, DMSO- $\left.d_{6}\right) \delta$ $174,3,166,2,164,6,152,5,134,5,133,5,133,3,132,8,128,7,128,0,99,5,61,6,60,1,55,8,49,4$, 43,6, 14,1, 13,6; HRMS (ESI) 443,1819 [M+H] ${ }^{+}$(kalkulált: 443,1818).

$( \pm)$-Etil-transz-1-benzoil-3-metil-3-((4-nitrofenil)-karbamoil)-aziridin-2-karboxilát $\quad(( \pm)$ 281\{15\})

${ }^{1} \mathrm{H}$ NMR $\left(500 \mathrm{MHz}, \mathrm{DMSO}-d_{6}\right) \delta 10,31(\mathrm{~s}, 1 \mathrm{H}), 8,16(\mathrm{~d}, J=9,1 \mathrm{~Hz}, 2 \mathrm{H}), 7,84(\mathrm{~d}, J=7,4 \mathrm{~Hz}$, $2 \mathrm{H}), 7,73(\mathrm{~d}, J=9,1 \mathrm{~Hz}, 2 \mathrm{H}), 7,57(\mathrm{t}, J=7,3 \mathrm{~Hz}, 1 \mathrm{H}), 7,48(\mathrm{t}, J=7,6 \mathrm{~Hz}, 2 \mathrm{H}), 4,28-4,12(\mathrm{~m}$, $2 \mathrm{H}), 3,75(\mathrm{~s}, 1 \mathrm{H}), 1,87(\mathrm{~s}, 3 \mathrm{H}), 1,22(\mathrm{t}, J=7,1 \mathrm{~Hz}, 3 \mathrm{H}) ;{ }^{13} \mathrm{C}$ NMR $\left(126 \mathrm{MHz}\right.$, DMSO-$\left.d_{6}\right) \delta$ 174,0, 166,0, 165,9, 143,9, 143,2, 133,2, 132,8, 128,8, 128,0, 124,5, 120,8, 61,7, 49,5, 43,75, 14,0, 13,4; HRMS (ESI) 398,1352 [M+H] ${ }^{+}$(kalkulált: 398,1352).

( \pm )-Etil-transz-3-metil-1-(2-fenilacetil)-3-((2,4,4-trimetilpentán-2-il)-karbamoil)-aziridin2-karboxilát (( \pm -281\{16\})

${ }^{1} \mathrm{H}$ NMR (500 MHz, DMSO-d $) \delta$ 7,32 - 7,25 (m, 2H), 7,24 - 7,19 (m, 3H), 7,14 (s, 1H), 4,21 $-4,02(\mathrm{~m}, 2 \mathrm{H}), 3,57(\mathrm{q}, J=16,0 \mathrm{~Hz}, 2 \mathrm{H}), 3,14(\mathrm{~s}, 1 \mathrm{H}), 1,84(\mathrm{~d}, J=14,7 \mathrm{~Hz}, 1 \mathrm{H}), 1,56(\mathrm{~d}, J=$ $14,7 \mathrm{~Hz}, 1 \mathrm{H}), 1,39$ (s, 3H), 1,34 (s, 6H), 1,18 (t, $J=7,0 \mathrm{~Hz}, 3 \mathrm{H}), 0,94(\mathrm{~s}, 9 \mathrm{H}) ;{ }^{13} \mathrm{C}$ NMR $(126$ MHz, DMSO-d $d_{6} \delta 179,2,166,3,165,6,134,7,129,9,128,2,126,6,61,3,55,5,50,0,49,3,43,7$, 42,5, 31,4, 31,2, 29,1, 28,6, 14,1, 13,4; HRMS (ESI) 403,2599 [M+H] ${ }^{+}$(kalkulált: 403,2597).

$( \pm)$-Etil-transz-3-metil-3-(pentilkarbamoil)-1-(2-fenilacetil)-aziridin-2-karboxilát $\quad(( \pm)$ 281\{17\})

${ }^{1} \mathrm{H}$ NMR (500 MHz, DMSO- $\left.d_{6}\right) \delta 8,27(\mathrm{t}, J=4,5 \mathrm{~Hz}, 1 \mathrm{H}), 7,28(\mathrm{t}, J=7,3 \mathrm{~Hz}, 2 \mathrm{H}), 7,24-7,17$ $(\mathrm{m}, 3 \mathrm{H}), 4,23-3,98(\mathrm{~m}, 2 \mathrm{H}), 3,63-3,43(\mathrm{~m}, 2 \mathrm{H}), 3,29(\mathrm{~s}, 1 \mathrm{H}), 3,22-2,97(\mathrm{~m}, 2 \mathrm{H}), 1,51-$ $1,40(\mathrm{~m}, 2 \mathrm{H}), 1,34(\mathrm{~s}, 3 \mathrm{H}), 1,32-1,22(\mathrm{~m}, 4 \mathrm{H}), 1,19(\mathrm{t}, J=7,1 \mathrm{~Hz}, 3 \mathrm{H}), 0,84(\mathrm{t}, J=6,9 \mathrm{~Hz}$, $3 \mathrm{H}) ;{ }^{13} \mathrm{C}$ NMR $\left(126 \mathrm{MHz}, \mathrm{DMSO}-d_{6}\right) \delta 179,1,166,3,166,1,134,5,129,9,128,2,126,7,61,3$, 48,1 43,4 43,0, 28,6, 28,5, 21,8, 14,05, 13,9, 13,3; HRMS (ESI) 361,2130 [M+H] ${ }^{+}$(kalkulált: $361,2127)$.

( \pm )-Etil-transz-1-acetil-3-(ciklohexilkarbamoil)-3-metilaziridin-2-karboxilát $(( \pm)-281\{18\})$

${ }^{1} \mathrm{H}$ NMR $\left(500 \mathrm{MHz}, \mathrm{DMSO}-d_{6}\right) \delta 7,97(\mathrm{~d}, J=7,5 \mathrm{~Hz}, 1 \mathrm{H}), 4,24-4,06(\mathrm{~m}, 2 \mathrm{H}), 3,54(\mathrm{~d}, J=$ $7,5 \mathrm{~Hz}, 1 \mathrm{H}), 3,31(\mathrm{~s}, 1 \mathrm{H}), 1,89(\mathrm{~s}, 3 \mathrm{H}), 1,72(\mathrm{~d}, J=40,2 \mathrm{~Hz}, 4 \mathrm{H}), 1,56(\mathrm{~d}, J=12,4 \mathrm{~Hz}, 1 \mathrm{H})$, $1,50(\mathrm{~s}, 3 \mathrm{H}), 1,32-1,17(\mathrm{~m}, 4 \mathrm{H}), 1,20(\mathrm{t}, J=6,6 \mathrm{~Hz}, 3 \mathrm{H}), 1,15-0,97(\mathrm{~m}, 1 \mathrm{H}) ;{ }^{13} \mathrm{C}$ NMR $(126$ MHz, DMSO- $\left.d_{6}\right) \delta 178,0,166,4,165,1,61,3,49,3,47,7,43,1,32,1,31,8,25,1,24,9,24,9,23,8$, 14,1, 13,4; HRMS (ESI) 297,1815 [M+H] ${ }^{+}$(kalkulált: 297,1814). 
( \pm )-Etil-transz-3-(ciklohexilkarbamoil)-3-metil-1-(2-fenilacetil)-paziridin-2-karboxilát $(( \pm)-281\{19\})$

${ }^{1} \mathrm{H}$ NMR (500 MHz, DMSO-d $d_{6} \delta$ 7,92 (d, $\left.J=7,6 \mathrm{~Hz}, 1 \mathrm{H}\right), 7,28(\mathrm{t}, J=7,2 \mathrm{~Hz}, 2 \mathrm{H}), 7,25-7,15$ (m, 3H), 4,22 - 3,96 (m, 2H), 3,62 - 3,56 (m, 1H), 3,54 (s, 2H), 3,28 (s, 1H), 1,79-1,63 (m, $4 \mathrm{H}), 1,60-1,51(\mathrm{~m}, 1 \mathrm{H}), 1,32(\mathrm{~s}, 3 \mathrm{H}), 1,29-1,21(\mathrm{~m}, 4 \mathrm{H}), 1,19(\mathrm{t}, J=7,1 \mathrm{~Hz}, 3 \mathrm{H}), 1,14-$ $1,00(\mathrm{~m}, 1 \mathrm{H}) ;{ }^{13} \mathrm{C}$ NMR $\left(126 \mathrm{MHz}, \mathrm{DMSO}-d_{6}\right) \delta 179,2,166,3,165,3,134,6,129,9,128,2$, 126,7, 61,3, 49,4, 48,3, 43,5, 43,0, 32,1, 31,9, 25,2, 24,9, 14,1, 13,3; HRMS (ESI) 373,2130 $[\mathrm{M}+\mathrm{H}]^{+}$(kalkulált: 373,2127$)$.

( \pm )-Etil-transz-3-(ciklohexilkarbamoil)-3-metil-1-(2,4,6-trimetilbenzoil)-aziridin-2karboxilát (( \pm$)-281\{20\})$

${ }^{1} \mathrm{H}$ NMR $\left(500 \mathrm{MHz}, \mathrm{DMSO}-d_{6}\right) \delta 7,81(\mathrm{~d}, J=7,6 \mathrm{~Hz}, 1 \mathrm{H}), 6,82(\mathrm{~s}, 2 \mathrm{H}), 4,12(\mathrm{q}, J=7,1 \mathrm{~Hz}$, $2 \mathrm{H}), 3,57(\mathrm{~s}, 1 \mathrm{H}), 3,50-3,40(\mathrm{~m}, 1 \mathrm{H}), 2,28(\mathrm{~s}, 6 \mathrm{H}), 2,19(\mathrm{~s}, 3 \mathrm{H}), 1,61(\mathrm{dd}, J=32,6,16,0 \mathrm{~Hz}$, $3 \mathrm{H}), 1,57-1,41(\mathrm{~m}, 5 \mathrm{H}), 1,29(\mathrm{~s}, 2 \mathrm{H}), 1,20-1,13(\mathrm{~m}, 4 \mathrm{H}), 1,15-0,98(\mathrm{~m}, 2 \mathrm{H}) ;{ }^{13} \mathrm{C} \mathrm{NMR}$ $\left(126 \mathrm{MHz}, \mathrm{DMSO}-d_{6}\right) \delta 175,8,166,3,164,1,138,8,135,8,132,2,128,6,61,4,49,2,48,3,42,6$, $31,8,25,2,24,9,24,8,20,6,20,0,14,0,13,4$; HRMS (ESI) 401,2442 [M+H] ${ }^{+}$(kalkulált: $401,2440)$.

\section{( \pm )-Etil-transz-3-(ciklohexilkarbamoil)-1-(3-fluorbenzoil)-3-metilaziridin-2-karboxilát $(( \pm)-281\{21\})$}

${ }^{1} \mathrm{H}$ NMR $\left(500 \mathrm{MHz}, \mathrm{DMSO}-d_{6}\right) \delta$ 7,94 (d, $\left.J=7,9 \mathrm{~Hz}, 1 \mathrm{H}\right), 7,58-7,49$ (m, 2H), 7,45 - 7,39 (m, 2H), 4,27 - 4,14 (m, 2H), 3,54 (s, 1H), 3,29-3,20 (m, 1H), 1,69 (s, 3H), 1,65-1,53 (m, 2H), 1,48 (s, 2H), 1,22 (t, $J=7,1 \mathrm{~Hz}, 3 \mathrm{H}), 1,19-0,82(\mathrm{~m}, 6 \mathrm{H}) ;{ }^{13} \mathrm{C}$ NMR (126 MHz, DMSO$\left.d_{6}\right) \delta 173,7,166,4,164,3,161,9(\mathrm{~d}, J=245,0 \mathrm{~Hz}), 135,7(\mathrm{~d}, J=6,8 \mathrm{~Hz}), 130,9(\mathrm{~d}, J=7,7 \mathrm{~Hz})$, $124,0,119,5(\mathrm{~d}, J=21,1 \mathrm{~Hz}), 114,3(\mathrm{~d}, J=22,7 \mathrm{~Hz}), 61,6,49,4,49,1,43,2,31,5,25,0,24,8$, 24,7, 14,1, 13,6; HRMS (ESI) 377,1876 [M+H] ${ }^{+}$(kalkulált: 377,1877).

( \pm )-Etil-transz-3-(benzilkarbamoil)-3-metil-1-(2-fenilacetil)-aziridin-2-karboxilát $\quad(( \pm)$ $281\{22\})$

${ }^{1} \mathrm{H}$ NMR $\left(500 \mathrm{MHz}, \mathrm{CDCl}_{3}\right) \delta 7,51-6,85(\mathrm{~m}, 10 \mathrm{H}), 6,35-6,26(\mathrm{~m}, 1 \mathrm{H}), 4,64-4,28(\mathrm{~m}, 2 \mathrm{H})$, $4,27-4,08(\mathrm{~m}, 2 \mathrm{H}), 3,70(\mathrm{dd}, J=39,2,16,5 \mathrm{~Hz}, 2 \mathrm{H}), 3,37$ (s, 1H), 1,45 (s, 3H), 1,28 (t, $J=7,1$ $\mathrm{Hz}, 3 \mathrm{H}) ;{ }^{13} \mathrm{C}$ NMR $\left(126 \mathrm{MHz}, \mathrm{CDCl}_{3}\right) \delta 177,9,166,8,165,6,136,8,133,5,129,5,128,5,128,1$, $127,5,127,5,126,6,61,6,47,0,43,9,43,8,43,5,13,7,11,6$; HRMS (ESI) 381,1814 [M+H] ${ }^{+}$ (kalkulált: 381,1814).

( \pm )-Etil-transz-3-(benzilkarbamoil)-1-(3-metoxibenzoil)-3-metilaziridin-2-karboxilát (( \pm )281\{23\})

${ }^{1} \mathrm{H}$ NMR (500 MHz, DMSO- $\left.d_{6}\right) \delta 8,84(\mathrm{~s}, 1 \mathrm{H}), 7,45-7,29(\mathrm{~m}, 2 \mathrm{H}), 7,27-7,17$ (m, 2H), 7,17 $-7,08(\mathrm{~m}, 3 \mathrm{H}), 6,80(\mathrm{~s}, 2 \mathrm{H}), 4,30(\mathrm{~d}, J=12,8 \mathrm{~Hz}, 1 \mathrm{H}), 4,25-4,15(\mathrm{~m}, 2 \mathrm{H}), 3,96(\mathrm{~d}, J=13,6$ $\mathrm{Hz}, 1 \mathrm{H}), 3,76(\mathrm{~s}, 3 \mathrm{H}), 3,55$ (s, 1H), 1,72 (s, 3H), 1,23 (t, $J=7,4 \mathrm{~Hz}, 3 \mathrm{H}) ;{ }^{13} \mathrm{C}$ NMR $(126 \mathrm{MHz}$, DMSO- $\left.d_{6}\right) \delta 174,4,166,4,165,7,159,2,138,5,134,7,129,9,128,1,126,7,126,7,120,3,118,9$, 112, 5, 61,6, 55,3, 49,0, 43,3, 42,9, 14,1, 13,8; HRMS (ESI) 397,1764 [M+H] ${ }^{+}$(kalkulált: 397,1763).

( \pm -Etil-transz-1-acetil-3-metil-3-((3,4,5-trimetoxifenil)-karbamoil)-aziridin-2-karboxilát (( \pm$)-281\{24\})$

${ }^{1} \mathrm{H}$ NMR $\left(500 \mathrm{MHz}, \mathrm{CDCl}_{3}\right) \delta 7,96(\mathrm{~s}, 1 \mathrm{H}), 6,81(\mathrm{~s}, 2 \mathrm{H}), 4,27$ (q, $\left.J=7,4 \mathrm{~Hz}, 2 \mathrm{H}\right), 3,83(\mathrm{~s}, 6 \mathrm{H})$, $3,80(\mathrm{~s}, 3 \mathrm{H}), 3,45(\mathrm{~s}, 1 \mathrm{H}), 2,18(\mathrm{~s}, 3 \mathrm{H}), 1,75(\mathrm{~s}, 3 \mathrm{H}), 1,31(\mathrm{t}, J=6,7 \mathrm{~Hz}, 3 \mathrm{H}) ;{ }^{13} \mathrm{C} \mathrm{NMR}(126$ $\left.\mathrm{MHz}, \mathrm{CDCl}_{3}\right) \delta 176,4,165,4,165,2,152,9,134,8,132,4,97,3,62,0,60,5,55,7,47,3,43,6,24,0$, 13,7, 10,7; HRMS (ESI) 381,1662 [M+H] ${ }^{+}$(kalkulált: 381,1662). 
( () -Etil-transz-3-metil-1-(2-fenilacetil)-3-((3,4,5-trimetoxifenil)-karbamoil)-aziridin-2karboxilát $(( \pm)-281\{25\})$

${ }^{1} \mathrm{H}$ NMR $\left(500 \mathrm{MHz}, \mathrm{CDCl}_{3}\right) \delta$ 7,76 (s, 1H), 7,36 - 7,20 (m, 5H), 6,73 (s, 2H), 4,23 (dd, $J=$ $13,5,6,6 \mathrm{~Hz}, 2 \mathrm{H}), 3,81$ (s, 6H), 3,79 (s, 3H), 3,78 - 3,68 (m, 2H), 3,37 (s, 1H), 1,60 (s, 3H), $1,29(\mathrm{t}, J=7,2 \mathrm{~Hz}, 3 \mathrm{H}) ;{ }^{13} \mathrm{C} \mathrm{NMR}\left(126 \mathrm{MHz}, \mathrm{CDCl}_{3}\right) \delta 177,5,165,3,165,1,152,9,134,8$, $133,4,132,5,129,4,128,2,126,8,97,3,60,5,55,7,47,4,43,6,29,2,13,7,11,1$; HRMS (ESI) $457,1977[\mathrm{M}+\mathrm{H}]^{+}$(kalkulált: 457,1975).

( \pm -Etil-transz-3-metil-1-(4-(trifluormetil)-benzoil)-3-((3,4,5-trimetoxifenil)-karbamoil)aziridin-2-karboxilát $(( \pm)-281\{26\})$

${ }^{1} \mathrm{H}$ NMR $\left(500 \mathrm{MHz}, \mathrm{DMSO}-d_{6}\right) \delta 9,75(\mathrm{~s}, 1 \mathrm{H}), 8,01(\mathrm{~d}, J=7,6 \mathrm{~Hz}, 2 \mathrm{H}), 7,87(\mathrm{~d}, J=7,6 \mathrm{~Hz}$, 2H), 6,66 (s, 2H), 4,22 (d, J=6,7 Hz, 2H), 3,70 (s, 1H), 3,63 (s, 6H), 3,57 (s, 3H), 1,85 (s, 3H), $1,22(\mathrm{t}, J=6,7 \mathrm{~Hz}, 3 \mathrm{H}) ;{ }^{13} \mathrm{C}$ NMR $\left(126 \mathrm{MHz}, \mathrm{DMSO}-d_{6}\right) \delta 173,5,166,0,164,6,152,5,137,1$, $134,6,133,4,132,2$ (q, $J=31,8 \mathrm{~Hz}) 128,8,125,8,99,35,61,8,60,1,55,7,49,9,43,7,14,0,13,5$; HRMS (ESI) 511,1688 [M+H] $]^{+}$(kalkulált: 511,1692).

( \pm )-Etil-transz-1-(2-klóracetil)-2,3-dimetil-3-((4-nitrofenil)-karbamoil)-aziridin-2karboxilát $(( \pm)-281\{27\})$

${ }^{1} \mathrm{H}$ NMR $\left(500 \mathrm{MHz}, \mathrm{DMSO}-d_{6}\right) \delta 10,41(\mathrm{~s}, 1 \mathrm{H}), 8,24(\mathrm{~d}, J=9,1 \mathrm{~Hz}, 2 \mathrm{H}), 7,89(\mathrm{~d}, J=9,2 \mathrm{~Hz}$, 2H), 4,41 (q, $J=15,3 \mathrm{~Hz}, 2 \mathrm{H}), 4,27-4,17(\mathrm{~m}, 2 \mathrm{H}), 3,52(\mathrm{~s}, 1 \mathrm{H}), 1,78(\mathrm{~s}, 3 \mathrm{H}), 1,24$ (t, $J=7,1$ $\mathrm{Hz}, 3 \mathrm{H}) ;{ }^{13} \mathrm{C}$ NMR $(126 \mathrm{MHz}$, DMSO-d $) \delta 175,1,166,5,165,6,144,0,143,3,124,7,120,9$, 61,8, 50,1, 44,1, 43,0, 14,1, 13,4; HRMS (ESI) 370,0804 [M+H] ${ }^{+}$(kalkulált: 370,0806).

( \pm -Etil-transz-1-(3-fluorbenzoil)-3-metil-3-((4-nitrofenil)-karbamoil)-aziridin-2karboxilát (( \pm$)-281\{28\})$

${ }^{1} \mathrm{H}$ NMR $\left(500 \mathrm{MHz}, \mathrm{DMSO}-d_{6}\right) \delta 10,34(\mathrm{~s}, 1 \mathrm{H}), 8,17(\mathrm{~d}, J=8,3 \mathrm{~Hz}, 2 \mathrm{H}), 7,75(\mathrm{~d}, J=8,3 \mathrm{~Hz}$, 2H), 7,68 (d, $J=7,0 \mathrm{~Hz}, 1 \mathrm{H}), 7,62-7,52(\mathrm{~m}, 2 \mathrm{H}), 7,44(\mathrm{t}, J=7,1 \mathrm{~Hz}, 1 \mathrm{H}), 4,28-4,12(\mathrm{~m}$, $2 \mathrm{H}), 3,79(\mathrm{~s}, 1 \mathrm{H}), 1,86(\mathrm{~s}, 3 \mathrm{H}), 1,21(\mathrm{t}, J=6,3 \mathrm{~Hz}, 3 \mathrm{H}) ;{ }^{13} \mathrm{C}$ NMR $\left(126 \mathrm{MHz}\right.$, DMSO-$\left.d_{6}\right) \delta$ $172,83,165,82$ (d, $J=10,4 \mathrm{~Hz}), 162,93,160,98,143,89,143,20,135,65$ (d, $J=6,9 \mathrm{~Hz}), 131,09$ (d, $J=7,6 \mathrm{~Hz}), 124,58,124,10,120,73,119,80$ (d, $J=21,1 \mathrm{~Hz}), 114,48$ (d, $J=22,9 \mathrm{~Hz}), 61,82$, 49,66, 43,74, 14,01, 13,26; HRMS (ESI) 416,1257 [M+H] ${ }^{+}$(kalkulált: 416,1258).

$( \pm)$-terc-Butil-transz-1-benzoil-3-(terc-butilkarbamoil)-3-metilaziridin-2-karboxilát $\quad(( \pm)$ 281\{29\})

${ }^{1} \mathrm{H}$ NMR (500 MHz, DMSO- $\left.d_{6}\right) \delta 7,73(\mathrm{~d}, J=7,4 \mathrm{~Hz}, 2 \mathrm{H}), 7,55(\mathrm{t}, J=7,1 \mathrm{~Hz}, 1 \mathrm{H}), 7,46(\mathrm{t}, J$ $=7,3 \mathrm{~Hz}, 2 \mathrm{H}), 7,13(\mathrm{~s}, 1 \mathrm{H}), 3,44(\mathrm{~s}, 1 \mathrm{H}), 1,70(\mathrm{~s}, 3 \mathrm{H}), 1,43(\mathrm{~s}, 9 \mathrm{H}), 0,96(\mathrm{~s}, 9 \mathrm{H}) ;{ }^{13} \mathrm{C}$ NMR $(126$ MHz, DMSO- $\left.d_{6}\right) \delta 174,7,165,7,164,7,133,4,132,5,128,5,128,0,82,4,51,4,49,2,43,7,27,8$, 27,7, 13,3; HRMS (ESI) 361,2127 [M+H] $]^{+}$(kalkulált: 361,2127).

$( \pm)$-terc-Butil-transz-1-acetil-3-(ciklohexilkarbamoil)-3-metilaziridin-2-karboxilát $\quad(( \pm)$ 281\{30\})

${ }^{1} \mathrm{H}$ NMR $\left(500 \mathrm{MHz}, \mathrm{DMSO}-d_{6}\right) \delta$ 7,93 (d, $\left.J=7,6 \mathrm{~Hz}, 1 \mathrm{H}\right), 3,59-3,44(\mathrm{~m}, 1 \mathrm{H}), 3,22(\mathrm{~s}, 1 \mathrm{H})$, 1,87 (s, 3H), 1,75 - 1,64 (m, 4H), 1,61 - 1,53 (m, 1H), 1,50 (s, 3H), 1,42 (s, 9H), 1,35 - 1,13 $(\mathrm{m}, 4 \mathrm{H}), 1,13-0,94(\mathrm{~m}, 1 \mathrm{H}) ;{ }^{13} \mathrm{C}$ NMR $\left(126 \mathrm{MHz}, \mathrm{DMSO}-d_{6}\right) \delta 178,0,165,6,165,3,82,2$, 49,3, 47,4, 43,8, 32,1, 31,8, 27,7, 25,1, 24,9, 24,9, 23,8, 13,1; HRMS (ESI) 325,2129 [M+H] (kalkulált: 325,2127 ).

$( \pm)$-terc-Butil-transz-1-benzoil-3-(benzilkarbamoil)-3-metilaziridin-2-karboxilát $\quad(( \pm)$ 281\{31\})

${ }^{1} \mathrm{H}$ NMR $\left(500 \mathrm{MHz}, \mathrm{DMSO}-d_{6}\right) \delta 8,78(\mathrm{t}, J=5,2 \mathrm{~Hz}, 1 \mathrm{H}), 7,76(\mathrm{~d}, J=7,4 \mathrm{~Hz}, 2 \mathrm{H}), 7,62(\mathrm{t}, J$ $=7,2 \mathrm{~Hz}, 1 \mathrm{H}), 7,48(\mathrm{t}, J=7,5 \mathrm{~Hz}, 2 \mathrm{H}), 7,18-7,08(\mathrm{~m}, 3 \mathrm{H}), 6,86-6,72(\mathrm{~m}, 2 \mathrm{H}), 4,29(\mathrm{dd}, J=$ 
15,1, 6,6 Hz, 1H), 3,96 (dd, $J=15,1,4,8 \mathrm{~Hz}, 1 \mathrm{H}), 3,30(\mathrm{~s}, 1 \mathrm{H}), 1,72(\mathrm{~s}, 3 \mathrm{H}), 1,43(\mathrm{~s}, 9 \mathrm{H}) ;{ }^{13} \mathrm{C}$ NMR (126 MHz, DMSO-d6) $\delta 174,5,165,9,165,5,138,5,133,5,132,7,128,7,128,2,127,9$, 126,7, 82,5, 48,6, 44,1, 42,9, 27,7, 13,4; HRMS (ESI) 395,1973 [M+H] ${ }^{+}$(kalkulált: 395,1971).

( \pm )-terc-Butil-transz-3-metil-3-((3,4,5-trimetoxifenil)-karbamoil)-1-(2,4,6trimetilbenzoil)-aziridin-2-karboxilát $(( \pm)-281\{32\})$

${ }^{1} \mathrm{H}$ NMR (500 MHz, DMSO- $\left.d_{6}\right) \delta 9,66(\mathrm{~s}, 1 \mathrm{H}), 6,91(\mathrm{~s}, 2 \mathrm{H}), 6,83(\mathrm{~s}, 2 \mathrm{H}), 3,71(\mathrm{~s}, 6 \mathrm{H}), 3,61(\mathrm{~s}$, $3 \mathrm{H}), 3,57(\mathrm{~s}, 1 \mathrm{H}), 2,31(\mathrm{~s}, 6 \mathrm{H}), 2,18(\mathrm{~s}, 3 \mathrm{H}), 1,67(\mathrm{~s}, 3 \mathrm{H}), 1,40(\mathrm{~s}, 9 \mathrm{H}) ;{ }^{13} \mathrm{C} \mathrm{NMR}(126 \mathrm{MHz}$, DMSO- $\left.d_{6}\right) \delta 175,9,165,2,164,3,152,5,138,9,135,9,134,4,133,9,132,1,128,8,99,2,82,5$, 60,1 55,8, 48,7, 43,5, 27,6, 20,6, 20,0, 13,2; HRMS (ESI) 513,2592 [M+H] ${ }^{+}$(kalkulált: $513,2601)$.

( \pm )-Etil-transz-1-benzoil-3-(terc-butilkarbamoil)-2,3-dimetilaziridin-2-karboxilát és $( \pm)$ etil-cisz-1-benzoil-3-(terc-butilkarbamoil)-2,3-dimetilaziridin-2-karboxilát $(( \pm)-281\{33\}+$ $( \pm)-282\{33\})$

${ }^{1} \mathrm{H}$ NMR (500 MHz, DMSO- $\left.d_{6}\right)$ transz diasztereomer: $\delta 7,79(\mathrm{~d}, J=7,2 \mathrm{~Hz}, 2 \mathrm{H}), 7,54(\mathrm{t}, J=$ $7,5 \mathrm{~Hz}, 1 \mathrm{H}), 7,47$ (t, $J=7,6 \mathrm{~Hz}, 2 \mathrm{H}), 7,40(\mathrm{~s}, 1 \mathrm{H}), 3,96$ (dddd, $J=17,9,10,8,7,1,3,8 \mathrm{~Hz}, 2 \mathrm{H}$ ), $1,57(\mathrm{~s}, 3 \mathrm{H}), 1,54(\mathrm{~s}, 3 \mathrm{H}), 1,26(\mathrm{~s}, 9 \mathrm{H}), 1,00(\mathrm{t}, J=7,1 \mathrm{~Hz}, 1 \mathrm{H})$, cisz diasztereomer: $\delta 8,03-$ 7,99 (m, 2H), 7,62 (t, $J=7,4 \mathrm{~Hz}, 1 \mathrm{H}), 7,51$ (t, $J=7,8 \mathrm{~Hz}, 2 \mathrm{H}), 7,11$ (s, 1H), 4,19-4,04 (m, $2 \mathrm{H}), 1,39(\mathrm{~s}, 3 \mathrm{H}), 1,37(\mathrm{~s}, 3 \mathrm{H}), 1,23(\mathrm{~s}, 9 \mathrm{H}), 1,19(\mathrm{t}, J=7,1 \mathrm{~Hz}, 3 \mathrm{H}) ;{ }^{13} \mathrm{C}$ NMR $(126 \mathrm{MHz}$, DMSO- $\left.d_{6}\right) \delta$ disztereomer keverék: $172,5,172,4,168,2,167,2,166,8,166,3,134,7,133,6$, $133,1,132,1,128,7,128,5,128,3,127,7,61,6,61,6,51,0,50,9,50,5,49,8,28,3,28,1,16,0$, 13,9, 13,9, 13,8; HRMS (ESI) 347,1971 [M+H] ${ }^{+}$(kalkulált: 347,1971).

( \pm )-Etil-transz-1-benzoil-3-(ciklohexilkarbamoil)-2,3-dimetilaziridin-2-karboxilát $\quad(( \pm)$ 281\{34\})

${ }^{1} \mathrm{H}$ NMR (500 MHz, DMSO- $\left.d_{6}\right) \delta 7,91(\mathrm{~d}, J=8,3 \mathrm{~Hz}, 1 \mathrm{H}), 7,77(\mathrm{~d}, J=7,6 \mathrm{~Hz}, 2 \mathrm{H}), 7,54(\mathrm{t}, J$ $=7,3 \mathrm{~Hz}, 1 \mathrm{H}), 7,47(\mathrm{t}, J=7,5 \mathrm{~Hz}, 2 \mathrm{H}), 4,10-3,87(\mathrm{~m}, 2 \mathrm{H}), 3,62-3,47(\mathrm{~m}, 1 \mathrm{H}), 1,70-1,61$ $(\mathrm{m}, 4 \mathrm{H}), 1,55(\mathrm{~s}, 3 \mathrm{H}), 1,54(\mathrm{~s}, 4 \mathrm{H}), 1,32-1,16(\mathrm{~m}, 4 \mathrm{H}) 1,10-1,02(\mathrm{~m}, 1 \mathrm{H}), 1,01(\mathrm{t}, J=7,0 \mathrm{~Hz}$, $3 \mathrm{H}) ;{ }^{13} \mathrm{C}$ NMR $\left(126 \mathrm{MHz}\right.$, DMSO- $\left.d_{6}\right) \delta 172,6,167,3,166,2,134,9,132,1,128,4,127,7,61,7$, 48,3, 32,2, 25,2,24,9, 24,9, 15,7, 13,8, 12,9; HRMS (ESI) 373,2129 [M+H] ${ }^{+}$(kalkulált: $373,2127)$.

( \pm )-Etil-transz-3-(benzilkarbamoil)-1-(3-metoxibenzoil)-2,3-dimetilaziridin-2-karboxilát és ( \pm )-etil-cisz-3-(benzilkarbamoil)-1-(3-metoxibenzoil)-2,3-dimetilaziridin-2-karboxilát $(( \pm)-281\{35\}+( \pm)-282\{35\})$

${ }^{1} \mathrm{H}$ NMR $\left(500 \mathrm{MHz}, \mathrm{DMSO}-d_{6}\right) \delta$ diasztereomer keverék: 8,73 (t, $\left.J=6,2 \mathrm{~Hz}, 1 \mathrm{H}\right), 8,55(\mathrm{t}, J=$ $6,1 \mathrm{~Hz}, 1 \mathrm{H}), 7,63-7,58(\mathrm{~m}, 1 \mathrm{H}), 7,57(\mathrm{~d}, J=7,7 \mathrm{~Hz}, 1 \mathrm{H}), 7,45-7,40(\mathrm{~m}, 1 \mathrm{H}), 7,39(\mathrm{t}, J=7,8$ $\mathrm{Hz}, 2 \mathrm{H}), 7,34(\mathrm{~s}, 1 \mathrm{H}), 7,34-7,30(\mathrm{~m}, 1 \mathrm{H}), 7,30-7,21(\mathrm{~m}, 8 \mathrm{H}), 7,21-7,07(\mathrm{~m}, 3 \mathrm{H}), 4,31-$ 4,26 (m, 2H), 4,24 (d, $J=6,1 \mathrm{~Hz}, 2 \mathrm{H}), 3,99(\mathrm{q}, J=7,1 \mathrm{~Hz}, 2 \mathrm{H}), 3,92(\mathrm{qt}, J=6,7,3,3 \mathrm{~Hz}, 2 \mathrm{H})$, $3,77(\mathrm{~s}, 3 \mathrm{H}), 3,75(\mathrm{~s}, 3 \mathrm{H}), 1,58(\mathrm{~s}, 3 \mathrm{H}), 1,53(\mathrm{~s}, 3 \mathrm{H}), 1,42(\mathrm{~s}, 3 \mathrm{H}), 1,37(\mathrm{~s}, 3 \mathrm{H}) ;{ }^{13} \mathrm{C}$ NMR $(126$ MHz, DMSO- $\left.d_{6}\right) \delta$ diasztereomer keverék: 172,4, 172,3, 168,1, 167,3, 167,3, 167,2, 159,2, $159,1,139,2,139,2,136,2,135,1,129,8,129,7,128,3,128,2,127,6,127,5,126,9,126,8,120,6$, $120,0,119,2,118,0,113,0,112,5,61,8,61,3,55,3,55,3,50,6,49,7,42,5,42,5,15,7,14,1,13,8$, 13,8; HRMS (ESI) 411,1924 [M+H] ${ }^{+}$(kalkulált: 411,1920).

( \pm )-Etil-transz-1-benzoil-2-benzil-3-(terc-butilkarbamoil)-3-metilaziridin-2-karboxilát $(( \pm)-281\{36\})$

${ }^{1} \mathrm{H}$ NMR (500 MHz, DMSO- $\left.d_{6}\right) \delta 7,69-7,56(\mathrm{~m}, 3 \mathrm{H}), 7,46(\mathrm{t}, J=7,6 \mathrm{~Hz}, 1 \mathrm{H}), 7,39-7,33(\mathrm{~m}$, $2 \mathrm{H}), 7,32-7,21(\mathrm{~m}, 5 \mathrm{H}), 4,03-3,88(\mathrm{~m}, 2 \mathrm{H}), 3,51(\mathrm{~d}, J=14,8 \mathrm{~Hz}, 1 \mathrm{H}), 2,81(\mathrm{~d}, J=14,9 \mathrm{~Hz}$, $1 \mathrm{H}), 1,49(\mathrm{~s}, 3 \mathrm{H}), 1,30(\mathrm{~s}, 9 \mathrm{H}), 0,95(\mathrm{t}, J=6,9 \mathrm{~Hz}, 3 \mathrm{H}) ;{ }^{13} \mathrm{C}$ NMR $\left(126 \mathrm{MHz}, \mathrm{DMSO}-d_{6}\right) \delta$ 
$172,1,166,6,166,3,136,8,134,5,131,9,129,5,128,3,128,1,127,9,126,7,61,5,52,5,52,4$, 51,2, 35,2, 28,4, 14,5, 13,7; HRMS (ESI) 423,2287 [M+H] ${ }^{+}$(kalkulált: 423,2284).

$( \pm)$-Etil-cisz-1-benzoil-2-benzil-3-(terc-butilkarbamoil)-3-metilaziridin-2-karboxilát $(( \pm)$ 282 $\{36\})$

${ }^{1} \mathrm{H}$ NMR $\left(500 \mathrm{MHz}, \mathrm{DMSO}-d_{6}\right) \delta 7,99(\mathrm{~d}, J=7,1 \mathrm{~Hz}, 2 \mathrm{H}), 7,63(\mathrm{t}, J=7,4 \mathrm{~Hz}, 1 \mathrm{H}), 7,51(\mathrm{t}, J$ $=7,9 \mathrm{~Hz}, 2 \mathrm{H}), 7,35(\mathrm{~d}, J=7,5 \mathrm{~Hz}, 2 \mathrm{H}), 7,27-7,22(\mathrm{~m}, 2 \mathrm{H}), 7,22-7,15(\mathrm{~m}, 1 \mathrm{H}), 7,08(\mathrm{~s}, 1 \mathrm{H})$, $3,88-3,74(\mathrm{~m}, 2 \mathrm{H}), 3,28-3,10(\mathrm{~m}, 2 \mathrm{H}), 1,42(\mathrm{~s}, 3 \mathrm{H}), 1,23(\mathrm{~d}, J=2,7 \mathrm{~Hz}, 9 \mathrm{H}), 0,82(\mathrm{t}, J=7,2$ $\mathrm{Hz}, 3 \mathrm{H}) ;{ }^{13} \mathrm{C}$ NMR $\left(126 \mathrm{MHz}, \mathrm{DMSO}-d_{6}\right) \delta 172,6,166,8,166,2,135,9,133,8,133,1,129,5$, $128,7,128,4,127,9,126,6,61,0,53,2,50,9,50,6,33,9,28,1,14,8,13,4$; HRMS (ESI) 423, 2287 $[\mathrm{M}+\mathrm{H}]^{+}$(kalkulált: 423,2284).

( \pm )-transz-1-Benzoil- $N$-(terc-butil)-2,3-difenilaziridin-2-karboxamid (( \pm )-281\{37\})

${ }^{1} \mathrm{H}$ NMR $\left(500 \mathrm{MHz}, \mathrm{DMSO}-d_{6}\right) \delta 7,86(\mathrm{~d}, J=7,7 \mathrm{~Hz}, 2 \mathrm{H}), 7,57(\mathrm{t}, J=7,5 \mathrm{~Hz}, 1 \mathrm{H}), 7,44(\mathrm{t}, J$ $=7,6 \mathrm{~Hz}, 2 \mathrm{H}), 7,35-7,26(\mathrm{~m}, 4 \mathrm{H}), 7,28-7,20(\mathrm{~m}, 1 \mathrm{H}), 7,13(\mathrm{bs}, 5 \mathrm{H}), 5,90(\mathrm{~s}, 1 \mathrm{H}), 4,58(\mathrm{~s}$, 1H), $1,00(\mathrm{~s}, 9 \mathrm{H}) ;{ }^{13} \mathrm{C}$ NMR $\left(126 \mathrm{MHz}, \mathrm{DMSO}-d_{6}\right) \delta 175,7,164,3,133,8,132,9,132,7,132,0$, $129,4,128,6,128,5,128,4,128,1,128,0,127,7,127,4,57,6,51,4,49,6,27,9$; HRMS (ESI) 399,2074 [M+H] $]^{+}$(kalkulált: 399,2073).

( \pm )-transz-1-Acetil- $N$-(terc-butil)-2,3-difenilaziridin-2-karboxamid (( \pm )-281\{38\})

${ }^{1} \mathrm{H}$ NMR (500 MHz, DMSO- $\left.d_{6}\right) \delta$ 7,30 - 7,22 (m, 3H), 7,22 - 7,18 (m, 2H), 7,11 - 7,06 (m, 3H), 7,04-6,97 (m, 2H), 5,80 (s, 1H), 4,35 (s, 1H), 2,13 (s, 3H), 1,18 (s, 9H); ${ }^{13} \mathrm{C}$ NMR $(126$ MHz, DMSO- $\left.d_{6}\right) \delta 179,6,165,1,134,1,132,1,129,4,128,6,128,5,127,8,127,5,127,2,57,0$, 51,6, 48,3, 28,1, 23,7; HRMS (ESI) 337,1916 [M+H] $]^{+}$(kalkulált: 337,1916).

( \pm )-transz- $N$-Ciklohexil-2,3-difenil-1-(2,4,6-trimetilbenzoil)-aziridin-2-karboxamid $(( \pm)$ 281\{39\})

${ }^{1} \mathrm{H}$ NMR (500 MHz, DMSO- $\left.d_{6}\right) \delta$ 7,30 - 7,20 (m, 3H), 7,18 - 7,12 (m, 2H), 7,02 (q, $J=6,9$, $6,1 \mathrm{~Hz}, 3 \mathrm{H}), 6,91-6,84(\mathrm{~m}, 2 \mathrm{H}), 6,81(\mathrm{~s}, 2 \mathrm{H}), 6,51(\mathrm{~d}, J=8,2 \mathrm{~Hz}, 1 \mathrm{H}), 4,54(\mathrm{~s}, 1 \mathrm{H}), 3,75-$ $3,60(\mathrm{~m}, 1 \mathrm{H}), 2,37(\mathrm{~s}, 6 \mathrm{H}), 2,16(\mathrm{~s}, 3 \mathrm{H}), 1,72-1,40(\mathrm{~m}, 5 \mathrm{H}), 1,30-1,09(\mathrm{~m}, 5 \mathrm{H}) ;{ }^{13} \mathrm{C} \mathrm{NMR}$ $(126 \mathrm{MHz}$, DMSO-d $) \delta 177,4,164,6,138,1,134,4,133,6,133,4,132,3,129,5,128,4,128,3$, $127,7,127,6,127,1,61,7,56,6,48,8,48,7,31,7,31,6,25,0,24,5,20,6,19,6$; HRMS (ESI) 469,2761 [M+H] $]^{+}$(kalkulált: 469,2766).

( \pm )-transz-2,3-Difenil-1-(2-fenilacetil)- $N$-(3,4,5-trimetoxifenil)-aziridin-2-karboxamid $(( \pm)-281\{40\})$

${ }^{1} \mathrm{H}$ NMR (500 MHz, DMSO-d 6 ) $\delta 8,80(\mathrm{~s}, 1 \mathrm{H}), 7,33-7,19(\mathrm{~m}, 10 \mathrm{H}), 7,10-7,07(\mathrm{~m}, 3 \mathrm{H}), 7,04$ $-6,99(\mathrm{~m}, 2 \mathrm{H}), 6,96(\mathrm{~s}, 2 \mathrm{H}), 4,66(\mathrm{~s}, 1 \mathrm{H}), 3,95(\mathrm{~d}, J=16,0 \mathrm{~Hz}, 1 \mathrm{H}), 3,81(\mathrm{~d}, J=16,1 \mathrm{~Hz}, 1 \mathrm{H})$, 3,69 (s, 6H), 3,59 (s, 3H); ${ }^{13} \mathrm{C}$ NMR (126 MHz, DMSO- $\left.d_{6}\right) \delta 180,4,165,0,152,5,134,7,134,5$, $133,9,133,7,131,4,129,8,129,7,128,5,128,4,128,2,127,7,127,6,127,4,127,3,126,6,99,2$, 60,1, 57,6, 55,9, 49,4, 42,7; HRMS (ESI) 523,2227 [M+H] ${ }^{+}$(kalkulált: 523,2233).

( \pm )-transz-1-Benzoil-2-benzil- $N$-(terc-butil)-3-fenilaziridin-2-karboxamid (( \pm$)$-281\{41\})

${ }^{1} \mathrm{H}$ NMR $\left(500 \mathrm{MHz}, \mathrm{DMSO}-d_{6}\right) \delta 7,74(\mathrm{~d}, J=7,5 \mathrm{~Hz}, 2 \mathrm{H}), 7,57-7,52(\mathrm{~m}, 1 \mathrm{H}), 7,51(\mathrm{~d}, J=$ $7,5 \mathrm{~Hz}, 2 \mathrm{H}), 7,44-7,35(\mathrm{~m}, 4 \mathrm{H}), 7,33(\mathrm{t}, J=7,1 \mathrm{~Hz}, 1 \mathrm{H}), 7,20-7,10(\mathrm{~m}, 3 \mathrm{H}), 7,03(\mathrm{~d}, J=7,0$ $\mathrm{Hz}, 2 \mathrm{H}), 6,92(\mathrm{~s}, 1 \mathrm{H}), 4,41(\mathrm{~s}, 1 \mathrm{H}), 3,64(\mathrm{~d}, J=16,3 \mathrm{~Hz}, 1 \mathrm{H}), 2,97(\mathrm{~d}, J=16,2 \mathrm{~Hz}, 1 \mathrm{H}), 0,87$ (s, 9H); ${ }^{13} \mathrm{C}$ NMR (126 MHz, DMSO-d6) $\delta 176,3,164,3,136,4,134,6,133,3,132,5,128,6$, 128,5, 128,4, 128,4, 128,2, 128,0, 126, 5, 55,4, 51,0, 46,5, 32,0, 27,8; HRMS (ESI) 413,2231 $[\mathrm{M}+\mathrm{H}]^{+}$(kalkulált: 413,2229). 
( \pm )-transz-1-Acetil-2-benzil- $N$-(terc-butil)-3-fenilaziridin-2-karboxamid $(( \pm)-281\{42\})$

${ }^{1} \mathrm{H}$ NMR (500 MHz, DMSO- $\left.d_{6}\right) \delta$ 7,52 (s, 1H), 7,45 - 7,37 (m, 4H), 7,37 - 7,30 (m, 1H), 7,31 $-7,22(\mathrm{~m}, 4 \mathrm{H}), 7,23-7,17(\mathrm{~m}, 1 \mathrm{H}), 3,79(\mathrm{~s}, 1 \mathrm{H}), 3,25$ (d, $J=15,1 \mathrm{~Hz}, 1 \mathrm{H}), 2,44(\mathrm{~d}, J=15,2$ $\mathrm{Hz}, 1 \mathrm{H}), 1,65$ (s, 3H), 1,22 (s, 9H); ${ }^{13} \mathrm{C}$ NMR (126 MHz, DMSO- $\left.d_{6}\right) \delta 180,2,166,2,137,2$, $134,6,129,3,128,3,128,2,127,9,127,8,126,7,55,4,51,4,46,7,32,6,28,3,24,2$; HRMS (ESI) 351,2074 [M+H] ${ }^{+}$(kalkulált: 351,2073).

( \pm )-transz-2-Benzil- $N$-ciklohexil-3-fenil-1-(2,4,6-trimetilbenzoil)-aziridin-2-karboxamid $(( \pm)-281\{43\})$

${ }^{1} \mathrm{H}$ NMR (500 MHz, DMSO- $\left.d_{6}\right) \delta$ 7,61 (d, $\left.J=7,8 \mathrm{~Hz}, 1 \mathrm{H}\right), 7,39-7,29(\mathrm{~m}, 4 \mathrm{H}), 7,27$ (t, $J=6,6$ $\mathrm{Hz}, 1 \mathrm{H}), 7,12-7,02(\mathrm{~m}, 3 \mathrm{H}), 6,88(\mathrm{~d}, J=6,9 \mathrm{~Hz}, 2 \mathrm{H}), 6,81(\mathrm{~s}, 2 \mathrm{H}), 4,42(\mathrm{~s}, 1 \mathrm{H}), 3,48$ (d, $J=$ $16,1 \mathrm{~Hz}, 1 \mathrm{H}), 3,46-3,37(\mathrm{~m}, 1 \mathrm{H}), 2,76(\mathrm{~d}, J=16,1 \mathrm{~Hz}, 1 \mathrm{H}), 2,32(\mathrm{~s}, 6 \mathrm{H}), 2,17(\mathrm{~s}, 3 \mathrm{H}), 1,55$ $(\mathrm{d}, J=13,1 \mathrm{~Hz}, 1 \mathrm{H}), 1,52-1,41(\mathrm{~m}, 3 \mathrm{H}), 1,61-1,51(\mathrm{~m}, 1 \mathrm{H}), 1,52-1,41(\mathrm{~m}, 3 \mathrm{H}), 1,39-1,29$ $(\mathrm{m}, 1 \mathrm{H}), 1,20-1,05(\mathrm{~m}, 2 \mathrm{H}), 1,06-0,90(\mathrm{~m}, 3 \mathrm{H}) ;{ }^{13} \mathrm{C}$ NMR $\left(126 \mathrm{MHz}, \mathrm{DMSO}-d_{6}\right) \delta 177,8$, $164,2,138,1,136,3,134,6,134,2,133,5,128,4,128,4,128,3,128,0,127,9,127,6,126,2,54,1$, 48,5, 45,8, 32,1, 31,6, 25,2, 24,5, 24,4, 20,6, 19,9; HRMS (ESI) 481,2862 [M+H] ${ }^{+}$(kalkulált: $481,2855)$.

\section{( \pm )-transz-2-Benzil-3-fenil-1-(2-fenilacetil)- $N$-(3,4,5-trimetoxifenil)-aziridin-2- karboxamid (( \pm -281\{44\})}

${ }^{1} \mathrm{H}$ NMR $\left(500 \mathrm{MHz}, \mathrm{DMSO}-d_{6}\right) \delta 10,13(\mathrm{~s}, 1 \mathrm{H}), 7,48(\mathrm{~d}, J=7,7 \mathrm{~Hz}, 2 \mathrm{H}), 7,44(\mathrm{t}, J=7,4 \mathrm{~Hz}$, $2 \mathrm{H}), 7,42-7,34(\mathrm{~m}, 1 \mathrm{H}), 7,35-7,26(\mathrm{~m}, 4 \mathrm{H}), 7,27-7,15(\mathrm{~m}, 4 \mathrm{H}), 7,12(\mathrm{~d}, J=7,5 \mathrm{~Hz}, 2 \mathrm{H})$, 7,07 (s, 2H), 4,02 (s, 1H), 3,75 (s, 6H), 3,62 (s, 3H), 3,60-3,49 (m, 2H), 3,30 (s, 9H), 3,20 (d, $J=6,7 \mathrm{~Hz}, 2 \mathrm{H}) ;{ }^{13} \mathrm{C}$ NMR $\left(126 \mathrm{MHz}, \mathrm{DMSO}-d_{6}\right) \delta 181,0,166,3,152,7,137,0,135,4,134,4$, 134,2 , 134,0, 129,4, 129,3, 128,6, 128,4, 128,1, 128,0, 127,9, 127,0, 126,4, 98,13, 6,14, 6,52, 55,8, 47,3, 43,2, 32,7; HRMS (ESI) 537,2386 [M+H] ${ }^{+}$(kalkulált: 537,2389).

Etil-(2S,3S)-1-((S)-5-(terc-butoxi)-4-((terc-butoxikarbonil)-amino)-5-oxopentanoil)-3(terc-butilkarbamoil)-3-metilaziridin-2-karboxilát és etil-(2R, 3R)-1-((S)-5-(terc-butoxi)4-((terc-butoxikarbonil)-amino)-5-oxopentanoil)-3-(terc-butilkarbamoil)-3-metilaziridin2-karboxilát (281\{45\})

${ }^{1} \mathrm{H}$ NMR (500 MHz, DMSO- $\left.d_{6}\right) \delta$ 7,34, 7,32 (2 x s, 2 x $\left.1 \mathrm{H}\right), 7,12,7,09(2 \times \mathrm{d}, 2$ x $1 \mathrm{H}, J=8,3$ $\mathrm{Hz}), 4,22-4,09(\mathrm{~m}, 2 \times 2 \mathrm{H}), 3,88-3,70(\mathrm{~m}, 2 \times 1 \mathrm{H}), 3,27$ (s, $2 \times 1 \mathrm{H}), 2,39-2,25(\mathrm{~m}, 2 \times 1 \mathrm{H})$, 2,23-2,08 (m, 2 x 1H), 1,91-1,68 (m, 2 x 2H), 1,53, 1,52 (2 x s, 2 x 3H), 1,41-1,31 (m, 2 x $18 \mathrm{H}), 1,29-1,24(\mathrm{~m}, 2 \times 9 \mathrm{H}), 1,21(\mathrm{t}, J=6,8 \mathrm{~Hz}, 2 \times 3 \mathrm{H}) ;{ }^{13} \mathrm{C}$ NMR $\left(126 \mathrm{MHz}, \mathrm{DMSO}-d_{6}\right) \delta$ $180,3,180,2,171,4,171,3,166,4,166,4,165,5,165,5,155,6,155,5,80,4,80,4,78,1,61,4,53,9$, $53,6,51,7,51,6,48,4,48,4,42,7,42,6,33,4,33,0,28,2,28,2,27,6,26,0,25,9,4,1,13,6,13,6$; HRMS (ESI) 514,3125 [M+H] ${ }^{+}$(kalkulált: 514,3128).

(2S,3S)-Etil-transz-1-(3-((terc-butoxikarbonil)-amino)-propanoil)-3-(terc-

butilkarbamoil)-3-metilaziridin-2-karboxilát és $\quad(2 R, 3 R)$-etil-transz-1-(3-(tercbutoxikarbonil)-amino)-propanoil)-3-(terc-butilkarbamoil)-3-metilaziridin-2-karboxilát (281\{46\})

${ }^{1} \mathrm{H}$ NMR (500 MHz, DMSO-d $) \delta 8,55$ (s, 1H), 8,54 (s, 1H), 7,88 (d, 2 x 2H, J= 7,5 Hz), 7,78 $-7,72(\mathrm{~m}, 1 \mathrm{H}), 7,74-7,67(\mathrm{~m}, 2 \times 2 \mathrm{H}), 7,49-7,42(\mathrm{~m}, 1 \mathrm{H}), 7,40(\mathrm{t}, 2 \times 2 \mathrm{H}, J=7,5 \mathrm{~Hz}), 7,35$ $-7,26(\mathrm{~m}, 2 \times 2 \mathrm{H}), 7,27-7,20(\mathrm{~m}, 13 \mathrm{H}), 7,20-7,13(\mathrm{~m}, 17 \mathrm{H}), 7,12(\mathrm{~s}, 1 \mathrm{H}), 4,36-4,27$ (m, 2H), 4,27 - 4,18 (m, 4H), 4,17 - 4,01 (m, 6H), 3,19 (s, 1H), 2,36-2,13 (m, 4H), 2,05 - 1,88 (m, 4H), 1,74 - 1,62 (m, 2H), 1,50 - 1,44 (m, 6H), 1,24-1,19 (m, 18H), 1,19-1,12 (m, 6H); ${ }^{13} \mathrm{C}$ NMR $(126 \mathrm{MHz}$, DMSO-d $) \delta 179,7,171,4,166,2,166,0,165,5,165,5,156,0,155,8,145,0$, $144,9,143,9,143,8,140,7,128,6,127,7,127,4,127,1,126,3,125,3,125,3,120,2,69,2,67,3$, 
$65,9,61,7,61,3,55,3,55,0,51,6,46,7,32,6,32,4,28,2,28,2,27,5,22,8,14,0,13,3,13,2$; HRMS (ESI) 821,3905 [M+H] ${ }^{+}$(kalkulált: 821,3914).

( \pm )-Etil-transz-1-(3-((terc-butoxikarbonil)-amino)-propanoil)-3-(terc-butilkarbamoil)-3metilaziridin-2-karboxilát $(( \pm)-281\{47\})$

${ }^{1} \mathrm{H}$ NMR $\left(500 \mathrm{MHz}, \mathrm{DMSO}-d_{6}\right) \delta 7,35(\mathrm{~s}, 1 \mathrm{H}), 6,66(\mathrm{t}, J=6,0 \mathrm{~Hz}, 1 \mathrm{H}), 4,22-4,08(\mathrm{~m}, 2 \mathrm{H})$, $3,27(\mathrm{~s}, 1 \mathrm{H}), 3,16-3,07(\mathrm{~m}, 3 \mathrm{H}), 2,47-2,38(\mathrm{~m}, 1 \mathrm{H}), 2,27-2,19(\mathrm{~m}, 1 \mathrm{H}), 1,53(\mathrm{~s}, 3 \mathrm{H}), 1,34$ (s, 9H), 1,26 (s, 9H), 1,23 - 1,20 (m, 3H); ${ }^{13} \mathrm{C}$ NMR (126 MHz, DMSO-d $d_{6} \delta 179,2,166,4$, $165,6,155,4,77,6,61,4,51,7,48,4,42,7,36,9,35,9,28,2,28,2,14,1,13,6$; HRMS (ESI) 400,2448 [M+H] $]^{+}$(kalkulált: 400,2448).

Etil-(2S,3S)-1-((R)-2-((terc-butoxikarbonil)-amino)-2-fenilacetil)-3-(terc-butilkarbamoil)3-metilaziridin-2-karboxilát és etil-(2R,3R)-1-( $(R)-2-((t e r c-b u t o x i k a r b o n i l)-a m i n o)-2-$ fenilacetil)-3-(terc-butilkarbamoil)-3-metilaziridin-2-karboxilát (281\{48\})

${ }^{1} \mathrm{H}$ NMR $\left(500 \mathrm{MHz}\right.$, DMSO- $\left.d_{6}\right) \delta 7,82(\mathrm{~d}, J=9,7 \mathrm{~Hz}, 1 \mathrm{H}), 7,41(\mathrm{~d}, J=9,4 \mathrm{~Hz}, 1 \mathrm{H}), 7,37-7,26$ $(2 \times \mathrm{m}, 2 \times 5 \mathrm{H}), 7,24(\mathrm{~s}, 1 \mathrm{H}), 7,19(\mathrm{~s}, 1 \mathrm{H}), 5,23(\mathrm{~d}, J=9,8 \mathrm{~Hz}, 1 \mathrm{H}), 5,10(\mathrm{~d}, J=8,7 \mathrm{~Hz}, 1 \mathrm{H})$, 4,24 - 3,95 (2 x m, 2 × 2H), 3,22 (s, 1H), 3,12 (s, 1H), 1,37 (s, 9H), 1,32 (s, 9H), 1,30 (s, 9H), $1,28(\mathrm{~s}, 9 \mathrm{H}), 1,32-1,25\left(\mathrm{~m}, 2\right.$ x 3H); ${ }^{13} \mathrm{C}$ NMR (126 MHz, DMSO- $\left.d_{6}\right) \delta 178,9,178,9,166,0$, $166,0,165,7,165,6,154,8,154,7,138,8,138,5,128,3,128,1,128,0,127,7,127,4,127,3,78,5$, $78,3,61,4,59,8,58,9,51,8,51,7,49,5,49,3,43,0,42,8,28,3,28,2,28,2,28,1,14,0,13,2,12,9$; HRMS (ESI) 462,2608 [M+H] ${ }^{+}$(kalkulált: 462,2604).

( \pm )-transz-1-Benzoil- $N^{2}$-(terc-butil)- $N^{3}$-ciklopropil-2-metilaziridin-2,3-dikarboxamid $(( \pm)$ 287)

${ }^{1} \mathrm{H}$ NMR $\left(500 \mathrm{MHz}, \mathrm{CDCl}_{3}\right) \delta 7,79(\mathrm{~d}, J=7,1 \mathrm{~Hz}, 2 \mathrm{H}), 7,48(\mathrm{t}, J=7,4 \mathrm{~Hz}, 1 \mathrm{H}), 7,39(\mathrm{t}, J=7,6$ $\mathrm{Hz}, 2 \mathrm{H}), 6,53(\mathrm{~s}, 1 \mathrm{H}), 5,73(\mathrm{~s}, 1 \mathrm{H}), 3,70(\mathrm{~s}, 1 \mathrm{H}), 2,83-2,69(\mathrm{~m}, 1 \mathrm{H}), 1,65(\mathrm{~s}, 3 \mathrm{H}), 1,01(\mathrm{~s}, 9 \mathrm{H})$, $0,87-0,74(\mathrm{~m}, 2 \mathrm{H}), 0,65-0,44(\mathrm{~m}, 2 \mathrm{H}),{ }^{13} \mathrm{C} \mathrm{NMR}\left(126 \mathrm{MHz}, \mathrm{CDCl}_{3}\right) \delta 175,9,167,0,164,2$, $133,5,132,1,127,9,127,8,51,6,48,6,45,1,27,6,22,0,14,1,6,1$; HRMS (ESI) 344,1974 $[\mathrm{M}+\mathrm{H}]^{+}$(kalkulált: 344,1974).

( \pm )-transz-1-Benzoil- $N^{2}$-(terc-butil)-2-metil- $N^{3}$-(prop-2-in-1-il)-aziridin-2,3-dikarboxamid $(( \pm)-288)$

${ }^{1} \mathrm{H}$ NMR $\left(500 \mathrm{MHz}, \mathrm{DMSO}-d_{6}\right) \delta 8,80(\mathrm{t}, J=5,7 \mathrm{~Hz}, 1 \mathrm{H}), 7,73(\mathrm{~d}, J=7,1 \mathrm{~Hz}, 2 \mathrm{H}), 7,54(\mathrm{t}, J$ $=7,4 \mathrm{~Hz}, 1 \mathrm{H}), 7,45(\mathrm{t}, J=7,6 \mathrm{~Hz}, 2 \mathrm{H}), 7,09(\mathrm{~s}, 1 \mathrm{H}), 3,96-3,75(\mathrm{~m}, 2 \mathrm{H}), 3,43(\mathrm{~s}, 1 \mathrm{H}), 3,11(\mathrm{t}$, $J=2,5 \mathrm{~Hz}, 1 \mathrm{H}), 1,67$ (s, 3H), 0,96 (s, 9H); ${ }^{13} \mathrm{C}$ NMR (126 MHz, DMSO-d $d_{6} \delta 175,2,165,4$, $165,1,133,8,132,3,128,4,127,9,80,8,73,0,51,3,49,4,44,2,28,1,27,8,13,5$; HRMS (ESI) $342,1818[\mathrm{M}+\mathrm{H}]^{+}$(kalkulált: 342,1818 ).

( \pm )-transz-1-Benzoil- $N^{2}$-(terc-butil)-2-metil- $N^{3}$-fenilaziridin-2,3-dikarboxamid $(( \pm)$-289)

${ }^{1} \mathrm{H}$ NMR $\left(500 \mathrm{MHz}\right.$, DMSO- $\left.d_{6}\right) \delta 10,52(\mathrm{~s}, 1 \mathrm{H}), 7,79(\mathrm{~d}, J=7,5 \mathrm{~Hz}, 2 \mathrm{H}), 7,65(\mathrm{~d}, J=7,9 \mathrm{~Hz}$, $2 \mathrm{H}), 7,57(\mathrm{t}, J=7,4 \mathrm{~Hz}, 1 \mathrm{H}), 7,49(\mathrm{t}, J=7,5 \mathrm{~Hz}, 2 \mathrm{H}), 7,34(\mathrm{t}, J=7,9 \mathrm{~Hz}, 2 \mathrm{H}), 7,17(\mathrm{~s}, 1 \mathrm{H})$, $7,10(\mathrm{t}, J=7,4 \mathrm{~Hz}, 1 \mathrm{H}), 3,71(\mathrm{~s}, 1 \mathrm{H}), 1,77(\mathrm{~s}, 3 \mathrm{H}), 1,02(\mathrm{~s}, 9 \mathrm{H}) ;{ }^{13} \mathrm{C}$ NMR $(126 \mathrm{MHz}, \mathrm{DMSO}-$ $\left.d_{6}\right) \delta 175,7,165,7,164,5,139,0,134,3,132,8,129,3,128,9,128,4,124,3,120,0,51,81,50,1$, 45,2, 28,3, 13,7; HRMS (ESI) 380,1975 [M+H] ${ }^{+}$(kalkulált: 380,1974).

$( \pm)$-transz-1-Benzoil- $N^{2}$-ciklohexil- $N^{3}$-ciklopropil-2-metilaziridin-2,3-dikarboxamid $(( \pm)$ 290)

${ }^{1} \mathrm{H}$ NMR $\left(500 \mathrm{MHz}, \mathrm{DMSO}-d_{6}\right) \delta 8,41(\mathrm{~d}, J=3,2 \mathrm{~Hz}, 1 \mathrm{H}), 7,74(\mathrm{~d}, J=7,7 \mathrm{~Hz}, 1 \mathrm{H}), 7,70(\mathrm{~d}, J$ $=7,3 \mathrm{~Hz}, 2 \mathrm{H}), 7,53(\mathrm{t}, J=7,1 \mathrm{~Hz}, 1 \mathrm{H}), 7,44(\mathrm{t}, J=7,3 \mathrm{~Hz}, 2 \mathrm{H}), 3,38(\mathrm{~s}, 1 \mathrm{H}), 3,28-3,17(\mathrm{~m}$, $1 \mathrm{H}), 2,74-2,63(\mathrm{~m}, 1 \mathrm{H}), 1,63(\mathrm{~s}, 3 \mathrm{H}), 1,61-1,57(\mathrm{~m}, 1 \mathrm{H}), 1,58-1,51(\mathrm{~m}, 1 \mathrm{H}), 1,51-1,42$ $(\mathrm{m}, 2 \mathrm{H}), 1,27-0,84(\mathrm{~m}, 6 \mathrm{H}), 0,61(\mathrm{~d}, J=6,1 \mathrm{~Hz}, 2 \mathrm{H}), 0,52-0,38(\mathrm{~m}, 2 \mathrm{H}) ;{ }^{13} \mathrm{C}$ NMR $(126$ 
MHz, DMSO- $\left.d_{6}\right) \delta 175,1,166,4,165,1,133,9,132,2,128,4,127,9,48,9,44,5,31,6,25,1,24,9$, 24,7, 22,5, 13,2, 5,7, 5,6; HRMS (ESI) 370,2130 [M+H] (kalkulált: 370,2131).

$( \pm)$-transz-1-Benzoil- $N^{2}$-(terc-butil)- $N^{3}$-ciklobutil-2-metilaziridin-2,3-dikarboxamid $(( \pm)$ 291)

${ }^{1} \mathrm{H}$ NMR $\left(500 \mathrm{MHz}, \mathrm{CDCl}_{3}-d_{1}\right) \delta 7,83(\mathrm{~d}, J=7,7 \mathrm{~Hz}, 2 \mathrm{H}), 7,50(\mathrm{t}, J=7,3 \mathrm{~Hz}, 1 \mathrm{H}), 7,41(\mathrm{t}, J=$ $7,6 \mathrm{~Hz}, 2 \mathrm{H}), 6,54(\mathrm{~d}, J=7,9 \mathrm{~Hz}, 1 \mathrm{H}), 5,80(\mathrm{~d}, J=7,5 \mathrm{~Hz}, 1 \mathrm{H}), 4,49-4,34(\mathrm{~m}, 1 \mathrm{H}), 3,70$ (s, $1 \mathrm{H}), 3,54-3,38(\mathrm{~m}, 1 \mathrm{H}), 2,44-2,23(\mathrm{~m}, 2 \mathrm{H}), 2,02-1,84(\mathrm{~m}, 2 \mathrm{H}), 1,80-1,69(\mathrm{~m}, 3 \mathrm{H}), 1,68$ (s, 3H), 1,62 (d, $J=13,3 \mathrm{~Hz}, 1 \mathrm{H}), 1,56-1,45(\mathrm{~m}, 2 \mathrm{H}), 1,39-1,30(\mathrm{~m}, 1 \mathrm{H}), 1,29-0,98(\mathrm{~m}$, 4H), 0,85-0,71 (m, 1H); ${ }^{13} \mathrm{C}$ NMR $\left(126 \mathrm{MHz}, \mathrm{CDCl}_{3}-d_{1}\right) \delta 175,6,164,5,164,4,133,4,132,1$, $128,0,127,8,48,7,48,3,45,3,44,1,32,0,32,0,30,7,30,6,24,9,24,2,24,1,14,7,13,9$; HRMS (ESI) 384,2290 [M+H] ${ }^{+}$(kalkulált: 384,2287).

( \pm )-transz-1-benzoil- $N^{3}$-ciklopropil-2-metil- $N^{2}$-(2,4,4-trimetilpentán-2-il)-aziridin-2,3dikarboxamid $(( \pm)-292)$

${ }^{1} \mathrm{H}$ NMR $\left(500 \mathrm{MHz}, \mathrm{CDCl}_{3}-d_{1}\right) \delta 7,80(\mathrm{~d}, J=8,0 \mathrm{~Hz}, 2 \mathrm{H}), 7,49(\mathrm{t}, J=7,2 \mathrm{~Hz}, 1 \mathrm{H}), 7,39(\mathrm{t}, J=$ 7,5 Hz, 2H), 6,48 (s, 1H), 5,83 (s, 1H), 3,67 (s, 1H), 2,81-2,67 (m, 1H), 1,64 (s, 3H), 1,42 (q, $J=15,0 \mathrm{~Hz}, 2 \mathrm{H}), 1,14(\mathrm{~s}, 3 \mathrm{H}), 1,00(\mathrm{~s}, 3 \mathrm{H}), 0,87(\mathrm{~s}, 9 \mathrm{H}), 0,84-0,77(\mathrm{~m}, 2 \mathrm{H}), 0,64-0,47(\mathrm{~m}$, $2 \mathrm{H}) ;{ }^{13} \mathrm{C} \mathrm{NMR}\left(126 \mathrm{MHz}, \mathrm{CDCl}_{3}-d_{1}\right) \delta 175,9,167,0,163,9,133,7,132,1,128,0,127,8,55,7$, $52,1,48,8,45,0,31,1,31,0,27,7,27,1,22,0,14,1,6,1$; HRMS (ESI) 400,2601 [M+H] ${ }^{+}$ (kalkulált: 400,2600).

( \pm )-transz-Etil-3-(terc-butilkarbamoil)-3-metilaziridin-2-karboxilát (( \pm$)$-293)

${ }^{1} \mathrm{H}$ NMR $\left(500 \mathrm{MHz}, \mathrm{CDCl}_{3}-d_{1}\right) \delta 6,62(\mathrm{~s}, 1 \mathrm{H}), 4,24(\mathrm{qd}, J=7,1,1,5 \mathrm{~Hz}, 2 \mathrm{H}), 2,52(\mathrm{~d}, J=8,0$ $\mathrm{Hz}, 1 \mathrm{H}), 1,52(\mathrm{~s}, 3 \mathrm{H}), 1,38(\mathrm{~s}, 1 \mathrm{H}), 1,31(\mathrm{~d}, J=5,3 \mathrm{~Hz}, 12 \mathrm{H}) ;{ }^{13} \mathrm{C} \mathrm{NMR}\left(126 \mathrm{MHz}, \mathrm{CDCl}_{3}-d_{1}\right)$ $\delta 169,6,169,2,62,0,50,5,42,7,41,3,28,5,14,2,13,0$; HRMS (ESI) 229,1550 [M+H] ${ }^{+}$ (kalkulált: 229,1552).

\section{( \pm )-Etil-transz-4-(terc-butilkarbamoil)-4-metil-2-fenil-4,5-dihidrooxazol-5-karboxilát $(( \pm)-294)$}

${ }^{1} \mathrm{H}$ NMR $\left(500 \mathrm{MHz}\right.$, DMSO- $\left.d_{6}\right) \delta \delta 7,93(\mathrm{~d}, J=7,8 \mathrm{~Hz}, 2 \mathrm{H}), 7,61(\mathrm{t}, J=7,4 \mathrm{~Hz}, 1 \mathrm{H}), 7,51(\mathrm{t}, J$ $=7,6 \mathrm{~Hz}, 2 \mathrm{H}), 6,72(\mathrm{~s}, 1 \mathrm{H}), 5,40(\mathrm{~s}, 1 \mathrm{H}), 4,25-4,11(\mathrm{~m}, 2 \mathrm{H}), 1,35(\mathrm{~s}, 3 \mathrm{H}), 1,26(\mathrm{~s}, 9 \mathrm{H}), 1,24$ $-1,18(\mathrm{~m}, 3 \mathrm{H}) ;{ }^{13} \mathrm{C}$ NMR $\left(126 \mathrm{MHz}, \mathrm{DMSO}-d_{6}\right) \delta 171,6,168,2,162,3,132,5,128,9,128,3$, 126,2, 81,0, 77,8, 61,3, 50,6, 28,3, 22,0, 14,1; HRMS (ESI) 333,1815 [M+H] ${ }^{+}$(kalkulált: $333,1814)$.

( \pm )-Etil-cisz-4-(terc-butilkarbamoil)-4-metil-2-fenil-4,5-dihidrooxazol-5-karboxilát $(( \pm)$ 295)

${ }^{1} \mathrm{H}$ NMR $\left(500 \mathrm{MHz}\right.$, DMSO- $\left.d_{6}\right) \delta 7,92(\mathrm{~d}, J=7,7 \mathrm{~Hz}, 2 \mathrm{H}), 7,60(\mathrm{t}, J=7,3 \mathrm{~Hz}, 1 \mathrm{H}), 7,51(\mathrm{t}, J$ $=7,6 \mathrm{~Hz}, 2 \mathrm{H}), 6,71(\mathrm{~s}, 1 \mathrm{H}), 4,92(\mathrm{~s}, 1 \mathrm{H}), 4,13-3,98(\mathrm{~m}, 2 \mathrm{H}), 1,50(\mathrm{~s}, 3 \mathrm{H}), 1,23(\mathrm{~s}, 9 \mathrm{H}), 1,17$ $(\mathrm{t}, J=7,1 \mathrm{~Hz}, 3 \mathrm{H}) ;{ }^{13} \mathrm{C}$ NMR $\left(126 \mathrm{MHz}, \mathrm{DMSO}-d_{6}\right) \delta 170,6,168,6,162,6,132,5,128,9,128,3$, 126,1, 84,2, 78,9, 61,0, 50,3, 28,2, 27,2, 14,0; HRMS (ESI) 333,1815 [M+H] ${ }^{+}$(kalkulált: $333,1814)$.

\section{( \pm )-Etil-transz-5-(terc-butilkarbamoil)-5-metil-2-fenil-4,5-dihidrooxazol-4-karboxilát} ((土)-296)

${ }^{1} \mathrm{H}$ NMR $\left(500 \mathrm{MHz}, \mathrm{DMSO}-d_{6}\right) \delta 8,00(\mathrm{~d}, J=7,5 \mathrm{~Hz}, 2 \mathrm{H}), 7,60(\mathrm{t}, J=7,4 \mathrm{~Hz}, 1 \mathrm{H}), 7,51(\mathrm{t}, J$ $=7,6 \mathrm{~Hz}, 2 \mathrm{H}), 7,25(\mathrm{~s}, 1 \mathrm{H}), 5,05(\mathrm{~s}, 1 \mathrm{H}), 4,17(\mathrm{q}, J=7,1 \mathrm{~Hz}, 2 \mathrm{H}), 1,48(\mathrm{~s}, 3 \mathrm{H}), 1,25(\mathrm{~s}, 9 \mathrm{H})$, $1,21(\mathrm{t}, J=7,1 \mathrm{~Hz}, 3 \mathrm{H}) ;{ }^{13} \mathrm{C}$ NMR $\left(126 \mathrm{MHz}, \mathrm{DMSO}-d_{6}\right) \delta 170,7,169,0,163,7,132,3,128,8$, 128,3, 126,6, 87,0, 73,6, 61,0, 50,9, 28,2, 19,6, 14,1; HRMS (ESI) 333,1814 [M+H] ${ }^{+}$(kalkulált: $333,1814)$. 
$( \pm)$-Etil-cisz-5-(terc-butilkarbamoil)-5-metil-2-fenil-4,5-dihidrooxazol-4-karboxilát $\quad(( \pm)-$ 297)

${ }^{1} \mathrm{H}$ NMR $\left(500 \mathrm{MHz}, \mathrm{DMSO}-d_{6}\right) \delta 8,00(\mathrm{~d}, J=7,6 \mathrm{~Hz}, 2 \mathrm{H}), 7,60(\mathrm{t}, J=7,5 \mathrm{~Hz}, 1 \mathrm{H}), 7,50(\mathrm{t}, J$ $=7,6 \mathrm{~Hz}, 2 \mathrm{H}), 7,02(\mathrm{~s}, 1 \mathrm{H}), 4,61(\mathrm{~s}, 1 \mathrm{H}), 4,11-4,02(\mathrm{~m}, 1 \mathrm{H}), 4,01-3,94(\mathrm{~m}, 1 \mathrm{H}), 1,55(\mathrm{~s}, 3 \mathrm{H})$, $1,26(\mathrm{~s}, 9 \mathrm{H}), 1,16(\mathrm{t}, J=7,1 \mathrm{~Hz}, 3 \mathrm{H}) ;{ }^{13} \mathrm{C} \mathrm{NMR}\left(126 \mathrm{MHz}, \mathrm{DMSO}-d_{6}\right) \delta 169,5,169,4,163,7$, 132,3, 128,7, 128,4, 126,6, 88,1, 77,0, 60,8, 50,7, 28,2, 25,6, 13,9; HRMS (ESI) 333,1817 $[\mathrm{M}+\mathrm{H}]^{+}$(kalkulált: 333,1814).

Etil-2-benzamido-4-(terc-butilamino)-3-hidroxi-3-metil-4-oxobutanoát $\quad(( \pm)-298 a \quad$ vagy $( \pm)-298 b)$

${ }^{1} \mathrm{H}$ NMR $\left(500 \mathrm{MHz}, \mathrm{CDCl}_{3}-d_{1}\right) \delta 7,93(\mathrm{~d}, J=9,5 \mathrm{~Hz}, 1 \mathrm{H}), 7,86(\mathrm{~d}, J=7,6 \mathrm{~Hz}, 2 \mathrm{H}), 7,53(\mathrm{t}, J$ $=7,3 \mathrm{~Hz}, 1 \mathrm{H}), 7,46(\mathrm{t}, J=7,5 \mathrm{~Hz}, 2 \mathrm{H}), 6,69(\mathrm{~s}, 1 \mathrm{H}), 5,00(\mathrm{~d}, J=9,4 \mathrm{~Hz}, 1 \mathrm{H}), 4,96(\mathrm{~s}, 1 \mathrm{H}), 4,29$ $-4,14(\mathrm{~m}, 2 \mathrm{H}), 1,47(\mathrm{~s}, 3 \mathrm{H}), 1,34(\mathrm{~s}, 9 \mathrm{H}), 1,25(\mathrm{t}, J=7,2 \mathrm{~Hz}, 3 \mathrm{H}) ;{ }^{13} \mathrm{C} \mathrm{NMR}\left(126 \mathrm{MHz}, \mathrm{CDCl}_{3^{-}}\right.$ $\left.d_{1}\right) \delta 174,7,172,1,166,8,133,2,131,4,128,2,126,8,75,5,61,9,57,8,50,7,28,1,23,8,13,6$; HRMS (ESI) 351,1922 [M+H] $]^{+}$(kalkulált: 351,1920).

$( \pm)-(2 R, 3 ' R, 5 S, 6 S)$-Etil-5-metil-2'-oxo-2-fenil-1,3-diazaspiro[biciklo[3.1.0]hexán-4,3'indolin]-6-karboxilát (( \pm$)-301 a)$

${ }^{1} \mathrm{H}$ NMR $\left(500 \mathrm{MHz}, \mathrm{CDCl}_{3}\right) \delta 8,36(\mathrm{~s}, 1 \mathrm{H}), 7,58(\mathrm{~d}, J=7,4 \mathrm{~Hz}, 2 \mathrm{H}), 7,41(\mathrm{~d}, J=7,0 \mathrm{~Hz}, 1 \mathrm{H})$, 7,38 (d, $J=7,5 \mathrm{~Hz}, 2 \mathrm{H}), 7,36-7,34(\mathrm{~m}, 1 \mathrm{H}), 7,32(\mathrm{t}, J=7,6 \mathrm{~Hz}, 1 \mathrm{H}), 7,11(\mathrm{t}, J=7,6 \mathrm{~Hz}, 1 \mathrm{H})$, $6,94(\mathrm{~d}, J=7,8 \mathrm{~Hz}, 1 \mathrm{H}), 6,15(\mathrm{~s}, 1 \mathrm{H}), 4,33-4,08(\mathrm{~m}, 2 \mathrm{H}), 3,17(\mathrm{~s}, 1 \mathrm{H}), 2,50(\mathrm{~s}, 1 \mathrm{H}), 1,34$ (s, $3 \mathrm{H}), 1,25(\mathrm{t}, J=7,1 \mathrm{~Hz}, 3 \mathrm{H}) ;{ }^{13} \mathrm{C}$ NMR $\left(126 \mathrm{MHz}, \mathrm{CDCl}_{3}\right) \delta 179,1,168,9,141,7,137,6,130,1$, $128,6,128,3,126,9,126,4,124,0,123,2,110,5,79,4,71,2,61,3,56,9,35,9,14,3,10,4$; HRMS (ESI) 364,1661 [M+H] $]^{+}$(kalkulált: 364,1661).

( \pm )-(2R,3'S,5R,6R)-Etil-5-metil-2' -oxo-2-fenil-1,3-diazaspiro[biciklo[3.1.0]hexán-4,3'indolin]-6-karboxilát $(( \pm)-301 b)$

${ }^{1} \mathrm{H}$ NMR $\left(500 \mathrm{MHz}, \mathrm{DMSO}-d_{6}\right) \delta 10,65(\mathrm{~s}, 1 \mathrm{H}), 7,56-7,50(\mathrm{~m}, 3 \mathrm{H}), 7,41(\mathrm{t}, J=7,4 \mathrm{~Hz}, 2 \mathrm{H})$, 7,35 (t, $J=7,3 \mathrm{~Hz}, 1 \mathrm{H}), 7,29$ (t, $J=7,1 \mathrm{~Hz}, 1 \mathrm{H}), 7,07$ (t, $J=7,5 \mathrm{~Hz}, 1 \mathrm{H}), 6,94(\mathrm{~d}, J=7,7 \mathrm{~Hz}$, $1 \mathrm{H}), 5,77(\mathrm{~d}, J=7,4 \mathrm{~Hz}, 1 \mathrm{H}), 4,15-3,97(\mathrm{~m}, 2 \mathrm{H}), 3,65(\mathrm{~d}, J=7,5 \mathrm{~Hz}, 1 \mathrm{H}), 1,15(\mathrm{t}, J=7,1$ $\mathrm{Hz}, 3 \mathrm{H}), 0,94(\mathrm{~s}, 3 \mathrm{H}) ;{ }^{13} \mathrm{C}$ NMR $\left(126 \mathrm{MHz}, \mathrm{DMSO}-d_{6}\right) \delta 176,6,169,3,141,9,138,9,131,2$, $129,5,128,8,128,5,127,3,125,2,122,7,110,7,80,4,70,3,60,9,56,9,35,5,14,6,11,5 ;$ HRMS (ESI) $364,1663[\mathrm{M}+\mathrm{H}]^{+}$(kalkulált: 364,1661).

$( \pm)-(2 R, 3 ' R, 5 S, 6 S)$-Etil-5'-klór-5-metil-2'-oxo-2-fenil-1,3-diazaspiro[biciklo[3.1.0]hexán4,3'-indolin]-6-karboxilát (( \pm$)-302 a)$

${ }^{1} \mathrm{H}$ NMR $\left(500 \mathrm{MHz}, \mathrm{DMSO}-d_{6}\right) \delta 10,73(\mathrm{~s}, 1 \mathrm{H}), 7,56(\mathrm{~d}, J=2,2 \mathrm{~Hz}, 1 \mathrm{H}), 7,51(\mathrm{~d}, J=7,5 \mathrm{~Hz}$, $2 \mathrm{H}), 7,40(\mathrm{t}, J=7,4 \mathrm{~Hz}, 2 \mathrm{H}), 7,37-7,32(\mathrm{~m}, 2 \mathrm{H}), 6,90(\mathrm{~d}, J=8,3 \mathrm{~Hz}, 1 \mathrm{H}), 5,79(\mathrm{~d}, J=7,8$ $\mathrm{Hz}, 1 \mathrm{H}), 4,27(\mathrm{~d}, J=7,8 \mathrm{~Hz}, 1 \mathrm{H}), 4,17-4,02(\mathrm{~m}, 2 \mathrm{H}), 3,33(\mathrm{~s}, 1 \mathrm{H}), 1,16(\mathrm{t}, J=7,0 \mathrm{~Hz}, 3 \mathrm{H})$, $1,11(\mathrm{~s}, 3 \mathrm{H}) ;{ }^{13} \mathrm{C}$ NMR $\left(126 \mathrm{MHz}, \mathrm{DMSO}-d_{6}\right) \delta 178,6,169,1,142,3,138,4,129,9,128,9,128,7$, $128,4,127,4,126,3,125,5,111,7,79,6,71,7,61,1,56,4,35,3,14,6,10,6$; HRMS (ESI) 398,1275 és 400,1240 [M+H] ${ }^{+}$(kalkulált: 398,1271 és 400,1271).

$( \pm)-(2 R, 3 ' R, 5 S, 6 S)$-Etil-7'-bróm-5-metil-2'-oxo-2-fenil-1,3-

diazaspiro[biciklo[3.1.0]hexán-4,3'-indolin]-6-karboxilát $(( \pm)-303 a)$

${ }^{1} \mathrm{H}$ NMR $\left(500 \mathrm{MHz}, \mathrm{DMSO}-d_{6}\right) \delta 10,92(\mathrm{~s}, 1 \mathrm{H}), 7,56-7,45(\mathrm{~m}, 4 \mathrm{H}), 7,40(\mathrm{t}, J=7,3 \mathrm{~Hz}, 2 \mathrm{H})$, $7,38-7,31(\mathrm{~m}, 1 \mathrm{H}), 7,01(\mathrm{t}, J=7,8 \mathrm{~Hz}, 1 \mathrm{H}), 5,82(\mathrm{~d}, J=6,8 \mathrm{~Hz}, 1 \mathrm{H}), 4,35(\mathrm{~d}, J=6,9 \mathrm{~Hz}, 1 \mathrm{H})$, 4,16 - 4,00 (m, 2H), 1,18 - 1,08 (m, 6H); ${ }^{13} \mathrm{C}$ NMR (126 MHz, DMSO-d 6 ) $\delta 179,0,169,1$, $142,7,138,6,132,9,129,0,128,8,128,4,127,4,124,2,124,1,102,6,79,0,72,0,61,0,56,4,35,3$, 14,6, 10,6; HRMS (ESI) 442,0771 és 444,0749 [M+H] (kalkulált: 442,0766 és 444,0766). 
( \pm )-(2R,3' $R, 5 S, 6 S)$-Etil-5-metil-7'-nitro-2' -oxo-2-fenil-1,3-diazaspiro[biciklo[3.1.0]hexán4,3'-indolin]-6-karboxilát $(( \pm)-304 a)$

${ }^{1} \mathrm{H}$ NMR $\left(500 \mathrm{MHz}, \mathrm{DMSO}-d_{6}\right) \delta 11,37(\mathrm{~s}, 1 \mathrm{H}), 8,10(\mathrm{~d}, J=8,4 \mathrm{~Hz}, 1 \mathrm{H}), 7,91(\mathrm{~d}, J=7,1 \mathrm{~Hz}$, $1 \mathrm{H}), 7,53(\mathrm{~d}, J=7,4 \mathrm{~Hz}, 2 \mathrm{H}), 7,41(\mathrm{t}, J=7,4 \mathrm{~Hz}, 2 \mathrm{H}), 7,36(\mathrm{t}, J=7,3 \mathrm{~Hz}, 1 \mathrm{H}), 7,31-7,23$ (m, $1 \mathrm{H}), 5,85(\mathrm{~d}, J=6,7 \mathrm{~Hz}, 1 \mathrm{H}), 4,46(\mathrm{~d}, J=6,8 \mathrm{~Hz}, 1 \mathrm{H}), 4,17-4,00(\mathrm{~m}, 2 \mathrm{H}), 3,42(\mathrm{~s}, 1 \mathrm{H}), 1,17$ $-1,12(\mathrm{~m}, 6 \mathrm{H}) ;{ }^{13} \mathrm{C}$ NMR $\left(126 \mathrm{MHz}, \mathrm{DMSO}-d_{6}\right) \delta 179,5,168,9,139,8,138,4,131,6,131,3$, $130,6,128,8,128,5,127,4,125,1,122,6,79,0,69,9,61,1,56,4,35,4,14,6,10,6$; HRMS (ESI) 409,1515 [M+H] ${ }^{+}$(kalkulált: 409,1512).

$( \pm)-(2 R, 3 ' R, 5 S, 6 S)$-Etil-6'-metoxi-5-metil-2'-oxo-2-fenil-1,3-diazaspiro[biciklo[3.1.0] hexán-4,3'-indolin]-6-karboxilát (( \pm -305a)

${ }^{1} \mathrm{H}$ NMR $\left(500 \mathrm{MHz}\right.$, DMSO- $\left.d_{6}\right) \delta 10,53(\mathrm{~s}, 1 \mathrm{H}), 7,50(\mathrm{~d}, J=7,6 \mathrm{~Hz}, 2 \mathrm{H}), 7,39$ (t, $J=7,5 \mathrm{~Hz}$, $2 \mathrm{H}), 7,39-7,30(\mathrm{~m}, 2 \mathrm{H}), 6,63-6,52(\mathrm{~m}, 1 \mathrm{H}), 6,43(\mathrm{~s}, 1 \mathrm{H}), 5,77(\mathrm{~d}, J=7,7 \mathrm{~Hz}, 1 \mathrm{H}), 4,13(\mathrm{~d}$, $J=7,8 \mathrm{~Hz}, 1 \mathrm{H}), 4,11-4,03(\mathrm{~m}, 2 \mathrm{H}), 3,76(\mathrm{~s}, 3 \mathrm{H}), 3,27(\mathrm{~s}, 1 \mathrm{H}), 1,15(\mathrm{t}, J=7,1 \mathrm{~Hz}, 3 \mathrm{H}), 1,09$ $(\mathrm{s}, 3 \mathrm{H}) ;{ }^{13} \mathrm{C}$ NMR $\left(126 \mathrm{MHz}, \mathrm{DMSO}-d_{6}\right) \delta 179,4,169,3,161,1,144,6,138,8,128,7,128,3$, 127,3, 126,0, 118,4, 107,1, 97,1, 79,2, 71,3, 60,9, 56,2, 55,7, 35,3, 14,6, 10,5; HRMS (ESI) 394,1770 [M+H] $]^{+}$(kalkulált: 394,1767).

( \pm )-(2R,3' $R, 5 S, 6 S)$-Etil-1',5-dimetil-2'-oxo-2-fenil-1,3-diazaspiro[biciklo[3.1.0]hexán-4,3'indolin]-6-karboxilát (( \pm$)-306 a)$

${ }^{1} \mathrm{H}$ NMR (500 MHz, DMSO- $\left.d_{6}\right) \delta 7,52(\mathrm{t}, J=7,8 \mathrm{~Hz}, 3 \mathrm{H}), 7,42-7,37(\mathrm{~m}, 3 \mathrm{H}), 7,34(\mathrm{t}, J=7,3$ $\mathrm{Hz}, 1 \mathrm{H}), 7,17-7,05(\mathrm{~m}, 2 \mathrm{H}), 5,84(\mathrm{~d}, J=7,4 \mathrm{~Hz}, 1 \mathrm{H}), 4,26(\mathrm{~d}, J=7,5 \mathrm{~Hz}, 1 \mathrm{H}), 4,16-4,02$ $(\mathrm{m}, 2 \mathrm{H}), 3,18(\mathrm{~s}, 3 \mathrm{H}), 1,15(\mathrm{t}, J=7,1 \mathrm{~Hz}, 3 \mathrm{H}), 1,04(\mathrm{~s}, 3 \mathrm{H}),{ }^{13} \mathrm{C}$ NMR $\left(126 \mathrm{MHz}, \mathrm{DMSO}-d_{6}\right) \delta$ $177,0,169,2,144,8,138,6,130,2,128,8,128,3,127,3,126,1,124,8,123,0,109,3,79,3,71,2$, 61,0, 56,3, 35,4, 26,4, 14,6, 10,5; HRMS (ESI) 378,1820 [M+H] ${ }^{+}$(kalkulált: 378,1818).

( \pm )-(2R,3' $R, 5 S, 6 S)$-Etil-1'-benzil-5-metil-2'-oxo-2-fenil-1,3-diazaspiro[biciklo[3.1.0] hexán-4,3'-indolin]-6-karboxilát $(( \pm)-307 a)$

${ }^{1} \mathrm{H}$ NMR $\left(500 \mathrm{MHz}, \mathrm{CDCl}_{3}\right) \delta$ 7,59 (d, $\left.J=7,3 \mathrm{~Hz}, 2 \mathrm{H}\right), 7,47-7,27$ (m, 9H), 7,09 (t, $J=7,6$ $\mathrm{Hz}, 1 \mathrm{H}), 6,77(\mathrm{~d}, J=7,8 \mathrm{~Hz}, 1 \mathrm{H}), 6,22(\mathrm{~s}, 1 \mathrm{H}), 5,11(\mathrm{~d}, J=15,6 \mathrm{~Hz}, 1 \mathrm{H}), 4,78(\mathrm{~d}, J=15,6 \mathrm{~Hz}$, $1 \mathrm{H}), 4,37-4,07(\mathrm{~m}, 2 \mathrm{H}), 3,19(\mathrm{~s}, 1 \mathrm{H}), 2,51(\mathrm{~s}, 1 \mathrm{H}), 1,34(\mathrm{~s}, 3 \mathrm{H}), 1,24(\mathrm{t}, J=7,1 \mathrm{~Hz}, 3 \mathrm{H}) ;{ }^{13} \mathrm{C}$ NMR $\left(126 \mathrm{MHz}, \mathrm{CDCl}_{3}\right) \delta 176,9,168,9,143,8,137,7,135,5,130,1,128,9,128,6,128,3,127,8$, $127,4,126,9,125,9,123,7,123,2,109,7,79,5,70,9,61,3,56,9,43,9,35,9,14,3,10,6$; HRMS (ESI) 454,2127 [M+H] ${ }^{+}$(kalkulált: 454,2131).

\section{( \pm )-(2R,3'R,5S,6R)-2,5,6-Trifenil-1,3-diazaspiro[biciklo[3.1.0]hexán-4,3'-indolin]-2'-on} $(( \pm)-308 a)$

${ }^{1} \mathrm{H}$ NMR $\left(500 \mathrm{MHz}, \mathrm{CDCl}_{3}\right) \delta 7,68(\mathrm{~d}, J=7,5 \mathrm{~Hz}, 1 \mathrm{H}), 7,64(\mathrm{~d}, J=7,0 \mathrm{~Hz}, 2 \mathrm{H}), 7,40-7,28$ $(\mathrm{m}, 5 \mathrm{H}), 7,18(\mathrm{t}, J=7,6 \mathrm{~Hz}, 1 \mathrm{H}), 7,13(\mathrm{~d}, J=7,0 \mathrm{~Hz}, 2 \mathrm{H}), 7,06(\mathrm{t}, J=7,2 \mathrm{~Hz}, 2 \mathrm{H}), 7,02(\mathrm{td}, J$ $=8,1,7,6,2,7 \mathrm{~Hz}, 2 \mathrm{H}), 6,99-6,92(\mathrm{~m}, 2 \mathrm{H}), 6,78(\mathrm{~d}, J=7,7 \mathrm{~Hz}, 1 \mathrm{H}), 6,47(\mathrm{~s}, 1 \mathrm{H}), 3,85(\mathrm{~s}$, $1 \mathrm{H}), 2,87$ (bs, $1 \mathrm{H}) ;{ }^{13} \mathrm{C} \mathrm{NMR}\left(126 \mathrm{MHz}, \mathrm{CDCl}_{3}\right) \delta 178,4,141,7,138,4,135,6,132,2,130,0$, $128,5,128,0,127,7,127,7,127,6,127,5,127,5,126,9,126,7,123,4,123,0,110,3,80,5,72,4$, 64,1, 40,2; HRMS (ESI) 430,1924 [M+H] ${ }^{+}$(kalkulált: 430,1919).

( \pm )-(2R,3'R,5S,6R)-5-(4-Metoxifenil)-2,6-difenil-1,3-diazaspiro[biciklo[3.1.0]hexán-4,3'indolin]-2'-on $(( \pm)-309 a)$

${ }^{1} \mathrm{H}$ NMR (500 MHz, DMSO- $\left.d_{6}\right) \delta 10,09(\mathrm{~s}, 1 \mathrm{H}), 7,95(\mathrm{~d}, J=7,4 \mathrm{~Hz}, 1 \mathrm{H}), 7,61(\mathrm{~d}, J=7,5 \mathrm{~Hz}$, 2H), 7,38 (d, $J=7,6 \mathrm{~Hz}, 2 \mathrm{H}), 7,29(\mathrm{q}, J=8,1 \mathrm{~Hz}, 2 \mathrm{H}), 7,18-7,04(\mathrm{~m}, 5 \mathrm{H}), 7,01(\mathrm{t}, J=7,2$ $\mathrm{Hz}, 1 \mathrm{H}), 6,74(\mathrm{~d}, J=7,8 \mathrm{~Hz}, 2 \mathrm{H}), 6,70-6,65(\mathrm{~m}, 1 \mathrm{H}), 6,54(\mathrm{~d}, J=8,2 \mathrm{~Hz}, 2 \mathrm{H}), 6,21(\mathrm{~d}, J=$ $7,9 \mathrm{~Hz}, 1 \mathrm{H}), 4,39$ (d, $J=8,1 \mathrm{~Hz}, 1 \mathrm{H}), 4,15(\mathrm{~s}, 1 \mathrm{H}), 3,58(\mathrm{~s}, 3 \mathrm{H}) ;{ }^{13} \mathrm{C}$ NMR $(126 \mathrm{MHz}, \mathrm{DMSO}-$ 
$\left.d_{6}\right) \delta 178,6,158,6,143,4,139,4,137,1,129,9,128,7,128,1,128,0,128,0,127,9,127,4,126,8$, $125,4,125,3,122,2,113,1,109,9,79,9,72,4,63,4,55,2$; HRMS (ESI) 460,2032 [M+H] ${ }^{+}$ (kalkulált: 460,2025).

( \pm )-(2R,3'R,5S,6R)-5-(4-Klórfenil)-2,6-difenil-1,3-diazaspiro[biciklo[3.1.0]hexán-4,3'indolin]-2'-on (( \pm -310a)

${ }^{1} \mathrm{H}$ NMR $\left(500 \mathrm{MHz}, \mathrm{DMSO}-d_{6}\right) \delta 10,18(\mathrm{~s}, 1 \mathrm{H}), 7,99(\mathrm{~d}, J=7,4 \mathrm{~Hz}, 1 \mathrm{H}), 7,62(\mathrm{~d}, J=7,5 \mathrm{~Hz}$, $2 \mathrm{H}), 7,38(\mathrm{t}, J=7,5 \mathrm{~Hz}, 2 \mathrm{H}), 7,35-7,24(\mathrm{~m}, 2 \mathrm{H}), 7,17-7,00(\mathrm{~m}, 8 \mathrm{H}), 6,77(\mathrm{~d}, J=7,7 \mathrm{~Hz}$, 1H), 6,22 (d, $J=7,9 \mathrm{~Hz}, 1 \mathrm{H}), 4,47(\mathrm{~d}, J=8,0 \mathrm{~Hz}, 1 \mathrm{H}), 4,23(\mathrm{~s}, 1 \mathrm{H}) ;{ }^{13} \mathrm{C}$ NMR $(126 \mathrm{MHz}$, DMSO-d $d_{6} \delta 178,4,143,3,139,2,136,5,132,8,132,3,130,2,128,7,128,2,127,9,127,8,127,6$, $127,4,127,0,125,3,122,4,110,1,79,8,72,2,63,2$; HRMS (ESI) 464,1535 és 466,1496 [M+H] ${ }^{+}$ (kalkulált: 464,1530 és 466,1530).

$( \pm)-(2 R, 3 ' R, 5 S, 6 R)-5$-(4-Fluorfenil)-2,6-difenil-1,3-diazaspiro[biciklo[3.1.0]hexán-4,3'indolin]-2'-on (( \pm -311a)

${ }^{1} \mathrm{H}$ NMR $\left(500 \mathrm{MHz}, \mathrm{DMSO}-d_{6}\right) \delta 10,16(\mathrm{~s}, 1 \mathrm{H}), 7,98(\mathrm{~d}, J=7,4 \mathrm{~Hz}, 1 \mathrm{H}), 7,62(\mathrm{~d}, J=7,5 \mathrm{~Hz}$, $2 \mathrm{H}), 7,38(\mathrm{t}, J=7,5 \mathrm{~Hz}, 2 \mathrm{H}), 7,31(\mathrm{q}, J=7,1 \mathrm{~Hz}, 2 \mathrm{H}), 7,18-7,05(\mathrm{~m}, 5 \mathrm{H}), 7,01(\mathrm{t}, J=7,1 \mathrm{~Hz}$, $1 \mathrm{H}), 6,91-6,79(\mathrm{~m}, 3 \mathrm{H}), 6,76(\mathrm{~d}, J=7,8 \mathrm{~Hz}, 1 \mathrm{H}), 6,23(\mathrm{~d}, J=7,9 \mathrm{~Hz}, 1 \mathrm{H}), 4,45(\mathrm{~d}, J=8,0$ $\mathrm{Hz}, 1 \mathrm{H}), 4,21(\mathrm{~s}, 1 \mathrm{H}) ;{ }^{13} \mathrm{C}$ NMR $\left(126 \mathrm{MHz}, \mathrm{DMSO}-d_{6}\right) \delta 178,5,161,6(\mathrm{~d}, J=243,3 \mathrm{~Hz}), 143,3$, $143,3,139,2,139,2,136,7,136,7,130,2,129,8,128,7,128,1,127,8,127,7,127,4,126,9,125,3$, $122,4,114,7(\mathrm{~d}, J=21,4 \mathrm{~Hz}), 110,1,79,8,72,3,63,1$; HRMS (ESI) 448,1830 [M+H] ${ }^{+}$ (kalkulált: 448,1825).

( \pm )-(2R,3' $R, 5 S, 6 R)-5$-Benzil-2,6-difenil-1,3-diazaspiro[biciklo[3.1.0]hexán-4,3' -indolin]$2^{\prime}$-on $(( \pm)-312 a)$

${ }^{1} \mathrm{H}$ NMR $\left(500 \mathrm{MHz}, \mathrm{DMSO}-d_{6}\right) \delta 10,30(\mathrm{~s}, 1 \mathrm{H}), 7,58-7,51(\mathrm{~m}, 5 \mathrm{H}), 7,40(\mathrm{t}, J=7,5 \mathrm{~Hz}, 2 \mathrm{H})$, $7,33(\mathrm{t}, J=7,4 \mathrm{~Hz}, 2 \mathrm{H}), 7,28(\mathrm{t}, J=6,3 \mathrm{~Hz}, 2 \mathrm{H}), 6,94(\mathrm{t}, J=7,6 \mathrm{~Hz}, 1 \mathrm{H}), 6,79$ (t, $J=7,6 \mathrm{~Hz}$, $1 \mathrm{H}), 6,74(\mathrm{t}, J=7,2 \mathrm{~Hz}, 1 \mathrm{H}), 6,69(\mathrm{t}, J=7,1 \mathrm{~Hz}, 2 \mathrm{H}), 6,48(\mathrm{~d}, J=7,3 \mathrm{~Hz}, 2 \mathrm{H}), 6,38(\mathrm{~d}, J=$ 7,7 Hz, 1H), 5,96 (d, $J=8,1 \mathrm{~Hz}, 1 \mathrm{H}), 4,08$ (d, $J=8,2 \mathrm{~Hz}, 1 \mathrm{H}), 4,04$ (s, 1H), 3,04 (d, $J=15,0$ $\mathrm{Hz}, 1 \mathrm{H}), 2,75(\mathrm{~d}, J=15,1 \mathrm{~Hz}, 1 \mathrm{H}) ;{ }^{13} \mathrm{C}$ NMR $\left(126 \mathrm{MHz}, \mathrm{DMSO}-d_{6}\right) \delta 178,8,142,7,139,4$, $137,6,135,9,129,2,129,0,128,7,128,6,128,6,128,0,127,4,127,3,126,1,124,9,121,6,109,5$, 78,6, 71,0, 59,4, 38,6, 31,8; HRMS (ESI) 444,2081 [M+H] ${ }^{+}$(kalkulált: 444,2076).

( \pm )-(2R,3'R,5S,6S)-terc-Butil-5-metil-2'-oxo-2-fenil-1,3-diazaspiro[biciklo[3.1.0]hexán4,3'-indolin]-6-karboxilát (( \pm$)-313 a)$

${ }^{1} \mathrm{H}$ NMR $\left(500 \mathrm{MHz}, \mathrm{DMSO}-d_{6}\right) \delta 10,56(\mathrm{~s}, 1 \mathrm{H}), 7,50(\mathrm{~d}, J=7,2 \mathrm{~Hz}, 2 \mathrm{H}), 7,45-7,37(\mathrm{~m}, 3 \mathrm{H})$, $7,34(\mathrm{t}, J=7,5 \mathrm{~Hz}, 1 \mathrm{H}), 7,27(\mathrm{t}, J=7,7 \mathrm{~Hz}, 1 \mathrm{H}), 7,00(\mathrm{t}, J=7,5 \mathrm{~Hz}, 1 \mathrm{H}), 6,88(\mathrm{~d}, J=7,7 \mathrm{~Hz}$, 1H), 5,78 (d, $J=7,7 \mathrm{~Hz}, 1 \mathrm{H}), 4,19(\mathrm{~d}, J=7,8 \mathrm{~Hz}, 1 \mathrm{H}), 3,18(\mathrm{~s}, 1 \mathrm{H}), 1,37$ (s, 9H), 1,09 (s, 3H); ${ }^{13} \mathrm{C}$ NMR $(126 \mathrm{MHz}$, DMSO-d $) \delta 178,9,168,5,143,4,138,9,130,0,128,7,128,2,127,3,126,9$, $125,1,122,2,110,2,79,2,71,4,55,8,36,2,28,2,10,6$; HRMS (ESI) 392,1976 [M+H] ${ }^{+}$ (kalkulált: 392,1974).

$( \pm)-(2 R, 3 ' R, 5 S)-2,5-D i f e n i l-1,3-d i a z a s p i r o[b i c i k l o[3.1 .0] h e x a ́ n-4,3 '-i n d o l i n]-2 '-o n \quad(( \pm)-$ 314a)

${ }^{1} \mathrm{H}$ NMR $\left(500 \mathrm{MHz}, \mathrm{DMSO}-d_{6}\right) \delta 10,21(\mathrm{~s}, 1 \mathrm{H}), 7,66(\mathrm{~d}, J=7,6 \mathrm{~Hz}, 1 \mathrm{H}), 7,62(\mathrm{~d}, J=7,6 \mathrm{~Hz}$, 2H), 7,42 (t, $J=7,5 \mathrm{~Hz}, 2 \mathrm{H}), 7,36(\mathrm{t}, J=7,0 \mathrm{~Hz}, 1 \mathrm{H}), 7,30(\mathrm{t}, J=7,7 \mathrm{~Hz}, 1 \mathrm{H}), 7,20-7,13(\mathrm{~m}$, $3 \mathrm{H}), 7,06(\mathrm{t}, J=7,6 \mathrm{~Hz}, 1 \mathrm{H}), 7,03-6,99(\mathrm{~m}, 2 \mathrm{H}), 6,79(\mathrm{~d}, J=7,8 \mathrm{~Hz}, 1 \mathrm{H}), 6,02(\mathrm{~d}, J=7,6$ $\mathrm{Hz}, 1 \mathrm{H}), 4,21(\mathrm{~d}, J=7,7 \mathrm{~Hz}, 1 \mathrm{H}), 2,89(\mathrm{~s}, 1 \mathrm{H}), 1,53(\mathrm{~s}, 1 \mathrm{H}) ;{ }^{13} \mathrm{C}$ NMR $\left(126 \mathrm{MHz}, \mathrm{DMSO}-d_{6}\right)$ $\delta 178,8,143,3,139,3,137,9,130,0,128,6,128,4,128,3,128,2,127,7,127,6,127,6,125,3$, 122,2, 110,0, 78,34, 70,5, 55,8, 29,8; HRMS (ESI) 354,1606 [M+H] $]^{+}$(kalkulált: 354,1606). 
( \pm )-(2R,3'R,5S,6R)-5-(4-Klórfenil)-6'-metoxi-2,6-difenil-1,3-diazaspiro[biciklo[3.1.0] hexán-4,3'-indolin]-2'-on (( \pm )-315a)

${ }^{1} \mathrm{H}$ NMR $\left(500 \mathrm{MHz}, \mathrm{DMSO}-d_{6}\right) \delta 10,13(\mathrm{~s}, 1 \mathrm{H}), 7,87(\mathrm{~d}, J=8,3 \mathrm{~Hz}, 1 \mathrm{H}), 7,60(\mathrm{~d}, J=7,5 \mathrm{~Hz}$, $2 \mathrm{H}), 7,37(\mathrm{t}, J=7,5 \mathrm{~Hz}, 2 \mathrm{H}), 7,31(\mathrm{t}, J=7,3 \mathrm{~Hz}, 1 \mathrm{H}), 7,17-7,06(\mathrm{~m}, 6 \mathrm{H}), 7,03(\mathrm{t}, J=7,1 \mathrm{~Hz}$, $1 \mathrm{H}), 6,84(\mathrm{~s}, 1 \mathrm{H}), 6,67(\mathrm{~d}, J=7,7 \mathrm{~Hz}, 1 \mathrm{H}), 6,31(\mathrm{~d}, J=2,4 \mathrm{~Hz}, 1 \mathrm{H}), 6,18(\mathrm{~d}, J=8,3 \mathrm{~Hz}, 1 \mathrm{H})$, $4,37(\mathrm{~d}, J=8,4 \mathrm{~Hz}, 1 \mathrm{H}), 4,18(\mathrm{~s}, 1 \mathrm{H}), 3,78(\mathrm{~s}, 3 \mathrm{H}) ;{ }^{13} \mathrm{C}$ NMR $\left(126 \mathrm{MHz}, \mathrm{DMSO}-d_{6}\right) \delta 178,8$, $161,1,144,6,139,2,136,6,132,9,132,2,128,7,128,2,127,9,127,8,127,3,127,0,126,2,119,0$, 107,2, 96,9, 79,8, 72,1, 62,9, 55,7; HRMS (ESI) 494,1642 és 496,1600 [M+H] ${ }^{+}$(kalkulált: 494,1635 és 496,1635).

( \pm )-(2R,3'R,5S,6R)-5'-Klór-5-(4-Klórfenil)-2,6-difenil-1,3-diazaspiro[biciklo[3.1.0]hexán4,3'-indolin]-2'-on $(( \pm)-316 a)$

${ }^{1} \mathrm{H}$ NMR $\left(500 \mathrm{MHz}, \mathrm{DMSO}-d_{6}\right) \delta 10,32(\mathrm{~s}, 1 \mathrm{H}), 8,10(\mathrm{~s}, 1 \mathrm{H}), 7,62(\mathrm{~d}, J=7,5 \mathrm{~Hz}, 2 \mathrm{H}), 7,44-$ $7,29(\mathrm{~m}, 4 \mathrm{H}), 7,23-6,95(\mathrm{~m}, 8 \mathrm{H}), 6,78(\mathrm{~d}, J=8,2 \mathrm{~Hz}, 1 \mathrm{H}), 6,20(\mathrm{~d}, J=7,9 \mathrm{~Hz}, 1 \mathrm{H}), 4,54(\mathrm{~d}$, $J=8,0 \mathrm{~Hz}, 1 \mathrm{H}), 4,27(\mathrm{~s}, 1 \mathrm{H}) ;{ }^{13} \mathrm{C}$ NMR $\left(126 \mathrm{MHz}, \mathrm{DMSO}-d_{6}\right) \delta 178,1,142,2,138,9,136,4$, $132,4,130,1,129,6,128,7,128,3,128,2,128,1,127,8,127,4,127,1,126,5,125,6,111,6,80,1$, 72,5, 63,3, 23,3; HRMS (ESI) 498,1147, 500,1113 és 502,1066 [M+H] ${ }^{+}$(kalkulált: 498,1140, 500,1140 és 502,1140).

( \pm )-(2R,3'R,5S,6S)-Etil-5-metil-2'-oxo-2-(p-tolil)-1,3-diazaspiro[biciklo[3.1.0]hexán-4,3' indolin]-6-karboxilát $(( \pm)-317 a)$

${ }^{1} \mathrm{H}$ NMR $\left(500 \mathrm{MHz}, \mathrm{DMSO}-d_{6}\right) \delta 10,56(\mathrm{~s}, 1 \mathrm{H}), 7,46(\mathrm{~d}, J=7,5 \mathrm{~Hz}, 1 \mathrm{H}), 7,39$ (d, $J=7,7 \mathrm{~Hz}$, $2 \mathrm{H}), 7,27(\mathrm{t}, J=7,7 \mathrm{~Hz}, 1 \mathrm{H}), 7,20(\mathrm{~d}, J=7,8 \mathrm{~Hz}, 2 \mathrm{H}), 7,02(\mathrm{t}, J=7,6 \mathrm{~Hz}, 1 \mathrm{H}), 6,87(\mathrm{~d}, J=$ $7,7 \mathrm{~Hz}, 1 \mathrm{H}), 5,78(\mathrm{~d}, J=7,3 \mathrm{~Hz}, 1 \mathrm{H}), 4,16(\mathrm{~d}, J=7,4 \mathrm{~Hz}, 1 \mathrm{H}), 4,12-4,02(\mathrm{~m}, 2 \mathrm{H}), 3,29$ (s, $1 \mathrm{H}), 2,31(\mathrm{~s}, 3 \mathrm{H}), 1,14(\mathrm{t}, J=7,1 \mathrm{~Hz}, 3 \mathrm{H}), 1,09(\mathrm{~s}, 3 \mathrm{H}) ;{ }^{13} \mathrm{C}$ NMR $\left(126 \mathrm{MHz}, \mathrm{DMSO}-d_{6}\right) \delta$ $179,0,169,3,143,3,137,5,135,8,130,0,129,3,127,3,127,0,125,1,122,3,110,2,79,0,71,3$, 60,9, 56,4, 35,2, 21,2, 14,6, 10,6; HRMS (ESI) 378,1812 [M+H] ${ }^{+}$(kalkulált: 378,1818).

$( \pm)-(2 R, 3 ' R, 5 S, 6 S)$-Etil-2-(4-klórfenil)-5-metil-2'-oxo-1,3-diazaspiro[biciklo[3.1.0]hexán4,3'-indolin]-6-karboxilát (( \pm -318a)

${ }^{1} \mathrm{H}$ NMR (500 MHz, DMSO- $\left.d_{6}\right) \delta 10,59(\mathrm{~s}, 1 \mathrm{H}), 7,53(\mathrm{~d}, J=8,2 \mathrm{~Hz}, 2 \mathrm{H}), 7,49-7,41(\mathrm{~m}, 3 \mathrm{H})$, $7,28(\mathrm{t}, J=7,7 \mathrm{~Hz}, 1 \mathrm{H}), 7,03(\mathrm{t}, J=7,6 \mathrm{~Hz}, 1 \mathrm{H}), 6,88(\mathrm{~d}, J=7,8 \mathrm{~Hz}, 1 \mathrm{H}), 5,79(\mathrm{~d}, J=7,2 \mathrm{~Hz}$, $1 \mathrm{H}), 4,29(\mathrm{~d}, J=7,3 \mathrm{~Hz}, 1 \mathrm{H}), 4,16-4,01(\mathrm{~m}, 2 \mathrm{H}), 3,32(\mathrm{~d}, J=27,4 \mathrm{~Hz}, 1 \mathrm{H}), 1,15(\mathrm{t}, J=7,0$ $\mathrm{Hz}, 3 \mathrm{H}), 1,09$ (s, 3H); ${ }^{13} \mathrm{C}$ NMR (126 MHz, DMSO-d $) \delta 179,0,169,1,143,3,137,7,132,9$, 130,1, 129,3, 128,7, 126,9, 125,1, 122,3, 110,3, 78,4, 71,3, 61,0, 56,5, 35,3, 14,6, 10,6; HRMS (ESI) 398,1267 és 400,1234 [M+H] ${ }^{+}$(kalkulált: 398,1271 és 400,1271).

$( \pm)-(2 R, 3 ' R, 5 S, 6 S)$-Etil-2-(4-fluorfenil)-5-metil-2'-oxo-1,3-diazaspiro[biciklo[3.1.0]hexán4,3'-indolin]-6-karboxilát $(( \pm)-319 a)$

${ }^{1} \mathrm{H}$ NMR $\left(500 \mathrm{MHz}, \mathrm{DMSO}-d_{6}\right) \delta 10,58(\mathrm{~s}, 1 \mathrm{H}), 7,55(\mathrm{dd}, J=8,5,5,6 \mathrm{~Hz}, 2 \mathrm{H}), 7,46(\mathrm{~d}, J=7,5$ $\mathrm{Hz}, 1 \mathrm{H}), 7,31-7,19(\mathrm{~m}, 3 \mathrm{H}), 7,03(\mathrm{t}, J=7,6 \mathrm{~Hz}, 1 \mathrm{H}), 6,88(\mathrm{~d}, J=7,7 \mathrm{~Hz}, 1 \mathrm{H}), 5,80(\mathrm{~d}, J=$ 7,1 Hz, 1H), 4,26 (d, $J=7,3 \mathrm{~Hz}, 1 \mathrm{H}), 4,15-3,99$ (m, 2H), 3,31 (s, 1H), 1,14 (t, $J=7,1 \mathrm{~Hz}$, $3 \mathrm{H}), 1,09$ (s, 3H); ${ }^{13} \mathrm{C}$ NMR (126 MHz, DMSO- $\left.d_{6}\right) \delta 179,0,169,2,162,3(\mathrm{~d}, J=243,5 \mathrm{~Hz})$, $143,32,135,0(\mathrm{~d}, J=2,7 \mathrm{~Hz}), 130,1,129,38(\mathrm{~d}, J=8,2 \mathrm{~Hz}), 126,9,125,1,122,3,115,5(\mathrm{~d}, J=$ 21,2 Hz), 110,2, 78,4, 71,3, 61,0, 56,5, 35,3, 14,6, 10,6; HRMS (ESI) 382,1559 [M+H] ${ }^{+}$ (kalkulált: 382,1567). 
( \pm )-(2R,3' $R, 5 S, 6 S)$-Etil-2-benzil-5-metil-2'-oxo-1,3-diazaspiro[biciklo[3.1.0]hexán-4,3'indolin]-6-karboxilát $(( \pm)-320 a)$

${ }^{1} \mathrm{H}$ NMR $\left(500 \mathrm{MHz}, \mathrm{DMSO}-d_{6}\right) \delta 10,48(\mathrm{~s}, 1 \mathrm{H}), 7,48(\mathrm{~d}, J=7,4 \mathrm{~Hz}, 1 \mathrm{H}), 7,34-7,24(\mathrm{~m}, 5 \mathrm{H})$, $7,25-7,17(\mathrm{~m}, 1 \mathrm{H}), 7,05(\mathrm{t}, J=7,5 \mathrm{~Hz}, 1 \mathrm{H}), 6,84(\mathrm{~d}, J=7,7 \mathrm{~Hz}, 1 \mathrm{H}), 4,79-4,67(\mathrm{~m}, 1 \mathrm{H})$, 4,25 - 4,05 (m, 2H), 3,71 (d, $J=9,4 \mathrm{~Hz}, 1 \mathrm{H}), 2,95-2,75(\mathrm{~m}, 2 \mathrm{H}), 1,22(\mathrm{t}, J=7,1 \mathrm{~Hz}, 3 \mathrm{H})$, $1,01(\mathrm{~s}, 3 \mathrm{H}) ;{ }^{13} \mathrm{C}$ NMR $\left(126 \mathrm{MHz}\right.$, DMSO- $\left.d_{6}\right) \delta 178,4,169,4,143,4,138,9,130,1,129,7,128,6$, $126,7,126,6,124,9,122,1,110,2,80,8,71,9,60,9,56,1,37,5,34,4,14,7,10,5$; HRMS (ESI) $378,1812[\mathrm{M}+\mathrm{H}]^{+}$(kalkulált: 378,1818).

( \pm )-(2R,3'R,5S,6S)-Etil-2-(4-hidroxibenzil)-5-metil-2'-oxo-1,3-diazaspiro[biciklo[3.1.0] hexán-4,3'-indolin]-6-karboxilát (( \pm -321a)

${ }^{1} \mathrm{H}$ NMR $\left(500 \mathrm{MHz}, \mathrm{DMSO}-d_{6}\right) \delta 10,47(\mathrm{~s}, 1 \mathrm{H}), 9,17(\mathrm{~s}, 1 \mathrm{H}), 7,46(\mathrm{~d}, J=7,5 \mathrm{~Hz}, 1 \mathrm{H}), 7,27(\mathrm{t}$, $J=7,6 \mathrm{~Hz}, 1 \mathrm{H}), 7,12-7,00(\mathrm{~m}, 3 \mathrm{H}), 6,84(\mathrm{~d}, J=7,8 \mathrm{~Hz}, 1 \mathrm{H}), 6,66(\mathrm{~d}, J=7,9 \mathrm{~Hz}, 2 \mathrm{H}), 4,71$ $-4,63(\mathrm{~m}, 1 \mathrm{H}), 4,22-4,04(\mathrm{~m}, 2 \mathrm{H}), 3,63$ (d, $J=9,4 \mathrm{~Hz}, 1 \mathrm{H}), 3,30(\mathrm{~s}, 1 \mathrm{H}), 2,81-2,63(\mathrm{~m}, 2 \mathrm{H})$, $1,22(\mathrm{t}, J=7,1 \mathrm{~Hz}, 3 \mathrm{H}), 1,00(\mathrm{~s}, 3 \mathrm{H}) ;{ }^{13} \mathrm{C}$ NMR $\left(126 \mathrm{MHz}, \mathrm{DMSO}-d_{6}\right) \delta 178,5,169,5,156,1$, 143,4, 130,5, 130,0, 129,0, 126,7, 124,9, 122,1, 115,3, 110,1, 81,1, 71,8, 60,9, 56,1, 36,7, 34,3, 14,7, 10,5; HRMS (ESI) 394,1767 [M+H] ${ }^{+}$(kalkulált: 394,1767).

$( \pm)-(2 R, 3 ' R, 5 S, 6 S)$-Etil-5-metil-2'-oxo-2-fenetil-1,3-diazaspiro[biciklo[3.1.0]hexán-4,3'indolin]-6-karboxilát $(( \pm)-322 a)$

${ }^{1} \mathrm{H}$ NMR $\left(500 \mathrm{MHz}, \mathrm{CDCl}_{3}\right) \delta 8,12(\mathrm{~s}, 1 \mathrm{H}), 7,38(\mathrm{~d}, J=7,5 \mathrm{~Hz}, 1 \mathrm{H}), 7,33-7,27(\mathrm{~m}, 3 \mathrm{H}), 7,23$ $-7,17(\mathrm{~m}, 3 \mathrm{H}), 7,10(\mathrm{t}, J=7,6 \mathrm{~Hz}, 1 \mathrm{H}), 6,90(\mathrm{~d}, J=7,8 \mathrm{~Hz}, 1 \mathrm{H}), 5,07(\mathrm{t}, J=6,4 \mathrm{~Hz}, 1 \mathrm{H}), 4,32$ $-4,12(\mathrm{~m}, 2 \mathrm{H}), 3,14(\mathrm{~s}, 1 \mathrm{H}), 2,97-2,74(\mathrm{~m}, 2 \mathrm{H}), 2,17(\mathrm{~s}, 1 \mathrm{H}), 2,08-1,97(\mathrm{~m}, 1 \mathrm{H}), 1,92-1,80$ $(\mathrm{m}, 1 \mathrm{H}), 1,32-1,27(\mathrm{~m}, 6 \mathrm{H}) ;{ }^{13} \mathrm{C}$ NMR $\left(126 \mathrm{MHz}, \mathrm{CDCl}_{3}\right) \delta 179,1,169,1,141,7,141,6,130,0$, $128,5,128,2,126,5,123,9,123,2,110,4,78,5,71,2,61,4,56,4,35,0,34,3,32,7,14,4,10,3$; HRMS (ESI) 392,1977 [M+H] $]^{+}$(kalkulált: 392,1974).

( \pm )-(2R,3' $R, 5 S, 6 S)$-Etil-2-((benziltio)-metil)-5-metil-2'-oxo-1,3-diazaspiro[biciklo[3.1.0] hexán-4,3'-indolin]-6-karboxilát $(( \pm)-323 a)$

${ }^{1} \mathrm{H}$ NMR $\left(500 \mathrm{MHz}, \mathrm{DMSO}-d_{6}\right) \delta 10,52(\mathrm{~s}, 1 \mathrm{H}), 7,39(\mathrm{~d}, J=7,5 \mathrm{~Hz}, 1 \mathrm{H}), 7,37-7,29(\mathrm{~m}, 4 \mathrm{H})$, $7,26(\mathrm{~d}, J=7,6 \mathrm{~Hz}, 2 \mathrm{H}), 7,03(\mathrm{t}, J=7,6 \mathrm{~Hz}, 1 \mathrm{H}), 6,85(\mathrm{~d}, J=7,8 \mathrm{~Hz}, 1 \mathrm{H}), 4,87-4,69(\mathrm{~m}, 1 \mathrm{H})$, $4,22-3,98(\mathrm{~m}, 2 \mathrm{H}), 3,86(\mathrm{q}, J=13,6 \mathrm{~Hz}, 2 \mathrm{H}), 3,82-3,71(\mathrm{~m}, 1 \mathrm{H}), 3,26(\mathrm{~s}, 1 \mathrm{H}), 2,66-2,56$ $(\mathrm{m}, 1 \mathrm{H}), 1,17(\mathrm{t}, J=7,1 \mathrm{~Hz}, 3 \mathrm{H}), 1,03(\mathrm{~s}, 3 \mathrm{H}) ;{ }^{13} \mathrm{C}$ NMR $\left(126 \mathrm{MHz}, \mathrm{DMSO}-d_{6}\right) \delta 178,5,169,2$, $143,4,139,1,130,1,129,3,128,9,127,3,126,6,124,8,122,2,110,3,80,4,71,4,61,0,56,7,36,3$, 34,5, 31,6, 14,7, 10,5; HRMS (ESI) 424,1701 [M+H] ${ }^{+}$(kalkulált: 424,1695).

$( \pm)-(2 R, 3 ' R, 5 S, 6 S)$-Etil-2-((1H-indol-3-il)-metil)-5-metil-2'-oxo-1,3-diazaspiro[biciklo [3.1.0]hexán-4,3'-indolin]-6-karboxilát (( \pm$)-324 a)$

${ }^{1} \mathrm{H}$ NMR $\left(500 \mathrm{MHz}\right.$, DMSO- $\left.d_{6}\right) \delta 10,83$ (s, 1H), 10,46 (s, 1H), 7,54 (d, $\left.J=7,9 \mathrm{~Hz}, 1 \mathrm{H}\right), 7,48$ $(\mathrm{d}, J=7,6 \mathrm{~Hz}, 1 \mathrm{H}), 7,34(\mathrm{~d}, J=8,1 \mathrm{~Hz}, 1 \mathrm{H}), 7,27(\mathrm{t}, J=7,7 \mathrm{~Hz}, 1 \mathrm{H}), 7,22-7,18(\mathrm{~m}, 1 \mathrm{H}), 7,06$ $(\mathrm{q}, J=7,4 \mathrm{~Hz}, 2 \mathrm{H}), 6,96(\mathrm{t}, J=7,5 \mathrm{~Hz}, 1 \mathrm{H}), 6,84(\mathrm{~d}, J=7,8 \mathrm{~Hz}, 1 \mathrm{H}), 4,84(\mathrm{q}, J=6,9 \mathrm{~Hz}, 1 \mathrm{H})$, 4,27 - 4,00 (m, 2H), 3,67 (d, $J=9,3 \mathrm{~Hz}, 1 \mathrm{H}), 3,37(\mathrm{~s}, 1 \mathrm{H}), 2,95(\mathrm{qd}, J=14,7,6,5 \mathrm{~Hz}, 2 \mathrm{H})$, $1,22(\mathrm{t}, J=7,1 \mathrm{~Hz}, 3 \mathrm{H}), 1,01(\mathrm{~s}, 3 \mathrm{H}) ;{ }^{13} \mathrm{C}$ NMR (126 MHz, DMSO-d $\left.{ }\right) \delta 178,5,169,5,143,4$, $136,5,130,0,127,9,126,9,124,8,123,9,122,1,121,2,118,8,118,6,111,7,111,3,110,1,80,4$, 71,9, 60,9, 56,3, 34,3, 27,2, 14,7, 10,5; HRMS (ESI) 417,1930 [M+H] ${ }^{+}$(kalkulált: 417,1927).

$( \pm)-(2 R, 3 ' R, 5 S, 6 S)$-Etil-2-(hidroximetil)-5-metil-2'-oxo-1,3-diazaspiro[biciklo[3.1.0] hexán-4,3'-indolin]-6-karboxilát (( \pm$)$-325a)

${ }^{1} \mathrm{H}$ NMR $\left(500 \mathrm{MHz}, \mathrm{CDCl}_{3}\right) \delta 8,49(\mathrm{~s}, 1 \mathrm{H}), 7,38(\mathrm{~d}, J=7,5 \mathrm{~Hz}, 1 \mathrm{H}), 7,31-7,25(\mathrm{~m}, 1 \mathrm{H}), 7,07$ (t, $J=7,6 \mathrm{~Hz}, 1 \mathrm{H}), 6,90(\mathrm{~d}, J=7,8 \mathrm{~Hz}, 1 \mathrm{H}), 5,04(\mathrm{t}, J=4,4 \mathrm{~Hz}, 1 \mathrm{H}), 4,30-4,09(\mathrm{~m}, 2 \mathrm{H}), 3,95$ 
- 3,79 (m, 2H), 3,53 - 3,44 (m, 1H), 3,46 (s, 1H), 1,28 (t, J=7,1 Hz, 3H), 1,22 (s, 3H); ${ }^{13} \mathrm{C}$ NMR $\left(126 \mathrm{MHz}, \mathrm{CDCl}_{3}\right) \delta 178,9,169,1,141,7,130,0,126,3,124,0,123,1,110,5,78,2,70,8$, 62,0, 61,5, 55,5, 35,9, 14,3, 10,1; HRMS (ESI) 318,1455 [M+H] $]^{+}$(kalkulált: 318,1454).

$( \pm)-(2 R, 3 ' R, 5 S, 6 S)$-Etil-2-(3-amino-3-oxopropil)-5-metil-2'-oxo-1,3-diazaspiro[biciklo [3.1.0]hexán-4,3'-indolin]-6-karboxilát (( \pm$)$-326a)

${ }^{1} \mathrm{H}$ NMR $\left(500 \mathrm{MHz}, \mathrm{DMSO}-d_{6}\right) \delta 10,48(\mathrm{~s}, 1 \mathrm{H}), 7,43(\mathrm{~d}, J=7,4 \mathrm{~Hz}, 1 \mathrm{H}), 7,30(\mathrm{~s}, 1 \mathrm{H}), 7,26(\mathrm{t}$, $J=7,8 \mathrm{~Hz}, 1 \mathrm{H}), 7,02(\mathrm{t}, J=7,5 \mathrm{~Hz}, 1 \mathrm{H}), 6,84(\mathrm{~d}, J=7,8 \mathrm{~Hz}, 1 \mathrm{H}), 6,74(\mathrm{~s}, 1 \mathrm{H}), 4,60-4,47(\mathrm{~m}$, $1 \mathrm{H}), 4,20-4,01(\mathrm{~m}, 2 \mathrm{H}), 3,61(\mathrm{~d}, J=9,5 \mathrm{~Hz}, 1 \mathrm{H}), 3,14(\mathrm{~s}, 1 \mathrm{H}), 2,20(\mathrm{t}, J=7,7 \mathrm{~Hz}, 2 \mathrm{H}), 1,73$ $(\mathrm{p}, J=7,2,6,7 \mathrm{~Hz}, 2 \mathrm{H}), 1,19(\mathrm{t}, J=7,1 \mathrm{~Hz}, 3 \mathrm{H}), 1,01(\mathrm{~s}, 3 \mathrm{H}) ;{ }^{13} \mathrm{C}$ NMR $(126 \mathrm{MHz}, \mathrm{DMSO}-$ d6) $\delta 178,5,174,2,169,4,143,4,130,0,126,8,124,9,122,1,110,1,79,3,71,9,60,9,56,1,34,1$, 32,5, 26,9, 14,7, 10,5; HRMS (ESI) 359,1722 [M+H] ${ }^{+}$(kalkulált: 359,1719).

( \pm )-(2R,3'R,5S,6S)-Etil-2-butil-5-metil-2'-oxo-1,3-diazaspiro[biciklo[3.1.0]hexán-4,3'indolin]-6-karboxilát $(( \pm)-327 a)$

${ }^{1} \mathrm{H}$ NMR $\left(500 \mathrm{MHz}, \mathrm{CDCl}_{3}\right) \delta 8,42(\mathrm{~s}, 1 \mathrm{H}), 7,37(\mathrm{~d}, J=7,5 \mathrm{~Hz}, 1 \mathrm{H}), 7,29(\mathrm{t}, J=7,9 \mathrm{~Hz}, 1 \mathrm{H})$, $7,09(\mathrm{t}, J=7,6 \mathrm{~Hz}, 1 \mathrm{H}), 6,91(\mathrm{~d}, J=7,8 \mathrm{~Hz}, 1 \mathrm{H}), 4,97(\mathrm{t}, J=6,0 \mathrm{~Hz}, 1 \mathrm{H}), 4,44-3,99(\mathrm{~m}, 2 \mathrm{H})$, $3,07(\mathrm{~s}, 1 \mathrm{H}), 2,15(\mathrm{~s}, 1 \mathrm{H}), 1,76-1,65(\mathrm{~m}, 2 \mathrm{H}), 1,53$ (tdt, $J=13,0,9,4,4,2 \mathrm{~Hz}, 2 \mathrm{H}), 1,38$ (q, $J$ $=7,1 \mathrm{~Hz}, 2 \mathrm{H}), 1,29(\mathrm{t}, J=7,3 \mathrm{~Hz}, 3 \mathrm{H}), 1,26(\mathrm{~s}, 3 \mathrm{H}), 0,91(\mathrm{t}, J=7,2 \mathrm{~Hz}, 3 \mathrm{H}) ;{ }^{13} \mathrm{C}$ NMR $(126$ $\left.\mathrm{MHz}, \mathrm{CDCl}_{3}\right) \delta 179,1,169,2,141,7,130,0,126,6,123,8,123,1,110,4,79,0,71,2,61,3,56,4$, 34,9, 32,2, 28,6, 22,8, 14,3, 14,0, 10,3; HRMS (ESI) 344,1974 [M+H] (kalkulált: 344,1974).

$( \pm)-(1 R, 2 \mathrm{a} S, 3 ' S, 7 \mathrm{a} R)$-Etil-7a-metil-2'-oxo-1,2a,3,4,5,7a-hexahidrospiro[azirino[1,2c]pirrolo[1,2-a]imidazol-7,3'-indolin]-1-karboxilát (( \pm -328a)

${ }^{1} \mathrm{H}$ NMR $\left(500 \mathrm{MHz}, \mathrm{DMSO}-d_{6}\right) \delta 10,51(\mathrm{~s}, 1 \mathrm{H}), 7,49(\mathrm{~d}, J=7,5 \mathrm{~Hz}, 1 \mathrm{H}), 7,31(\mathrm{t}, J=7,7 \mathrm{~Hz}$, $1 \mathrm{H}), 7,05(\mathrm{t}, J=7,6 \mathrm{~Hz}, 1 \mathrm{H}), 6,89(\mathrm{~d}, J=7,7 \mathrm{~Hz}, 1 \mathrm{H}), 5,03$ (t, $J=6,4 \mathrm{~Hz}, 1 \mathrm{H}), 4,17-4,06$ (m, $2 \mathrm{H}), 3,26-3,15(\mathrm{~m}, 1 \mathrm{H}), 2,80(\mathrm{~s}, 1 \mathrm{H}), 2,37(\mathrm{t}, J=7,5 \mathrm{~Hz}, 1 \mathrm{H}), 2,19-2,08(\mathrm{~m}, 1 \mathrm{H}), 2,02-$ $1,92(\mathrm{~m}, 1 \mathrm{H}), 1,78-1,68(\mathrm{~m}, 1 \mathrm{H}), 1,68-1,57(\mathrm{~m}, 1 \mathrm{H}), 1,19(\mathrm{t}, J=7,1 \mathrm{~Hz}, 3 \mathrm{H}), 1,01(\mathrm{~s}, 3 \mathrm{H})$; ${ }^{13} \mathrm{C}$ NMR $\left(126 \mathrm{MHz}\right.$, DMSO- $\left.d_{6}\right) \delta 178,1,168,5,144,1,130,4,126,6,124,2,122,0,110,6,86,6$, $72,8,61,0,60,7,50,2,38,1,28,2,26,8,14,7,11,6$; HRMS (ESI) 328,1660 [M+H] ${ }^{+}$(kalkulált: $328,1661)$.

( \pm )-(1R,2a $S, 3 ' S, 7 \mathrm{a} R)$-Etil-5'-klór-7a-metil-2'-oxo-1,2a,3,4,5,7a-hexahidrospiro[azirino [1,2-c]pirrolo[1,2-a]imidazol-7,3'-indolin]-1-karboxilát (( \pm -329a)

${ }^{1} \mathrm{H}$ NMR $\left(500 \mathrm{MHz}, \mathrm{CDCl}_{3}\right) \delta 8,70(\mathrm{~s}, 1 \mathrm{H}), 7,44(\mathrm{~d}, J=2,1 \mathrm{~Hz}, 1 \mathrm{H}), 7,32(\mathrm{dd}, J=8,3,2,1 \mathrm{~Hz}$, $1 \mathrm{H}), 6,90(\mathrm{~d}, J=8,3 \mathrm{~Hz}, 1 \mathrm{H}), 5,36(\mathrm{t}, J=6,5 \mathrm{~Hz}, 1 \mathrm{H}), 4,33-4,16(\mathrm{~m}, 2 \mathrm{H}), 3,19-3,08(\mathrm{~m}$, 1H), 2,73-2,59 (m, 2H), 2,36-2,25 (m, 1H), 2,11-2,01 (m, 1H), 2,00-1,84 (m, 1H), 1,82 $-1,70(\mathrm{~m}, 1 \mathrm{H}), 1,31(\mathrm{t}, J=7,1 \mathrm{~Hz}, 3 \mathrm{H}), 1,27(\mathrm{~s}, 3 \mathrm{H}) ;{ }^{13} \mathrm{C} \mathrm{NMR}\left(126 \mathrm{MHz}, \mathrm{CDCl}_{3}\right) \delta 178,5$, $168,3,141,1,130,2,127,8,126,7,125,7,111,6,87,1,73,3,61,5,61,3,50,4,38,3,28,2,26,7$,

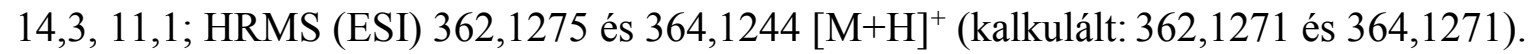

( \pm )-(1R,2aS,3' $S, 7 \mathrm{a} R)$-Etil-6'-metoxi-7a-metil-2'-oxo-1,2a,3,4,5,7a-hexahidrospiro[azirino [1,2-c]pirrolo[1,2-a]imidazol-7,3'-indolin]-1-karboxilát (( \pm -330a)

${ }^{1} \mathrm{H}$ NMR $\left(500 \mathrm{MHz}, \mathrm{CDCl}_{3}\right) \delta 8,69(\mathrm{~s}, 1 \mathrm{H}), 7,36(\mathrm{~d}, J=8,4 \mathrm{~Hz}, 1 \mathrm{H}), 6,60(\mathrm{dd}, J=8,4,2,3 \mathrm{~Hz}$, $1 \mathrm{H}), 6,53(\mathrm{~d}, J=2,3 \mathrm{~Hz}, 1 \mathrm{H}), 5,34(\mathrm{t}, J=6,5 \mathrm{~Hz}, 1 \mathrm{H}), 4,34-4,22(\mathrm{~m}, 1 \mathrm{H}), 4,21-4,10(\mathrm{~m}$, $1 \mathrm{H}), 3,84(\mathrm{~s}, 3 \mathrm{H}), 3,23-3,10(\mathrm{~m}, 1 \mathrm{H}), 2,68-2,62(\mathrm{~m}, 2 \mathrm{H}), 2,36-2,21(\mathrm{~m}, 1 \mathrm{H}), 2,09-1,96$ $(\mathrm{m}, 1 \mathrm{H}), 1,99-1,85(\mathrm{~m}, 1 \mathrm{H}), 1,83-1,71(\mathrm{~m}, 1 \mathrm{H}), 1,29(\mathrm{t}, J=7,1 \mathrm{~Hz}, 3 \mathrm{H}), 1,26(\mathrm{~s}, 3 \mathrm{H}) ;{ }^{13} \mathrm{C}$ NMR $\left(126 \mathrm{MHz}, \mathrm{CDCl}_{3}\right) \delta 179,5,168,7,161,4,143,9,127,1,115,5,107,3,97,6,86,9,73,1$, $61,4,61,2,55,6,50,6,38,4,28,4,26,6,14,4,11,1$; HRMS (ESI) 358,1768 [M+H] ${ }^{+}$(kalkulált: $358,1767)$. 
$( \pm)-(1 R, 2 \mathrm{a} S, 3 ' S, 7 \mathrm{a} R)$-Etil-1',7a-dimetil-2'-oxo-1,2a,3,4,5,7a-hexahidrospiro[azirino[1,2c]pirrolo[1,2-a]imidazol-7,3'-indolin]-1-karboxilát (( \pm$)-331 a)$

${ }^{1} \mathrm{H}$ NMR $\left(500 \mathrm{MHz}, \mathrm{CDCl}_{3}\right) \delta 7,49(\mathrm{~d}, J=7,5 \mathrm{~Hz}, 1 \mathrm{H}), 7,40(\mathrm{t}, J=7,8 \mathrm{~Hz}, 1 \mathrm{H}), 7,12(\mathrm{t}, J=$ $7,6 \mathrm{~Hz}, 1 \mathrm{H}), 6,87(\mathrm{~d}, J=7,8 \mathrm{~Hz}, 1 \mathrm{H}), 5,39$ (t, $J=6,5 \mathrm{~Hz}, 1 \mathrm{H}), 4,31-4,24(\mathrm{~m}, 1 \mathrm{H}), 4,21-4,15$ $(\mathrm{m}, 1 \mathrm{H}), 3,21(\mathrm{~s}, 3 \mathrm{H}), 3,20-3,12(\mathrm{~m}, 1 \mathrm{H}), 2,72(\mathrm{~s}, 1 \mathrm{H}), 2,60(\mathrm{t}, J=7,7 \mathrm{~Hz}, 1 \mathrm{H}), 2,34-2,23$ $(\mathrm{m}, 1 \mathrm{H}), 2,07-1,98(\mathrm{~m}, 1 \mathrm{H}), 1,96-1,86(\mathrm{~m}, 1 \mathrm{H}), 1,81-1,75(\mathrm{~m}, 1 \mathrm{H}), 1,29(\mathrm{t}, J=7,2 \mathrm{~Hz}$, $3 \mathrm{H}), 1,19$ (s, 3H); ${ }^{13} \mathrm{C}$ NMR $\left(126 \mathrm{MHz}, \mathrm{CDCl}_{3}\right) \delta 176,6,168,7,145,4,130,1,126,0,123,5$, 122,4, 108,6, 86,9, 72,8, 61,4, 61,3, 50,6, 38,4, 28,2, 26,6, 26,1, 14,4, 11,1; HRMS (ESI) $342,1819[\mathrm{M}+\mathrm{H}]^{+}$(kalkulált: 342,1818).

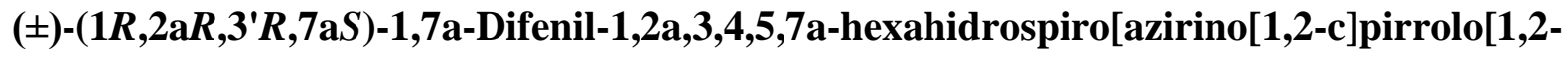
a]imidazol-7,3'-indolin]-2'-on (( \pm )-332a)

${ }^{1} \mathrm{H}$ NMR $\left(500 \mathrm{MHz}, \mathrm{CDCl}_{3}\right) \delta 7,78(\mathrm{~d}, J=7,5 \mathrm{~Hz}, 1 \mathrm{H}), 7,70(\mathrm{~s}, 1 \mathrm{H}), 7,40-7,32(\mathrm{~m}, 1 \mathrm{H}), 7,18$ (t, $J=7,6 \mathrm{~Hz}, 1 \mathrm{H}), 7,13-6,99(\mathrm{~m}, 5 \mathrm{H}), 7,00-6,88(\mathrm{~m}, 4 \mathrm{H}), 6,80(\mathrm{~d}, J=7,7 \mathrm{~Hz}, 1 \mathrm{H}), 5,70(\mathrm{t}$, $J=6,4 \mathrm{~Hz}, 1 \mathrm{H}), 3,55-3,46(\mathrm{~m}, 1 \mathrm{H}), 3,45(\mathrm{~s}, 1 \mathrm{H}), 2,81(\mathrm{t}, J=7,6 \mathrm{~Hz}, 1 \mathrm{H}), 2,45-2,35(\mathrm{~m}$, $1 \mathrm{H}), 2,16-2,08(\mathrm{~m}, 1 \mathrm{H}), 2,08-1,97(\mathrm{~m}, 1 \mathrm{H}), 1,98-1,86(\mathrm{~m}, 1 \mathrm{H}) ;{ }^{13} \mathrm{C}$ NMR $(126 \mathrm{MHz}$, $\left.\mathrm{CDCl}_{3}\right) \delta 178,4,142,6,135,9,132,9,130,0,127,7,127,6,127,5,127,3,126,7,126,2,125,4$, 122,2 , 110,6, 87,3, 74,0, 69,0, 51,1, 42,9, 28,6, 27,0; HRMS (ESI) 394,1924 [M+H] ${ }^{+}$(kalkulált: 394,1919).

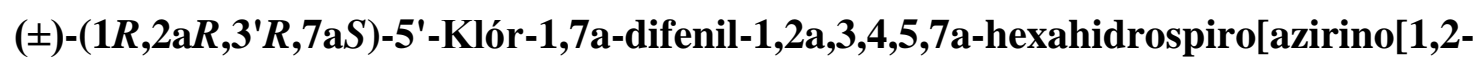
c]pirrolo[1,2-a]imidazol-7,3'-indolin]-2'-on (( \pm -333a)

${ }^{1} \mathrm{H}$ NMR $\left(500 \mathrm{MHz}, \mathrm{CDCl}_{3}\right) \delta 8,00(\mathrm{~s}, 1 \mathrm{H}), 7,20-7,10(\mathrm{~m}, 4 \mathrm{H}), 7,09-6,98(\mathrm{~m}, 4 \mathrm{H}), 6,96-$ $6,83(\mathrm{~m}, 4 \mathrm{H}), 6,53(\mathrm{~d}, J=8,2 \mathrm{~Hz}, 1 \mathrm{H}), 5,53(\mathrm{t}, J=6,3 \mathrm{~Hz}, 1 \mathrm{H}), 3,95(\mathrm{~s}, 1 \mathrm{H}), 3,94-3,88(\mathrm{~m}$, $1 \mathrm{H}), 2,90(\mathrm{t}, J=7,8 \mathrm{~Hz}, 1 \mathrm{H}), 2,43-2,31(\mathrm{~m}, 1 \mathrm{H}), 2,21-2,11(\mathrm{~m}, 1 \mathrm{H}), 2,05-1,94(\mathrm{~m}, 1 \mathrm{H})$, $1,95-1,83(\mathrm{~m}, 1 \mathrm{H}) ;{ }^{13} \mathrm{C}$ NMR $\left(126 \mathrm{MHz}, \mathrm{CDCl}_{3}\right) \delta 175,1,137,2,136,0,135,2,133,4,128,2$, $128,1,127,7,127,6,127,5,127,1,126,5,125,3,110,3,88,6,72,2,70,4,49,2,42,7,28,8,27,3$; HRMS (ESI) 428,1523 és 430,1489 [M+H] $]^{+}$(kalkulált: 428,1530 és 430,1500).

\section{Etil-1,5-dimetil-2-fenil-1H-imidazol-4-karboxilát (336)}

${ }^{1} \mathrm{H}$ NMR $\left(500 \mathrm{MHz}, \mathrm{DMSO}-d_{6}\right) \delta$ 7,64 (d, $\left.J=7,1 \mathrm{~Hz}, 2 \mathrm{H}\right), 7,57-7,46(\mathrm{~m}, 3 \mathrm{H}), 4,24(\mathrm{q}, J=$ $7,1 \mathrm{~Hz}, 2 \mathrm{H}), 3,60$ (s, 3H), 2,54 (s, 3H), 1,29 (t, $J=7,1 \mathrm{~Hz}, 3 \mathrm{H}),{ }^{13} \mathrm{C}$ NMR (126 MHz, DMSO$\left.d_{6}\right) \delta 163,8,146,9,138,1,130,6,129,4,129,2,129,0,128,0,59,7,32,5,14,9,10,7$; HRMS (ESI) 245,1284 [M+H] $]^{+}$(kalkulált: 245,1285).

\section{Etil-2-(4-metoxifenil)-1,5-dimetil-1H-imidazol-4-karboxilát (337)}

${ }^{1} \mathrm{H}$ NMR (500 MHz, Kloroform- $d$ ) $\delta 7,52(\mathrm{~d}, J=8,8 \mathrm{~Hz}, 2 \mathrm{H}), 6,97(\mathrm{~d}, J=8,8 \mathrm{~Hz}, 2 \mathrm{H}), 4,39$ (q, $J=7,1 \mathrm{~Hz}, 2 \mathrm{H}), 3,85(\mathrm{~s}, 3 \mathrm{H}), 3,56(\mathrm{~s}, 3 \mathrm{H}), 2,61(\mathrm{~s}, 3 \mathrm{H}), 1,40(\mathrm{t}, J=7,1 \mathrm{~Hz}, 3 \mathrm{H}),{ }^{13} \mathrm{C}$ NMR $(126$ MHz, Kloroform- $d$ ) $\delta 164,2,160,2$, 147,4, 137,0, 130,7, 128,4, 122,6, 113,9, 60,2, 55,4, 31,9, 14,6, 10,6; HRMS (ESI) 275,1390 [M+H] $]^{+}$(kalkulált: 275,1391).

\section{Etil-2-(4-fluorfenil)-1,5-dimetil-1 $H$-imidazol-4-karboxilát (338)}

${ }^{1} \mathrm{H}$ NMR (500 MHz, Kloroform- $d$ ) $\delta$ 7,60 - 7,54 (m, 2H), 7,15 (t, $\left.J=8,7 \mathrm{~Hz}, 2 \mathrm{H}\right), 4,40$ (q, $J=$ 7,1 Hz, 2H), 3,57 (s, 3H), 2,61 (s, 3H), 1,40 (t, $J=7,1 \mathrm{~Hz}, 3 \mathrm{H}),{ }^{13} \mathrm{C}$ NMR (126 MHz, Kloroformd) $\delta 164,2,163,1(\mathrm{~d}, J=223,5 \mathrm{~Hz}), 146,5,137,2,131,2(\mathrm{~d}, J=8,3 \mathrm{~Hz}), 128,6,126,3,115,7(\mathrm{~d}$,

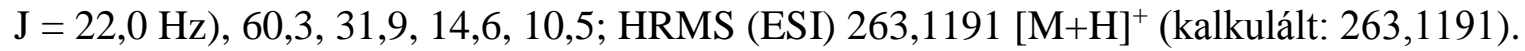

\section{Etil-1,5-dimetil-2-(4-nitrofenil)-1H-imidazol-4-karboxilát (339)}

${ }^{1} \mathrm{H}$ NMR (500 MHz, Kloroform- $d$ ) $\delta 8,31(\mathrm{~d}, J=8,8 \mathrm{~Hz}, 2 \mathrm{H}), 7,83$ (d, $\left.J=8,8 \mathrm{~Hz}, 2 \mathrm{H}\right), 4,41$ (q, $J=7,1 \mathrm{~Hz}, 2 \mathrm{H}), 3,66(\mathrm{~s}, 3 \mathrm{H}), 2,64(\mathrm{~s}, 3 \mathrm{H}), 1,41(\mathrm{t}, J=7,1 \mathrm{~Hz}, 3 \mathrm{H}),{ }^{13} \mathrm{C} \mathrm{NMR}(126 \mathrm{MHz}$, 
Kloroform- $d$ ) $\delta 163,7,147,9,145,0,138,3,136,2,129,9,129,6,123,8,60,6,32,3,14,54,10,6$; HRMS (ESI) 290,1138 [M+H] ${ }^{+}$(kalkulált: 290,1136).

\section{Etil-1,5-dimetil-2-(piridin-2-il)-1H-imidazol-4-karboxilát (340)}

${ }^{1} \mathrm{H}$ NMR $(500 \mathrm{MHz}$, Kloroform- $d$ ) $\delta 8,61-8,56(\mathrm{~m}, 1 \mathrm{H}), 8,23(\mathrm{~d}, J=8,0 \mathrm{~Hz}, 1 \mathrm{H}), 7,77(\mathrm{dt}, J$ $=7,8,1,8 \mathrm{~Hz}, 1 \mathrm{H}), 7,26-7,22(\mathrm{~m}, 1 \mathrm{H}), 4,41(\mathrm{q}, J=7,1 \mathrm{~Hz}, 2 \mathrm{H}), 4,04(\mathrm{~s}, 3 \mathrm{H}), 2,62(\mathrm{~s}, 3 \mathrm{H})$, $1,42(\mathrm{t}, J=7,1 \mathrm{~Hz}, 3 \mathrm{H}),{ }^{13} \mathrm{C}$ NMR $(126 \mathrm{MHz}$, Kloroform- $d$ ) $\delta 164,0,150,2,148,1,144,7,138,8$, 136,7, 128,6, 124,0, 123,0, 77,3, 60,4, 33,0, 14,6, 10,4; HRMS (ESI) 246,1237 [M+H] ${ }^{+}$ (kalkulált: 246,1238).

\section{Etil-1,5-dimetil-2-(piridin-3-il)-1H-imidazol-4-karboxilát (341)}

${ }^{1} \mathrm{H}$ NMR (500 MHz, Kloroform- $d$ ) $\delta 8,84(\mathrm{~s}, 1 \mathrm{H}), 8,68(\mathrm{~d}, J=4,8 \mathrm{~Hz}, 1 \mathrm{H}), 7,98(\mathrm{~d}, J=7,8 \mathrm{~Hz}$, 1H), 7,41 (dd, $J=7,8,4,8 \mathrm{~Hz}, 1 \mathrm{H}), 4,41$ (q, $J=7,1 \mathrm{~Hz}, 2 \mathrm{H}), 3,63$ (s, 3H), 2,64 (s, 3H), 1,41 (t, $J=7,1 \mathrm{~Hz}, 3 \mathrm{H}),{ }^{13} \mathrm{C}$ NMR $(126 \mathrm{MHz}$, Kloroform- $d$ ) $\delta 163,8,150,1,149,6,144,4,137,7,136,9$, 129,4, 126,5, 123,5, 60,5, 32,0, 14,6, 10,6; HRMS (ESI) 246,1235 [M+H] ${ }^{+}$(kalkulált: 246,1238).

\section{Etil-1,5-dimetil-2-(5-metilfurán-2-il)-1H-imidazol-4-karboxilát (342)}

${ }^{1} \mathrm{H}$ NMR (500 MHz, Kloroform- $d$ ) $\delta 6,79(\mathrm{~d}, J=3,2 \mathrm{~Hz}, 1 \mathrm{H}), 6,15-6,04(\mathrm{~m}, 1 \mathrm{H}), 4,38$ (q, $J=$ $7,1 \mathrm{~Hz}, 2 \mathrm{H}), 3,73(\mathrm{~s}, 3 \mathrm{H}), 2,59(\mathrm{~s}, 3 \mathrm{H}), 2,37(\mathrm{~s}, 3 \mathrm{H}), 1,40(\mathrm{t}, J=7,1 \mathrm{~Hz}, 3 \mathrm{H}),{ }^{13} \mathrm{C}$ NMR $(126$ MHz, Kloroform-d) $\delta 164,0,153,1,143,1,139,4,136,9,128,6,111,7,107,6,60,3,31,8,14,5$, 13,8, 10,2; HRMS (ESI) 249,1233 [M+H] (kalkulált: 249,1234).

\section{Etil-1,2,5-trimetil-1H-imidazol-4-karboxilát (343)}

${ }^{1} \mathrm{H}$ NMR (500 MHz, Kloroform- $d$ ) $\delta$ 4,35 (q, $\left.J=7,2 \mathrm{~Hz}, 2 \mathrm{H}\right), 3,45$ (s, 3H), 2,51 (s, 3H), 2,39 (s, 3H), 1,38 (t, $J=7,1 \mathrm{~Hz}, 3 \mathrm{H}),{ }^{13} \mathrm{C}$ NMR (126 MHz, Kloroform- $d$ ) $\delta 164,0,144,4,136,2$, 127,1, 60,1, 30,3, 14,6, 13,5, 10,3; HRMS (ESI) 183,1130 [M+H] ${ }^{+}$(kalkulált: 183,1129).

\section{Etil-2-izopropil-1,5-dimetil-1H-imidazol-4-karboxilát (344)}

${ }^{1} \mathrm{H}$ NMR $(500 \mathrm{MHz}$, Kloroform- $d$ ) $\delta 4,36$ (q, $J=7,1 \mathrm{~Hz}, 2 \mathrm{H}), 3,48$ (s, 3H), 3,02 (hept, $J=6,9$ $\mathrm{Hz}, 1 \mathrm{H}), 2,51$ (s, 3H), 1,46 - 1,27 (m, 9H) ${ }^{13} \mathrm{C}$ NMR (126 MHz, Kloroform-d) $\delta$ 164,2, 152,6, 136,1, 127,2, 60,2, 30,0, 26,6, 20,9, 14,6, 10,4; HRMS (ESI) 211,1438 [M+H] ${ }^{+}$(kalkulált: 211,1442).

\section{Etil-2-(terc-butil)-1,5-dimetil-1H-imidazol-4-karboxilát (345)}

${ }^{1} \mathrm{H}$ NMR (500 MHz, Kloroform- $d$ ) $\delta 4,34$ (q, $\left.J=7,1 \mathrm{~Hz}, 2 \mathrm{H}\right), 3,62$ (s, 3H), 2,50 (s, 3H), 1,45 $(\mathrm{s}, 9 \mathrm{H}), 1,38(\mathrm{t}, J=7,1 \mathrm{~Hz}, 3 \mathrm{H}),{ }^{13} \mathrm{C}$ NMR $(126 \mathrm{MHz}$, Kloroform- $d$ ) $\delta 164,3,154,0,137,6$, 126,3, 60,2, 33,3, 32,5, 29,1, 14,5, 10,5; HRMS (ESI) 225,1594 [M+H] ${ }^{+}$(kalkulált: 225,1598).

\section{Etil-2-heptil-1,5-dimetil-1H-imidazol-4-karboxilát (346)}

${ }^{1} \mathrm{H}$ NMR (500 MHz, Kloroform- $d$ ) $\delta 4,36$ (q, $\left.J=7,1 \mathrm{~Hz}, 2 \mathrm{H}\right), 3,46$ (s, 3H), 2,76 - 2,64 (m, 2H), $2,51(\mathrm{~s}, 3 \mathrm{H}), 1,76-1,63(\mathrm{~m}, 3 \mathrm{H}), 1,38(\mathrm{t}, J=7,1 \mathrm{~Hz}, 3 \mathrm{H}), 1,36-1,23(\mathrm{~m}, 7 \mathrm{H}), 0,88(\mathrm{t}, J=6,7$ $\mathrm{Hz}, 3 \mathrm{H}),{ }^{13} \mathrm{C}$ NMR (126 MHz, Kloroform- $d$ ) $\delta 164,2,148,4,136,1,127,3,60,1,31,7,30,3$, 29,5, 29,0, 28,1, 27,6, 22,6, 14,6, 14,1, 10,3; HRMS (ESI) 267,2069 [M+H] ${ }^{+}$(kalkulált: 267,2068).

\section{Etil-2-ciklopropil-1,5-dimetil-1H-imidazol-4-karboxilát (347)}

${ }^{1} \mathrm{H}$ NMR (500 MHz, Kloroform- $d$ ) $\delta$ 4,34 (q, $\left.J=7,1 \mathrm{~Hz}, 2 \mathrm{H}\right), 3,58$ (s, 3H), 2,51 (s, 3H), 1,78 $1,70(\mathrm{~m}, 1 \mathrm{H}), 1,37(\mathrm{t}, J=7,1 \mathrm{~Hz}, 3 \mathrm{H}), 1,08-1,00(\mathrm{~m}, 2 \mathrm{H}), 0,98-0,90(\mathrm{~m}, 2 \mathrm{H}),{ }^{13} \mathrm{C} \mathrm{NMR}(126$ MHz, Kloroform- $d$ ) $\delta 164,1,148,9,136,3,126,9,60,1,30,0,14,5,10,3,7,5,6,3$; HRMS (ESI) 209,1281 [M+H] $]^{+}$(kalkulált: 209,1285). 


\section{Etil-2-ciklohexil-1,5-dimetil-1H-imidazol-4-karboxilát (348)}

${ }^{1} \mathrm{H}$ NMR (500 MHz, Kloroform- $d$ ) $\delta 4,36$ (q, $\left.J=7,1 \mathrm{~Hz}, 2 \mathrm{H}\right), 3,47$ (s, 3H), 2,63 (tt, $J=12,1$, $3,4 \mathrm{~Hz}, 1 \mathrm{H}), 2,51(\mathrm{~s}, 3 \mathrm{H}), 1,92-1,83(\mathrm{~m}, 4 \mathrm{H}), 1,81-1,68(\mathrm{~m}, 3 \mathrm{H}), 1,38(\mathrm{t}, J=7,1 \mathrm{~Hz}, 3 \mathrm{H})$, $1,34-1,29(\mathrm{~m}, 3 \mathrm{H}),{ }^{13} \mathrm{C}$ NMR (126 MHz, Kloroform- $d$ ) $\delta 164,2,151,9,135,8,127,4,60,1$, 36,4, 31,0, 30,0, 26,3, 25,6, 14,6, 10,3; HRMS (ESI) 251, $1756[\mathrm{M}+\mathrm{H}]^{+}$(kalkulált: 251,1755).

\section{Etil-1,2-diizopropil-5-metil-1H-imidazol-4-karboxilát (349)}

${ }^{1} \mathrm{H}$ NMR (500 MHz, Kloroform- $d$ ) $\delta$ 4,53 (hept, $J=7,1 \mathrm{~Hz}, 1 \mathrm{H}$ ), 4,35 (q, $J=7,1 \mathrm{~Hz}, 2 \mathrm{H}$ ), 3,06 (hept, $J=6,9 \mathrm{~Hz}, 1 \mathrm{H}), 2,62(\mathrm{~s}, 3 \mathrm{H}), 1,52(\mathrm{~d}, J=7,1 \mathrm{~Hz}, 6 \mathrm{H}), 1,38(\mathrm{t}, J=7,1 \mathrm{~Hz}, 3 \mathrm{H}), 1,36(\mathrm{~d}$, $J=6,8 \mathrm{~Hz}, 6 \mathrm{H}),{ }^{13} \mathrm{C}$ NMR $(126 \mathrm{MHz}$, Kloroform- $d$ ) $\delta 164,4,60,1,47,2,27,2,21,8,14,6$; HRMS (ESI) 239,1754 [M+H] ${ }^{+}$(kalkulált: 239,1755).

\section{Etil-1-benzil-5-metil-2-fenil-1H-imidazol-4-karboxilát (350)}

${ }^{1} \mathrm{H}$ NMR (500 MHz, Kloroform- $d$ ) $\delta 7,51(\mathrm{~d}, J=6,7 \mathrm{~Hz}, 2 \mathrm{H}), 7,41-7,29(\mathrm{~m}, 6 \mathrm{H}), 6,97(\mathrm{~d}, J=$ $7,3 \mathrm{~Hz}, 2 \mathrm{H}), 5,19$ (s, 2H), 4,42 (q, $J=7,1 \mathrm{~Hz}, 2 \mathrm{H}), 2,47(\mathrm{~s}, 3 \mathrm{H}), 1,42(\mathrm{t}, J=7,1 \mathrm{~Hz}, 3 \mathrm{H}),{ }^{13} \mathrm{C}$ NMR (126 MHz, Kloroform-d) $\delta 164,1,148,1,137,1,136,0,130,0,129,4,129,2,128,5,127,9$, 125,6, 60,4, 48,1, 14,6, 10,5; HRMS (ESI) 321,1596 [M+H] ${ }^{+}$(kalkulált: 321,1598).

\section{Etil-1-benzil-2-izopropil-5-metil-1H-imidazol-4-karboxilát (351)}

${ }^{1} \mathrm{H}$ NMR (500 MHz, Kloroform- $d$ ) $\delta$ 7,34-7,27 (m, 3H), 6,90 (d, $\left.J=6,8 \mathrm{~Hz}, 2 \mathrm{H}\right), 5,10(\mathrm{~s}, 2 \mathrm{H})$, $4,38(\mathrm{q}, J=7,1 \mathrm{~Hz}, 2 \mathrm{H}), 2,92$ (hept, $J=6,9 \mathrm{~Hz}, 1 \mathrm{H}), 2,42$ (s, 3H), 1,40 (t, $J=7,1 \mathrm{~Hz}, 3 \mathrm{H}), 1,29$ $(\mathrm{d}, J=6,9 \mathrm{~Hz}, 6 \mathrm{H}),{ }^{13} \mathrm{C}$ NMR $(126 \mathrm{MHz}$, Kloroform- $d) \delta 164,2,153,3,135,9,135,7,129,1$, 127,9, 125,5, 60,3, 46,5, 26,6, 21,6, 14,6, 10,3; HRMS (ESI) 287,1755 [M+H] ${ }^{+}$(kalkulált: 287,1755).

\section{Etil-1-ciklohexil-5-metil-2-fenil-1H-imidazol-4-karboxilát (352)}

${ }^{1} \mathrm{H}$ NMR (500 MHz, Kloroform- $d$ ) $\delta$ 7,48-7,40 (m, 5H), 4,38 (q, $\left.J=7,1 \mathrm{~Hz}, 2 \mathrm{H}\right), 4,08$ (tt, $J=$ $12,1,4,0 \mathrm{~Hz}, 1 \mathrm{H}), 2,75(\mathrm{~s}, 3 \mathrm{H}), 1,98-1,80(\mathrm{~m}, 6 \mathrm{H}), 1,70-1,63(\mathrm{~m}, 1 \mathrm{H}), 1,39(\mathrm{t}, J=7,1 \mathrm{~Hz}, 3 \mathrm{H})$, 1,24-1,10 (m, 3H), ${ }^{13} \mathrm{C}$ NMR (126 MHz, Kloroform- $d$ ) $\delta$ 164,3, 147,8, 136,3, 131,4, 129,9, 129,2, 128,3, 60,2, 57,8, 32,0, 26,1, 25,1, 14,6, 12,1; HRMS (ESI) 313,1911 [M+H] ${ }^{+}$(kalkulált: $313,1911)$.

\section{Etil-1-(4-fluorfenil)-5-metil-2-fenil-1H-imidazol-4-karboxilát (353)}

${ }^{1} \mathrm{H}$ NMR $(500 \mathrm{MHz}$, Kloroform- $d$ ) $\delta 7,35(\mathrm{~d}, J=7,2 \mathrm{~Hz}, 2 \mathrm{H}), 7,27-7,18(\mathrm{~m}, 3 \mathrm{H}), 7,17$ (d, $J=$ $6,4 \mathrm{~Hz}, 4 \mathrm{H}), 4,44(\mathrm{q}, J=7,1 \mathrm{~Hz}, 2 \mathrm{H}), 2,41(\mathrm{~s}, 3 \mathrm{H}), 1,43(\mathrm{t}, J=7,1 \mathrm{~Hz}, 3 \mathrm{H}),{ }^{13} \mathrm{C}$ NMR $(126$ MHz, Kloroform- $d$ ) $\delta 164,0,162,6$ (d, $J=250,8 \mathrm{~Hz}), 146,9,138,1,132,4,129,8,129,7,129,5$, $129,2,128,8,128,2,116,96(\mathrm{~d}, J=23,0 \mathrm{~Hz}), 77,3,60,5,14,6,11,1$; HRMS (ESI) 325,1344 $[\mathrm{M}+\mathrm{H}]^{+}$(kalkulált: 325,1347).

\section{terc-Butil-1,5-dimetil-2-fenil-1 $H$-imidazol-4-karboxilát (354)}

${ }^{1} \mathrm{H}$ NMR (500 MHz, Kloroform- $d$ ) $\delta$ 7,62 - 7,52 (m, 2H), 7,47 - 7,38 (m, 3H), 3,57 (s, 3H), $2,58(\mathrm{~s}, 3 \mathrm{H}), 1,60(\mathrm{~s}, 9 \mathrm{H}),{ }^{13} \mathrm{C}$ NMR $(126 \mathrm{MHz}$, Kloroform- $d$ ) $\delta 163,4,147,3,136,1,130,3$,

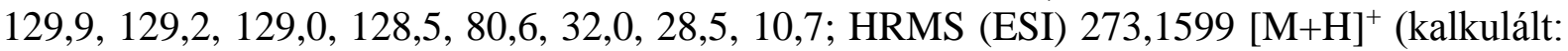
273,1598).

\section{1-Metil-2,4,5-trifenil-1H-imidazol (355)}

${ }^{1} \mathrm{H}$ NMR (500 MHz, Kloroform- $\left.d\right) \delta 7,75(\mathrm{~d}, J=7,5 \mathrm{~Hz}, 2 \mathrm{H}), 7,55(\mathrm{~d}, J=7,7 \mathrm{~Hz}, 2 \mathrm{H}), 7,52-$ $7,39(\mathrm{~m}, 8 \mathrm{H}), 7,21(\mathrm{t}, J=7,5 \mathrm{~Hz}, 2 \mathrm{H}), 7,14(\mathrm{t}, J=7,3 \mathrm{~Hz}, 1 \mathrm{H}), 3,51(\mathrm{~s}, 3 \mathrm{H}),{ }^{13} \mathrm{C}$ NMR $(126$ MHz, Kloroform- $d$ ) $\delta 147,9,137,7,134,6,131,2,131,0,130,9,130,5,129,1,129,1,128,8$, 128,6, 128,1, 127,0, 126,3, 33,2; HRMS (ESI) 311,1542 [M+H] $]^{+}$(kalkulált: 311,1543). 


\section{5-(4-Metoxifenil)-1-metil-2,4-difenil-1H-imidazol (356)}

${ }^{1} \mathrm{H}$ NMR (500 MHz, Kloroform- $d$ ) $\delta 7,74(\mathrm{~d}, J=7,5 \mathrm{~Hz}, 2 \mathrm{H}), 7,57$ (d, $\left.J=7,6 \mathrm{~Hz}, 2 \mathrm{H}\right), 7,49$ (t, $J=7,5 \mathrm{~Hz}, 2 \mathrm{H}), 7,42(\mathrm{t}, J=7,4 \mathrm{~Hz}, 1 \mathrm{H}), 7,33(\mathrm{~d}, J=8,2 \mathrm{~Hz}, 2 \mathrm{H}), 7,22(\mathrm{t}, J=7,6 \mathrm{~Hz}, 2 \mathrm{H}), 7,14$ $(\mathrm{t}, J=7,3 \mathrm{~Hz}, 1 \mathrm{H}), 7,01(\mathrm{~d}, J=8,2 \mathrm{~Hz}, 2 \mathrm{H}), 3,88(\mathrm{~s}, 3 \mathrm{H}), 3,49(\mathrm{~s}, 3 \mathrm{H}),{ }^{13} \mathrm{C}$ NMR $(126 \mathrm{MHz}$, Kloroform-d) $\delta 159,8,147,6,137,5,134,8,132,2,131,1,130,3,129,1,128,7,128,6,128,1$, 126,8, 126,2, 123,3, 114,5, 55,3, 33,1; HRMS (ESI) 341,1648 [M+H] $]^{+}$(kalkulált: 341,1649).

\section{5-(4-Fluorfenil)-1-metil-2,4-difenil-1H-imidazol (357)}

${ }^{1} \mathrm{H}$ NMR $\left(500 \mathrm{MHz}\right.$, DMSO- $\left.d_{6}\right) \delta 7,79(\mathrm{~d}, J=7,5 \mathrm{~Hz}, 2 \mathrm{H}), 7,59-7,48(\mathrm{~m}, 5 \mathrm{H}), 7,44(\mathrm{~d}, J=$ $7,7 \mathrm{~Hz}, 2 \mathrm{H}), 7,39(\mathrm{t}, J=8,6 \mathrm{~Hz}, 2 \mathrm{H}), 7,25(\mathrm{t}, J=7,6 \mathrm{~Hz}, 2 \mathrm{H}), 7,16(\mathrm{t}, J=7,4 \mathrm{~Hz}, 1 \mathrm{H}), 3,48(\mathrm{~s}$, $3 \mathrm{H}), 3,35(\mathrm{~s}, 3 \mathrm{H}),{ }^{13} \mathrm{C}$ NMR (126 MHz, DMSO-d6) $\delta 162,7(\mathrm{~d}, J=246,1 \mathrm{~Hz}), 147,4,137,1$, $135,1,133,5$ (d, $J=8,3 \mathrm{~Hz}), 131,1,129,9,129,2,129,0,128,6,127,6,126,7,116,6$ (d, $J=21,3$ Hz), 33,5; HRMS (ESI) 329,1447 [M+H] $]^{+}$(kalkulált: 329,1449).

\section{5-(4-Klórfenil)-1-metil-2,4-difenil-1H-imidazol (358)}

${ }^{1} \mathrm{H}$ NMR (500 MHz, Kloroform- $d$ ) $\delta 7,73$ (d, $\left.J=7,4 \mathrm{~Hz}, 2 \mathrm{H}\right), 7,55-7,47$ (m, 4H), 7,47 - 7,41 (m, 3H), 7,36 (d, $J=8,0 \mathrm{~Hz}, 2 \mathrm{H}), 7,24(\mathrm{t}, J=7,5 \mathrm{~Hz}, 2 \mathrm{H}), 7,17(\mathrm{t}, J=7,3 \mathrm{~Hz}, 1 \mathrm{H}), 3,51(\mathrm{~s}, 3 \mathrm{H})$, ${ }^{13} \mathrm{C}$ NMR (126 MHz, Kloroform-d) $\delta$ 148,3, 138,2, 134,7, 134,4, 132,2, 130,8, 129,7, 129,4, 129,1, 128,9, 128,6, 128,2, 127,1, 126,6, 33,2; HRMS (ESI) 345,1155 és 347,1126 [M+H] ${ }^{+}$ (kalkulált: 345,1154 és 347,1124).

\section{5-Benzil-1-metil-2,4-difenil-1H-imidazol (359)}

${ }^{1} \mathrm{H}$ NMR (500 MHz, Kloroform- $d$ ) $\delta$ 7,71 - 7,64 (m, 4H), 7,46 (t, $\left.J=7,3 \mathrm{~Hz}, 2 \mathrm{H}\right), 7,41(\mathrm{t}, J=$ $7,4 \mathrm{~Hz}, 1 \mathrm{H}), 7,35$ (q, $J=7,8 \mathrm{~Hz}, 4 \mathrm{H}), 7,29-7,22(\mathrm{~m}, 2 \mathrm{H}), 7,21(\mathrm{~d}, J=7,5 \mathrm{~Hz}, 2 \mathrm{H}), 4,28(\mathrm{~s}$, 2H), 3,46 (s, 3H), ${ }^{13} \mathrm{C}$ NMR (126 MHz, Kloroform-d) $\delta 147,7,139,4,138,3,135,0,130,9$, $129,1,128,9,128,7,128,5,128,5,127,9,127,3,126,7,126,7,32,1,30,5$; HRMS (ESI) 325,1698 $[\mathrm{M}+\mathrm{H}]^{+}$(kalkulált: 325,1700).

\section{terc-Butil 2-izopropil-1,5-dimetil-1H-imidazol-4-karboxilát (361)}

${ }^{1} \mathrm{H}$ NMR (500 MHz, Kloroform- $d$ ) $\delta 3,45$ (s, 3H), 2,98 (hept, $\left.J=6,9 \mathrm{~Hz}, 1 \mathrm{H}\right), 2,44$ (s, 3H), 1,58 $(\mathrm{s}, 9 \mathrm{H}), 1,34(\mathrm{~d}, J=6,9 \mathrm{~Hz}, 6 \mathrm{H}),{ }^{13} \mathrm{C}$ NMR $(126 \mathrm{MHz}$, Kloroform- $d$ ) $\delta 163,3,152,4,134,3$, 128,6, 80,1 , 30,0, 28,4, 26,6, 20,9, 10,5; HRMS (ESI) 239,1753 [M+H] ${ }^{+}$(kalkulált: 239, 1755).

\section{2-Izopropil-1-metil-4,5-difenil-1H-imidazol (362)}

${ }^{1} \mathrm{H}$ NMR (500 MHz, Kloroform- $d$ ) $\delta$ 7,48 - 7,36 (m, 5H), 7,32 (d, $\left.J=6,1 \mathrm{~Hz}, 2 \mathrm{H}\right), 7,17(\mathrm{t}, J=$ 7,6 Hz, 2H), 7,09 (t, $J=7,4 \mathrm{~Hz}, 1 \mathrm{H}), 3,39$ (s, 3H), 3,09 (hept, $J=6,9 \mathrm{~Hz}, 1 \mathrm{H}), 1,44$ (d, $J=6,8$ $\mathrm{Hz}, 6 \mathrm{H}),{ }^{13} \mathrm{C}$ NMR (126 MHz, Kloroform-d) $\delta$ 152,8, 136,2, 135,1, 131,5, 130,9, 128,9, 128,6, 128,2, 128,0, 126,9, 125,9, 30,7, 26,7, 21,4; HRMS (ESI) 277,1701 [M+H] ${ }^{+}$(kalkulált: 277,1700).

\section{2-Izopropil-5-(4-metoxifenil)-1-metil-4-fenil-1H-imidazol (363)}

${ }^{1} \mathrm{H}$ NMR (500 MHz, Kloroform- $d$ ) $\delta 7,47(\mathrm{~d}, J=7,2 \mathrm{~Hz}, 2 \mathrm{H}), 7,24(\mathrm{~d}, J=8,7 \mathrm{~Hz}, 2 \mathrm{H}), 7,18(\mathrm{t}$, $J=7,6 \mathrm{~Hz}, 2 \mathrm{H}), 7,09(\mathrm{t}, J=7,3 \mathrm{~Hz}, 1 \mathrm{H}), 6,96(\mathrm{~d}, J=8,7 \mathrm{~Hz}, 2 \mathrm{H}), 3,86(\mathrm{~s}, 3 \mathrm{H}), 3,37(\mathrm{~s}, 3 \mathrm{H})$, $3,08(\mathrm{p}, J=6,9 \mathrm{~Hz}, 1 \mathrm{H}), 1,43(\mathrm{~d}, J=6,9 \mathrm{~Hz}, 6 \mathrm{H}),{ }^{13} \mathrm{C}$ NMR $(126 \mathrm{MHz}$, Kloroform- $d) \delta 159,6$, $152,5,136,0,135,2,132,2,128,3,128,0,126,8,125,8,123,7,114,4,55,3,30,6,26,7,21,4$; HRMS (ESI) 307,1806 [M+H] $]^{+}$(kalkulált: 307,1805).

\section{5-(4-Fluorfenil)-2-izopropil-1-metil-4-fenil-1 $H$-imidazol (364)}

${ }^{1} \mathrm{H}$ NMR (500 MHz, Kloroform- $d$ ) $\delta 7,43(\mathrm{~d}, J=7,0 \mathrm{~Hz}, 2 \mathrm{H}), 7,34-7,27$ (m, 2H), 7,19 (t, $J=$ 7,6 Hz, 3H), 7,16-7,09 (m, 2H), 3,38 (s, 3H), 3,09 (p, $J=6,9 \mathrm{~Hz}, 1 \mathrm{H}), 1,43(\mathrm{~d}, J=6,9 \mathrm{~Hz}$, $6 \mathrm{H}),{ }^{13} \mathrm{C}$ NMR (126 MHz, Kloroform- $d$ ) $\delta$ 162,70 (d, $\left.J=248,1 \mathrm{~Hz}\right), 152,9,136,5,134,9,132,8$ 
(d, $J=8,2 \mathrm{~Hz}), 128,1,127,5(\mathrm{~d}, J=3,1 \mathrm{~Hz}), 127,4,126,9,126,0,116,1$ (d, $J=21,8 \mathrm{~Hz}), 30,7$, 26,7, 21,4; HRMS (ESI) 295,1606 [M+H] $]^{+}$(kalkulált: 295,1606).

\section{5-(4-Klórfenil)-2-izopropil-1-metil-4-fenil-1H-imidazol (365)}

${ }^{1} \mathrm{H}$ NMR (500 MHz, Kloroform- $d$ ) $\delta 7,47-7,38(\mathrm{~m}, 4 \mathrm{H}), 7,26(\mathrm{~d}, J=3,9 \mathrm{~Hz}, 2 \mathrm{H}), 7,20(\mathrm{t}, J=$ 7,5 Hz, 2H), 7,12 (t, $J=7,3 \mathrm{~Hz}, 1 \mathrm{H}), 3,39$ (s, 3H), 3,08 (p, $J=6,9 \mathrm{~Hz}, 1 \mathrm{H}), 1,43$ (d, $J=6,8 \mathrm{~Hz}$, $6 \mathrm{H}),{ }^{13} \mathrm{C}$ NMR (126 MHz, Kloroform-d) $\delta$ 153,2, 136,8, 134,8, 134,3, 132,2, 129,9, 129,2, 128,2, 127,2, 127,0, 126,2, 30,8, 26,7, 21,4; HRMS (ESI) 311,1311 és 313,1283 [M+H] ${ }^{+}$ (kalkulált: 311,1310 és 313,1281).

\section{5-Benzil-2-izopropil-1-metil-4-fenil-1H-imidazol (366)}

${ }^{1} \mathrm{H}$ NMR (500 MHz, Kloroform- $d$ ) $\delta 7,60$ (d, $\left.J=7,3 \mathrm{~Hz}, 2 \mathrm{H}\right), 7,35-7,28$ (m, 4H), 7,25 - 7,17 (m, 2H), 7,14 (d, J= 7,4 Hz, 2H), 4,16 (s, 2H), 3,32 (s, 3H), 3,03 (p, J = 6,9 Hz, 1H), 1,39 (d, $J=6,9 \mathrm{~Hz}, 6 \mathrm{H}),{ }^{13} \mathrm{C}$ NMR $(126 \mathrm{MHz}$, Kloroform- $d$ ) $\delta 152,7,138,7,137,8,135,5,128,8,128,4$, $127,8,127,2,126,5,126,3,124,7,30,2,30,1,26,5,21,3$; HRMS (ESI) 291,1857 [M+H] ${ }^{+}$ (kalkulált: 291,1856).

\section{2-(4-Metoxifenil)-1-metil-4,5-difenil-1H-imidazol (368)}

${ }^{1} \mathrm{H}$ NMR (500 MHz, Kloroform- $d$ ) $\delta 7,67(\mathrm{~d}, J=8,7 \mathrm{~Hz}, 2 \mathrm{H}), 7,54(\mathrm{~d}, J=7,6 \mathrm{~Hz}, 2 \mathrm{H}), 7,50-$ 7,39 (m, 5H), 7,21 (t, $J=7,5 \mathrm{~Hz}, 2 \mathrm{H}), 7,14(\mathrm{t}, J=7,3 \mathrm{~Hz}, 1 \mathrm{H}), 7,02(\mathrm{~d}, J=8,7 \mathrm{~Hz}, 2 \mathrm{H}), 3,87$ $(\mathrm{s}, 3 \mathrm{H}), 3,48(\mathrm{~s}, 3 \mathrm{H}),{ }^{13} \mathrm{C}$ NMR $(126 \mathrm{MHz}$, Kloroform- $d$ ) $\delta 160,0,147,9,137,5,134,7,130,9$, 130,5, 130,1 129,0, 128,5, 128,1, 126,9, 126,3, 123,4, 114,0, 55,4, 33, 1; HRMS (ESI) 341,1651 $[\mathrm{M}+\mathrm{H}]^{+}$(kalkulált: 341,1649).

\section{1-Metil-2-(5-metilfurán-2-il)-4,5-difenil-1 $H$-imidazol (369)}

${ }^{1} \mathrm{H}$ NMR (500 MHz, Kloroform- $d$ ) $\delta$ 7,52-7,48 (m, 2H), 7,47-7,43 (m, 3H), 7,37-7,34 (m, 2H), 7,21-7,16 (m, 2H), 7,15-7,10 (m, 1H), 6,77 (d, $J=3,3 \mathrm{~Hz}, 1 \mathrm{H}), 6,14-6,11(\mathrm{~m}, 1 \mathrm{H}), 3,60$ (s, $3 \mathrm{H}), 2,40(\mathrm{~s}, 3 \mathrm{H}),{ }^{13} \mathrm{C}$ NMR (126 MHz, Kloroform-d) $\delta 153,1,143,7,139,7,137,9,134,3$, $131,0,130,7,130,0,129,1,128,7,128,0,127,1,126,4,111,1,107,6,32,7,13,8$; HRMS (ESI) $315,1493[\mathrm{M}+\mathrm{H}]^{+}$(kalkulált: 315,1492).

\section{1,2-Dimetil-4,5-difenil-1 $H$-imidazol (370)}

${ }^{1} \mathrm{H}$ NMR (500 MHz, Kloroform- $d$ ) $\delta$ 7,47 - 7,40 (m, 5H), 7,32 (d, $\left.J=7,6 \mathrm{~Hz}, 2 \mathrm{H}\right), 7,18(\mathrm{t}, J=$ $7,5 \mathrm{~Hz}, 2 \mathrm{H}), 7,11(\mathrm{t}, J=7,3 \mathrm{~Hz}, 1 \mathrm{H}), 3,37$ (s, 3H), 2,50 (s, 3H), ${ }^{13} \mathrm{C}$ NMR (126 MHz, Kloroformd) $\delta 144,7,136,2,134,7,131,4,130,9,128,9,128,9,128,4,128,1,126,7,126,1,31,1,13,6$;

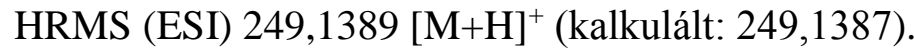

\section{2-(terc-Butil)-1-metil-4,5-difenil-1H-imidazol (371)}

${ }^{1} \mathrm{H}$ NMR (500 MHz, Kloroform- $d$ ) $\delta$ 7,48 - 7,40 (m, 5H), 7,34 - 7,30 (m, 2H), 7,16 (t, $J=7,6$ $\mathrm{Hz}, 2 \mathrm{H}), 7,08(\mathrm{t}, J=7,3 \mathrm{~Hz}, 1 \mathrm{H}), 3,51(\mathrm{~s}, 3 \mathrm{H}), 1,54(\mathrm{~s}, 9 \mathrm{H}),{ }^{13} \mathrm{C}$ NMR (126 MHz, Kloroformd) $\delta 153,9,135,1,135,0,131,7,131,2,130,2,128,9,128,4,128,0,126,7,125,8,33,6,33,2,29,5$; HRMS (ESI) 291,1858 [M+H] $]^{+}$(kalkulált: 291,1856).

\section{2-Ciklopropil-1-metil-4,5-difenil-1H-imidazol (372)}

${ }^{1} \mathrm{H}$ NMR (500 MHz, Kloroform- $d$ ) $\delta$ 7,46 - 7,38 (m, 5H), 7,34 - 7,30 (m, 2H), 7,16 (t, $J=7,8$ $\mathrm{Hz}, 2 \mathrm{H}), 7,09$ (t, $J=7,3 \mathrm{~Hz}, 1 \mathrm{H}), 3,49(\mathrm{~s}, 3 \mathrm{H}), 1,91-1,80(\mathrm{~m}, 1 \mathrm{H}), 1,20-1,10(\mathrm{~m}, 2 \mathrm{H}), 1,04$ $-0,95$ (m, 2H) ${ }^{13} \mathrm{C}$ NMR (126 MHz, Kloroform- $d$ ) $\delta$ 149,2, 135,9, 134,9, 131,4, 130,9, 128,9,

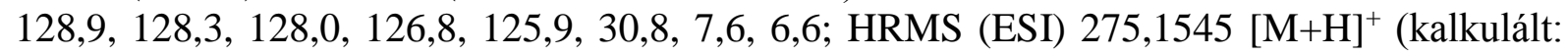
$275,1543)$. 


\section{2-Ciklohexil-1-metil-4,5-difenil-1H-imidazol (373)}

${ }^{1} \mathrm{H}$ NMR (500 MHz, Kloroform- $d$ ) $\delta$ 7,48 - 7,36 (m, 5H), 7,35 - 7,29 (m, 2H), 7,17 (t, $J=7,6$ $\mathrm{Hz}, 2 \mathrm{H}), 7,09$ (t, $J=7,3 \mathrm{~Hz}, 1 \mathrm{H}), 3,39$ (s, 3H), 2,71 (tt, $J=11,7,3,5 \mathrm{~Hz}, 1 \mathrm{H}), 2,04-1,97$ (m, $2 \mathrm{H}), 1,95-1,87(\mathrm{~m}, 2 \mathrm{H}), 1,87-1,73(\mathrm{~m}, 3 \mathrm{H}), 1,47-1,33(\mathrm{~m}, 3 \mathrm{H}),{ }^{13} \mathrm{C}$ NMR $(126 \mathrm{MHz}$, Kloroform- $d) \delta 152,2,136,4,135,2,131,6,130,9,128,9,128,4,128,2,128,0,126,9,125,9$, 77,3, 36,6, 31,6, 30,7, 26,5, 25,9; HRMS (ESI) 317,2014 [M+H] $]^{+}$(kalkulált: 317,2013).

\section{1,2-Diizopropil-4,5-difenil-1H-imidazol (374)}

${ }^{1} \mathrm{H}$ NMR (500 MHz, Kloroform- $d$ ) $\delta 7,44-7,41(\mathrm{~m}, 3 \mathrm{H}), 7,37$ (d, $\left.J=7,3 \mathrm{~Hz}, 2 \mathrm{H}\right), 7,37-7,30$ (m, 2H), 7,13 (t, $J=7,5 \mathrm{~Hz}, 2 \mathrm{H}), 7,05(\mathrm{t}, J=7,3 \mathrm{~Hz}, 1 \mathrm{H}), 4,30$ (p, $J=7,1 \mathrm{~Hz}, 1 \mathrm{H}), 3,18$ (p, $J=$ $6,8 \mathrm{~Hz}, 1 \mathrm{H}), 1,46(\mathrm{~d}, J=6,8 \mathrm{~Hz}, 6 \mathrm{H}), 1,39(\mathrm{~d}, J=7,1 \mathrm{~Hz}, 6 \mathrm{H}),{ }^{13} \mathrm{C}$ NMR $(126 \mathrm{MHz}$, Kloroformd) $\delta 152,6,136,5,135,2,132,7,131,8,128,8,128,4,127,9,127,4,126,7,125,7,47,1,27,8,22,8$, 22,6; HRMS (ESI) 305,2014 [M+H] ${ }^{+}$(kalkulált: 305,2013).

\section{1-Ciklohexil-2,4,5-trifenil-1H-imidazol (375)}

${ }^{1} \mathrm{H}$ NMR (500 MHz, Kloroform- $d$ ) $\delta$ 7,66 - 7,60 (m, 2H), 7,51 - 7,39 (m, 10H), 7,14 (t, J= 7,5 $\mathrm{Hz}, 2 \mathrm{H}), 7,08(\mathrm{t}, J=7,3 \mathrm{~Hz}, 1 \mathrm{H}), 3,97(\mathrm{tt}, J=12,3,3,5 \mathrm{~Hz}, 1 \mathrm{H}), 1,85(\mathrm{~d}, J=12,4 \mathrm{~Hz}, 2 \mathrm{H}), 1,68$ $-1,49(\mathrm{~m}, 4 \mathrm{H}), 1,45(\mathrm{~d}, J=13,5 \mathrm{~Hz}, 1 \mathrm{H}), 1,04$ (qt, $J=13,0,3,6 \mathrm{~Hz}, 2 \mathrm{H}), 0,73$ (qt, $J=13,2,3,7$ $\mathrm{Hz}, 1 \mathrm{H}),{ }^{13} \mathrm{C}$ NMR (126 MHz, Kloroform-d) $\delta$ 147,7, 137,8, 134,7, 132,6, 132,5, 132,2, 130,1, $129,1,128,9,128,8,128,7,128,4,127,9,126,7,126,0,58,4,33,6,26,2,25,1$; HRMS (ESI) 379,2168 [M+H] ${ }^{+}$(kalkulált: 379,2169).

\section{1-Benzil-2-izopropil-4,5-difenil-1H-imidazol (376)}

${ }^{1} \mathrm{H}$ NMR (500 MHz, Kloroform- $d$ ) $\delta$ 7,50 (d, $\left.J=7,1 \mathrm{~Hz}, 2 \mathrm{H}\right), 7,35-7,24$ (m, 5H), 7,24-7,16 $(\mathrm{m}, 5 \mathrm{H}), 7,11(\mathrm{~d}, J=7,3 \mathrm{~Hz}, 1 \mathrm{H}), 6,91(\mathrm{~d}, J=7,3 \mathrm{~Hz}, 2 \mathrm{H}), 4,99(\mathrm{~s}, 2 \mathrm{H}), 2,90$ (hept, $J=6,9 \mathrm{~Hz}$, $1 \mathrm{H}), 1,34(\mathrm{~d}, J=6,8 \mathrm{~Hz}, 6 \mathrm{H}),{ }^{13} \mathrm{C}$ NMR (126 MHz, Kloroform- $d$ ) $\delta 153,3,137,6,131,3,131,1$, $128,8,128,8,128,4,128,3,128,1,127,4,126,9,126,0,125,7,46,7,26,7,22,0$; HRMS (ESI) 353,2016 [M+H] ${ }^{+}$(kalkulált: 353,2013). 